\title{
Engineering Analysis for Disposal of Depleted Uranium Tetrafluoride (UF4)
}

Environmental Assessment Division Argonne National Laboratory

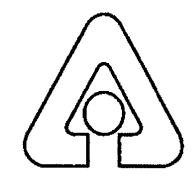

Operated by The University of Chicago, under Contract W-31-109-Eng-38, for the

United States Department of Energy 


\section{Argonne National Laboratory}

Argonne National Laboratory, with facilities in the states of Illinois and Idaho, is owned by the United States Government and operated by The University

of Chicago under the provisions of a contract with the Department of Energy.

This technical memorandum is a product of Argonne's Environmental Assessment Division (EAD). For information on the division's scientific and engineering activities, contact:

Director, Environmental Assessment Division

Argonne National Laboratory

Argonne, Illinois 60439-4832

Telephone (630) 252-3107

Presented in this technical memorandum are preliminary results of ongoing work or work that is more limited in scope and depth than that described in formal reports issued by the EAD.

Publishing support services were provided by Argonne's Information and Publishing Division (for more information, see IPD's home page: http://www.ipd.anl.gov/).

\section{Disclaimer}

This report was prepared as an account of work sponsored by an agency of the United States Government. Neither the United States Government nor any agency thereof, nor The University of Chicago, nor any of their employees or officers, makes any warranty, express or implied, or assumes any legal liability or responsibility for the accuracy, completeness, or usefulness of any information, apparatus, product, or process disclosed, or represents that its use would not infringe privately owned rights. Reference herein to any specific commercial product, process, or service by trade name, trademark, manufacturer, or otherwise does not necessarily constitute or imply its endorsement, recommendation, or favoring by the United States Government or any agency thereof. The views and opinions of document authors expressed herein do not necessarily state or reflect those of the United States Government or any agency thereof, Argonne National Laboratory, or The University of Chicago.

Available electronically at http://www.doe.gov/bridge

Available for a processing fee to U.S. Department of Energy and its contractors, in paper, from:

U.S. Department of Energy

Office of Scientific and Technical Information

P.O. Box 62

Oak Ridge, TN 37831-0062

phone: (865) 576-8401

fax: (865) $576-5728$

email: reports@adonis.osti.gov 
ANL/EAD/TM-106

\section{Engineering Analysis for Disposal of Depleted Uranium Tetrafluoride (UF4)}

by S.M. Folga and P.H. Kier*

Environmental Assessment Division

Argonne National Laboratory, 9700 South Cass Avenue, Argonne, Illinois 60439

Completed: June 2000

Published: June 2001

Work sponsored by U.S. Department of Energy, Office of Environmental Management, and Office of Site Closure-Oak Ridge Office

* Folga and Kier are affiliated with Argonne's Decision and Information Sciences Division. 
This report is printed on recycled paper. 


\section{CONTENTS}

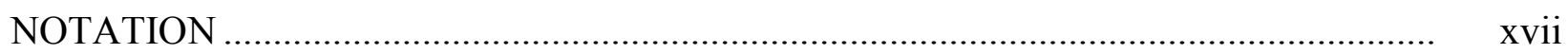

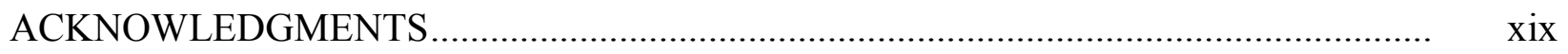

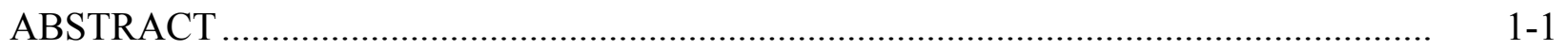

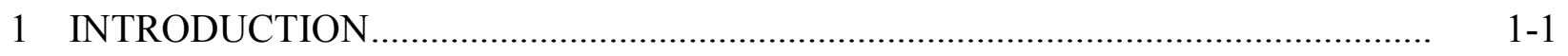

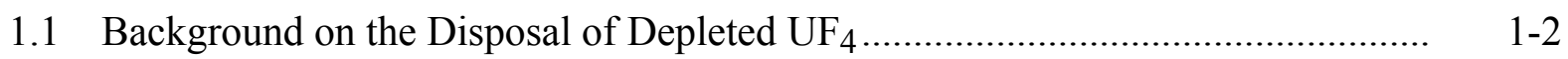

1.2 Depleted Uranium Waste Form for Disposal...................................................... 1-8

1.3 Disposal in an Engineered Trench ................................................................... $1-8$

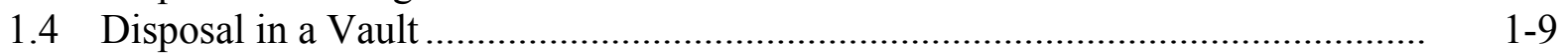

1.5 Disposal in a Mined Cavity ……………...........................................................

2 DESCRIPTION OF THE FACILITY ..................................................................... 2-1

2.1 General Design and Safety Criteria.................................................................... 2- 2-1

2.2 Engineered Trench Disposal Facility .................................................................... 2-2

2.3 Vault Disposal Facility ..................................................................................... 2-. 2-3

2.4 Mined-Cavity Disposal Facility ............................................................................... 2-. 2-4

2.5 Wasteform Facility ………………................................................................

3 DISPOSAL SITE LAND USE REQUIREMENTS ...................................................... $3-1$

3.1 Engineered Trench Disposal Facility ................................................................. 3-1

3.2 Vault Disposal Facility ........................................................................................

3.3 Mined-Cavity Disposal Facility ……………………………………………..... 3-. 3

3.4 Wasteform Facility .............................................................................................

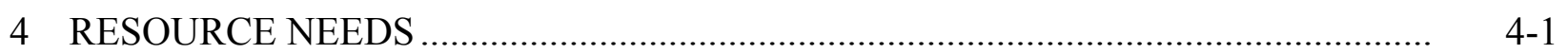

4.1 Engineered Trench Disposal Facility ...................................................................... 4- 4

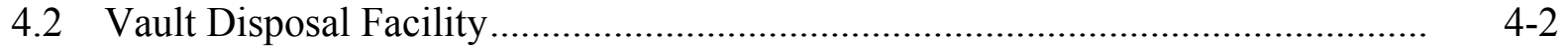

4.3 Mined-Cavity Disposal Facility ............................................................................. 4-2

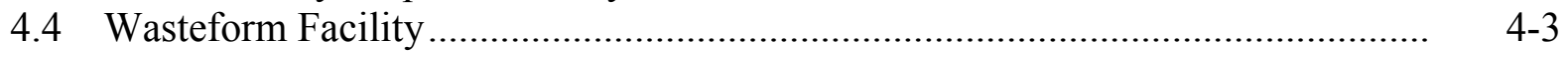

5 PERSONNEL STAFFING ESTIMATES ................................................................... 5 -1

5.1 Construction Labor Force ………………………............................................. $5-1$

5.2 Operations Labor Force................................................................................. $\quad 5-2$ 


\section{CONTENTS (Cont.)}

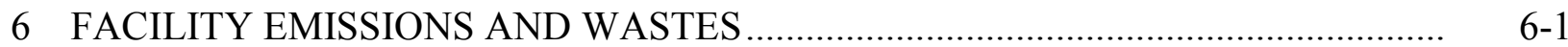

6.1 Estimates of Emissions and Wastes Generated during Construction.................... 6-1

6.2 Estimates of Emissions and Wastes Generated during Operations....................... $\quad 6-2$

7 DESCRIPTION OF POTENTIAL ACCIDENTS …................................................

7.1 Handling Accident.......................................................................................... 7-1

7.2 Fire or Explosion........................................................................................ 7-2

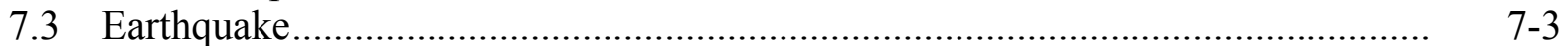

7.4 Tornado _...................................................................................

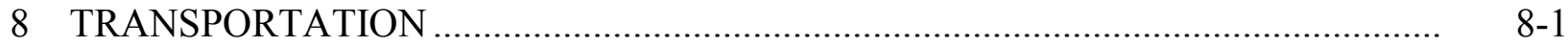

9 PERMITTING AND REGULATORY COMPLIANCE ................................................. 9-1

9.1 Commercial Disposal Facilities ………………...................................................

9.2 DOE Disposal Facilities ................................................................................. 9-6

10 PRELIMINARY SCHEDULE ESTIMATES............................................................... $10-1$

10.1 Wasteform Facility ....................................................................................... 10-2

10.2 Vault Disposal Facility ............................................................................ $10-2$

10.3 Engineered Trench Disposal Facility ............................................................... 10-3

10.4 Mined-Cavity Disposal Facility ..................................................................... 10-3

11 PARAMETRIC DATA FOR DISPOSAL IN A MINED CAVITY ................................ 11-1

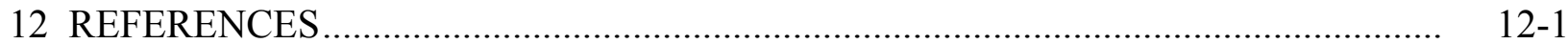

APPENDIX A: Preliminary Equipment List ................................................................ A-1

APPENDIX B: Radiation Exposure and Manpower Distribution

Estimating Data, Original and New Inventories ...................................... B- B-1

APPENDIX C: Radiation Exposure and Manpower Distribution

Estimating Data, 25\% and 50\% Cases ................................................ C-1 


\section{TABLES}

1.1 Physical Properties of Uranium Tetrafluoride

$1.2 \quad$ Characteristics of Drum Disposal Containers ……............................................... 1-11

$1.3 \quad$ Content and Number of $\mathrm{UF}_{4}$ Disposal Containers.............................................. 1-11

1.4a Area Required for Trench and Underground Mined-Cavity

Disposal, Original Inventory

1.4b Area Required for Trench and Underground Mined-Cavity Disposal,

New Inventory.

1.5a Annual Utility and Materials Requirements for Construction and Operation of an Engineered Trench Disposal Facility, Original Inventory

1.5b Annual Utility and Materials Requirements for Construction and Operation of an Engineered Trench Disposal Facility, New Inventory

1.6 Number of Disposal Vaults

1.7 Utility and Materials Requirements for Construction and Operation of the Vault Disposal Facility, One Vault.

1.8a Utility and Materials Requirements for Construction and Operation of the Mined-Cavity Disposal Facility, Original Inventory.

$1.8 \mathrm{~b}$ Utility and Materials Requirements for Construction and Operation of the Mined-Cavity Disposal Facility, New Inventory

2.1 Qualitative Assessment of Hazard Ranking for Disposal and Wasteform Facilities

2.2 Dimensions for the Engineered Trench Disposal Facility

2.3 Number of Vaults Needed for Vault Disposal Facility

2.4 Total Length of Emplacement Drifts Needed for Mined-Cavity Disposal Facility

2.5 Dimensions, Storage Configuration, and Capacity of the Product Receiving Warehouse 


\section{TABLES (Cont.)}

3.1a Site Land Parameters for Disposal of Original Inventory

in 30-Gallon Drums

3.1b Site Land Parameters for Disposal of New Inventory

in 30-Gallon Drums

3.2a Site Land Parameters for Disposal of Original Inventory

in 55-Gallon Drums

3.2b Site Land Parameters for Disposal of New Inventory

in 55-Gallon Drums

3.3 Wasteform Facility Building Footprint Areas

3.4 Site Land Parameters at the Wasteform Facility.....

4.1a Materials and Resources Required during Construction

of Engineered Trenches, Original Inventory....

4.1b Materials and Resources Required during Construction of Engineered

Trenches, New Inventory.

4.2a Resources Required during Operation of the Engineered Trench

Disposal Facility, Original Inventory.

4.2b Resources Required during Operation of the Engineered Trench

Disposal Facility, New Inventory

4.3a Materials and Resources Required during Construction of the Vault

Disposal Facility, Original Inventory.

4.3b Materials and Resources Required during Construction of the Vault

Disposal Facility, New Inventory

4.4a Resources Required during Operation of the Vault Disposal

Facility, Original Inventory

4.4b Resources Required during Operation of the Vault Disposal

Facility, New Inventory ....

4.5a Materials and Resources Required during Construction of the Mined-Cavity Facility, Original Inventory 


\section{TABLES (Cont.)}

4.5b Materials and Resources Required during Construction of the Mined-Cavity Facility, New Inventory

4.6a Resources Required during Operation of the Mined-Cavity Facility, Original Inventory.

4.6b Resources Required during Operation of the Mined-Cavity Facility, New Inventory.....

4.7a Materials and Resources Required during Construction of the Wasteform Facility, Original Inventory

4.7b Materials and Resources Required during Construction of the Wasteform Facility, New Inventory.....

4.8a Estimated Volume of Concrete Required for the Wasteform Facility,

Original Inventory.

4.8b Estimated Volume of Concrete Required for the Wasteform Facility,

New Inventory

4.9a Resources Required during Operation of the Wasteform Facility,

Original Inventory....

4.9b Resources Required during Operation of the Wasteform Facility,

New Inventory.....

5.1a Summary of Construction Labor Estimates, Original Inventory...

5.1b Summary of Construction Labor Estimates, New Inventory

5.2a Number of Construction Workers Needed by Year for the Wasteform

Facility, Original Inventory.

5.2b Number of Construction Workers Needed by Year for the Wasteform

Facility, New Inventory

5.3a Number of Construction Workers Needed by Year for Mined-Cavity

Disposal Facility, Original Inventory...

5.3b Number of Construction Workers Needed by Year for Mined-Cavity Disposal Facility, New Inventory 


\section{TABLES (Cont.)}

5.4a Summary of Operational Labor Estimates, Original Inventory .......................... $\quad 5-5$

5.4b Summary of Operational Labor Estimates, New Inventory $\quad$............................... $5-6$

6.1 National Ambient Air Quality Standards for Criteria Air Pollutants.................... 6-3

6.2 Estimated Emissions and Wastes from Construction of Trench

Disposal Facility ................................................................................

6.3 Estimated Emissions and Wastes from Construction of Vault

Disposal Facility ....................................................................................

6.4 Estimated Emissions and Wastes from Construction of Mined-Cavity

Disposal Facility ..................................................................................

6.5 Estimated Emissions and Wastes from Construction

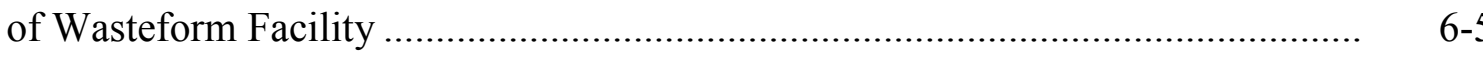

6.6a Estimated Average Annual Emissions from Operation of Disposal

Facilities, Original Inventory .......................................................................

6.6b Estimated Average Annual Emissions from Operation of Disposal

Facilities, New Inventory ................................................................................. 6

6.7a Estimated Annual Emissions and Wastes from Operation of

the Wasteform Facility, Original Inventory ...................................................

6.7b Estimated Annual Emissions and Wastes from Operation of the Wasteform Facility, New Inventory ..................................................... $6-7$

7.1 Assessment of Accidents ......................................................................

8.1a Off-Site Transport of Supplies and Input Materials for the Wasteform Facility, Original Inventory .................................................. $8-2$

8.1b Off-Site Transport of Supplies and Input Materials for the Wasteform Facility, New Inventory ........................................................... $8-3$

11.1a Annual Input/Output Summary, 30-Gallon Drums........................................ 11-3

11.1b Annual Input/Output Summary, 55-Gallon Drums........................................ 11-3

11.2a Land Use Requirements for Wasteform Facility, 30-Gallon Drums .................... 11-4 


\section{TABLES (Cont.)}

11.2b Land Use Requirements for Wasteform Facility, 55-Gallon Drums ...................... 11-4

11.3a Land Use Requirements for Mined-Cavity Disposal Area,

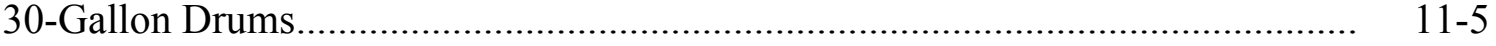

11.3b Land Use Requirements for Mined-Cavity Disposal Area, 55-Gallon Drums........................................................................................... 11-6

11.4a Construction Resources, 30-Gallon Drums ………................................................. 11-7

11.4b Construction Resources, 55-Gallon Drums ………............................................. 11-7

11.5a Operations Resources, 30-Gallon Drums............................................................ 11-8

11.5b Operations Resources, 55-Gallon Drums........................................................... 11-8

11.6a Employment, 30-Gallon Drums ............................................................... 11-8

11.6b Employment, 55-Gallon Drums ...................................................................... 11-9

11.7a Construction Emissions and Wastes, Mined-Cavity Disposal Facility, 30-Gallon Drums ................................................................................ 11-9

11.7b Construction Emissions and Wastes, Mined-Cavity Disposal Facility, 55-Gallon Drums ......................................................................... 11-10

11.8a Construction Emissions and Wastes, Wasteform Facility, 30-Gallon Drums.

11.8b Construction Emissions and Wastes, Wasteform Facility, 55-Gallon Drums.

11.9 Operations Emissions and Wastes, Mined-Cavity Disposal Facility ...................... 11-11

11.10a Annual Emissions and Wastes, Wasteform Facility, 30-Gallon Drums .................. 11-12

11.10b Annual Emissions and Wastes, Wasteform Facility, 55-Gallon Drums ................. 11-12

11.11a Transportation Summary, 30-Gallon Drums …………………………….......... 11-13

11.11b Transportation Summary, 55-Gallon Drums …………………………............. 11-13 


\section{TABLES (Cont.)}

11.12a Number of Construction Workers Needed by Year for Mined-Cavity

Disposal Facility, 100\% Case

11.12b Number of Construction Workers Needed by Year for Mined-Cavity

Disposal Facility, 50\% Case

11.12c Number of Construction Workers Needed by Year for Mined-Cavity

Disposal Facility, 25\% Case

11.13a Number of Construction Workers Needed by Year for the Wasteform

Facility, 100\% Case

11.13b Number of Construction Workers Needed by Year for the Wasteform

Facility, 50\% Case

11.13c Number of Construction Workers Needed by Year for the Wasteform

Facility, 25\% Case

A.1 Preliminary Equipment List for the Administration Building

A.2 Preliminary Equipment List for the Product Receiving and Shipping Warehouse

A.3 Preliminary Equipment List for the Engineered Trench Disposal Facility

A.4 Preliminary Equipment List for the Vault Disposal Facility

A.5 Preliminary Equipment List for the Mined-Cavity Disposal Facility

B.1 Vault Disposal Facility: Operational Activities,

Original Inventory - 30-Gallon Drums.

B.2 Vault Disposal Facility: Maintenance Activities,

Original Inventory - 30-Gallon Drums.

B.3 Engineered Trench Disposal Facility: Operational Activities, Original Inventory - 30-Gallon Drums.

B.4 Engineered Trench Disposal Facility: Maintenance Activities,

Original Inventory - 30-Gallon Drums.

B.5 Mined-Cavity Disposal Facility: Operational Activities, Original Inventory - 30-Gallon Drum 


\section{TABLES (Cont.)}

B.6 Mined-Cavity Disposal Facility: Maintenance Activities,

Original Inventory - 30-Gallon Drums

B.7 Vault Disposal Facility: Operational Activities,

Original Inventory - 55-Gallon Drums.

B.8 Vault Disposal Facility: Maintenance Activities,

Original Inventory - 55-Gallon Drums

B-10

B.9 Engineered Trench Disposal Facility: Operational Activities,

Original Inventory - 55-Gallon Drums.

B-11

B.10 Engineered Trench Disposal Facility: Maintenance Activities,

Original Inventory - 55-Gallon Drums.

B.11 Mined-Cavity Disposal Facility: Operational Activities,

Original Inventory - 55-Gallon Drums.

B.12 Mined-Cavity Disposal Facility: Maintenance Activities,

Original Inventory - 55-Gallon Drums.

B-14

B.13 Vault Disposal Facility: Operational Activities,

New Inventory - 30-Gallon Drums

B-15

B.14 Vault Disposal Facility: Maintenance Activities,

New Inventory - 30-Gallon Drums

B-16

B.15 Engineered Trench Disposal Facility: Operational Activities,

New Inventory - 30-Gallon Drums

B.16 Engineered Trench Disposal Facility: Maintenance Activities,

New Inventory - 30-Gallon Drums

B-18

B.17 Mined-Cavity Disposal Facility: Operational Activities,

New Inventory - 30-Gallon Drums

B.18 Mined-Cavity Disposal Facility: Maintenance Activities,

New Inventory - 30-Gallon Drums

B.19 Vault Disposal Facility: Operational Activities,

New Inventory - 55 Gallon Drums

B.20 Vault Disposal Facility: Maintenance Activities, New Inventory

B-22 


\section{TABLES (Cont.)}

B.21 Engineered Trench Disposal Facility: Operational Activities,

New Inventory.....

B.22 Engineered Trench Disposal Facility: Maintenance Activities,

New Inventory.

B.23 Mined-Cavity Disposal Facility: Operational Activities, New Inventory

B.24 Mined-Cavity Disposal Facility: Maintenance Activities, New Inventory..

B-26

C.1 Mined-Cavity Disposal Facility: Operational Activities, $50 \%$ of Original Inventory - 30-Gallon Drums

C.2 Mined-Cavity Disposal Facility: Maintenance Activities, $50 \%$ of Original Inventory - 30-Gallon Drums

C.3 Mined-Cavity Disposal Facility: Operational Activities, $50 \%$ of Original Inventory - 55-Gallon Drums.

C.4 Mined-Cavity Disposal Facility: Maintenance Activities, $50 \%$ of Original Inventory - 55-Gallon Drums

C.5 Mined-Cavity Disposal Facility: Operational Activities, $25 \%$ of Original Inventory - 30-Gallon Drums

C.6 Mined-Cavity Disposal Facility: Maintenance Activities, $25 \%$ of Original Inventory - 30-Gallon Drums

C.7 Mined-Cavity Disposal Facility: Operational Activities, $25 \%$ of Original Inventory - 55-Gallon Drums .

C.8 Mined-Cavity Disposal Facility: Maintenance Activities, $25 \%$ of Original Inventory - 55-Gallon Drums

C-10

\section{FIGURES}

1.1a Material Flow Diagram, Old Inventory …………….......................................... 1-16

1.1b Material Flow Diagram, New Inventory .............................................................. 1-16 


\section{FIGURES (Cont.)}

1.2a Wasteform Facility Process Flow Diagram for Construction:

New Inventory, 30-Gallon Drums

1.2b Wasteform Facility Process Flow Diagram for Construction:

New Inventory, 55-Gallon Drums ................................................................. 1-18

1.3a Wasteform Facility Process Flow Diagram for Operations:

New Inventory, 30-Gallon Drums …………………..................................... 1-19

1.3b Wasteform Facility Process Flow Diagram for Operations:

New Inventory, 55-Gallon Drums ................................................................. 1-20

1.4a Trench Disposal Facility Process Flow Diagram for Construction:

New Inventory, 30-Gallon Drums ................................................................. 1-21

1.4b Trench Disposal Facility Process Flow Diagram for Construction:

New Inventory, 55-Gallon Drums

1.5a Trench Disposal Facility Process Flow Diagram for Operations:

New Inventory, 30-Gallon Drums .................................................................. 1-23

1.5b Trench Disposal Facility Process Flow Diagram for Operations:

New Inventory, 55-Gallon Drums

1.6a Vault Disposal Facility Process Flow Diagram for Construction:

New Inventory, 30-Gallon Drums

1.6b Vault Disposal Facility Process Flow Diagram for Construction:

New Inventory, 55-Gallon Drums

1.7a Vault Disposal Facility Process Flow Diagram for Operations:

New Inventory, 30-Gallon Drums

1.7b Vault Disposal Facility Process Flow Diagram for Operations:

New Inventory, 55-Gallon Drums

1.8a Mined-Cavity Disposal Facility Process Flow Diagram for Construction:

New Inventory, 30-Gallon Drums

1.8b Mined-Cavity Disposal Facility Process Flow Diagram for Construction:

New Inventory, 55-Gallon Drums 


\section{FIGURES (Cont.)}

1.9a Mined-Cavity Disposal Facility Process Flow Diagram for Operations:

New Inventory, 30-Gallon Drums

1.9b Mined-Cavity Disposal Facility Process Flow Diagram for Operations:

New Inventory, 55-Gallon Drums

3.1a Site Map and Land Area for Operation of the Engineered Trench

Disposal Facility: New Inventory, 30-Gallon Drums

3.1b Site Map and Land Area for Operation of the Engineered Trench

Disposal Facility: New Inventory, 55-Gallon Drums

3.2a Site Map for Construction of the Vault Disposal Facility:

New Inventory, 30-Gallon Drums

3.2b Site Map for Construction of the Vault Disposal Facility:

New Inventory, 55-Gallon Drums

3.3a Site Map and Land Area during Operation of the Mined-Cavity

Disposal Facility: New Inventory, 30-Gallon Drums

3.3b Site Map and Land Area during Operation of the Mined-Cavity

Disposal Facility: New Inventory, 55-Gallon Drums

3.4a Site Map during Operation of the Wasteform Facility:

New Inventory, 30-Gallon Drums

3.4b Site Map during Operation of the Wasteform Facility:

New Inventory, 55-Gallon Drums

10.1 Estimated Overall Schedule for the Depleted UF $_{4}$ Disposal Program,

New Inventory, Vault and Engineered Trench Disposal Options.

10.2 Estimated Overall Schedule for the Depleted $\mathrm{UF}_{4}$ Disposal Program,

New Inventory, Mined-Cavity Option

11.1a Wasteform Facility Footprint for $100 \%, 50 \%$, and $25 \%$ of

Original Inventory, 30-Gallon Drums

11.1b Wasteform Facility Footprint for 100\%, 50\%, and 25\% of

Original Inventory, 55-Gallon Drums. 


\section{FIGURES (Cont.)}

11.2a Mined-Cavity Underground Footprint for $100 \%, 50 \%$, and $25 \%$ of

Original Inventory, 30-Gallon Drums......................................................... 11-19

11.2b Mined-Cavity Underground Footprint for $100 \%, 50 \%$, and $25 \%$ of

Original Inventory, 55-Gallon Drums....

11.3a Mined-Cavity Disposal Facility Footprint at 100\% of

Original Inventory, 30-Gallon Drums

11.3b Mined-Cavity Disposal Facility Footprint at $100 \%$ of

Original Inventory, 55-Gallon Drums.

11.4a Mined-Cavity Disposal Facility Footprint at 50\% of

Original Inventory, 30-Gallon Drums.

11.4b Mined-Cavity Disposal Facility Footprint at 50\% of

Original Inventory, 55-Gallon Drums

11.5a Mined-Cavity Disposal Facility Footprint at 25\% of

Original Inventory, 30-Gallon Drums.

11.5b Mined-Cavity Disposal Facility Footprint at 25\% of

Original Inventory, 55-Gallon Drums

$11-26$ 


\section{NOTATION}

The following is a list of the abbreviations, acronyms, and units of measure used in this report.

\section{ABBREVIATIONS AND ACRONYMS}

ALARA as low as reasonably achievable

CFR Code of Federal Regulations

$\mathrm{CH}_{4} \quad$ methane

$\mathrm{CO} \quad$ carbon monoxide

DF damage fraction

DOE U.S. Department of Energy

DOE-HDBK U.S. Department of Energy Handbook

DOE-STD U.S. Department of Energy Standard

DOT U.S. Department of Transportation

EIS environmental impact statement

EPA U.S. Environmental Protection Agency

FEMP Fernald Environmental Management Project

FTE full-time equivalent

HEPA high-efficiency particulate air

HF hydrogen fluoride

HVAC heating, ventilation, and air-conditioning

LLMW low-level mixed waste

LLNL Lawrence Livermore National Laboratory

LLW low-level radioactive waste

LLWPAA Low-Level Radioactive Waste Policy Amendments Act of 1985

LPF leak path factor

MAR material at risk

MC\&A material control and accountability

MPFL maximum possible fire loss

NAAQS National Ambient Air Quality Standards

NEPA National Environmental Policy Act

NFPA National Fire Protection Association

NMHC nonmethane hydrocarbons

$\mathrm{NO}_{\mathrm{x}} \quad$ nitrogen oxides 


\begin{tabular}{|c|c|}
\hline NPH & natural phenomena hazard \\
\hline NRC & U.S. Nuclear Regulatory Commission \\
\hline NTS & Nevada Test Site \\
\hline NTSWAC & Nevada Test Site Waste Acceptance Criteria \\
\hline NV & Nevada Operations Office (DOE) \\
\hline OSHA & Occupational Safety and Health Administration \\
\hline PA & performance assessment \\
\hline $\mathrm{PM}_{10}$ & particulate matter with a diameter of less than or equal to 10 micrometers \\
\hline RARF & respirable airborne release fraction \\
\hline ROD & Record of Decision \\
\hline $\mathrm{SO}_{2}$ & sulfur dioxide \\
\hline SSCs & structures, systems, and components \\
\hline TEDE & total effective dose equivalent \\
\hline $\mathrm{U}$ & uranium \\
\hline $\mathrm{UF}_{4}$ & uranium tetrafluoride \\
\hline $\mathrm{UF}_{6}$ & uranium hexafluoride \\
\hline $\mathrm{UO}_{2}$ & uranium dioxide \\
\hline $\mathrm{U}_{3} \mathrm{O}_{8}$ & tiuranium octaoxide \\
\hline USEC & United States Enrichment Corporation \\
\hline WAC & waste acceptance criteria \\
\hline
\end{tabular}

\section{UNITS OF MEASURE}

$\begin{array}{ll}\mathrm{Bq} & \text { becquerel(s) } \\ \mathrm{Btu} & \text { British thermal unit(s) } \\ { }^{\circ} \mathrm{C} & \text { degree(s) Celsius } \\ \mathrm{cfm} & \text { cubic foot (feet) per meter } \\ \mathrm{Ci} & \text { curie(s) } \\ \mathrm{cm} & \text { centimeter(s) } \\ \mathrm{cm}^{3} & \text { cubic centimeter(s) } \\ { }^{\circ} \mathrm{F} & \text { degree(s) Fahrenheit } \\ \mathrm{ft} & \text { foot (feet) } \\ \mathrm{ft}^{2} & \text { square foot (feet) } \\ \mathrm{g} & \text { gram(s) } \\ \mathrm{h} & \text { hour(s) } \\ \mathrm{ha} & \text { hectare(s) } \\ \mathrm{in} . & \text { inch(es) } \\ \mathrm{kg} & \text { kilogram(s) }\end{array}$

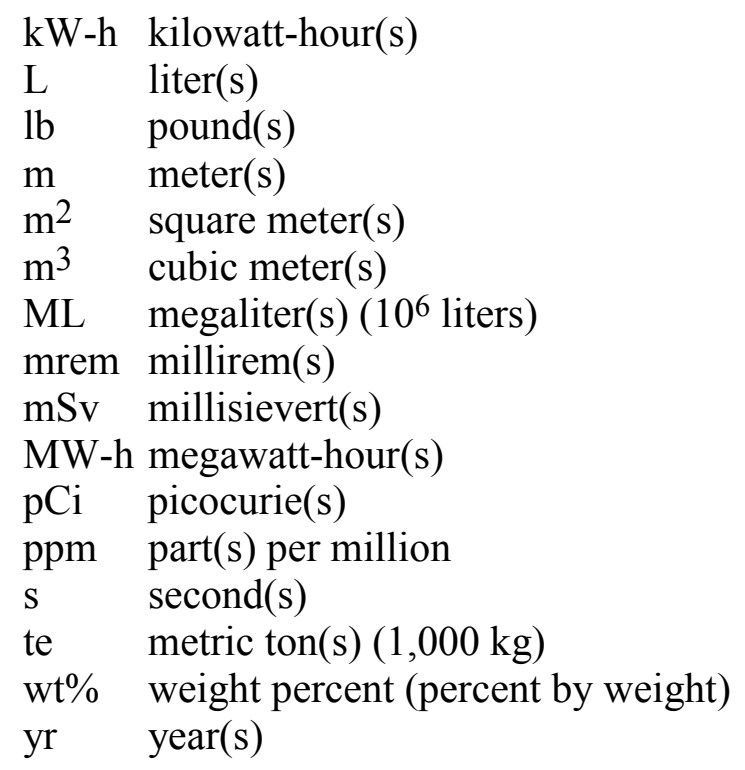




\section{ACKNOWLEDGMENTS}

The assistance of John Sattler, Director of Waste Management at the U.S. Department of Energy Fernald Environmental Management Project (FEMP), and Rebecca Guertaf, HAZMAT

Project Manager at the Nevada Test Site (NTS), in providing information about past disposal of depleted $\mathrm{UF}_{4}$ from FEMP at NTS is gratefully acknowledged. 


\title{
ENGINEERING ANALYSIS FOR DISPOSAL OF DEPLETED URANIUM TETRAFLUORIDE $\left(\mathrm{UF}_{4}\right)$
}

\author{
by S.M. Folga and P.H. Kier
}

\begin{abstract}
This report presents and evaluates options for disposing of depleted uranium in the chemical form of uranium tetrafluoride $\left(\mathrm{UF}_{4}\right)$. Two depleted uranium inventories are considered. One results from the original U.S. Department of Energy (DOE) inventory of 560,000 metric tons (te) of depleted uranium hexafluoride $\left(\mathrm{UF}_{6}\right)$; the other inventory is the original DOE inventory augmented by 145,000 te of depleted $\mathrm{UF}_{6}$ from the United States Enrichment Corporation. Preconceptual designs are included for three disposal options: disposal in a vault, disposal in an engineered trench, and disposal in a deep mine cavity. The disposal container is taken to be either a 30-gallon drum or a 55-gallon drum. Descriptions of the facilities associated with the three disposal options are provided. Staffing estimates for the construction and operation of the facilities are also provided. Wastes and emissions from the facilities during construction, operation, and maintenance have been estimated. Parametric studies have also been performed on the basis of $25 \%$ and $50 \%$ of the original inventory.
\end{abstract}

\section{INTRODUCTION}

A number of options for the long-term management of depleted uranium hexafluoride $\left(\mathrm{UF}_{6}\right)$ have been assessed by the U.S. Department of Energy (DOE) in the Depleted Uranium Management Program; the Engineering Analysis Report for the Long-Term Management of Depleted Uranium Hexafluoride (LLNL et al. 1997) and the Programmatic Environmental Impact Statement for Alternative Strategies for the Long-Term Management and Use of Depleted Uranium Hexafluoride (DOE 1999a). These options included several choices for the chemical form of depleted uranium to be disposed of and three types of disposal facilities. The chemical forms specifically analyzed in the 1997 report were uranium dioxide $\left(\mathrm{UO}_{2}\right)$ and triuranium octaoxide $\left(\mathrm{U}_{3} \mathrm{O}_{8}\right)$. The types of disposal facilities considered were engineered trenches, vaults, and deep mined cavities.

This report addresses disposal of an additional chemical form, namely, uranium tetrafluoride $\left(\mathrm{UF}_{4}\right)$. The 1997 LLNL et al. report documenting the engineering analyses for disposal of the other two chemical forms will be referred to here as the Engineering Analysis Report. Section 6.13 of the Engineering Analysis Report addresses the disposal options for the other chemical forms. To help ensure fair treatment of all options, the same assumptions were used in this report as in the Engineering Analysis Report to the extent possible. When different assumptions are made, they are discussed. Also, to assist in comparison of the options in 
Section 6.13 with the option analyzed here for disposal of depleted $\mathrm{UF}_{4}$, the table of contents, the figures, and the tables in this report are comparable to those in the Engineering Analysis Report, Section 6.13 .

\subsection{BACKGROUND ON THE DISPOSAL OF DEPLETED UF 4}

For the purposes of this study, depleted uranium in the chemical form of uranium tetrafluoride $\left(\mathrm{UF}_{4}\right)$ is assumed to be produced at a site other than the disposal facility and is transported to the disposal facility by truck or rail. It is also assumed that the depleted UF 4 would be placed in disposal containers that are suitable for transportation.

\subsubsection{Disposal Area Required}

The area required for disposal depends on four factors: (1) the weight percent of uranium in the compound disposed of, (2) the bulk density of the compound disposed of, (3) the type of disposal container used, and (4) the type of disposal units used (engineered trenches, vaults, mined cavities). Depleted $\mathrm{UF}_{4}$ is a solid composed of agglomerating particles with a texture similar to baking soda. It is nonvolatile, nonhydroscopic, but only slightly soluble in water ( $\sim 40 \mathrm{ppm}$ at room temperature) (Katz et al. 1986). It has a particle density of $6.5 \mathrm{~g} / \mathrm{cm}^{3}$; however, its bulk density, which depends on production process and the properties of the starting uranium compounds, ranges between 2.0 and $4.5 \mathrm{~g} / \mathrm{cm}^{3}$. To be consistent with the accident analysis in the Engineering Analysis Report in which a spill of a 55-gallon drum containing $\mathrm{UF}_{4}$ is considered, the bulk density of $\mathrm{UF}_{4}$ is taken as $3.2 \mathrm{~g} / \mathrm{cm}^{3}$.

The physical properties of $\mathrm{UF}_{4}$ are given in Table 1.1.1 Because of the difference between the particle density and the bulk density, $\mathrm{UF}_{4}$ itself does not have structural stability.

It is assumed in this analysis that the potential evolution of fluoride ions due to chemisorbed hydrogen fluoride (HF) would be removed during the conversion process by heating the depleted $\mathrm{UF}_{4}$ product before it is placed in drums.

Depleted $\mathrm{UF}_{4}$ reacts very slowly with moisture at ambient temperature to form depleted $\mathrm{UO}_{2}$ and $\mathrm{HF}$, which would enhance the corrosion rate of the disposal packages. This analysis assumes that drum filling during the conversion process would be performed under inert conditions to exclude airborne moisture.

\footnotetext{
${ }^{1}$ For reader convenience, tables and figures referred to in Section 1 are placed at the end of the section.
} 
One potential issue is the reactivity of depleted $\mathrm{UF}_{4}$ in bulk form. Croff et al. (2000) state that the low solubility of depleted $\mathrm{UF}_{4}$ in water would result in a reaction rate low enough to consider the material to be not "reactive" as the term is generally interpreted in waste management.

Historically, approximately 1,870 te of depleted $\mathrm{UF}_{4}$ in the form of salts, residues, and dust has been shipped from the U.S. DOE Fernald Environmental Management Project (FEMP) to the U.S. DOE Nevada Test Site (NTS) for disposal (Croff et al. 2000). The material was disposed of in white metal boxes $(1.2 \times 1.2 \times 2.1 \mathrm{~m}[4 \times 4 \times 7 \mathrm{ft}])$ without any additional overpacking (Guertaf 2000a). The bulk depleted $\mathrm{UF}_{4}$ from the FEMP was not treated before disposal at the NTS.

A review of the properties of the depleted $\mathrm{UF}_{4}$ in bulk form by the FEMP and NTS prior to shipment to the NTS did not reveal any major issues associated with reactivity (Guertaf 2000a; Sattler 2000). It was demonstrated that the reaction rate was slow enough that the Nevada Test Site Waste Acceptance Criteria and U.S. Department of Transportation (DOT) requirements were met. A position paper was issued by the FEMP before these shipments began (Guertaf 2000 b). However, it should still be demonstrated that depleted $\mathrm{UF}_{4}$ produced in the future can be safely shipped; additional packaging costs or extended reviews of the waste program or waste stream profile may be required (Croff et al. 2000). Because of the speculative nature of the overpacking or review process, they were not considered further in this analysis.

Because $\mathrm{UF}_{4}$ forms a corrosive product in the presence of water, it is not suitable for grouting. Furthermore, it cannot be vitrified and still be disposed of as $\mathrm{UF}_{4}$ because vitrification would oxidize $\mathrm{UF}_{4}$ to become an oxide containing $\mathrm{UO}_{2}$ and $\mathrm{U}_{3} \mathrm{O}_{8}$. Macroencapsulation using molten polyethylene had been considered as a potential treatment option for depleted $\mathrm{UF}_{4}$ shipped from the FEMP to the NTS for disposal; however, treatment of the FEMP's depleted $\mathrm{UF}_{4}$ was considered unnecessary for disposal at the NTS. Therefore, it is assumed that $\mathrm{UF}_{4}$ is not processed to achieve a stable waste form. However, it is not required that a disposal waste form be stable if it is Class A waste under NRC's classification scheme, and depleted UF 4 is Class A waste. All that is required is that waste must have structural stability (i.e., maintain its physical dimensions and its form) under expected disposal conditions (such as weight of the overburden and compaction equipment, the presence of moisture, and microbial activity) and expected internal factors (such as radiation effects and chemical changes). Structural stability can also be achieved by placing the waste in a disposal container and a structure that provide stability after disposal (Title 10, Code of Federal Regulations, Part 61.56(b) [10 CFR 61.56(b)]). It is assumed here that $\mathrm{UF}_{4}$ is disposed of in strong 30 -gallon or 55-gallon drums. ${ }^{2}$ It is also assumed that the disposal container and the disposal facility provide structural stability.

\footnotetext{
2 The metric equivalents of 30 and 55 gallons are approximately 114 and 208 liters, respectively. Since these drums are more commonly referred to by their standard unit volumes, they will be called 30-gallon and 55-gallon drums in this report.
} 
In the Engineering Analysis Report, 30-gallon drums with a wall thickness of $0.241 \mathrm{~cm}$ (0.095 in.) and weighing $45.4 \mathrm{~kg}(100 \mathrm{lb})$ were used for the disposal of $\mathrm{UO}_{2}$, and 55-gallon drums with a wall thickness of $0.135 \mathrm{~cm}\left(0.053 \mathrm{in}\right.$.) were used for the disposal of $\mathrm{U}_{3} \mathrm{O}_{8}$. It is assumed that drums with the same specifications would be used for the disposal of $\mathrm{UF}_{4}$ (see Table 1.2). $\mathrm{UF}_{4}$ is made directly from the conversion of $\mathrm{UF}_{6}$. The DOE inventory of $\mathrm{UF}_{6}$ considered in the Engineering Analysis Report was 560,000 te. This inventory converts to approximately 500,000 te of $\mathrm{UF}_{4}$. Thus, with the assumed bulk density of $3.2 \mathrm{~g} / \mathrm{cm}^{3}, 1,373,000$ 30 -gallon drums would be needed for its disposal. These drums would be shipped at the rate of 68,650 drums per year over a 20-year period. Alternatively, 749,000 55-gallon drums (or 37,450 drums per year) would be needed.

At the time the Engineering Analysis Report was written, the inventory of depleted $\mathrm{UF}_{6}$ that fell under the responsibility of DOE was 560,000 te stored in 56,422 cylinders. Since then, two memoranda of agreement have been signed between DOE and the United States Enrichment Corporation (USEC) that have or will result in the transfer of 145,000 te of depleted $\mathrm{UF}_{6}$ in approximately 11,200 cylinders from USEC to DOE (DOE 1999b). This transfer increases the inventory of the material that falls under DOE's management responsibility to approximately 705,000 te in about 57,700 cylinders. This report addresses the disposal of both the original inventory and the new inventory of depleted $\mathrm{UF}_{6}$ after it has been converted to $\mathrm{UF}_{4}$. The original inventory is included mainly to facilitate comparison with the Engineering Analysis Report. The new inventory converts to approximately 630,000 te of $\mathrm{UF}_{4}$. Disposal of the new inventory would require 1,728,000 30-gallon drums or 943,000 55-gallon drums (Table 1.3).

An arid climate provides the most favorable conditions for disposal of depleted uranium. A specific arid location for the disposal facility, which could be a DOE facility or a commercial facility operating under a radioactive materials license issued by the U.S. Nuclear Regulatory Commission (NRC) or an Agreement State, will be determined at a later date. To identify whether there might be issues associated with the disposal of depleted $\mathrm{UF}_{4}$, questions of conformity to the waste acceptance criteria (WAC) of a DOE disposal facility and to the conditions of the radioactive material license of a commercial facility are considered. For the purposes of this report, the waste acceptance criteria for the NTS (DOE 1999c) and the radioactive materials license conditions for the Envirocare facility in Clive, Utah (Utah Department of Environmental Quality 2000), are considered to be typical of disposal requirements in an arid climate.

The current waste acceptance criteria at NTS limit the weight of a drum to $544 \mathrm{~kg}$. As discussed in Section 9, a 30-gallon drum fully loaded with $\mathrm{UF}_{4}$ would comply with this limitation, while a fully loaded 55 -gallon drum $(665 \mathrm{~kg}$, or $1,466 \mathrm{lb})$ would not. This limitation in the WAC is apparently based on an Occupational Safety and Health Administration regulation regarding the loading of hoists as applied to forklifts currently in use at NTS. The Engineering Analysis Report, which considered an earlier set of waste acceptance criteria at NTS, allowed disposal of $625 \mathrm{~kg}(1,378 \mathrm{lb})$ of $\mathrm{U}_{3} \mathrm{O}_{8}$ in 55-gallon drums. The radioactive material license for the Envirocare disposal facility does not limit the weight of disposal containers. Disposal of UF 4 
in 55-gallon drums may be cost-effective for some disposal options. Also, the weight limit on drums at NTS does not have a radiological basis. Use of stronger forklifts at a depleted $\mathrm{UF}_{4}$ disposal facility at NTS might remove this limitation. Therefore, the option of disposal in 55-gallon drums is presented in this report.

\subsubsection{Other Considerations}

The primary concerns for disposal of $\mathrm{UF}_{4}$, as for other radioactive wastes, are to isolate the waste from the environment for as long as possible, to ensure that if or when engineered barriers have lost effectiveness that standards for the protection of the general public are met, and that after institutional control over the disposal facility has ended, inadvertent intruders will not be harmed. To ensure that these performance objectives are met, both DOE and NRC or Agreement States require detailed analyses, called performance assessments, of the potential radiological dose to the public following closure of the disposal facility. DOE in DOE M 435.1-1, Radioactive Waste Management Manual, requires a performance assessment that covers a 1,000-year period after closure. It is beyond the scope of an engineering analysis to estimate radiological dose to the general public or an inadvertent intruder following closure of a disposal facility. However, such analyses would be conducted under the National Environmental Policy Act (NEPA).

\subsubsection{Safety and Safeguards}

DOE M 435.1-1, Radioactive Waste Management Manual, requires that appropriate features be incorporated into the design and operation of radioactive waste management facilities, operations, and activities to prevent unauthorized access and operations, and for purposes of nuclear material control and accountability, where applicable. These features are to be consistent with DOE O 470.1, Safety and Security Program.

DOE O 470.1 requires that certain facilities have a safeguards and security program. Such facilities include "Those that have a radiological/toxicological sabotage threat that would cause a unacceptable impact on the national security, the health and safety of employees, the public or the environment." Persons entering the disposal facility with sabotage or another malevolent intent could cause drums to be damaged or cause explosions that could damage engineered trenches, vaults, or access to mined cavities. Hence, the health and safety of employees and the public, or the environment, could be threatened; therefore, a safeguards and security program would be needed. Because the disposal facility will not contain special nuclear material nor classified matter, DOE intends that a graded approach be used so that the "magnitude of the resources expended are commensurate with the security interest's importance and the impact of the loss, destruction, misuse." 
It is beyond the scope of an engineering analysis to address details of a safeguards and security plan except how it would affect the equipment required (Appendix A) and the data used to estimate radiation exposure and staffing (Appendix B). It was assumed that security personnel would be assigned to the product receiving and shipping warehouse, the administration building, a disposal unit, and key areas of the site (e.g., entry point); that all persons when on-site would be issued security badges that would have location indicators that would be monitored by security personnel; and that the receiving warehouse and repackaging building would have an automated security station to control access. Security surveillance and alarm systems (e.g., closed circuit television, remote operated locked barriers) would be included, as appropriate. Site security fencing could consist of galvanized steel fabric fencing with barbed wire or barbed wire coil topping. The fence would limit access into the site to a single road where a guard station would be located at the boundary of the site. Perimeter fence lighting particulars will be determined by security and safeguards requirements. Full-time security and emergency staff could provide immediate aid in the event of any security breach or environmental incident.

\subsubsection{Fire Protection}

DOE O 420.1, Facility Safety, Section 4.2, establishes requirements for a comprehensive protection program to minimize the likelihood of the occurrence of a fire or related event and to minimize adverse impacts should a fire or related event occur. Acceptance methods for facility fire protection are contained in DOE Standard DOE-STD-1066-97, Fire Protection Design Criteria (DOE 1997), and the DOE Fire Protection Handbook, DOE-HDBK-1062-96 (DOE 1996). These requirements replace certain mandatory fire protection requirements that were formerly stipulated in DOE Order 5480.7A, Fire Protection, and DOE Order 6430.1A, General Design Criteria. Supplemental fire protection guidance applicable to the design and construction of DOE facilities and site features (such as water distribution systems) is provided. This guidance is intended to be used in conjunction with the application building code, National Fire Protection Association (NFPA) Codes and Standards, and any other applicable construction criteria.

DOE Standard DOE-STD-1066-97 states in Section 5.2 that new permanent structures in excess of $5,000 \mathrm{ft}^{2}\left(465 \mathrm{~m}^{2}\right)$ in floor area should be of noncombustible or fire resistive construction if no local building code is enforced. The three long-term storage options for depleted uranium metal (i.e., building, vault, mined cavity) would meet this structural requirement.

In addition, DOE Standard DOE-STD-1066-97 states in Section 5.3 that all facilities of significance, including facilities where a fire could cause unacceptable off-site consequences to health and safety, should be protected by an automatic fire suppression system (usually a wet pipe sprinkler system). DOE has historically considered a facility with a maximum possible fire loss (MPFL) in excess of $\$ 1$ million as being significant from a property protection standpoint. 
In accordance with these requirements, the following fire protection systems and features are provided:

- Fire detection and alarm systems are provided in all buildings.

- Automatic fire sprinkler systems are used throughout the facilities, including the product receiving and shipping warehouse.

- The administration building and the product receiving and shipping warehouse (where the majority of the workers are located) are subdivided by fire-rated barriers to limit the maximum possible fire loss and to protect life by providing fire-rated escape routes for operating personnel.

It is assumed during building design that water for fire fighting would be obtained from the domestic system. Necessary equipment would include water pumps and area distribution loops.

\subsubsection{Overview of Disposal Facilities}

For purposes of this report, a disposal facility would be a single-purpose facility intended for permanent disposal of drums containing depleted uranium. It would be designed for receiving, inspecting, and repackaging (when necessary) drums of depleted $\mathrm{UF}_{4}$ and disposing of them in disposal units. A disposal facility for this purpose would have the following support facilities: an administration building, a receiving warehouse, a repackaging area, and a workshop. The repackaging area would share a building (product receiving and shipping warehouse) with the receiving warehouse.

The process flow within a disposal facility would be as follows. Drums of depleted uranium would be received at the facility by rail or road and be unloaded by davit crane at an unloading dock attached to the product receiving and shipping warehouse. Drums would be inspected for damage and external smearable contamination in the product receiving and shipping warehouse. Undamaged drums without smearable contamination would be transported to a temporary storage area by a bridge crane. Damaged drums and contaminated drums would be transported to a repackaging area, where the contents of damaged and contaminated drums would be transferred to new drums, reinspected, and then transferred back to the area where undamaged drums are placed in temporary storage.

Drums containing $\mathrm{UF}_{4}$ would be transported on pallets by truck from the temporary storage area in the product receiving and shipping warehouse to a disposal unit. For disposal in engineered trenches and vaults, mobile cranes on track vehicles would be used for emplacement. For disposal in mined cavities, forklifts would be used for emplacement. 
Operations at a disposal facility would require little energy and few materials. The major consumable item would be the diesel fuel used in the on-site movement of the drums. Minor amounts of wastes would be generated, the most notable being the air emissions from on-site diesel transport and from minimal space heating, and the waste resulting from damaged drums, which would be assumed to be low-level (radioactive) waste (LLW). Material and energy flows for a disposal facility would be dominated by the material and energy used in its construction.

The depleted uranium waste material flows, from depleted $\mathrm{UF}_{6}$ through drum storage as depleted $\mathrm{UF}_{4}$, are shown on Figures 1.1a and 1.1b. These figures reflect the original and new inventories, respectively.

Process flow diagrams for construction and operation of the wasteform facility (which includes the product receiving and shipping warehouse), assuming the new inventory, are provided in Figures 1.2a and 1.2b, and 1.3a and 1.3b, respectively.

\subsection{DEPLETED URANIUM WASTE FORM FOR DISPOSAL}

For this analysis, it is assumed that the disposal facility would be located on an arid site that may be either a DOE site, subject to site-specific WAC and DOE orders, or a commercial site, subject to a radioactive material license issued by an Agreement State and regulations promulgated by the NRC in 10 CFR Part 61, Licensing Requirements for Land Disposal of Radioactive Waste (NRC 2000). Although there may be other disposal facilities at the location, it is assumed that depleted $\mathrm{UF}_{4}$ would be disposed of in a separate disposal facility in a waste form that meets the requisite WAC or radioactive material license conditions. Representative DOE and commercial sites for this disposal facility would be the NTS and the Envirocare site in Tooele County, Utah, respectively. It is assumed that the facility for disposal of UF4 would be required to comply with waste acceptance criteria (e.g., the WAC for the existing disposal facility at NTS) that meet the requirements of DOE M 435.1-1, Radioactive Waste Management Manual, or radiological material license conditions (e.g., those for the Envirocare facility) that meet the requirements of $10 \mathrm{CFR}$ Part 61. More information about these requirements is provided in Section 9. A mined cavity would not be land disposal as defined in 10 CFR Part 61; nor does DOE M 435.1-1 address such an option. Hence, regulatory conditions for disposal of $\mathrm{UF}_{4}$ in a deep mined cavity are not well-defined.

\subsection{DISPOSAL IN AN ENGINEERED TRENCH}

Engineered trenches are well suited for disposing of low-activity waste in an arid climate. As discussed in the Engineering Analysis Report, the length of a trench is limited by such factors as site conditions and the volume of waste received per unit time. Trench widths may be dictated by the amount of radiation the workers might be exposed to, stability of the trench walls, the volume and/or size of the waste to be buried, types and weights of excavating and compacting 
machinery, and site conditions, such as topological relief. Factors influencing the depth include the physical aspects of the waste size, stability of the soil slopes, depth to bedrock and to waterbearing zones, permissible proximity of the top of the waste to the ground surface, and the type and amount of cover and liner required. The depth of the water table is the primary factor that limits the depth of a trench. The bottom of a trench should be sufficiently distant from the water table so as not to disturb it. Usually the floor of a trench slopes gently to collect infiltrated water.

Waste must be emplaced in a manner that maintains the structural integrity of the disposal containers and of the disposal facility. To minimize the effects of subsidence of the disposal facility, spaces between containers should be filled with earth, sand, gravel, or like material as each waste layer is placed. The most efficient means of emplacing the disposal containers is to put them on pallets and use forklifts to emplace the loaded pallets. Pallets might introduce some spaces, but are strong enough to hold the disposal containers without deforming. The Engineering Analysis Report assumes that the drums would be placed on wooden pallets and a forklift would be used to place the pallets in engineered trenches. To direct rain away from a trench, backfill should extend to a maximum of 1 meter above the local grade and be sloped. The total estimated area required for the engineered trench disposal facility is given in Tables 1.4a and $1.4 \mathrm{~b}$ for the original depleted uranium inventory and the new inventory, respectively. Tables 1.5a and 1.5b show the process flow for construction and operation of an engineered trench for the original inventory of depleted uranium and the new inventory, respectively. Figures $1.4 \mathrm{a}$ and $1.4 \mathrm{~b}$ and $1.5 \mathrm{a}$ and $1.5 \mathrm{~b}$ portray the information in Tables $1.5 \mathrm{a}$ and $1.5 \mathrm{~b}$ in graphical format for the new inventory.

\subsection{DISPOSAL IN A VAULT}

As stated in the Engineering Analysis Report, one option to be addressed is disposal in a concrete vault. In this report, it is assumed that the vault would be made of reinforced concrete and be built just below grade. Excavated material would be mounded above the vault and the original grade as a water/intruder resistant cap. Table 1.6 shows the number of vaults and the site area needed as a function of drum size and depleted uranium inventory. Table 1.7 shows the process flow for construction and operation of one vault. Figures $1.6 \mathrm{a}$ and $1.6 \mathrm{~b}$ and $1.7 \mathrm{a}$ and $1.7 \mathrm{~b}$ portray the information in Table 1.7 in graphical format for the new inventory. Section 2 provides the dimensions and a specific description of the vault.

\subsection{DISPOSAL IN A MINED CAVITY}

The design for a mined-cavity disposal facility follows the conceptual design found in the Engineering Analysis Report for the oxide waste forms. A mined-cavity disposal facility would consist of (1) surface facilities that provide space for waste receiving and inspection and shafts and ramps for access to and ventilation of the underground portion of the facility; (2) tunnels ("drifts") for the transport of waste for underground emplacement and emplacement itself and tunnels for the removal of excavated rock and for serving the area; (3) a waste ramp to permit 
transport of waste containers to the underground emplacement facilities; and (4) a ramp that would be used for excavating and constructing the underground facility and for removing excavated rock. The facility would also include shafts for the movement of workers and materials between the surface and underground areas, for utility access, and for ventilation of emplacement areas, underground shops and support areas, and decontamination areas.

Although components of a mined-cavity disposal facility for depleted uranium would be similar to those for the Yucca Mountain repository, emplacement in this facility can be denser than in Yucca Mountain because concerns about shielding of workers, heat generation, and criticality safety are not nearly as acute or are absent for the facility discussed here. As for mined-cavity disposal of depleted uranium in the oxide waste forms, emplacements would be spaced $32 \mathrm{~m}(105 \mathrm{ft})$ on centers, which is consistent with other tunneling in other mine media.

Material flows and energy balances for construction and operation of a mined-cavity disposal facility are shown in Tables $1.8 \mathrm{a}$ and $1.8 \mathrm{~b}$ for the original inventory and the new inventory, respectively. Figures $1.8 \mathrm{a}$ and $1.8 \mathrm{~b}$ and $1.9 \mathrm{a}$ and $1.9 \mathrm{~b}$ portray the information in Tables $1.8 \mathrm{a}$ and $1.8 \mathrm{~b}$ in graphical format for the new inventory.

During the construction phase, the primary output of the mined-cavity disposal facility would be material excavated to provide underground access, as well as the drifts in which the palletized waste drums would be stacked. The principal construction material used would be steel-reinforced concrete to line the drifts and to provide for ramps, roadways, and foundations. In addition, major services, such as potable water supply, air-conditioning, and ventilation must be provided. The construction phase would be the most energy-intensive phase because of energy consumption by excavating equipment. In the operating phase, energy consumption would be primarily by materials-handling equipment, such as fork-lifts, conveyors, and elevators. Tables $1.4 \mathrm{a}$ and $1.4 \mathrm{~b}$ show the total length of emplacement drifts and the site area needed for the original inventory and the new inventory, respectively. 
TABLE 1.1 Physical Properties of Uranium Tetrafluoride

\begin{tabular}{cccc}
\hline $\begin{array}{c}\text { Melting Point } \\
\left({ }^{\circ} \mathrm{C}\right)\end{array}$ & $\begin{array}{c}\text { Bulk Density } \\
\left(\mathrm{g} / \mathrm{cm}^{3}\right)\end{array}$ & $\begin{array}{c}\text { Solubility in Water, } \\
\text { Neutral } \mathrm{pH}\end{array}$ & $\begin{array}{c}\text { Inhalation } \\
\text { Solubility Class }\end{array}$ \\
\hline $960 \pm 5$ & $2.0-4.5$ & Very slightly soluble & W \\
\hline
\end{tabular}

a As established by the International Commission on Radiation Protection, Class "W" material is relatively insoluble; lung retention time is weeks.

Source: Martin Marietta Energy Systems (1990).

TABLE 1.2 Characteristics of Drum Disposal Containers

\begin{tabular}{|c|c|c|c|c|}
\hline $\begin{array}{l}\text { Drum Capacity } \\
\text { (gallons) }\end{array}$ & $\begin{array}{l}\text { Height } \\
(\mathrm{cm})\end{array}$ & $\begin{array}{c}\text { Outside } \\
\text { Diameter } \\
(\mathrm{cm})\end{array}$ & $\begin{array}{c}\text { Gauge/Wall } \\
\text { Thickness } \\
(\mathrm{cm})\end{array}$ & $\begin{array}{c}\text { Weight } \\
\text { (empty) } \\
(\mathrm{kg})\end{array}$ \\
\hline 55 & 8.3 & 57.15 & $40.6 / 0.135$ & 34.0 \\
\hline 30 & 4.0 & 46.4 & $30.5 / 0.241$ & 45.4 \\
\hline
\end{tabular}

TABLE 1.3 Content and Number of UF 4 Disposal Containers $\left(3.2 \mathrm{gm} / \mathrm{cm}^{3}\right)$

\begin{tabular}{ccccc}
\hline & & \multicolumn{2}{c}{ Number of Drums } \\
\cline { 3 - 5 } $\begin{array}{c}\text { Drum Capacity } \\
\text { (gallons) }\end{array}$ & $\begin{array}{c}\text { Weight Drum } \\
\text { Contents (te) }\end{array}$ & $\begin{array}{c}\text { Amount of Uranium } \\
\text { per Drum (te) }\end{array}$ & $\begin{array}{c}\text { Original } \\
\text { Inventory }\end{array}$ & $\begin{array}{c}\text { New } \\
\text { Inventory }\end{array}$ \\
\hline 30 & 0.364 & 0.276 & $1.373 \mathrm{E}+06$ & $1.729 \mathrm{E}+06$ \\
55 & 0.667 & 0.504 & $0.749 \mathrm{E}+06$ & $0.943 \mathrm{E}+06$ \\
\hline
\end{tabular}


TABLE 1.4a Area Required for Trench and Underground Mined-Cavity Disposal, Original Inventory

\begin{tabular}{cccc}
\hline & & \multicolumn{2}{c}{ Underground Mined Cavity } \\
\cline { 3 - 4 } $\begin{array}{c}\text { Drum } \\
\text { Capacity } \\
\text { (gallons) }\end{array}$ & $\begin{array}{c}\text { Trench Disposal } \\
\text { Site Area } \\
\text { (hectares) }\end{array}$ & $\begin{array}{c}\text { Underground Area } \\
\text { (hectares) }\end{array}$ & $\begin{array}{c}\text { Emplacement Drift } \\
\text { Length (meters) }\end{array}$ \\
\hline 30 & 20.6 & 247 & 28,700 \\
55 & 17.4 & 187 & 22,500 \\
\hline
\end{tabular}

TABLE 1.4b Area Required for Trench and Underground Mined-Cavity Disposal, New Inventory

\begin{tabular}{cccc}
\hline & & \multicolumn{2}{c}{ Underground Mined Cavity } \\
\cline { 3 - 4 } $\begin{array}{c}\text { Drum } \\
\text { Capacity } \\
\text { (gallons) }\end{array}$ & $\begin{array}{c}\text { Trench Disposal } \\
\text { Site Area } \\
\text { (hectares) }\end{array}$ & $\begin{array}{c}\text { Underground Area } \\
\text { (hectares) }\end{array}$ & $\begin{array}{c}\text { Emplacement Drift } \\
\text { Length (meters) }\end{array}$ \\
\hline \multirow{2}{*}{30} & 25.5 & 310 & 38,428 \\
55 & 21.6 & 234 & 28,743 \\
\hline
\end{tabular}

TABLE 1.5a Annual Utility and Materials Requirements for Construction and Operation of the Engineered Trench Disposal Facility, Original Inventory

\begin{tabular}{|c|c|c|c|c|}
\hline Container & Group & Type & Construction & Operations \\
\hline \multirow{7}{*}{$\begin{array}{l}\text { 30-gallon } \\
\text { drums }\end{array}$} & \multirow[t]{3}{*}{ Utilities } & Electricity, kW-h & 221 & 1,030 \\
\hline & & Water, ML & 0.28 & 0.083 \\
\hline & & Diesel fuel, L & $5.69 \mathrm{E}+04$ & 148,300 \\
\hline & \multirow[t]{4}{*}{ Material } & Sand, $\mathrm{m}^{3}$ & 2,920 & \\
\hline & & Gravel, te & 122 & \\
\hline & & Clay, $\mathrm{m}^{3}$ & 424 & \\
\hline & & Excavated material, $\mathrm{m}^{3}$ & $6.45 \mathrm{E}+04$ & \\
\hline \multirow{7}{*}{$\begin{array}{l}\text { 55-gallon } \\
\text { drums }\end{array}$} & \multirow[t]{3}{*}{ Utilities } & Electricity, MW-h & 190 & 762 \\
\hline & & Water, ML & 0.27 & 0.052 \\
\hline & & Diesel fuel, L & $4.83 \mathrm{E}+04$ & 82,100 \\
\hline & \multirow[t]{4}{*}{ Material } & Sand, $\mathrm{m}^{3}$ & 2,430 & \\
\hline & & Gravel, te & 102 & \\
\hline & & Clay, $\mathrm{m}^{3}$ & 385 & \\
\hline & & Excavated material, $\mathrm{m}^{3}$ & $5.48 \mathrm{E}+04$ & \\
\hline
\end{tabular}


TABLE 1.5b Annual Utility and Materials Requirements for Construction and Operation of the Engineered Trench Disposal Facility, New Inventory

\begin{tabular}{|c|c|c|c|c|}
\hline Container & Group & Type & Construction & Operations \\
\hline \multirow[t]{2}{*}{$\begin{array}{l}\text { 30-gallon } \\
\text { drums }\end{array}$} & Utilities & $\begin{array}{l}\text { Electricity, kW-h } \\
\text { Water, ML } \\
\text { Diesel fuel, L }\end{array}$ & $\begin{array}{c}221 \\
0.29 \\
5.69 \mathrm{E}+04\end{array}$ & $\begin{array}{c}1,034 \\
0.084 \\
149,400\end{array}$ \\
\hline & Material & $\begin{array}{l}\text { Sand, } \mathrm{m}^{3} \\
\text { Gravel, te } \\
\text { Clay, } \mathrm{m}^{3} \\
\text { Excavated material, } \mathrm{m}^{3}\end{array}$ & $\begin{array}{c}2,920 \\
122 \\
424 \\
6.45 \mathrm{E}+04\end{array}$ & \\
\hline \multirow[t]{2}{*}{$\begin{array}{l}\text { 55-gallon } \\
\text { drums }\end{array}$} & Utilities & $\begin{array}{l}\text { Electricity, MW-h } \\
\text { Water, ML } \\
\text { Diesel fuel, L }\end{array}$ & $\begin{array}{c}190 \\
0.28 \\
4.83 \mathrm{E}+04\end{array}$ & $\begin{array}{c}765 \\
0.052 \\
82,600\end{array}$ \\
\hline & Material & $\begin{array}{l}\text { Sand, } \mathrm{m}^{3} \\
\text { Gravel, te } \\
\text { Clay, } \mathrm{m}^{3} \\
\text { Excavated material, } \mathrm{m}^{3}\end{array}$ & $\begin{array}{c}2,430 \\
102 \\
385 \\
5.48 \mathrm{E}+04\end{array}$ & \\
\hline
\end{tabular}

TABLE 1.6 Number of Disposal Vaults

\begin{tabular}{ccccc}
\hline $\begin{array}{c}\text { Drum Capacity } \\
\text { (gallons) }\end{array}$ & Inventory & $\begin{array}{c}\text { Number of Vaults } \\
\text { Annually }\end{array}$ & $\begin{array}{c}\text { Total Number } \\
\text { of Vaults }\end{array}$ & $\begin{array}{c}\text { Site Land Area } \\
\text { (hectares) }\end{array}$ \\
\hline & & & & \\
30 & Original & 3.8 & 76 & 25.4 \\
55 & Original & 4.2 & 84 & 31.6 \\
30 & New & 3.8 & 95 & 31.6 \\
55 & New & 4.2 & 105 & 37.9 \\
\hline
\end{tabular}


TABLE 1.7 Utility and Materials Requirements for Construction and Operation of the Vault Disposal Facility, One Vault

\begin{tabular}{clcc}
\hline \multirow{2}{*}{ Group } & \multicolumn{1}{c}{ Type } & Construction & Operations \\
\hline \multirow{3}{*}{ Utilities } & & & \\
& Electricity, MW-h & 12,500 & 328 \\
& Water, ML & 0.78 & 0.02 \\
& Diesel fuel, L & 17,800 & 51,100 \\
\hline \multirow{3}{*}{ Materials } & & 1,750 & \\
& Redi-mix, $\mathrm{m}^{3}$ & 58.5 & \\
& Steel, te & 910 & \\
& Gravel, te & 2,220 & \\
& Liner, $\mathrm{m}^{3}$ & 7,520 & \\
& Excavated material, $\mathrm{m}^{3}$ &
\end{tabular}

TABLE 1.8a Utility and Materials Requirements for Construction and Operation of the Mined-Cavity Disposal Facility, Original Inventory (total)

\begin{tabular}{|c|c|c|c|c|}
\hline Container & Group & Type & Construction & Operations \\
\hline \multirow[t]{2}{*}{$\begin{array}{l}\text { 30-gallon } \\
\text { drums }\end{array}$} & Utilities & $\begin{array}{l}\text { Electricity, GW-h } \\
\text { Water, ML } \\
\text { Diesel fuel, L }\end{array}$ & $\begin{array}{c}5,760 \\
16.7 \\
716,000\end{array}$ & $\begin{array}{c}166 \\
61.8 \\
186,000\end{array}$ \\
\hline & Materials & $\begin{array}{l}\text { Redi-Mix, } \mathrm{m}^{3} \\
\text { Steel, te }\end{array}$ & $\begin{array}{c}99,000 \\
3,890\end{array}$ & \\
\hline \multirow[t]{2}{*}{$\begin{array}{l}\text { 55-gallon } \\
\text { drums }\end{array}$} & Utilities & $\begin{array}{l}\text { Electricity, GW-h } \\
\text { Water, ML } \\
\text { Diesel fuel, L }\end{array}$ & $\begin{array}{c}4,810 \\
14.0 \\
990,000\end{array}$ & $\begin{array}{c}123 \\
46.5 \\
125,000\end{array}$ \\
\hline & Materials & $\begin{array}{l}\text { Redi-mix, } \mathrm{m}^{3} \\
\text { Steel, te }\end{array}$ & $\begin{array}{c}82,000 \\
3,230\end{array}$ & \\
\hline
\end{tabular}


TABLE 1.8b Utility and Materials Requirements for Construction and Operation of the Mined-Cavity Disposal Facility, New Inventory (total)

\begin{tabular}{lclcc}
\hline Container & Group & \multicolumn{1}{c}{ Type } & Construction & Operations \\
\hline \multirow{2}{*}{$\begin{array}{l}\text { 30-gallon } \\
\text { drums }\end{array}$} & \multirow{2}{*}{ Utilities } & Electricity, GW-h & 6,670 & 209 \\
& & Water, ML & 19.4 & 77.5 \\
& & Diesel fuel, L & 846,000 & 234,000 \\
& \multirow{2}{*}{ Materials } & Redi-mix, m ${ }^{3}$ & 116,000 & \\
& & Steel, te & 4,540 & \\
55-gallon & \multirow{2}{*}{ Utilities } & Electricity, GW-h & 5,540 & 154 \\
drums & & Water, ML & 16.1 & 58.3 \\
& & Diesel fuel, L & 684,000 & 157,000 \\
& & & \\
& \multirow{2}{*}{ Materials } & Redi-mix, m ${ }^{3}$ & 95,000 & \\
& & Steel, te & 3,740 & \\
\hline
\end{tabular}




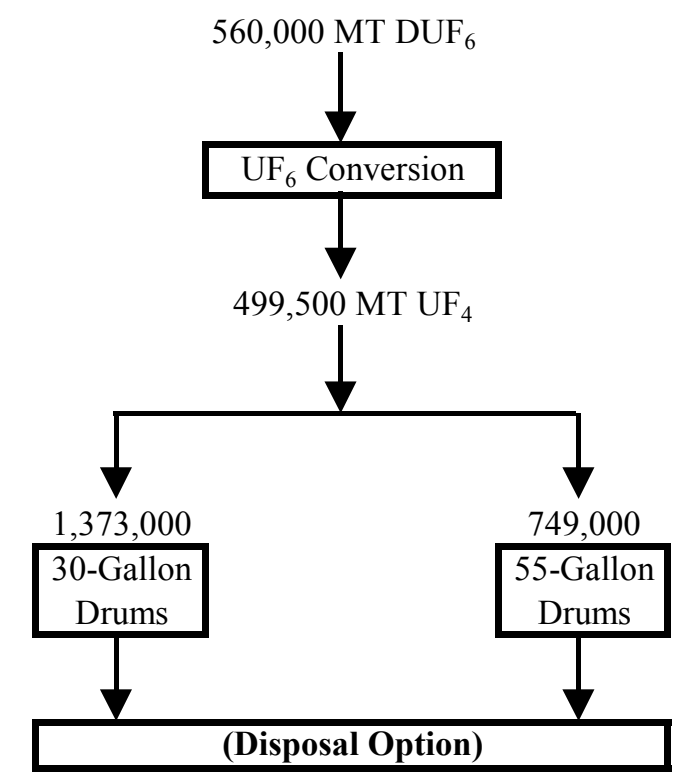

FIGURE 1.1a Material Flow Diagram, Old Inventory

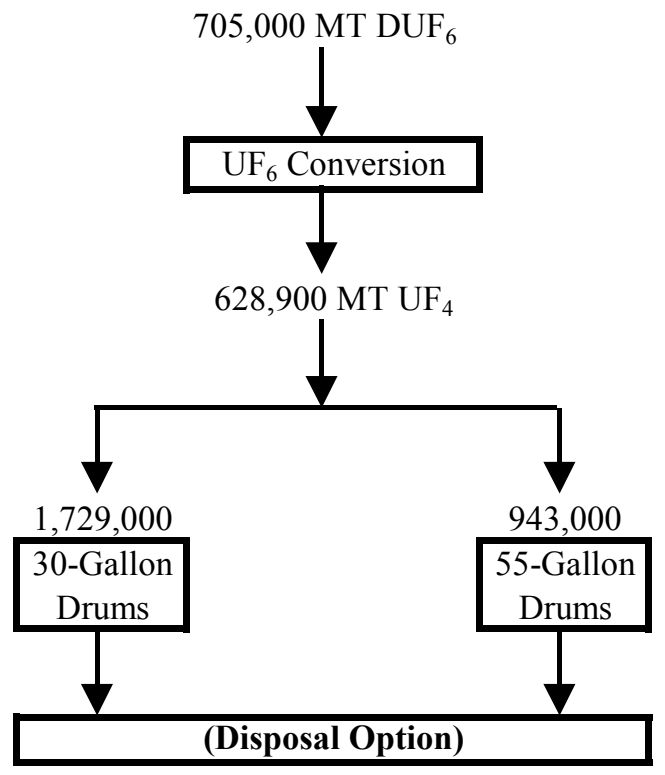

FIGURE 1.1b Material Flow Diagram, New Inventory 


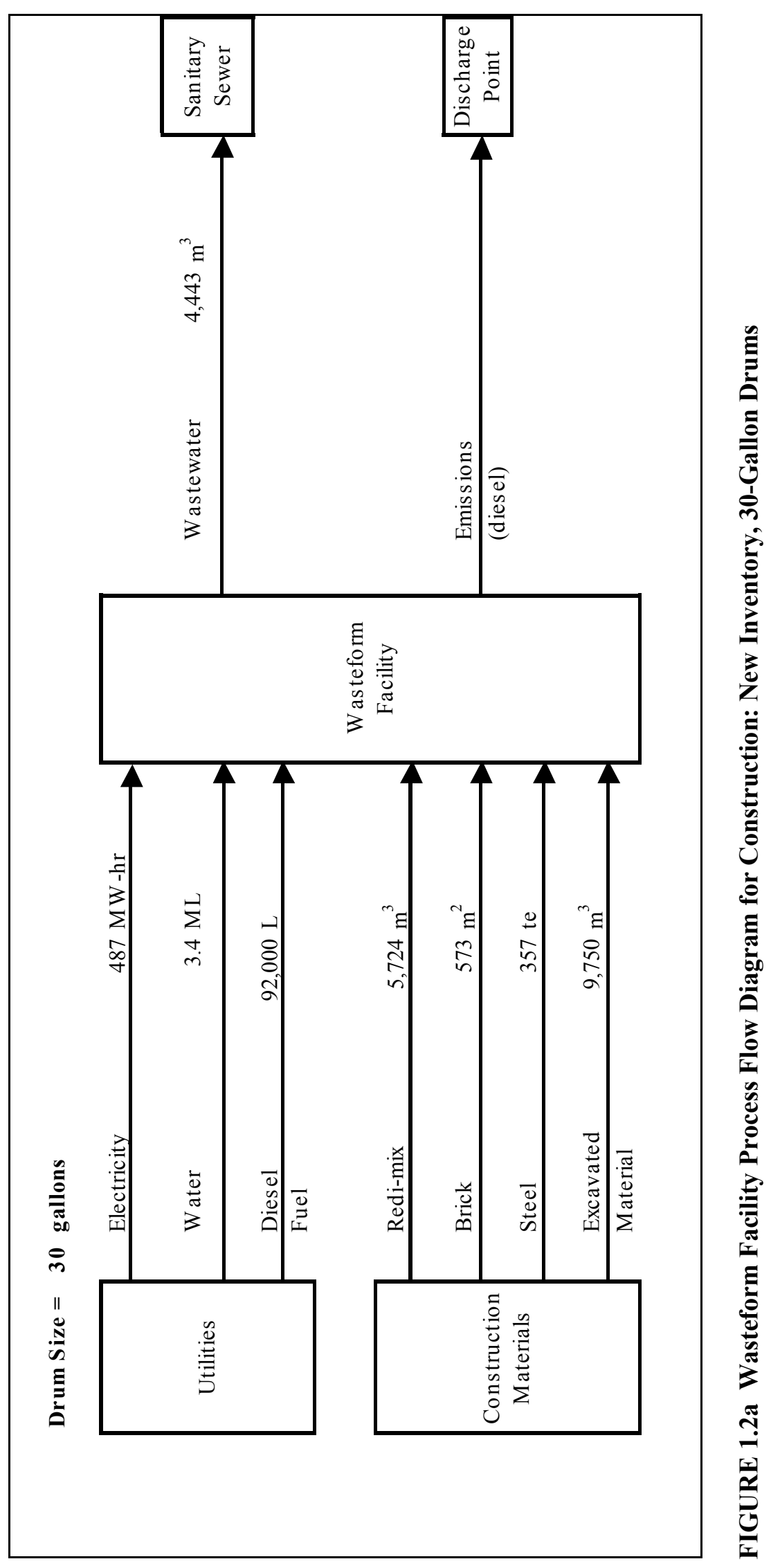




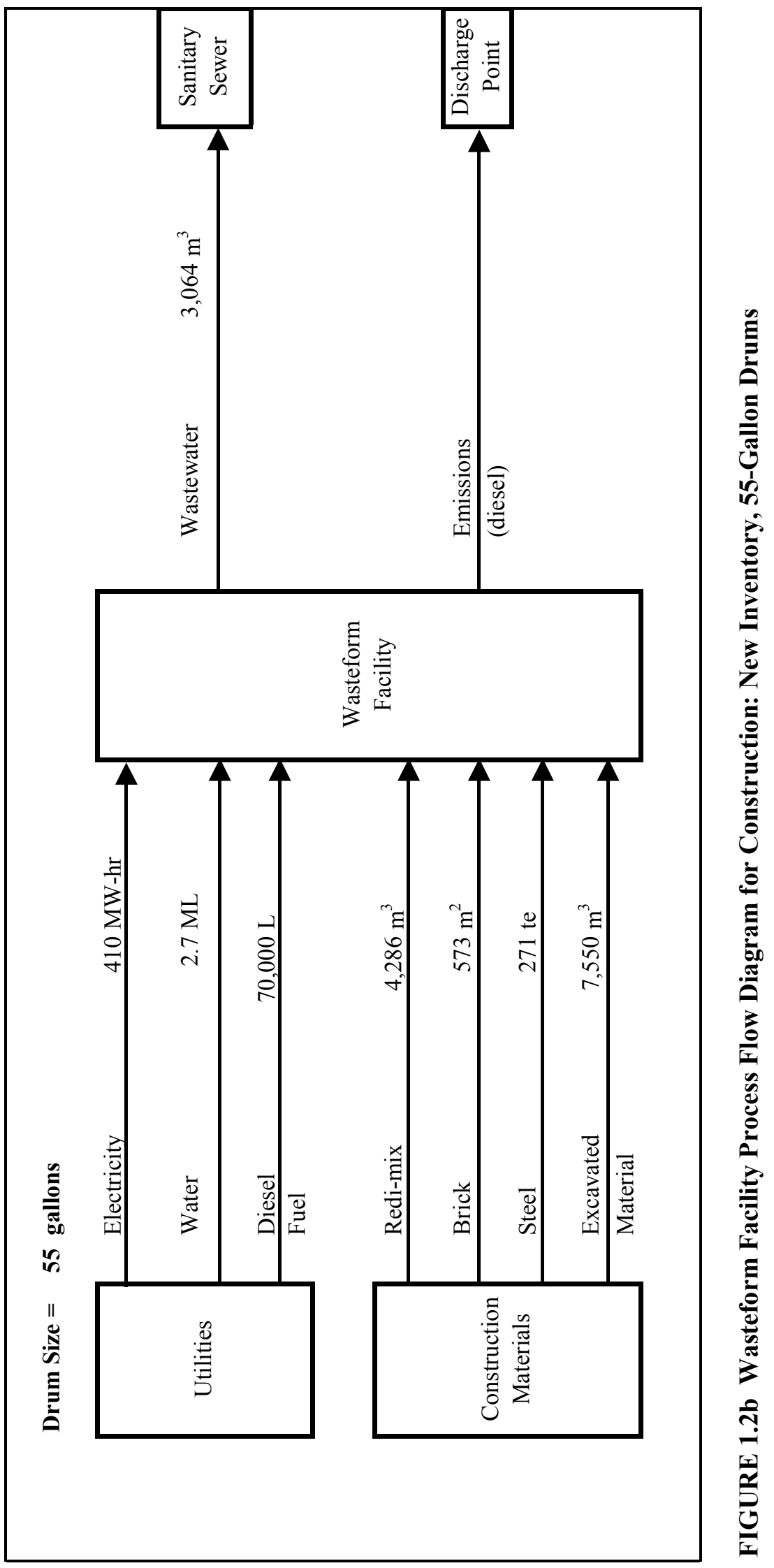




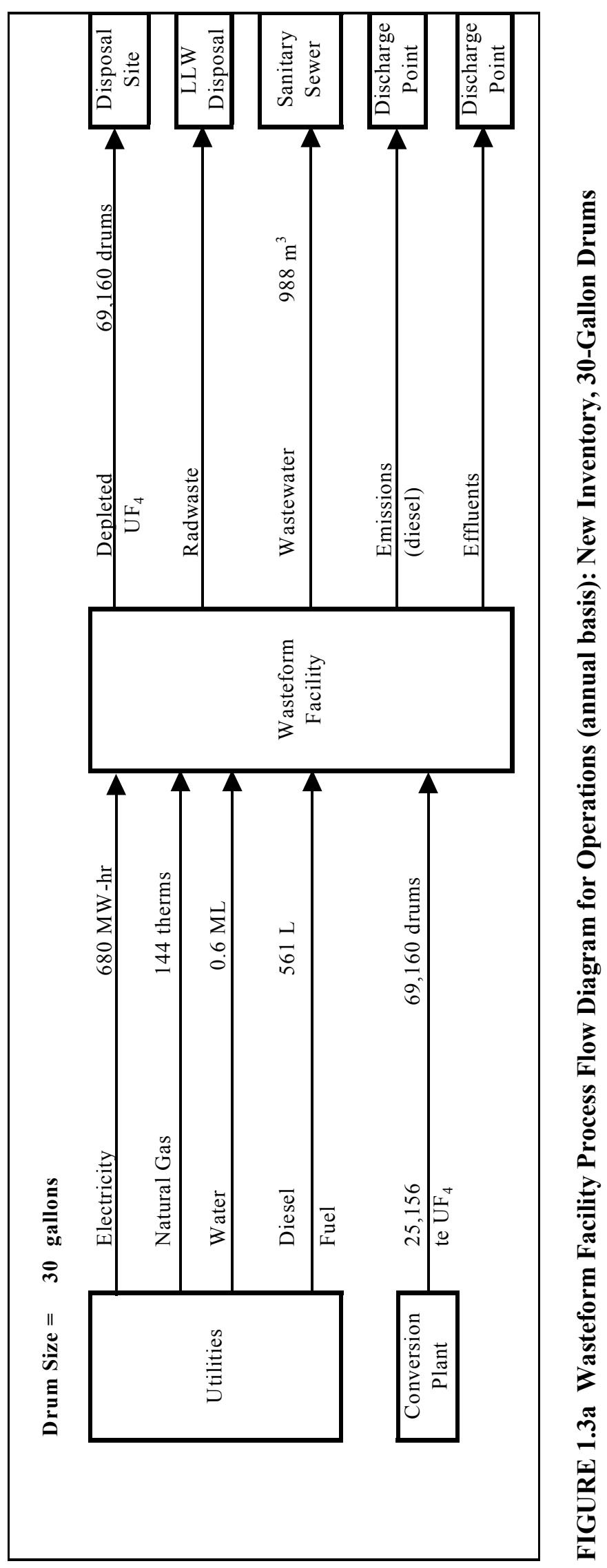




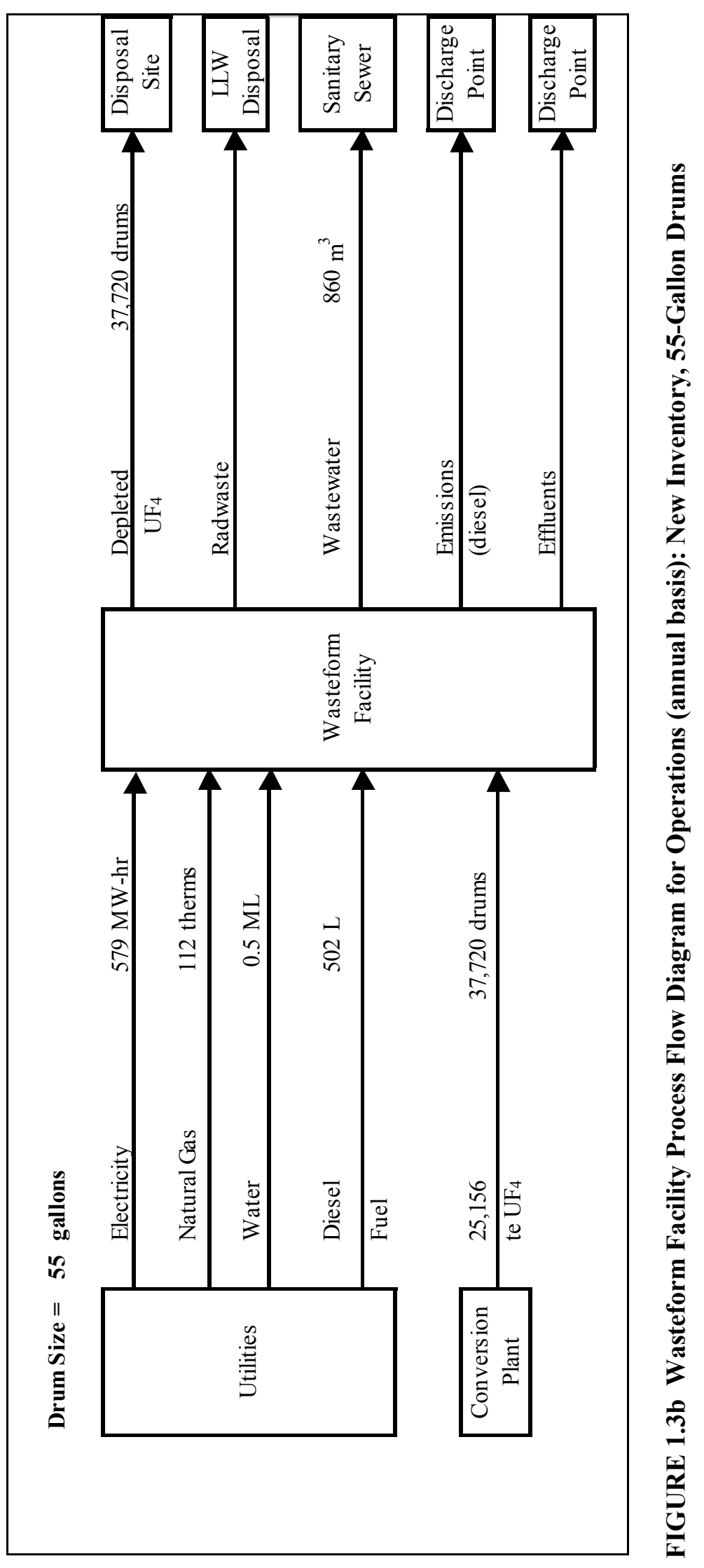




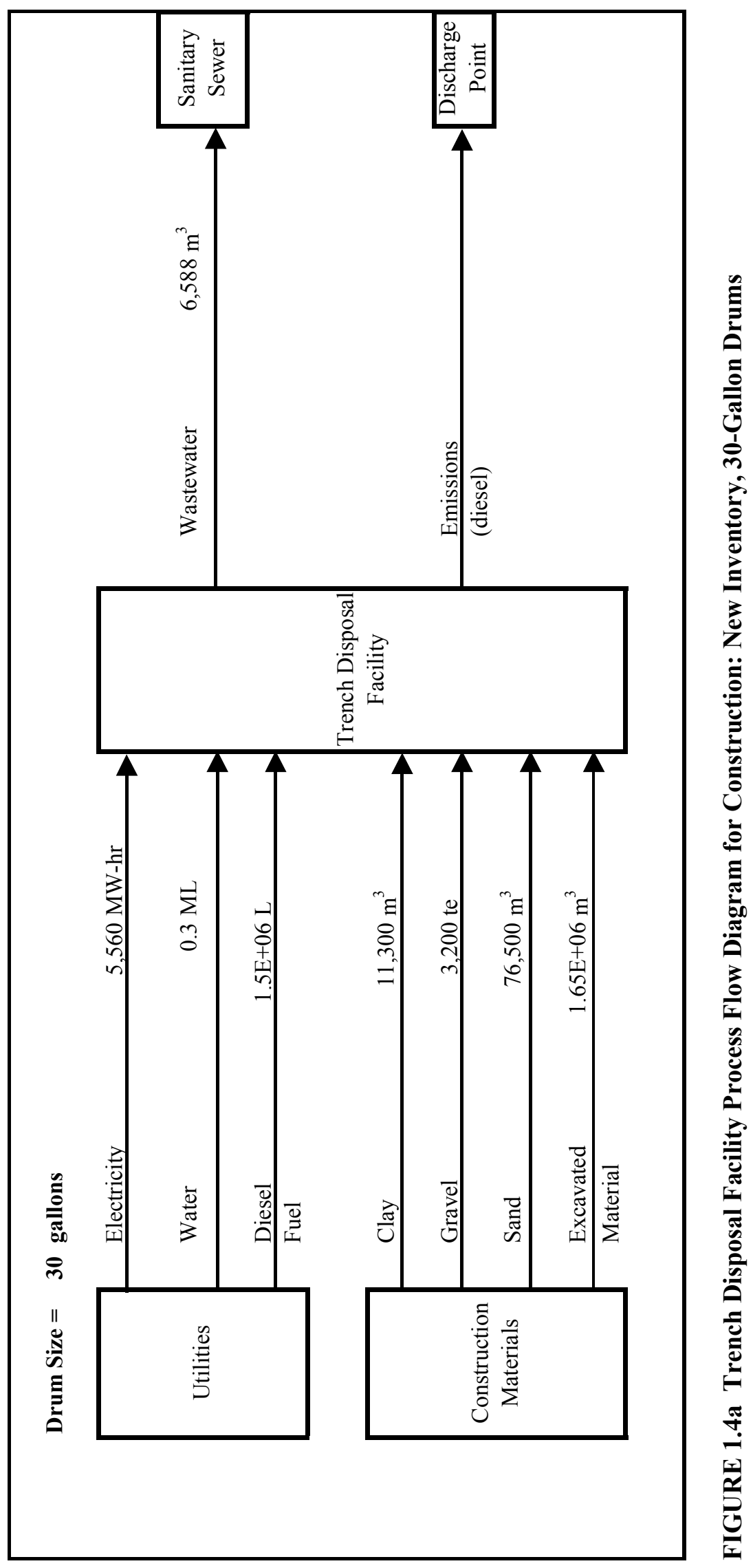


1-22

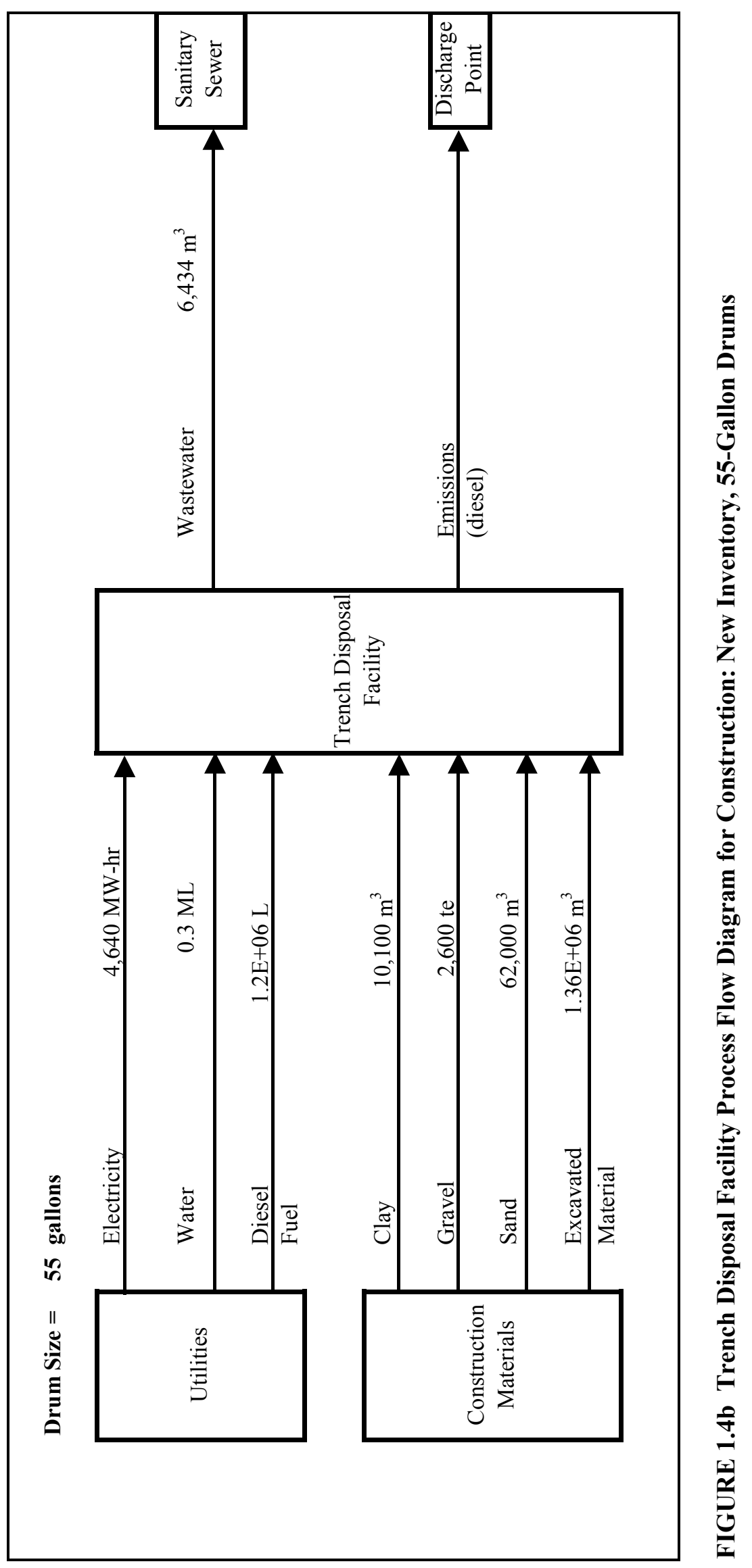


1-23

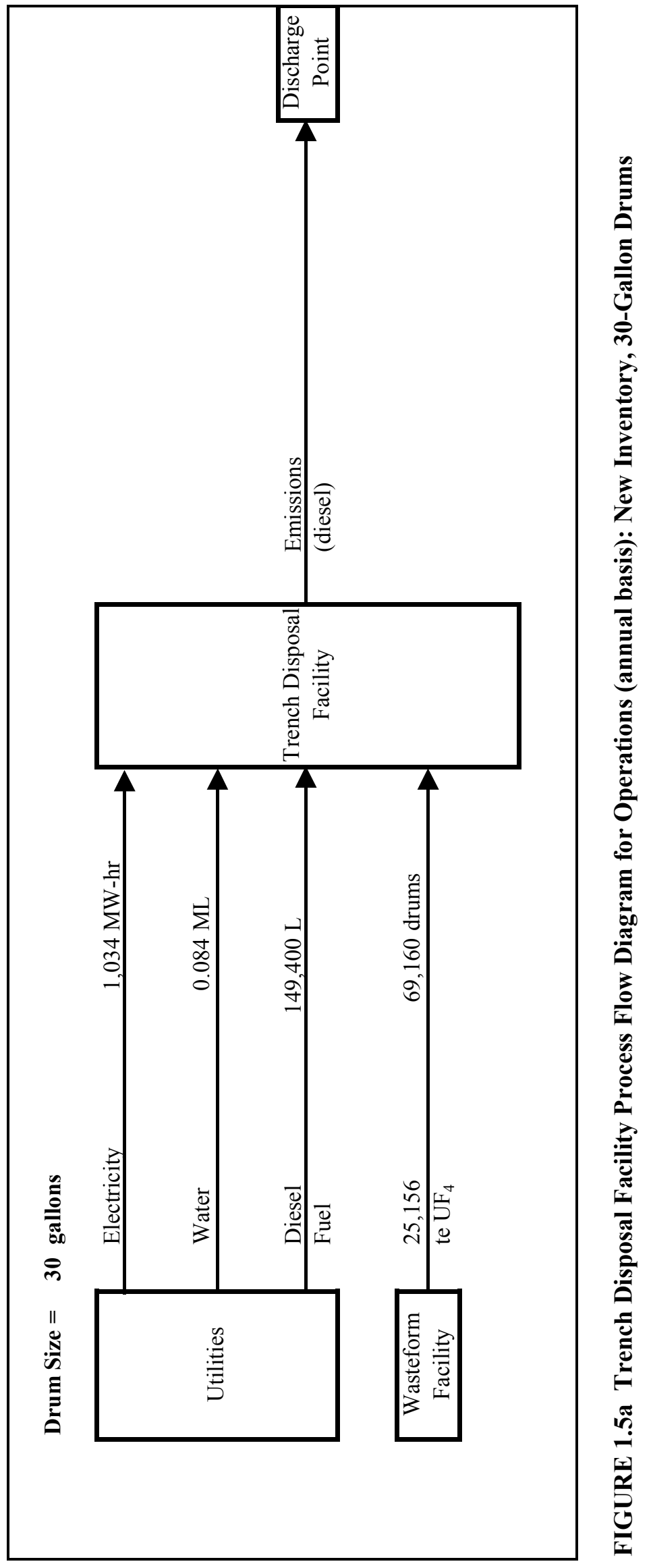




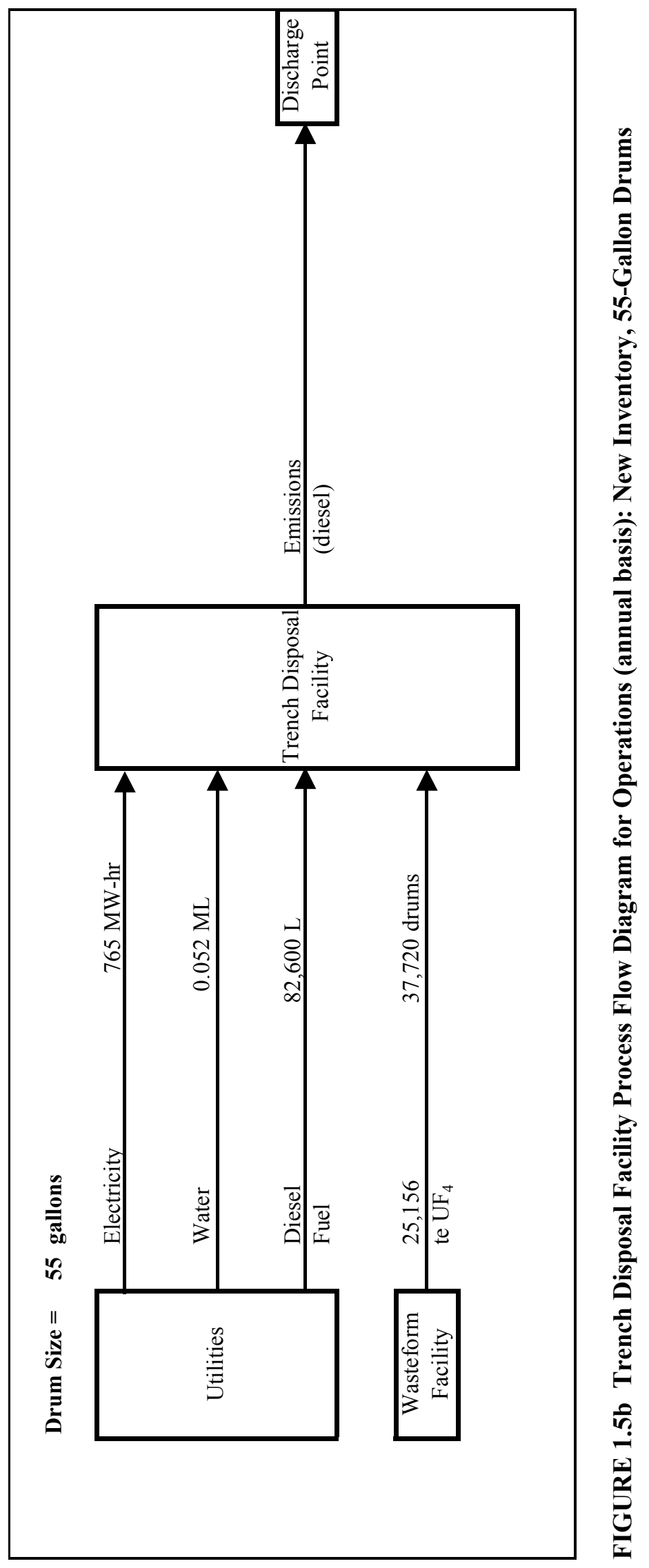




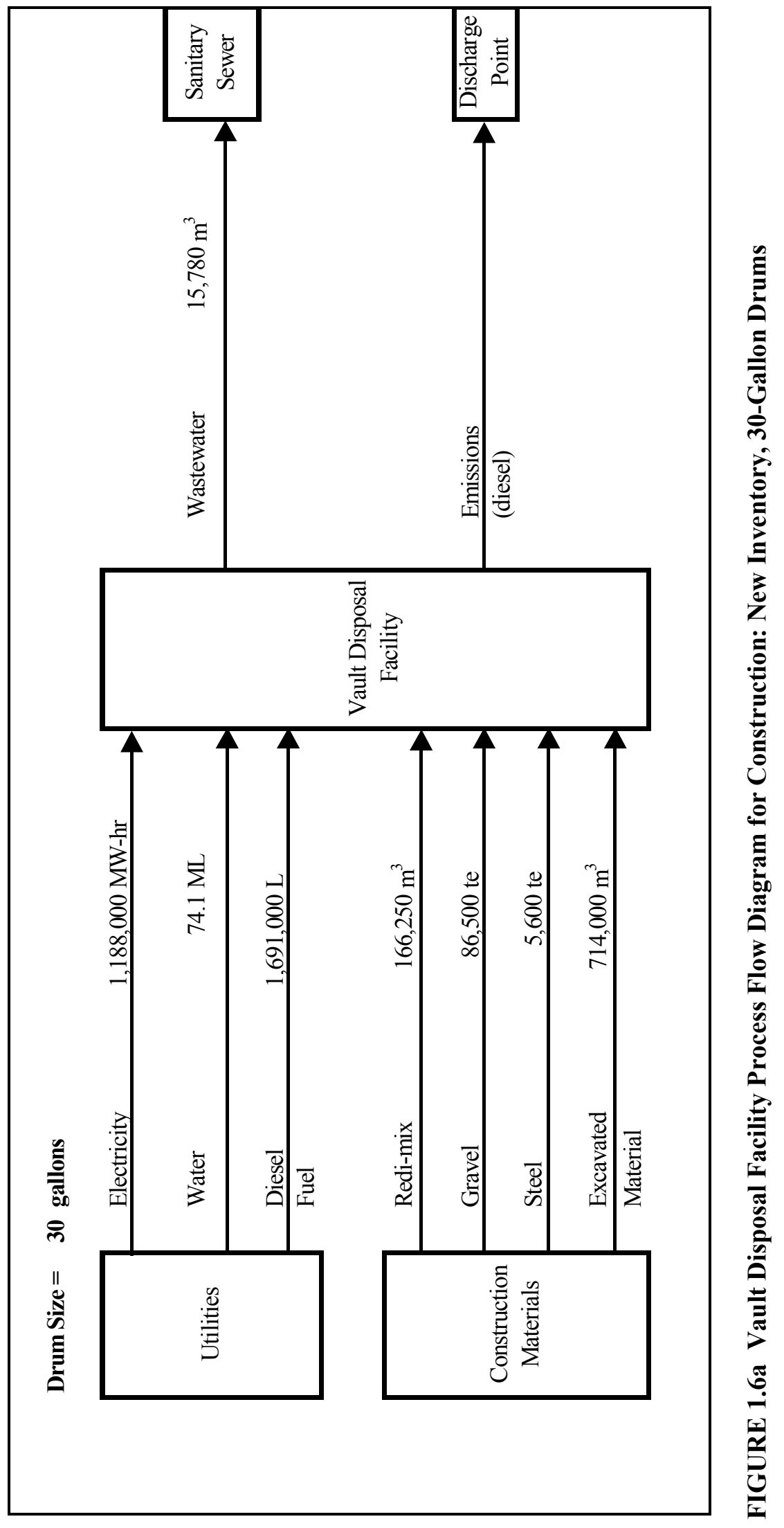




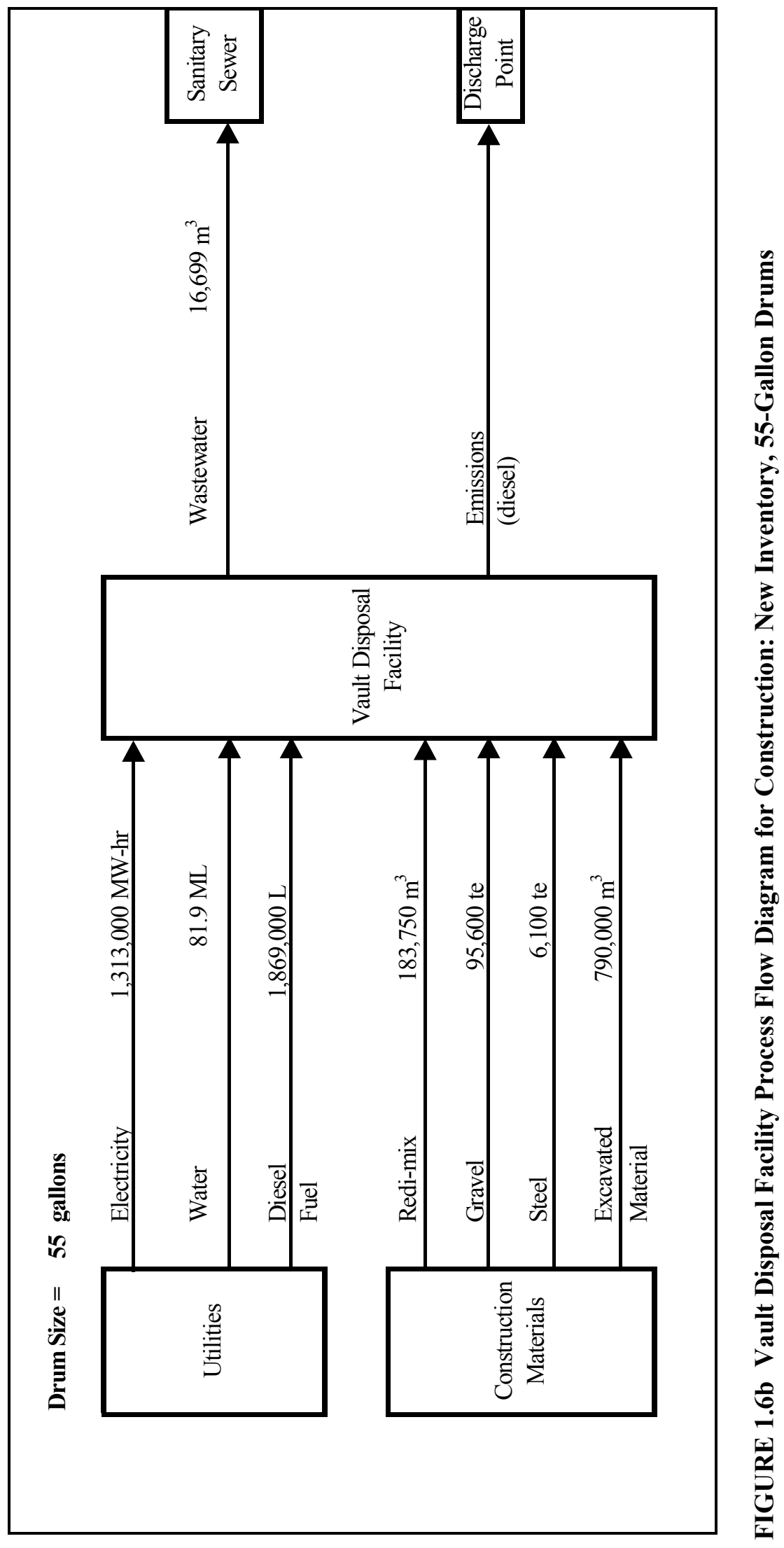




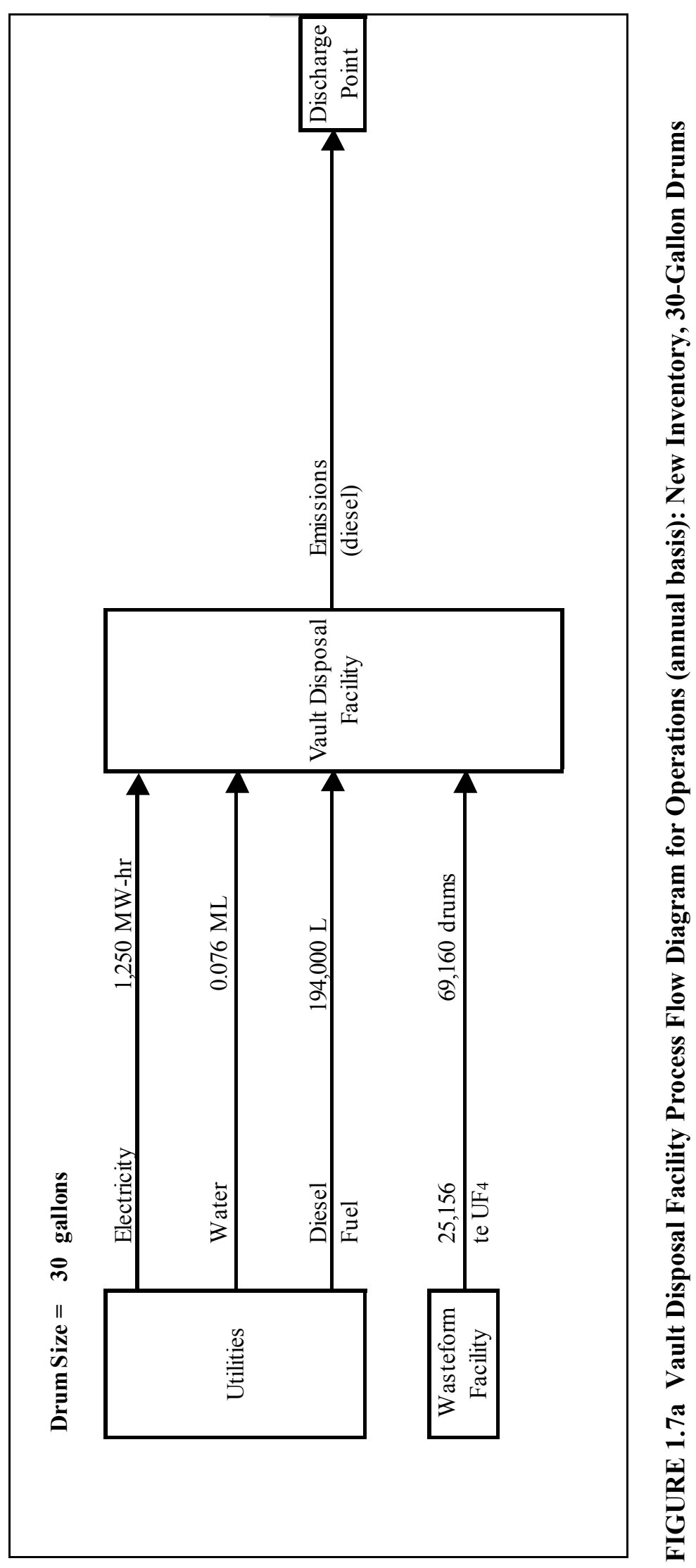




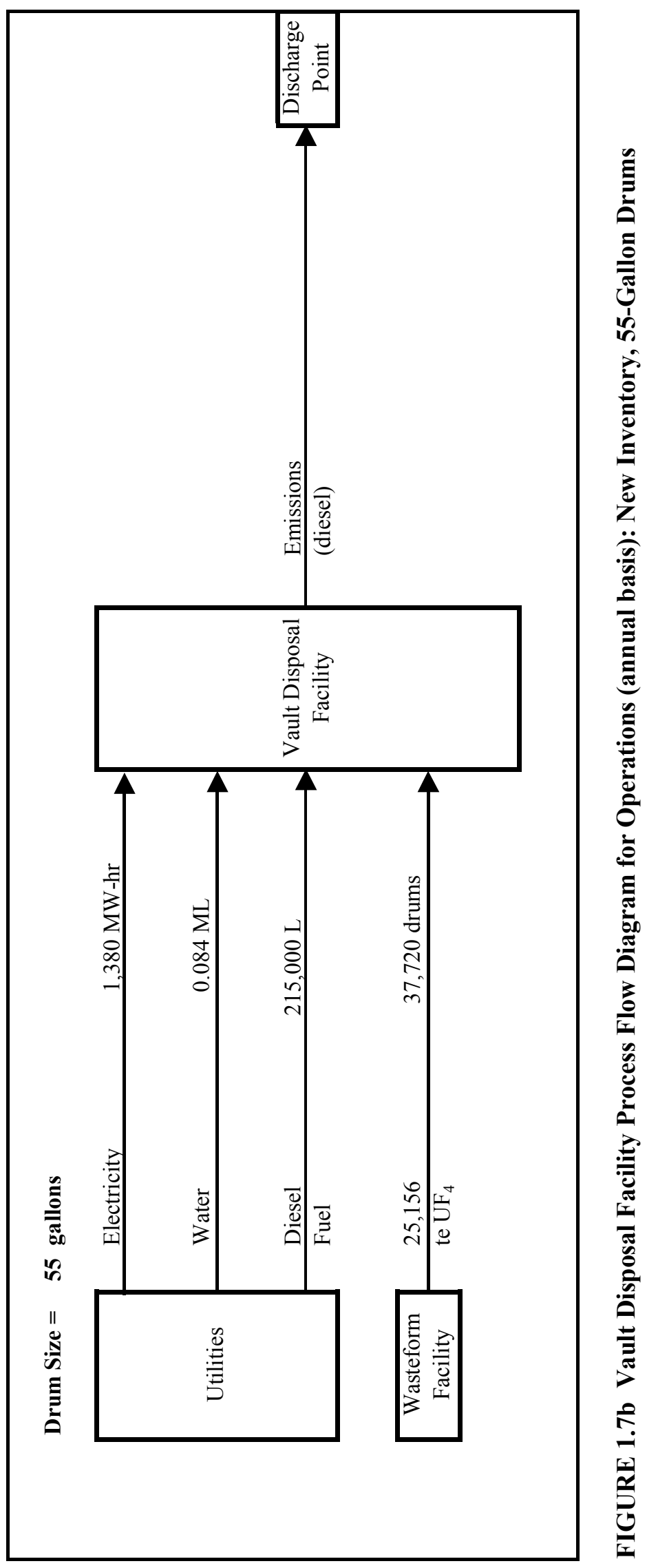




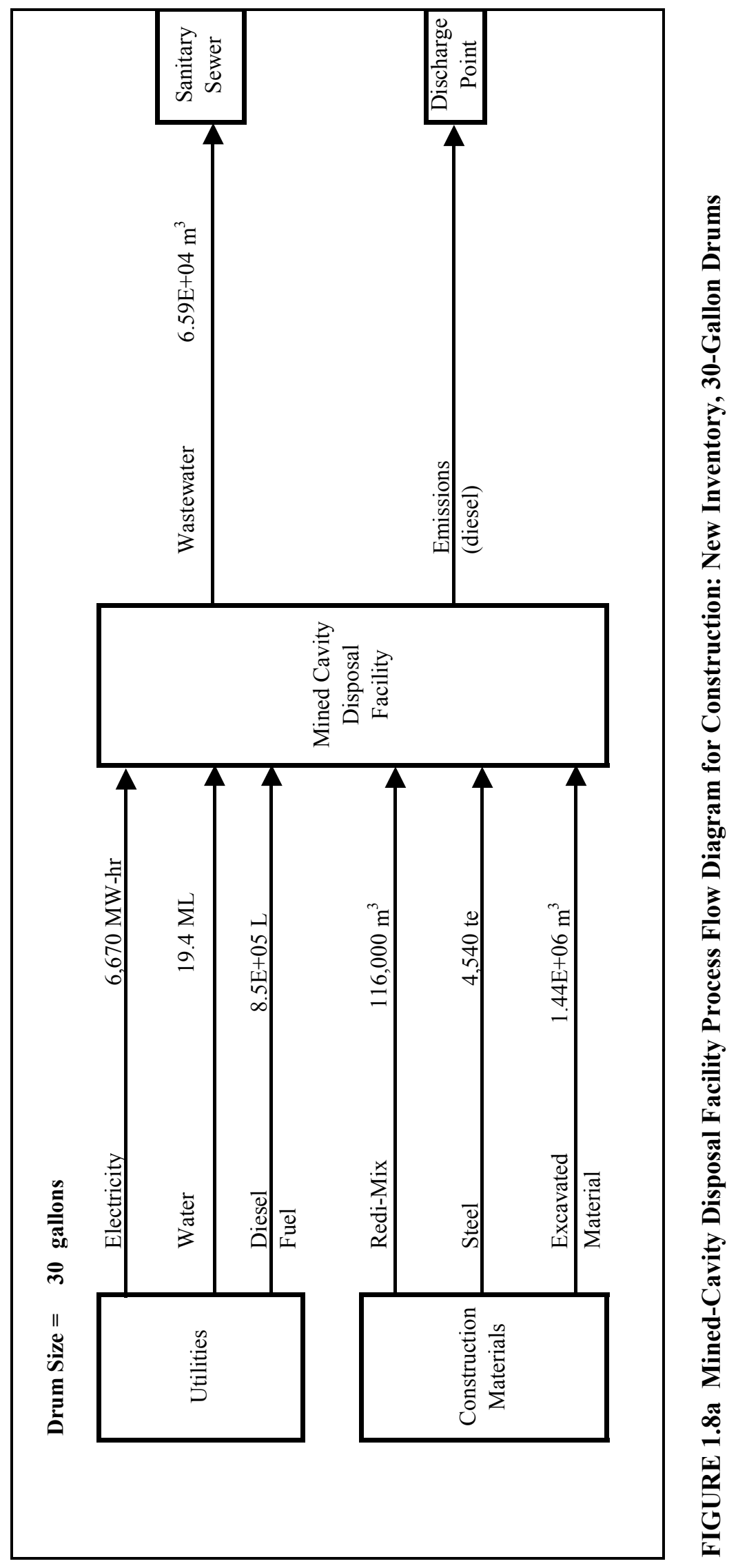




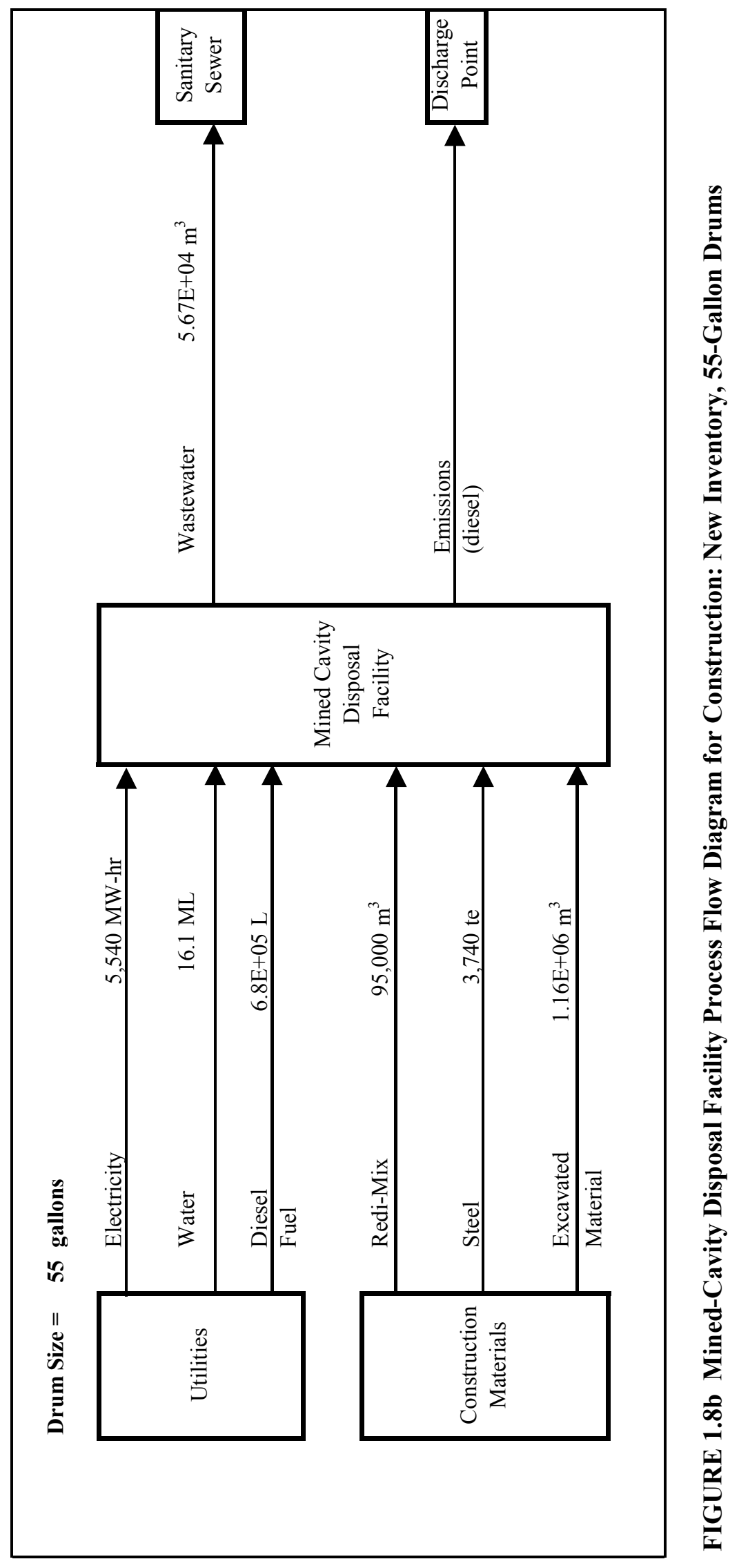



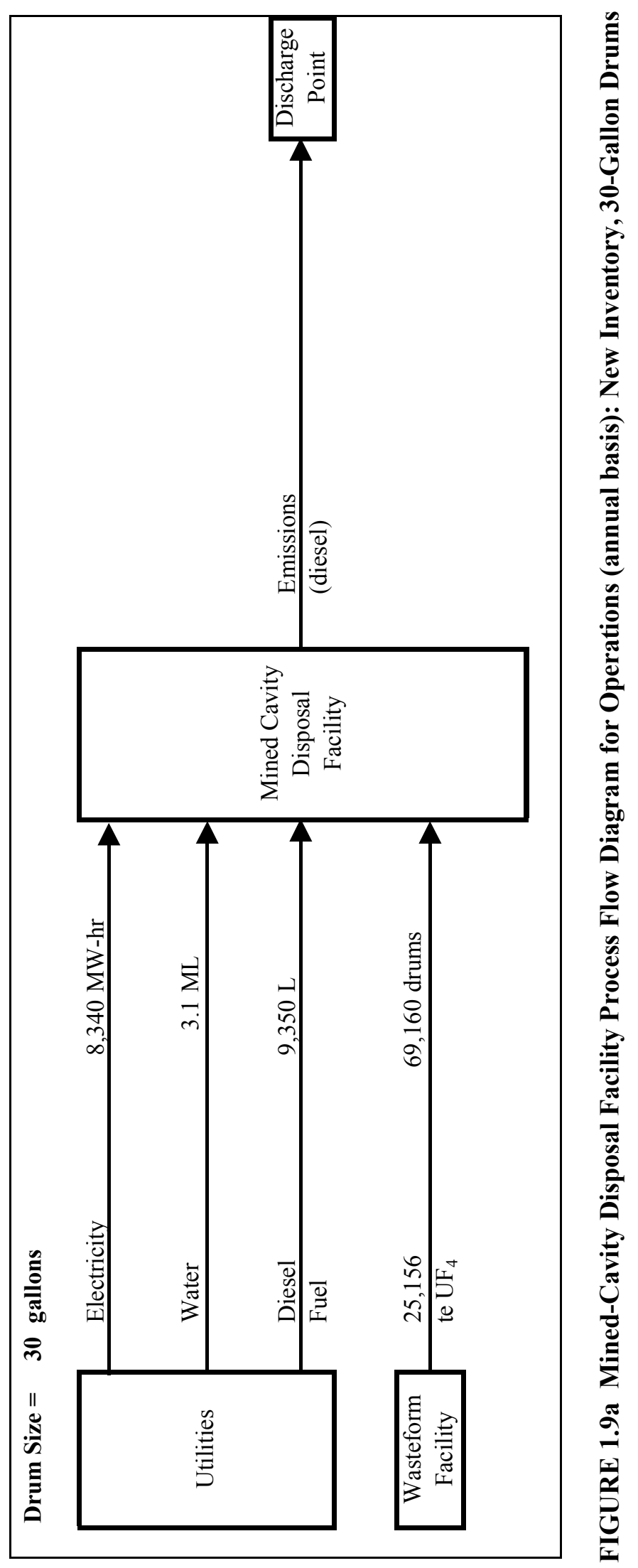


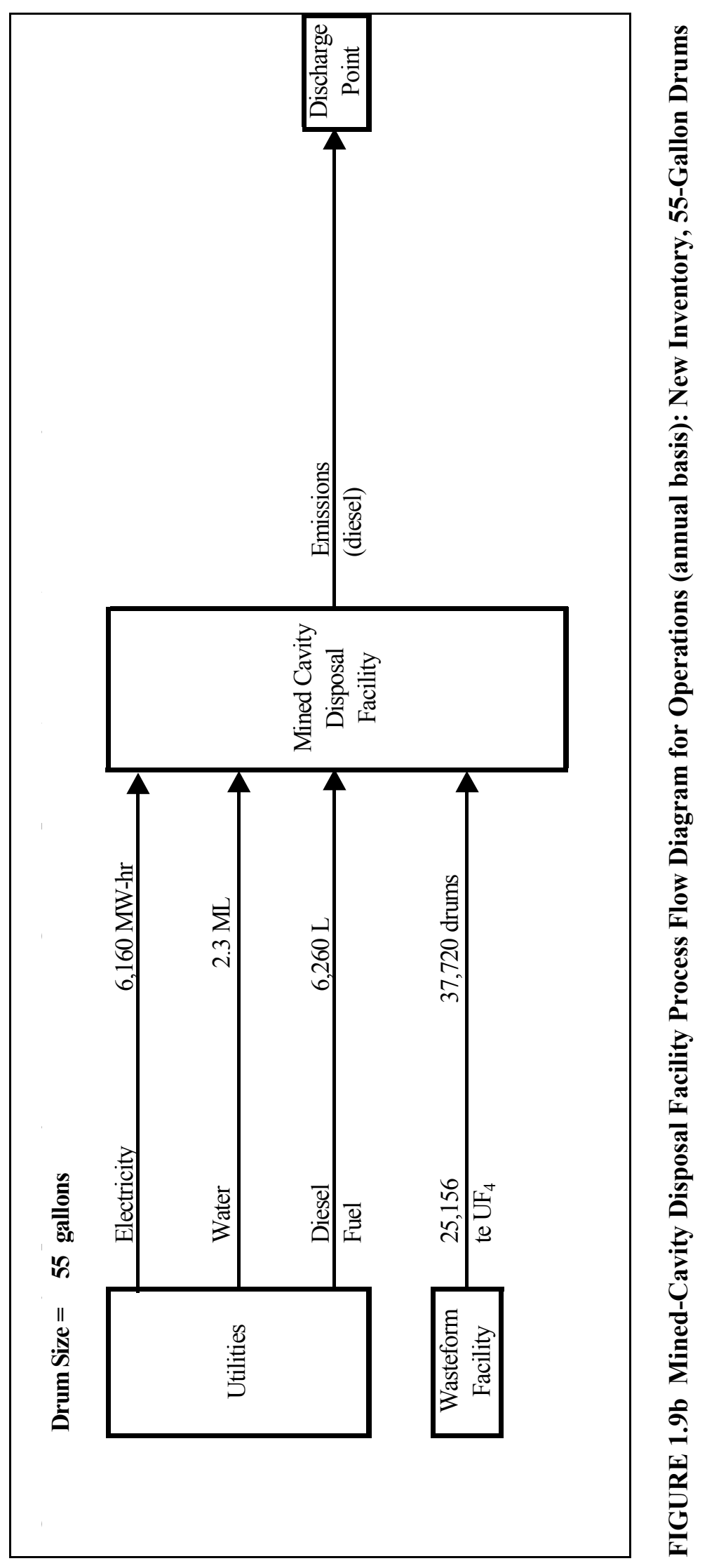




\section{DESCRIPTION OF THE FACILITY}

A disposal facility for depleted $\mathrm{UF}_{4}$ would require two major types of buildings in addition to the disposal area:

- A product receiving and shipping warehouse in which containers shipped to the disposal facility would be temporarily stored and then inspected and transported to a disposal unit. If the inspection showed that a drum was defective, its contents would be repackaged (i.e., transferred to another drum) before being transported to a disposal unit from the shipping part of the building; and

- An administration building incorporating all technical and administrative support functions needed to manage the operation of the storage facility. These functions would include security, facility access control, health physics and radiation badges, sanitary facilities, work control and personnel support, internal and external (public relations) communications, spill or emergency response provisions, analytical laboratory, environmental regulatory reporting, and records management for materials control and accountability (MC\&A).

\subsection{GENERAL DESIGN AND SAFETY CRITERIA}

The following criteria would used in the engineering design of the disposal facility:

- The disposal facility must provide for the receipt of materials over a 20-year period for the original inventory, or over a 25 -year period for the new inventory, and for permanent disposal thereafter. Means of ingress for depleted uranium for transportation by rail or truck should be provided.

- The disposal system must provide systems or methods for (1) inspection of the integrity of the drums before emplacement, (2) removal and management of any failed drum, (3) and inventory of material for MC\&A reporting.

- The facility must be designed, constructed, and operated to comply with the requirements of DOE O 420.1, Facility Safety, in general, and specifically in accordance with the guidance contained in DOE G 420.1-2, Guide for the Mitigation of Natural Phenomena Hazards for DOE Nuclear Facilities and Non-Nuclear Facilities. The general impact of this order and guide is that structures, systems, and components (SSCs) shall be designed to withstand the effects of natural phenomena hazards (NPH) to prevent loss of structural integrity that could endanger life safety. The guide provides for a graded approach to NPH protection using performance categories. 
Design criteria are contained in DOE-STD-1020-94, Natural Phenomena Hazards Design and Evaluation Criteria for Department of Energy Facilities (DOE 1994). The NPH standards in DOE-STD-1024-94 have five performance categories for selecting SSCs. The design and evaluation criterion in Performance Categories 0,1 , and 2 are similar to those in model building codes. For SSCs assigned to Performance Category 0, consideration of NPHs may not be needed. For SSCs assigned to Performance Category 1, provisions in model building codes that protect against NPHs are adequate. SSCs assigned to Performance Category 2, which involves criteria slightly more demanding than the design criteria for hospitals or fire or police stations should maintain functionality even when a natural phenomenon event (e.g., earthquake) occurs.

Performance Categories 3 and 4 are appropriate when there is a potential significant threat to the public safety and the environment should there be a SSC failure. SSCs assigned to these categories are designed to control and confine hazardous material so that damage is limited to within confinement barriers. A qualitative assessment of the hazard ranking and performance category for the proposed storage facility has been performed. Table 2.1 summarizes the results of this assessment. ${ }^{1}$

The administration building would be an office building that would not contain any uranium; however, it must continue to function after a seismic event or an accident. Therefore, it is given the lowest hazard and performance category ranking (2) appropriate for continuing operations after a natural phenomenon event.

No energetic processes would be performed in the product receiving and shipping warehouse, only movement of drums and pallets and repackaging. However, there would be a substantial inventory of uranium in the warehouse. Performance Category 2 SSCs and a low hazard ranking appear to be appropriate for this building, as well as for the disposal units.

The NRC requires in 10 CFR 61.12 that an application for a license to dispose of LLW contain specific technical information to address natural phenomenon events. An application should define design basis natural phenomena and their relationship to the principal design criteria. The application should also describe the codes and standards that the applicant has applied to the design and that will apply to construction of the disposal facility. The design criteria required by the NRC or an Agreement State would be expected to be similar to the design criteria required by DOE.

\subsection{ENGINEERED TRENCH DISPOSAL FACILITY}

As discussed in Section 2.5, the product receiving and shipping warehouse and administration building are collectively referred to as the wasteform facility to be consistent with

\footnotetext{
${ }^{1}$ For reader convenience, tables referred to in Section 2 are placed at the end of the section.
} 
the terminology of the Engineering Analysis Report. The area occupied by the wasteform facility is not included in the areas of the disposal facilities discussed in Sections 2.2 through 2.4.

Other than the wasteform facility described in Section 2.5 , the only structures in an engineered trench disposal facility are the trench disposal units themselves. The design of these trenches is assumed to be the same as described in the Engineering Analysis Report for the disposal of oxide forms of depleted uranium. Before trench excavation, the top layer of soil would be completely removed from the area, and clay would then be brought to the area and compacted to high density to construct an upper barrier wall. The compacted clay would serve two purposes: prevent the walls of a trench from collapsing or caving in and ensure that the waste is surrounded by a relatively impermeable barrier to water infiltration. Then the trench would be excavated to a depth of $8 \mathrm{~m}(26 \mathrm{ft})$. This depth would allow pallets with four drums (either 30-gallon or 55-gallon) per pallet to be stacked three high, in accordance with DOE practice. The floor of the trench would slope slightly, and along the floor's lower side a 0.6-m (2-ft) French drain would be constructed and filled with small stones. Monitoring pipes could be installed at $30-\mathrm{m}(100-\mathrm{ft})$ intervals for future sampling capabilities. Two sumps, each 1.2 by $1.2 \mathrm{~m}(3.8$ by $3.8 \mathrm{ft})$ and extending $1.2 \mathrm{~m}(3.8 \mathrm{ft})$ below the trench floor, would be constructed at $152-\mathrm{m}(500-\mathrm{ft})$ intervals and filled with sand. They would serve as collection points for water. Pervious sand would be added to the trench floor to provide (1) a firm and level base for the waste up to $1 \mathrm{~m}(3.3 \mathrm{ft})$ thick; (2) a porous medium for rainfall to move to the French drain should it rain while the trench is open; and (3) a buffer zone for an unlikely rise of the water table.

The current plan requires that one trench be opened and closed every year. This plan would result in the need for 20 trenches for the original inventory, or 25 trenches for the new inventory. A distance of $20 \mathrm{~m}(66 \mathrm{ft})$ should separate each trench to ensure stability of the trench walls and to allow room for equipment and machinery.

After a trench was full, a minimum of $0.6 \mathrm{~m}(2 \mathrm{ft})$ of clay would be added, and a 4,540-kg (10,000-lb) vibrating compactor would be used to accelerate the settling process. Topsoil overburden of at least $1 \mathrm{~m}(3.3 \mathrm{ft})$ would be added over the clay. To minimize infiltration of precipitation, all new trench cappings would be overlapped, sloped, and topped with a clay cover. To the extent practical, covers must be designed to minimize water infiltration, direct percolating or surface water away from the waste, and resist degradation by surface geologic processes and biotic activity. Surface features must direct surface water drainage away from disposal units at velocities and gradients that will not result in erosion that would require ongoing active maintenance in the future. Table 2.2 lists dimensions for the engineered trench disposal facility.

\subsection{VAULT DISPOSAL FACILITY}

The Engineering Analysis Report uses a standard below-grade design that has been modified for the circumstances of depleted uranium disposal for a vault disposal facility for the 
other disposal forms. This design is adopted for the disposal of $\mathrm{UF}_{4}$. The design considers a vault to consist of five bays, each approximately $20 \mathrm{~m}(66 \mathrm{ft})$ long by $8 \mathrm{~m}(26 \mathrm{ft})$ wide. The Engineering Analysis Report specifies that 30-gallon drums would be stacked six high, and 55-gallon drums would be stacked four high without pallets. To accommodate six levels of 30 -gallon drums, the height of a vault would have to be at least $4.5-\mathrm{m}(15-\mathrm{ft})$. The outer walls of a vault would be $0.3-\mathrm{m}$ (1-ft) thick reinforced concrete, while the inner walls between bays would be $0.3-\mathrm{m}(1-\mathrm{ft})$ thick concrete blocks. The floor of a vault would be $0.6-\mathrm{m}$ (2-ft) thick reinforced concrete over a gravel subfloor of comparable thickness. The gravel would rest on a low permeability membrane that sloped and directed infiltrated water toward a main drain (there would also be drains within the vault that led to this main drain). The main drain subsequently would flow toward a sump in one corner of the vault for leachate collection and treatment, as necessary. Monitoring pipes could be installed at 30-m (100-ft) intervals for future sampling capabilities.

A crane would be used to fill each bay with drums from the top to be consistent with the Engineering Analysis Report. Appendix D of the Engineering Analysis Report indicates that 30-gallon drums would be lowered into a bay one drum at a time. Once a level within a bay was filled, the interstitial spaces between the drums would be filled with gravel and compacted. A temporary liner would cover each bay until the entire vault was filled. Then a nominal 1-m (3-ft) thick top slab would be cast to cover the entire vault. This top slab would slope gently toward the sides, with approximately a $1 \%$ grade. Then several membrane barriers and engineered features would be put in place prior to grading and planting of vegetation. Table 2.3 shows the number of vaults needed as a function of inventory (original or new) and drum size.

\subsection{MINED-CAVITY DISPOSAL FACILITY}

A mined-cavity disposal facility is described in Section 1.5. A conceptual layout for the facility has a central drift adjacent to an access ramp from the surface. On both sides of the central drift and perpendicular to it are emplacement drifts. These drifts would be $6.5 \mathrm{~m}(21 \mathrm{ft})$ wide. The drums would be placed on pallets, four drums per pallet, and stacked two pallets high. Each pallet with 30-gallon drums would require a width of $1 \mathrm{~m}(3.3 \mathrm{ft})$. Therefore, six pallets, or 48 30-gallon drums, could be placed width-wise along a 1-m (3.3 ft) section of an emplacement

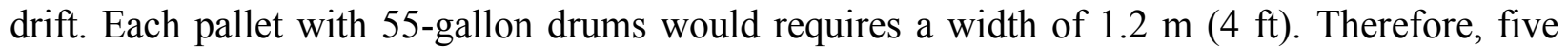
pallets, or 40 55-gallon drums, could be placed width-wise along a 1.2-m (4-ft) section of emplacement drift. On the basis of this information, the total length of emplacement drifts is shown in Table 2.4 as a function of inventory (original or new) and drum size. 


\subsection{WASTEFORM FACILITY}

The product receiving and shipping warehouse and administration building are assumed to be the same regardless of whether the disposal units are engineered trenches, vaults, or mined cavities. The size of the product receiving and shipping warehouse would depend, however, on the size and number of drums temporarily stored there. In conformity with the terminology of the Engineering Analysis Report, these two buildings are collectively referred to as the wasteform facility.

\subsubsection{Product Receiving and Shipping Warehouse}

The wasteform facility would have a building for temporary storage and inspection of drums of $\mathrm{UF}_{4}$ received at the disposal facility. The building would also house a facility for repackaging damaged drums of $\mathrm{UF}_{4}$ and shipping drums. This building is referred to as the product receiving and shipping warehouse. The entire building would be equipped with highefficiency particulate air (HEPA) filtration and served by two overhead cranes. The receiving warehouse would be designed to store drums delivered over a three-month period. Drums would be stored on pallets, four drums per pallet. A stack would be two pallets high and two pallets wide. Rows would be formed by placing four pallet stacks side-by-side. Each pallet for 30-gallon drums is assumed to be $1-\mathrm{m}(3.3-\mathrm{ft})$ wide by $1.1-\mathrm{m}(3.5-\mathrm{ft})$ long, and for 55 -gallon drums is assumed to be $1.2 \mathrm{~m}(4 \mathrm{ft})$ by $1.2 \mathrm{~m}(4 \mathrm{ft})$. There would be a $1-\mathrm{m}(3.3-\mathrm{ft})$ clearance between rows to allow for detailed inspection of the drums. Table 2.5 shows the dimensions, storage configuration, and capacity of the receiving warehouse. Undamaged drums would be moved to a loading bay for removal to a disposal unit. Damaged drums would be moved to an area for transfer of their contents to new drums.

The repackaging area would be an enclosure within the receiving warehouse building that would be kept at a slightly lower pressure than the receiving warehouse. Ingress and egress would be through air locks. The repackaging facility would contain a repackaging station for transferring $\mathrm{UF}_{4}$ from damaged drums to new drums and a storage area with empty, new drums. The damaged drums would be assumed to be LLW and would be stored pending disposal. In the product receiving area, drums would be moved by bridge crane and to or from trucks or railcars by forklift. A forklift would be used to transfer damaged drums from the receiving warehouse to the repackaging facility.

The product receiving and shipping warehouse would be a standard warehouse-type building with sheet steel for exterior walls, spread footings, and a 30-cm (1-ft) thick concrete floor. The exterior walls would have steel pillars to provide additional support for crane rails as needed. There would be no interior pillars. Steel trestles would support a standard flat roof. The heating, ventilation, and air conditioning (HVAC) system would control temperature and humidity to comfortable working levels. Once-through air flow and single filtration of exhaust 
air through HEPA filters would also be provided. Table 2.5 contains the dimensions, storage configuration, and capacity of the product receiving warehouse.

The current radioactive material license for the Envirocare disposal facility in Utah limits the amount of on-site and aboveground waste to $300,000 \mathrm{yd}^{3}\left(230,000 \mathrm{~m}^{3}\right)$ (Utah Department of Environmental Quality 2000). However, the total amount of $\mathrm{UF}_{4}$ to be disposed of would occupy only approximately $200,000 \mathrm{yd}^{3}\left(150,000 \mathrm{~m}^{3}\right)$ for the original inventory of depleted $\mathrm{UF}_{6}$ and approximately $250,000 \mathrm{yd}^{3}\left(190,000 \mathrm{~m}^{3}\right)$ for the new inventory.

\subsubsection{Administration Building}

As provided in the Engineering Analysis Report, the administration building would be located on the fenced perimeter of the site. Security offices and a security foyer would be located in the entrance to the building and adjacent to the vehicle gate so that both vehicle and personnel entry could be controlled from one station. In addition to the security function, the administration building would have office space for the site manager and for the operations, health physics, plant engineering, and maintenance supervisors and their staffs. It is important that the administration building be a structurally sound facility because this is where records would be kept and where a medical facility would be located. The administration building would have approximate dimensions of 27 by $25 \mathrm{~m}$ ( 89 by $83 \mathrm{ft}$ ) and would need to be a Performance Category 2 building. 
TABLE 2.1 Qualitative Assessment of Hazard Ranking for Disposal and Wasteform Facilities

\begin{tabular}{|c|c|c|}
\hline Building/Area & Hazard Ranking/Category & Qualitative Rationale \\
\hline Administration & None/Performance Category 2 & $\begin{array}{l}\text { Facilities must continue to function after a } \\
\text { seismic event or an accident }\end{array}$ \\
\hline $\begin{array}{l}\text { Product receiving and } \\
\text { shipping warehouse }\end{array}$ & Low/Performance Category 2 & Minimal off-site and on-site releases \\
\hline Engineered trenches & Low/Performance Category 2 & $\begin{array}{l}\text { No off-site release, minimal on-site } \\
\text { releases, essential to mission }\end{array}$ \\
\hline Vault & Low/Performance Category 2 & $\begin{array}{l}\text { No off-site release, minimal on-site } \\
\text { releases, essential to mission }\end{array}$ \\
\hline Mined-cavity & Low/Performance Category 2 & $\begin{array}{l}\text { No off-site release, minimal on-site } \\
\text { releases, essential to mission }\end{array}$ \\
\hline
\end{tabular}

TABLE 2.2 Dimensions for the Engineered Trench Disposal Facility

\begin{tabular}{ccccccc}
\hline \multirow{2}{*}{ Parameter } & \multicolumn{2}{c}{ Original Inventory } & & \multicolumn{2}{c}{ New Inventory } \\
\cline { 2 - 3 } \cline { 5 - 6 } & $\begin{array}{c}30 \text {-Gallon } \\
\text { Drums }\end{array}$ & $\begin{array}{c}\text { 55-Gallon } \\
\text { Drums }\end{array}$ & & $\begin{array}{c}\text { 30-Gallon } \\
\text { Drums }\end{array}$ & $\begin{array}{c}55 \text {-Gallon } \\
\text { Drums }\end{array}$ \\
\hline Facility length (m) & 344 & 344 & & 427 & 427 \\
Facility width (m) & 597 & 506 & & 597 & 506 \\
\hline
\end{tabular}

TABLE 2.3 Number of Vaults Needed for Vault Disposal Facility

\begin{tabular}{lcc}
\hline Drum Size & Original Inventory & New Inventory \\
\hline 30-gallon & 76 & 95 \\
55-gallon & 84 & 105 \\
\hline
\end{tabular}


TABLE 2.4 Total Length of Emplacement Drifts Needed for Mined-Cavity Disposal Facility

\begin{tabular}{ccc} 
Drum Size & Original Inventory & New Inventory \\
\hline 30-gallon & $28,700 \mathrm{~m}$ & $38,428 \mathrm{~m}$ \\
55 -gallon & $22,830 \mathrm{~m}$ & $28,743 \mathrm{~m}$ \\
\hline
\end{tabular}

TABLE 2.5 Dimensions, Storage Configuration, and Capacity of the Product Receiving Warehouse

\begin{tabular}{ccccccc}
\hline Drum Size & Inventory & Length $(\mathrm{m})$ & Width $(\mathrm{m})$ & $\begin{array}{c}\text { Number of } \\
\text { Rows }\end{array}$ & $\begin{array}{c}\text { Containers } \\
\text { per Row }\end{array}$ & $\begin{array}{c}\text { Containers, } \\
\text { Building } \\
\text { Capacity }\end{array}$ \\
\hline 30-gallon & Original & 65 & 63 & 20 & 858 & 17,163 \\
55-gallon & Original & 56 & 55 & 15 & 624 & 9,363 \\
30-gallon & New & 66 & 63 & 20 & 864 & 17,290 \\
55 -gallon & New & 56 & 55 & 15 & 632 & 9,430 \\
\hline
\end{tabular}




\section{DISPOSAL SITE LAND USE REQUIREMENTS}

The land use requirements for the disposal facility were developed with a methodology consistent with that used in the Engineering Analysis Report for the other depleted uranium waste forms. Those waste forms must be processed before they can be disposed of, and it was assumed that the processing was done on the disposal facility site. For some contexts, the Engineering Analysis Report lumped the administration building, product receiving building, supply and shipping building and several process buildings into a facility called the wasteform facility. To be consistent with the terminology of the Engineering Analysis Report, the administration building and product receiving and shipping warehouse will be referred here to collectively as the wasteform facility when appropriate.

The design assumes a reasonable industrial site is selected. Access to an all-weather road suitable for use by a maximum legal weight semi-tractor is essential. Access to a rail spur is optional. Utilities assumed to be available at the site are electricity, natural gas, potable water, and sanitary sewer. Telephone service would also be required. The approach assumes that clearing and grading would be limited to those areas immediately surrounding the planned locations of the buildings and disposal facilities. These assumptions are consistent with the disposal site being either the Nevada Test Site or the Envirocare site in Utah.

\subsection{ENGINEERED TRENCH DISPOSAL FACILITY}

In the Engineering Analysis Report, it is assumed that 55-gallon drums with cementencapsulated $\mathrm{U}_{3} \mathrm{O}_{8}$ would be emplaced in trenches that are $8 \mathrm{~m}(26 \mathrm{ft})$ deep and $61 \mathrm{~m}(200 \mathrm{ft})$ wide. The length of a trench is determined from the number of drums disposed of per year, based on the assumption that the drums are on four-drum pallets stacked three high. It was also

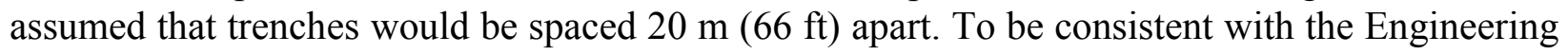
Analysis Report, the same assumptions are used here. For disposal in 30-gallon drums, a pallet would have dimensions of 1 by $1.1 \mathrm{~m}(3.3 \mathrm{by} 3.6 \mathrm{ft})$. The width of a trench could accommodate 61 pallets. Therefore, 732 drums could be disposed of in a 61-m (200-ft) width of trench (one row). For disposal in 55-gallon drums, a pallet would have dimensions of 1.2 by $1.2 \mathrm{~m}$ ( 4 by $4 \mathrm{ft}$ ) and the width of a trench could accommodate 50 pallets. Therefore, 600 drums could be disposed of in a $61-\mathrm{m}(200-\mathrm{ft})$ width of trench.

It is assumed that drums would be emplaced in one trench per year and that emplacement would take place over a 20 -year period for the original inventory and over a 25 -year period for the new inventory. The number of rows is calculated from the number of drums that must be disposed of in a year (see Table 1.6) and the number of drums in a row. The length of a trench is calculated from the length of a row and the number of rows. For the original inventory, the length of a trench would be $93.9 \mathrm{~m}$ (308 ft) for disposal in 30-gallon drums, or $76.2 \mathrm{~m}(250 \mathrm{ft})$ 
for disposal in 55-gallon drums. For the new inventory, the length of a trench would be $94.5 \mathrm{~m}$

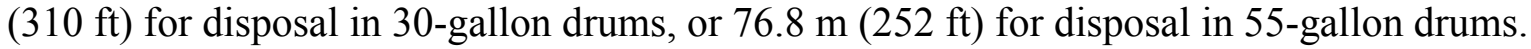

Trenches would be excavated in a 4 by 5 array for the original inventory, or in a 5 by 5 array for the new inventory, with $20.1 \mathrm{~m}(66 \mathrm{ft})$ separating each trench. Also, there would be a 20.1-m separation between the outer trenches and the boundary of the disposal facility. The resulting land parameters are given in Table $3.1 \mathrm{a}^{1}$ for disposal of the original inventory in 30-gallon drums, in Table 3.1b for disposal of the new inventory in 30-gallon drums, in Table 3.2a for disposal of the original inventory in 55-gallon drums, and in Table 3.2b for disposal of the new inventory in 55-gallon drums. Figures 3.1a and 3.1b illustrate the facility layout on the basis of the new inventory, for 30-gallon and 55-gallon drums, respectively.

\subsection{VAULT DISPOSAL FACILITY}

To be consistent with the Engineering Analysis Report, it is assumed that vaults would be divided into five bays, each approximately $20.6 \mathrm{~m}(68 \mathrm{ft})$ long by $8 \mathrm{~m}(26 \mathrm{ft})$ wide. The Engineering Analysis Report assumed that 30-gallon drums would be emplaced individually (rather than on pallets), with 3,655 drums per bay with six levels of drums. To accommodate six levels of 30-gallon drums, each with a height of $74 \mathrm{~cm} \mathrm{(29} \mathrm{in.),} \mathrm{the} \mathrm{height} \mathrm{of} \mathrm{a} \mathrm{vault} \mathrm{must} \mathrm{be} \mathrm{at}$ least $4.5 \mathrm{~m}(15 \mathrm{ft})$. The capacity of a vault would then be 18,275 drums. Because $1,373,000$ drums would be disposed of for the original inventory, 76 vaults would be needed. For the new inventory, 95 vaults would be needed to dispose of 1,729,000 drums. The Engineering Analysis Report assumed that 55-gallon drums would be emplaced five high in the bays, 1,800 drums per bay, or 9,000 drums per vault. For the original inventory, 84 vaults would be required for disposal of 749,000 drums; for the new inventory, 105 vaults would be required to dispose of 943,000 drums.

As in the Engineering Analysis Report, it was assumed for this report that the disposal area would be organized into 10-vault blocks. Each block would have two rows of five vaults (five columns) except the last block, which would have fewer vaults. For example, disposal of the original inventory in 30-gallon drums would require seven 10-vault blocks and one 6-vault block. A paved, 10-m (33-ft) wide road would surround each block. The distance between rows would be $22.5 \mathrm{~m}(74 \mathrm{ft})$, while the distance between columns would be $20 \mathrm{~m}(66 \mathrm{ft})$. The overall dimensions of each 10-vault block would thus be $215 \mathrm{~m}(705 \mathrm{ft})$ by $125.6 \mathrm{~m}(412 \mathrm{ft})$. The area associated with one block is then 2.7 hectares ( 6.8 acres), excluding the roadways. The resulting land parameters are given in Table 3.1a for disposal of the original inventory in 30-gallon drums, in Table $3.1 \mathrm{~b}$ for disposal of the new inventory in 30-gallon drums, in Table 3.2a for disposal of the original inventory in 55-gallon drums, and in Table 3.2b for disposal of the new inventory in 55-gallon drums. Figures $3.2 \mathrm{a}$ and $3.2 \mathrm{~b}$ illustrate the facility layout on the basis of the new inventory, for 30-gallon and 55-gallon drums, respectively.

\footnotetext{
${ }^{1}$ For reader convenience, tables and figures referred to in Section 3 are place at the end of the section.
} 


\subsection{MINED-CAVITY DISPOSAL FACILITY}

The general layout of a mined-cavity disposal facility for depleted $\mathrm{UF}_{4}$ is described in the Engineering Analysis Report for the other waste forms. The same general layout is assumed here. Three main drifts would bisect the underground area: (1) the waste main, connected to the surface by the waste ramp; (2) the rock main, connected to the surface by the rock ramp; and (3) the service main. Intersecting these mains at right angles would be the emplacement drifts. The emplacement drifts are assumed to have a width of $6.5 \mathrm{~m}(21 \mathrm{ft})$ and to be spaced $32 \mathrm{~m}$ $(105 \mathrm{ft})$. To be consistent with the Engineering Analysis Report, it is assumed that 30-gallon drums would be emplaced in a drift on four-drum pallets stacked two high. Because the size of a pallet would be 1 by $1.1 \mathrm{~m}$ (3.3 by $3.6 \mathrm{ft})$, a drift would be six pallets wide. Therefore, a $1-\mathrm{m}$ (3.3-ft) section of drift could accommodate disposal of 48 drums. If 55-gallon drums were used, the width of a drift could accommodate five 4-drum pallets. Therefore, a 1.22-m (4-ft) section of drift could accommodate 40 drums. If 30-gallon drums were used, the total emplacement drift lengths required would be $30,515 \mathrm{~m}(100,115 \mathrm{ft})$ for the original inventory and $38,428 \mathrm{~m}$ $(126,076 \mathrm{ft})$ for the new inventory. If 55-gallon drums were used, the total emplacement drift lengths required would be $22,830 \mathrm{~m}(74,900 \mathrm{ft})$ for the original inventory and $28,743 \mathrm{~m}$ $(94,300 \mathrm{ft})$ for the new inventory.

The resulting land parameters are given in Table 3.1a for disposal of the original inventory in 30-gallon drums, in Table $3.1 \mathrm{~b}$ for disposal of the new inventory in 30-gallon drums, in Table 3.2a for disposal of the original inventory in 55-gallon drums, and in Table 3.2b for disposal of the new inventory in 55-gallon. Figures $3.3 \mathrm{a}$ and $3.3 \mathrm{~b}$ illustrate the facility layout on the basis of the new inventory, for 30-gallon and 55-gallon drums, respectively.

\subsection{WASTEFORM FACILITY}

The wasteform facility would consist of the product receiving and shipping warehouse and the administration building. The wasteform facility would be inside a fence. The product receiving part of the warehouse would be adjacent to a rail spur or a road for the delivery of waste inventory. The shipping part of this building would have a portal for loading pallets of drums on trucks for transport to the disposal units. The wasteform facility building footprint areas are given in Table 3.3, and the site land parameters are given in Table 3.4. Figures 3.4a and $3.4 \mathrm{~b}$ illustrate the facility layout on the basis of the new inventory, for 30-gallon and 55-gallon drums, respectively. 
TABLE 3.1a Site Land Parameters for Disposal of Original Inventory in 30-Gallon Drums

\begin{tabular}{lccc}
\hline \multicolumn{1}{c}{ Parameter } & Engineered Trench & Vaults & Mine \\
\hline & & & \\
Site land area, ha & 20.6 & 25.4 & 236 \\
Disturbed land area, ha & 18.7 & 25.4 & 236 \\
Total fenced area, ha & 20.6 & 25.4 & 236 \\
Total paved area, ha & 0.9 & 3.5 & 12 \\
Total excavated material, $\mathrm{m}^{3}$ & $1.29 \mathrm{E}+06$ & $5.71 \mathrm{E}+05$ & $1.22 \mathrm{E}+06$ \\
Facility length, m & 597 & 552 & 1,586 \\
Facility width, m & 344 & 460 & 1,560 \\
Underground site land area, ha & & & 247 \\
\hline
\end{tabular}

TABLE 3.1b Site Land Parameters for Disposal of New Inventory in 30-Gallon Drums

\begin{tabular}{lccc}
\hline \multicolumn{1}{c}{ Parameter } & Engineered Trench & Vaults & Mine \\
\hline & & & \\
Site land area, ha & 25.5 & 31.6 & 310 \\
Disturbed land area, ha & 23.4 & 31.6 & 310 \\
Total fenced area, ha & 25.5 & 31.6 & 310 \\
Total paved area, ha & 1.0 & 4.4 & 12 \\
Total excavated material, $\mathrm{m}^{3}$ & $1.65 \mathrm{E}+06$ & $7.14 \mathrm{E}+05$ & $1.44 \mathrm{E}+06$ \\
Facility length, m & 597 & 688 & 1,740 \\
Facility width, m & 427 & 460 & 1,782 \\
Underground site land area, ha & & & 310 \\
\hline
\end{tabular}

TABLE 3.2a Site Land Parameters for Disposal of Original Inventory in 55-Gallon Drums

\begin{tabular}{lccc}
\hline \multicolumn{1}{c}{ Parameter } & Engineered Trench & Vaults & Mine \\
\hline & & & \\
Site land area, ha & 17.4 & 31.6 & 168 \\
Disturbed land area, ha & 15.7 & 31.6 & 168 \\
Total fenced area, ha & 17.4 & 31.6 & 168 \\
Total paved area, ha & 0.8 & 4.4 & 11 \\
Total excavated material, $\mathrm{m}^{3}$ & $1.06 \mathrm{E}+06$ & $6.31 \mathrm{E}+05$ & $9.91 \mathrm{E}+05$ \\
Facility length, m & 506 & 688 & 1,355 \\
Facility width, m & 344 & 460 & 1,378 \\
Underground site land area, ha & & & 187 \\
\hline
\end{tabular}


TABLE 3.2b Site Land Parameters for Disposal of New Inventory in 55-Gallon Drums

\begin{tabular}{lccc}
\hline \multicolumn{1}{c}{ Parameter } & Engineered Trench & Vaults & Mine \\
\hline & & & \\
Site land area, ha & 21.6 & 37.9 & 220 \\
Disturbed land area, ha & 19.7 & 37.9 & 220 \\
Total fenced area, ha & 21.6 & 37.9 & 220 \\
Total paved area, ha & 0.9 & 5.2 & 12 \\
Total excavated material, $\mathrm{m}^{3}$ & $1.36 \mathrm{E}+06$ & $7.89 \mathrm{E}+05$ & $1.16 \mathrm{E}+06$ \\
Facility length, m & 506 & 824 & 1,509 \\
Facility width, m & 427 & 460 & 1,548 \\
Underground site land area, ha & & & 234 \\
\hline
\end{tabular}

TABLE 3.3 Wasteform Facility Building Footprint Areas

\begin{tabular}{lcccccc}
\hline & \multicolumn{2}{c}{ Original Inventory } & & \multicolumn{2}{c}{ New Inventory } \\
\cline { 2 - 3 } \multicolumn{1}{c}{ Building } & $\begin{array}{c}\text { 30-Gallon } \\
\text { Drums }\end{array}$ & $\begin{array}{c}\text { 55-Gallon } \\
\text { Drums }\end{array}$ & & & $\begin{array}{c}\text { 30-Gallon } \\
\text { Drums }\end{array}$ & $\begin{array}{c}\text { 55-Gallon } \\
\text { Drums }\end{array}$ \\
\hline $\begin{array}{l}\text { Product receiving and } \\
\text { shipping warehouse, } \mathrm{m}^{2}\end{array}$ & 4,100 & 3,100 & & 4,200 & 3,100 \\
Administration building, $\mathrm{m}^{2}$ & 675 & 675 & & 675 & 675 \\
Total, $\mathrm{m}^{2}$ & 4,776 & 3,776 & & 4,876 & 3,776 \\
\hline
\end{tabular}

TABLE 3.4 Site Land Parameters at the Wasteform Facility

\begin{tabular}{|c|c|c|c|c|}
\hline \multirow[b]{2}{*}{ Parameter } & \multicolumn{2}{|c|}{ Original Inventory } & \multicolumn{2}{|c|}{ New Inventory } \\
\hline & $\begin{array}{c}\text { 30-Gallon } \\
\text { Drums }\end{array}$ & $\begin{array}{c}\text { 55-Gallon } \\
\text { Drums }\end{array}$ & $\begin{array}{c}\text { 30-Gallon } \\
\text { Drums }\end{array}$ & $\begin{array}{c}\text { 55-Gallon } \\
\text { Drums }\end{array}$ \\
\hline Site land area, ha & 1.7 & 1.4 & 1.7 & 1.4 \\
\hline Disturbed land area, ha & 1.7 & 1.4 & 1.7 & 1.4 \\
\hline Total fenced area, ha & 1.6 & 1.3 & 1.6 & 1.3 \\
\hline Total paved area, ha & 0.33 & 0.28 & 0.34 & 0.28 \\
\hline Total excavated material, $\mathrm{m}^{3}$ & 9,550 & 7,550 & 9,750 & 7,550 \\
\hline
\end{tabular}




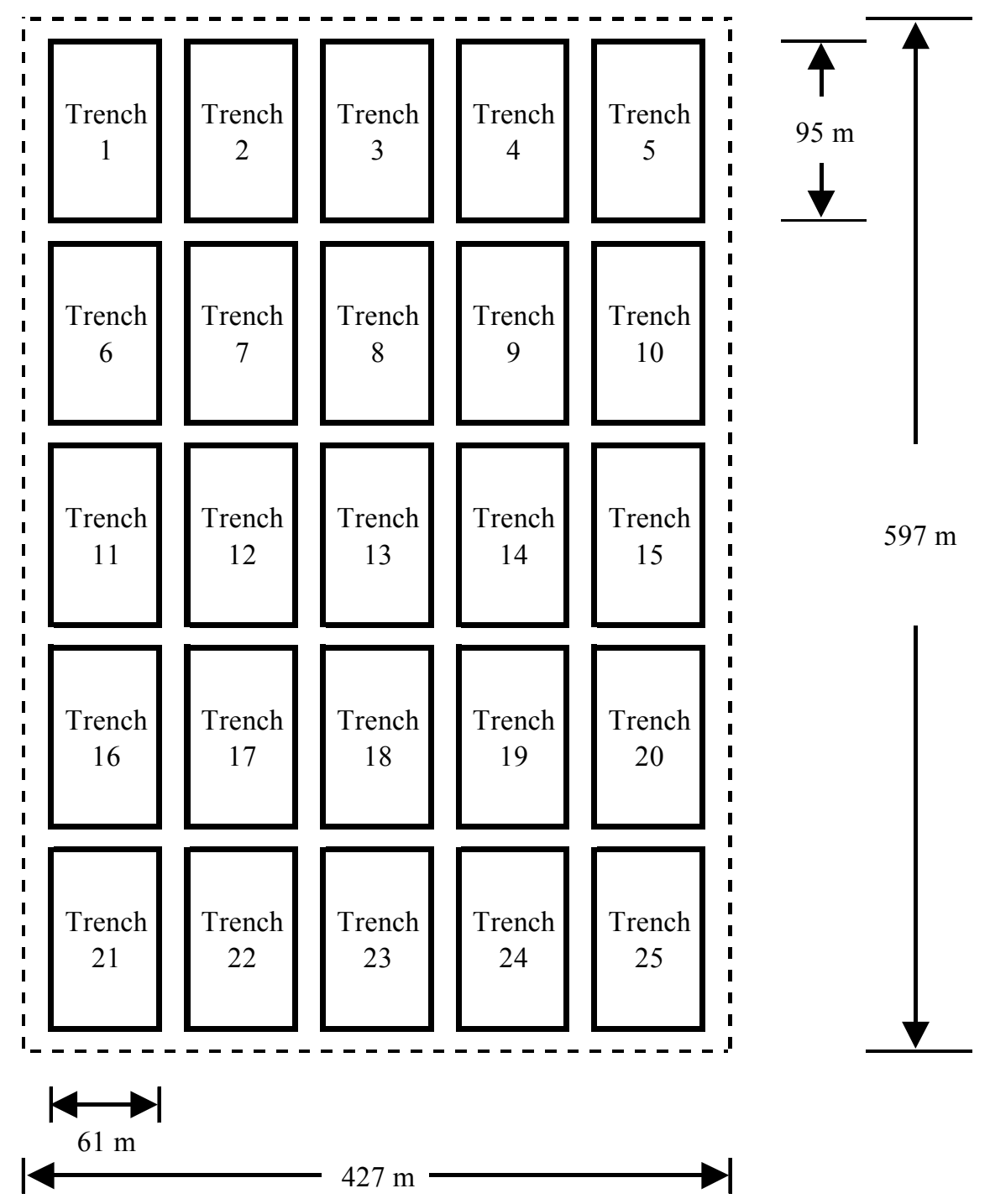

FIGURE 3.1a Site Map and Land Area for Operation of the Engineered Trench Disposal Facility: New Inventory, 30-Gallon Drums (not to scale) 


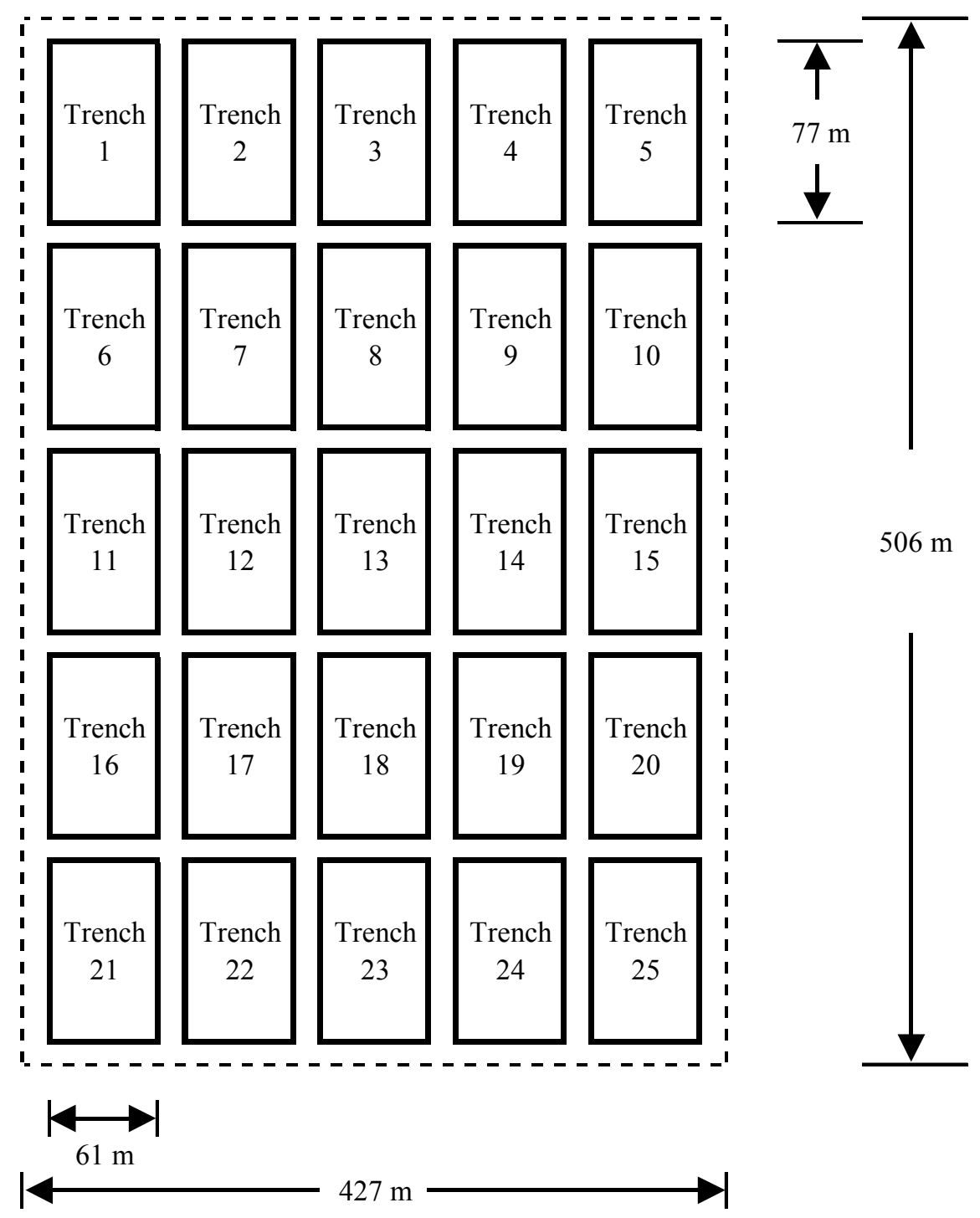

FIGURE 3.1b Site Map and Land Area for Operation of the Engineered Trench Disposal Facility: New Inventory, 55-Gallon Drums (not to scale) 


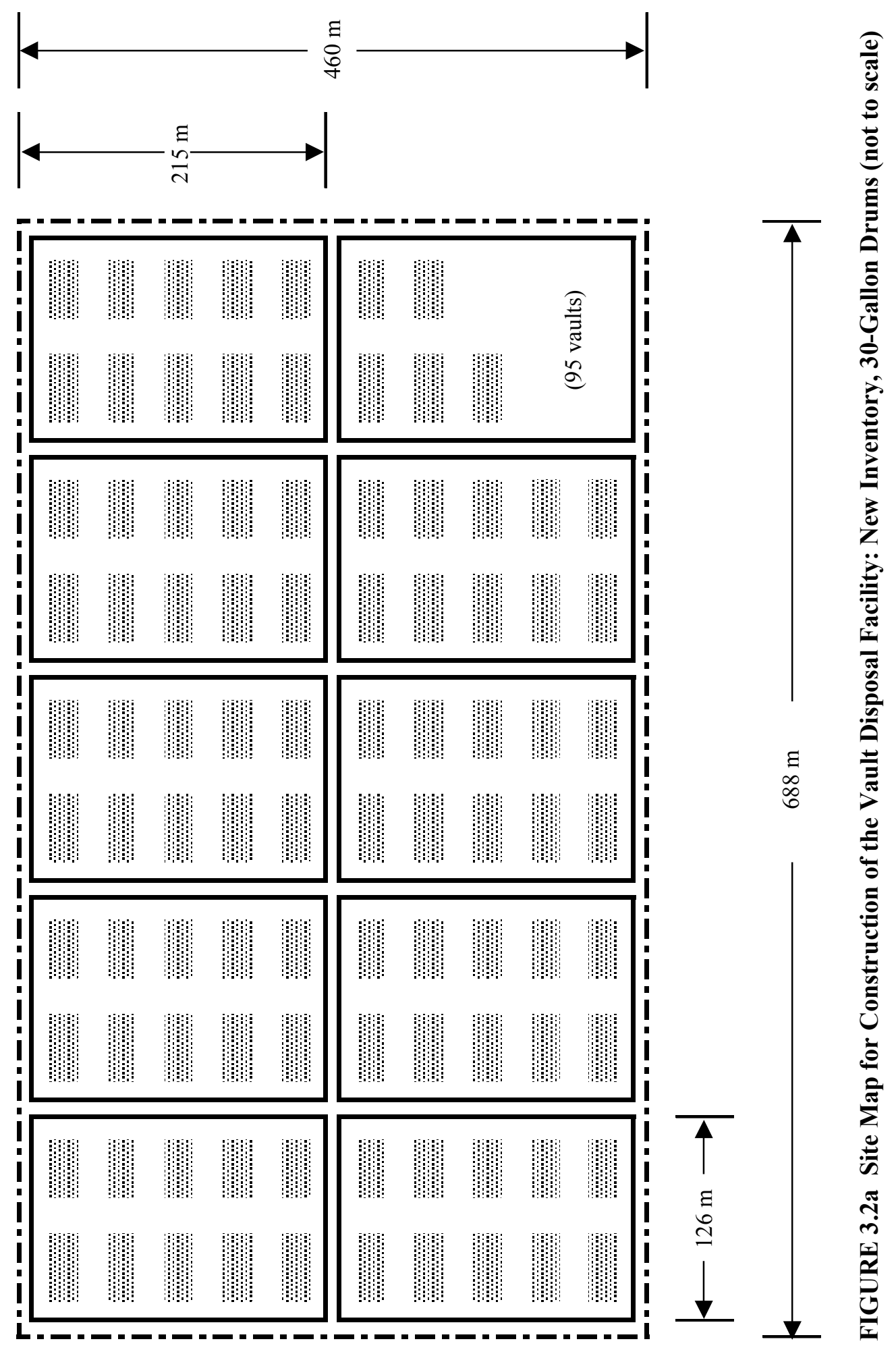




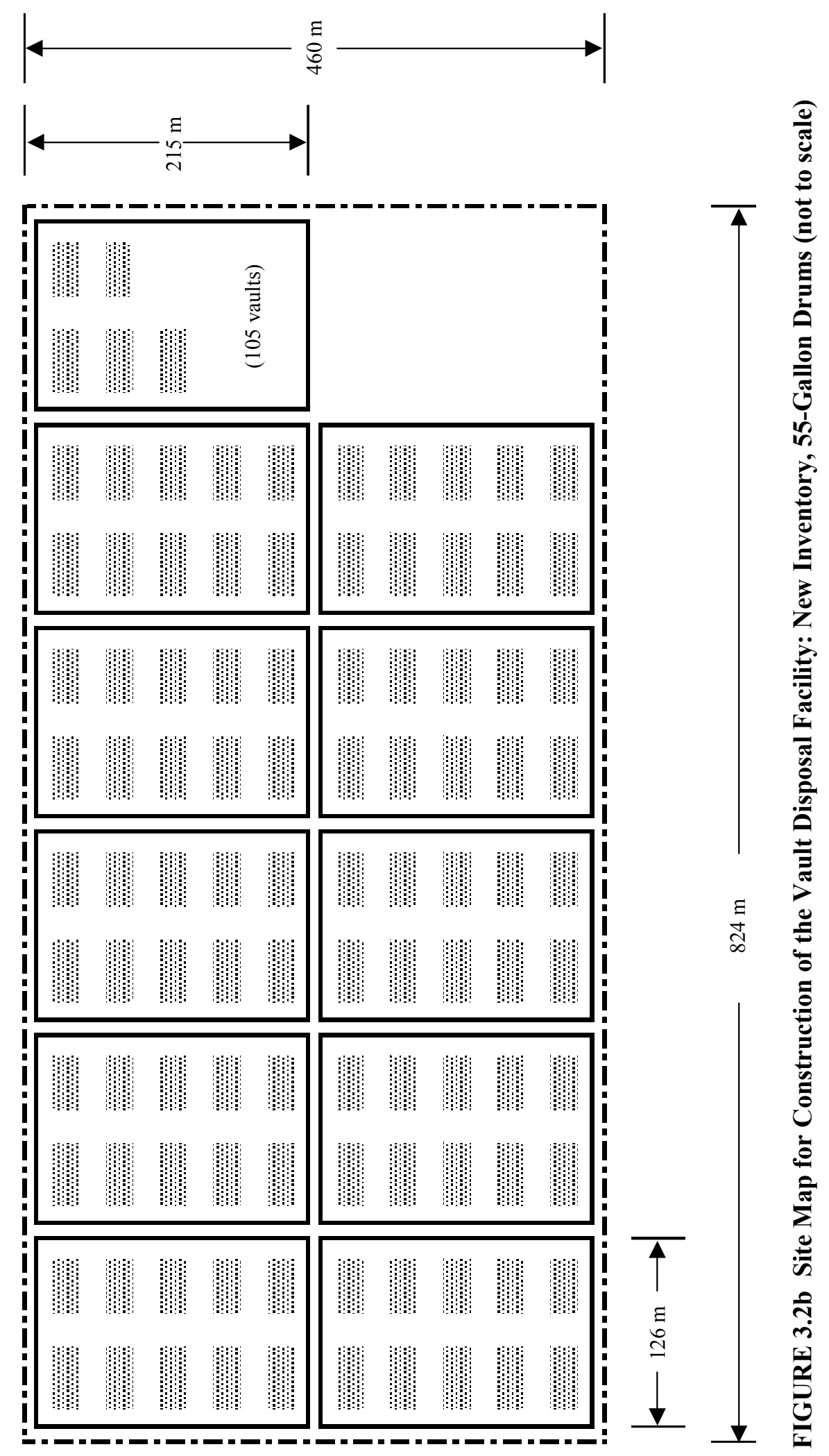




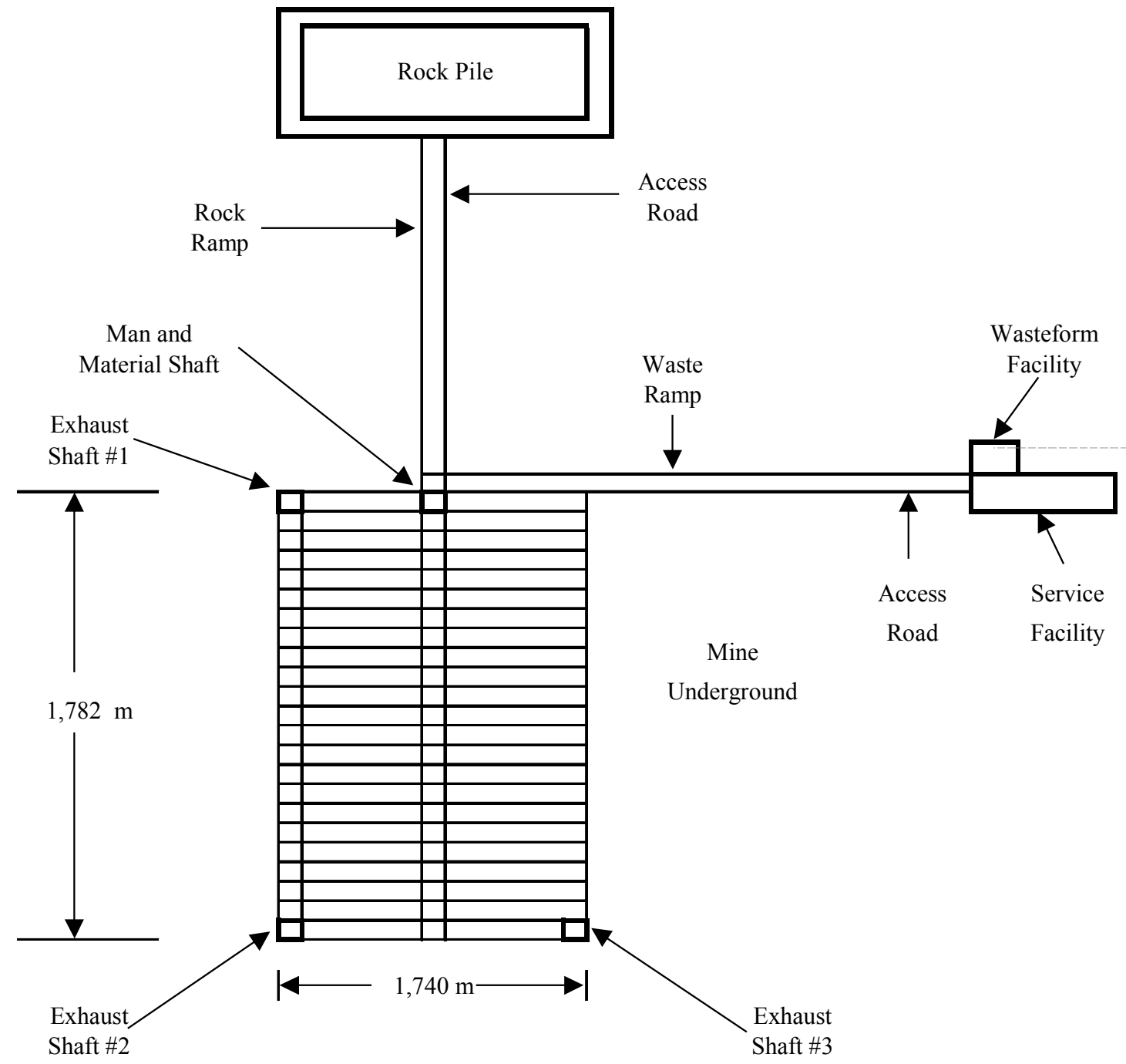

FIGURE 3.3a Site Map and Land Area during Operation of the Mined-Cavity Disposal Facility: New Inventory, 30-Gallon Drums (not to scale) 


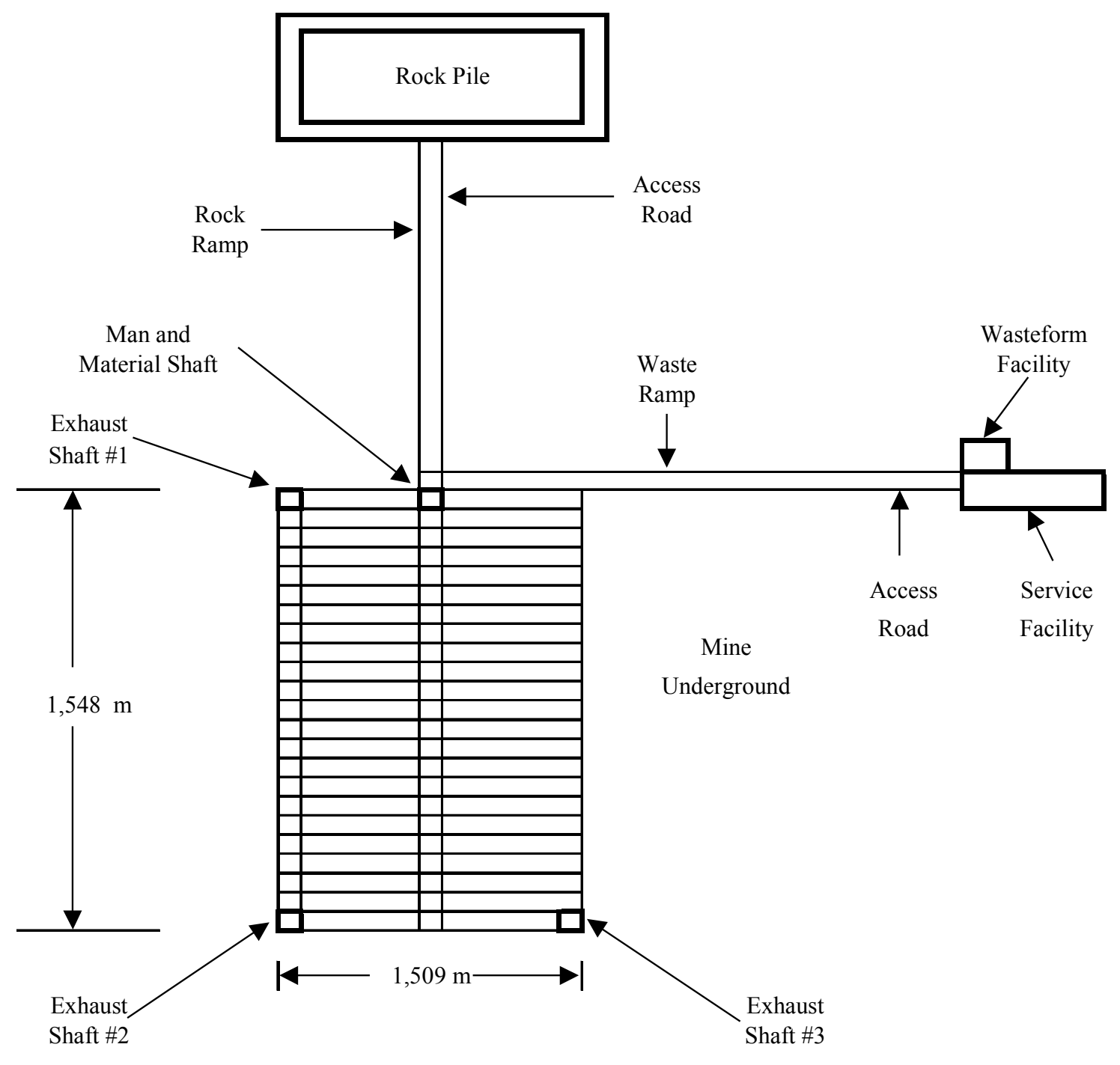

FIGURE 3.3b Site Map and Land Area during Operation of the Mined-Cavity Disposal Facility: New Inventory, 55-Gallon Drums (not to scale) 


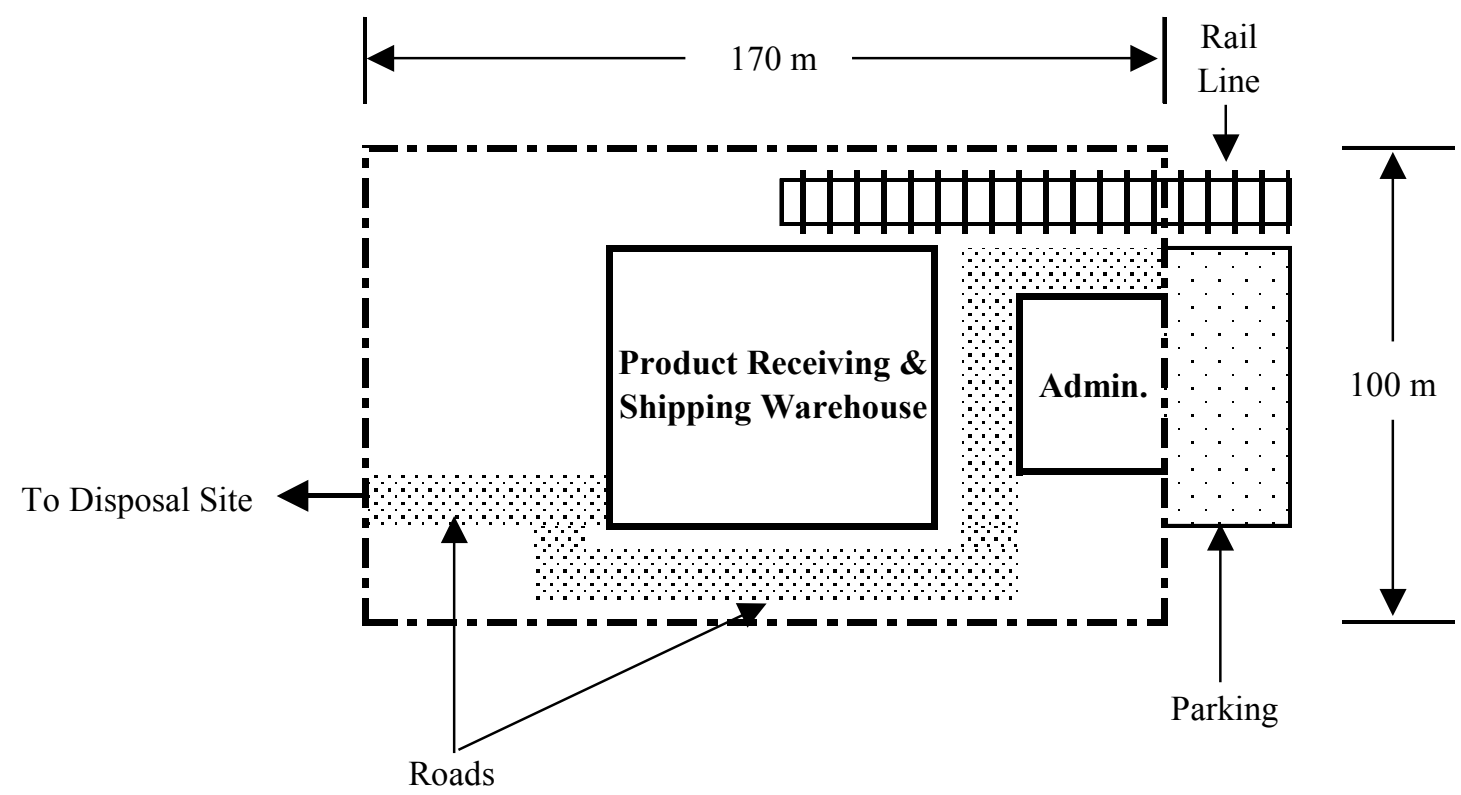

FIGURE 3.4a Site Map during Operation of the Wasteform Facility: New Inventory, 30-Gallon Drums (not to scale)

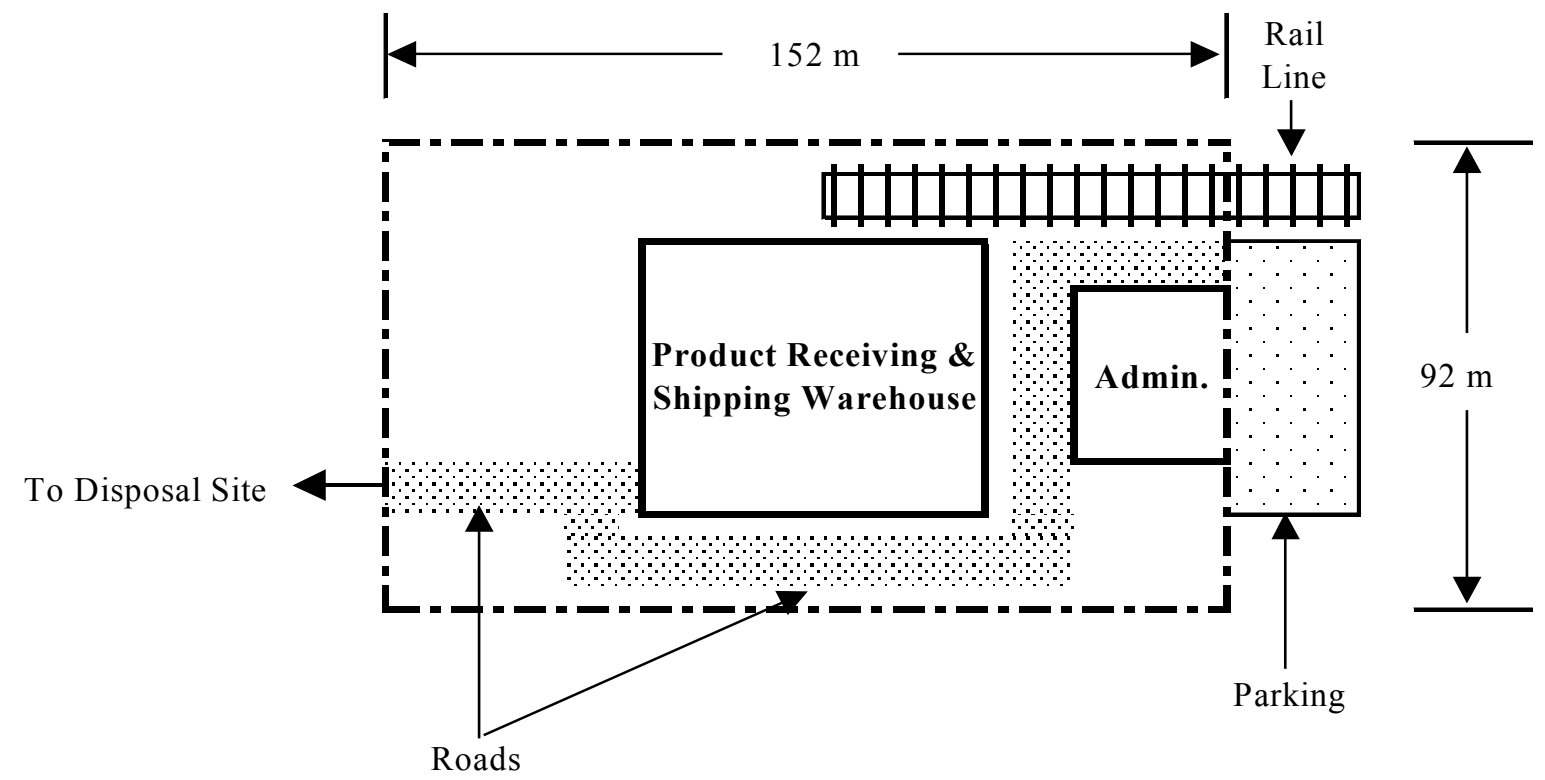

FIGURE 3.4b Site Map during Operation of the Wasteform Facility: New Inventory, 55-Gallon Drums (not to scale) 


\section{RESOURCE NEEDS}

Resources needed for the construction and operation of a depleted uranium disposal facility are divided into two classes: materials and utilities. Materials are the substances used to construct the disposal units, such as sand, clay, gravel, and Redi-Mix concrete. This category also includes the materials excavated from the trenches, vaults, or mined cavities. Utilities include electricity, natural gas, water, and diesel fuel. Materials would be consumed only by construction activities. Utilities would be consumed both by construction activities and operations.

Operations activities would include receiving drums of waste, inspecting them, repacking them if necessary, transporting the drums to disposal units, and emplacing them. To some extent, construction activities and operational activities would be concurrent. For example, one trench would be in the process of being filled while another was being constructed. However, the disposal facility would not be abandoned once all the depleted uranium had been emplaced and the facility had undergone closure. For example, the NRC in 10 CFR 61.59 requires a period of institutional control, which cannot be relied on for more than 100 years. An institutional control program should include physical control of access to the site, an environmental monitoring program, periodic surveillance, and custodial care. The use of utilities would be much greater during the operational period than during the period of institutional control. Therefore, utility use during the institutional control period is not considered here, consistent with the Engineering Analysis Report. However, the workforce utilized during the maintenance period is estimated in Appendix B.

\subsection{ENGINEERED TRENCH DISPOSAL FACILITY}

The one factor that is most likely to affect the containment capability of an engineered trench disposal facility is the degree to which groundwater and surface water can contact the waste and subsequently cause migration of radionuclides. An effective way to avoid such contact is to place a permanent water-resistant cover over the trenches to restrict percolation of surface water through the waste. Clay, soil additives, asphalt, plastic membranes, concrete, and stainless steel could be used for this protective cover. To be consistent with the Engineering Analysis Report, it is assumed here that clay would be used for this protective cover.

During construction, water (mainly for personnel usage), diesel fuel, electricity, and trench material would be needed. During operations, water needs would be primarily for potable water for site personnel. Wastewater in the form of sanitary waste would be generated by site personnel. Diesel fuel and electricity would be used by emplacement equipment. Tables 4.1a and $4.1 \mathrm{~b}^{1}$ show estimates of the materials and resources required for construction of an engineered trench facility for the disposal of $\mathrm{UF}_{4}$ for the original inventory and new inventory,

\footnotetext{
${ }^{1}$ For reader convenience, tables referred to in Section 4 are placed at the end of the section.
} 
respectively. Tables $4.2 \mathrm{a}$ and $4.2 \mathrm{~b}$ show estimates of the materials and resources required for routine operation of an engineered trench facility for the original inventory and the new inventory, respectively.

\subsection{VAULT DISPOSAL FACILITY}

Tables $4.3 \mathrm{a}$ and $4.3 \mathrm{~b}$ summarize materials and resources consumed during construction of a vault disposal facility for the original inventory and the new inventory, respectively. Tables 4.4a and 4.4b summarize materials and resources consumed during routine operation of a vault disposal facility for the original inventory and the new inventory, respectively. Diesel fuel would be required for trucks and emplacement cranes. Concrete would be used for constructing and sealing the vaults.

\subsection{MINED-CAVITY DISPOSAL FACILITY}

A major material associated with a mined-cavity disposal facility would be the rock excavated from the underground area to provide for (1) the three main drifts for services, tuff movement, and waste movement; (2) a perimeter drift that would encircle the underground area; (3) the emplacement drifts; (4) ramps connecting the rock and waste drifts with the surface; and (5) shafts drilled from the surface to the underground area to provide access for workers, materials, and utilities.

Considerable diesel fuel and electricity would be expended in excavating a mined-cavity disposal facility. The walls of all drifts and ramps would have to be lined with steel-reinforced concrete, which is shot in place. This process requires in situ mixing of the concrete components, including water. Tables $4.5 \mathrm{a}$ and $4.5 \mathrm{~b}$ summarize material used to construct a mined-cavity disposal facility for the original inventory and the new inventory, respectively.

In accordance with the Engineering Analysis Report, it is assumed here that the mined-cavity disposal facility would operate on a one shift per day basis over a 20-year period for the original inventory and over a 25 -year period for the new inventory. The principal utility required would be electric power for operation of ventilation systems, industrial power equipment (e.g., forklifts), and for lighting and heating. Tables 4.6a and 4.6b summarize utilities needed for operations of a mined-cavity disposal facility for the original inventory and the new inventory, respectively. 


\subsection{WASTEFORM FACILITY}

Estimates of materials and resources used during construction and operation of the wasteform facility follow the methodology used in the Engineering Analysis Report. Tables 4.7a and $4.7 \mathrm{~b}$ summarize the estimates of resource requirements during construction of the wasteform facility using approximate, order of magnitude values for the original inventory and the new inventory, respectively. Tables $4.8 \mathrm{a}$ and $4.8 \mathrm{~b}$ present estimates of the amount of concrete used for each building that makes up the wasteform facility. Tables $4.9 \mathrm{a}$ and $4.9 \mathrm{~b}$ present the estimated resource requirements for operation of the facility. The wasteform facility would be larger for the new inventory than for the original inventory when 30-gallon drums would be used, but not when 55-gallon drums would be used. This situation arises because there would be an addition row of pallets of 30-gallon stored in the product receiving and shipping warehouse for the new inventory, but not an additional row of pallets of 55-gallon drums. 
TABLE 4.1a Materials and Resources Required during Construction of Engineered Trenches, Original Inventory

\begin{tabular}{|c|c|c|c|c|}
\hline \multirow[b]{2}{*}{ Item } & \multicolumn{2}{|c|}{ 30-Gallon Disposal Containers } & \multicolumn{2}{|c|}{ 55-Gallon Disposal Containers } \\
\hline & Annually & Over 20 Years & Annually & Over 20 Years \\
\hline Water, ML & 0.014 & 0.28 & 0.014 & 0.27 \\
\hline Excavated material, $\mathrm{m}^{3}$ & $6.44 \mathrm{E}+04$ & $1.29 \mathrm{E}+06$ & $5.32 \mathrm{E}+04$ & $1.06 \mathrm{E}+06$ \\
\hline Clay, $\mathrm{m}^{3}$ & 437 & 8,740 & 392 & 7,840 \\
\hline Sand, $\mathrm{m}^{3}$ & 2,910 & $5.83 \mathrm{E}+04$ & 2,340 & $4.69 \mathrm{E}+04$ \\
\hline Gravel, te & 122 & 2,440 & 99 & 1,970 \\
\hline Electricity, MW-h & 220 & 4,410 & 185 & 3,700 \\
\hline Diesel fuel, L & $5.68 \mathrm{E}+04$ & $1.14 \mathrm{E}+06$ & $4.69 \mathrm{E}+04$ & $9.38 \mathrm{E}+05$ \\
\hline
\end{tabular}

TABLE 4.1b Materials and Resources Required during Construction of Engineered Trenches, New Inventory

\begin{tabular}{|c|c|c|c|c|}
\hline \multirow[b]{2}{*}{ Item } & \multicolumn{2}{|c|}{ 30-Gallon Disposal Containers } & \multicolumn{2}{|c|}{ 55-Gallon Disposal Containers } \\
\hline & Annually & Over 25 Years & Annually & Over 25 Years \\
\hline Water, ML & 0.12 & 0.29 & 0.011 & 0.28 \\
\hline Excavated material, $\mathrm{m}^{3}$ & $6.58 \mathrm{E}+04$ & $1.65 \mathrm{E}+06$ & $5.44 \mathrm{E}+04$ & $1.36 \mathrm{E}+06$ \\
\hline Clay, $\mathrm{m}^{3}$ & 452 & 11,300 & 406 & $1.01 \mathrm{E}+04$ \\
\hline Sand, $\mathrm{m}^{3}$ & 3,060 & $7.65 \mathrm{E}+04$ & 2,480 & $6.20 \mathrm{E}+04$ \\
\hline Gravel, te & 128 & 3,200 & 104 & 2,600 \\
\hline Electricity, MW-h & 222 & 5,560 & 186 & 4,640 \\
\hline Diesel fuel, L & $5.82 \mathrm{E}+04$ & $1.45 \mathrm{E}+06$ & $4.81 \mathrm{E}+04$ & $1.20 \mathrm{E}+06$ \\
\hline
\end{tabular}

TABLE 4.2a Resources Required during Operation of the Engineered Trench Disposal Facility, Original Inventory

\begin{tabular}{lrrrrr}
\hline & \multicolumn{3}{c}{ 30-Gallon Disposal Containers } & & \multicolumn{2}{c}{ 55-Gallon Disposal Containers } \\
\cline { 2 - 3 } \multicolumn{1}{c}{ Item } & Annually & Over 20 Years & & Annually & Over 20 Years \\
\hline & & & & & \\
Water, ML & 0.083 & 1.66 & & 0.052 & 1.04 \\
Electricity, MW-h & 1,030 & $2.06 \mathrm{E}+04$ & & 762 & $1.52 \mathrm{E}+04$ \\
Diesel fuel, L & $1.48 \mathrm{E}+05$ & $2.97 \mathrm{E}+06$ & & $8.21 \mathrm{E}+04$ & \\
\hline
\end{tabular}


TABLE 4.2b Resources Required during Operation of the Engineered Trench Disposal Facility, New Inventory

\begin{tabular}{lrrrrr}
\hline & \multicolumn{3}{c}{ 30-Gallon Disposal Containers } & & \multicolumn{2}{c}{ 55-Gallon Disposal Containers } \\
\cline { 2 - 3 } \multicolumn{1}{c}{ Item } & Annually & Over 25 Years & & Annually & Over 25 Years \\
\hline Water, ML & 0.084 & 2.09 & & 0.052 & 1.31 \\
Electricity, MW-h & 1,030 & $2.58 \mathrm{E}+04$ & & 765 & $1.91 \mathrm{E}+04$ \\
Diesel fuel, L & $1.49 \mathrm{E}+05$ & $3.73 \mathrm{E}+06$ & & $8.26 \mathrm{E}+04$ & $2.07 \mathrm{E}+06$ \\
\hline
\end{tabular}

TABLE 4.3a Materials and Resources Required during Construction of the Vault Disposal Facility, Original Inventory

\begin{tabular}{|c|c|c|c|c|c|}
\hline \multirow[b]{2}{*}{ Item } & \multirow{2}{*}{$\begin{array}{c}\text { Per } \\
\text { Vault }\end{array}$} & \multicolumn{2}{|c|}{$\begin{array}{l}\text { 30-Gallon Disposal } \\
\text { Containers }\end{array}$} & \multicolumn{2}{|c|}{$\begin{array}{c}\text { 55-Gallon Disposal } \\
\text { Containers }\end{array}$} \\
\hline & & Annually & Total & Annually & Total \\
\hline Number of vaults & 1 & 3.8 & 76 & 4.2 & 84 \\
\hline Concrete, redi-mix, $\mathrm{m}^{3}$ & 1,750 & 6,650 & 133,000 & 7,350 & 147,000 \\
\hline Gravel, te & 910 & 3,460 & 69,200 & 3,820 & 76,400 \\
\hline Liner, $\mathrm{m}^{2}$ & 2,220 & 8,440 & 168,700 & 9,320 & 186,500 \\
\hline Steel, te & 58.5 & 220 & 4,400 & 250 & 4,900 \\
\hline Water, ML & 0.78 & 2.96 & 59.3 & 3.28 & 65.5 \\
\hline Excavated material, $\mathrm{m}^{3}$ & 7,520 & 28,600 & 572,000 & 31,600 & 632,000 \\
\hline Electricity, kW-h & 12,500 & 47,500 & 950,000 & 52,500 & $1,050,000$ \\
\hline Diesel fuel, L & 17,800 & 67,600 & $1,353,000$ & 74,800 & $1,495,000$ \\
\hline
\end{tabular}


TABLE 4.3b Materials and Resources Required during Construction of the Vault Disposal Facility, New Inventory

\begin{tabular}{|c|c|c|c|c|c|}
\hline \multirow[b]{2}{*}{ Item } & \multirow{2}{*}{$\begin{array}{c}\text { Per } \\
\text { Vault }\end{array}$} & \multicolumn{2}{|c|}{$\begin{array}{c}\text { 30-Gallon Disposal } \\
\text { Containers }\end{array}$} & \multicolumn{2}{|c|}{$\begin{array}{c}\text { 55-Gallon Disposal } \\
\text { Containers }\end{array}$} \\
\hline & & Annually & Total & Annually & Total \\
\hline Number of vaults & 1 & 3.8 & 95 & 4.2 & 105 \\
\hline Concrete, redi-mix, $\mathrm{m}^{3}$ & 1,750 & 6,650 & $1.66 \mathrm{E}+05$ & 7,350 & $1.84 \mathrm{E}+05$ \\
\hline Gravel, te & 910 & 3,460 & $8.65 \mathrm{E}+04$ & 3,820 & $9.56 \mathrm{E}+04$ \\
\hline Liner, $\mathrm{m}^{2}$ & 2,220 & 8,440 & $2.11 \mathrm{E}+05$ & 9,320 & $2.33 \mathrm{E}+05$ \\
\hline Steel, te & 58.5 & 58.5 & 5,600 & 250 & 6,100 \\
\hline Water, ML & 0.78 & 2.96 & 74.1 & 3.28 & 81.9 \\
\hline Excavated material, $\mathrm{m}^{3}$ & 7,520 & $2.86 \mathrm{E}+04$ & $7.14 \mathrm{E}+05$ & $3.16 \mathrm{E}+04$ & $7.90 \mathrm{E}+05$ \\
\hline Electricity, kW-h & $1.25 \mathrm{E}+04$ & $4.75 \mathrm{E}+04$ & $1.19 \mathrm{E}+06$ & $5.25 \mathrm{E}+04$ & $1.31 \mathrm{E}+06$ \\
\hline Diesel fuel, L & $1.78 \mathrm{E}+04$ & $6.76 \mathrm{E}+04$ & $1.69 \mathrm{E}+06$ & $7.48 \mathrm{E}+04$ & $1.87 \mathrm{E}+06$ \\
\hline
\end{tabular}

TABLE 4.4a Resources Required during Operation of the Vault Disposal Facility, Original Inventory

\begin{tabular}{|c|c|c|c|c|c|c|}
\hline \multirow[b]{2}{*}{ Item } & \multicolumn{3}{|c|}{ 30-Gallon Disposal Containers } & \multicolumn{3}{|c|}{ 55-Gallon Disposal Containers } \\
\hline & $\begin{array}{c}\text { Per } \\
\text { Vault }\end{array}$ & Annually & Over 20 Years & $\begin{array}{c}\text { Per } \\
\text { Vault }\end{array}$ & Annually & Over 20 Years \\
\hline Number of vaults & 1 & 3.8 & 76 & 1 & 4.2 & 84 \\
\hline Water, ML & 0.02 & 0.076 & 1.52 & 0.02 & 0.084 & 1.68 \\
\hline Electricity, kW-h & 328 & 1,250 & $2.49 \mathrm{E}+04$ & 328 & 1,380 & $2.76 \mathrm{E}+04$ \\
\hline Diesel fuel, L & $5.11 \mathrm{E}+04$ & $1.94 \mathrm{E}+05$ & $3.88 \mathrm{E}+06$ & $5.11 \mathrm{E}+04$ & $2.15 \mathrm{E}+05$ & $4.29 \mathrm{E}+06$ \\
\hline
\end{tabular}

TABLE 4.4b Resources Required during Operation of the Vault Disposal Facility, New Inventory

\begin{tabular}{|c|c|c|c|c|c|c|}
\hline \multirow[b]{2}{*}{ Item } & \multicolumn{3}{|c|}{ 30-Gallon Disposal Containers } & \multicolumn{3}{|c|}{ 55-Gallon Disposal Containers } \\
\hline & $\begin{array}{c}\text { Per } \\
\text { Vault }\end{array}$ & Annually & Over 25 Years & $\begin{array}{c}\text { Per } \\
\text { Vault }\end{array}$ & Annually & Over 25 Years \\
\hline Number of vaults & 1 & 3.8 & 95 & 1 & 4.2 & 105 \\
\hline Water, ML & 0.02 & 0.076 & 1.9 & 0.02 & 0.084 & 2.1 \\
\hline Electricity, kW-h & 328 & 1,250 & $3.12 \mathrm{E}+04$ & 328 & 1,380 & $3.44 \mathrm{E}+04$ \\
\hline Diesel fuel, L & $5.11 \mathrm{E}+04$ & $1.94 \mathrm{E}+05$ & $4.85 \mathrm{E}+06$ & $5.11 \mathrm{E}+04$ & $2.15 \mathrm{E}+05$ & $5.37 \mathrm{E}+06$ \\
\hline
\end{tabular}


TABLE 4.5a Materials and Resources Required during Construction of the Mined-Cavity Facility, Original Inventory

\begin{tabular}{lrr}
\hline \multicolumn{1}{c}{ Item } & $\begin{array}{c}\text { 30-Gallon } \\
\text { Disposal Containers }\end{array}$ & $\begin{array}{c}\text { 55-Gallon } \\
\text { Disposal Containers }\end{array}$ \\
\hline Water, ML & 16.7 & 14.0 \\
Concrete, redi-mix, ${ }^{3}$ & $9.90 \mathrm{E}+04$ & $8.20 \mathrm{E}+04$ \\
Steel, te & 3,890 & 3,230 \\
Electricity, GW-h & 5,760 & 4,810 \\
Diesel fuel, L & $7.16 \mathrm{E}+05$ & $5.83 \mathrm{E}+05$ \\
Excavated material, $\mathrm{m}^{3}$ & $1.22 \mathrm{E}+06$ & $9.90 \mathrm{E}+05$ \\
\hline
\end{tabular}

TABLE 4.5b Materials and Resources Required during Construction of the Mined-Cavity Facility, New Inventory

\begin{tabular}{|c|c|c|}
\hline Item & $\begin{array}{c}\text { 30-Gallon } \\
\text { Disposal Containers }\end{array}$ & $\begin{array}{c}\text { 55-Gallon } \\
\text { Disposal Containers }\end{array}$ \\
\hline Water, ML & 19.4 & 16.1 \\
\hline Concrete, redi-mix, $\mathrm{m}^{3}$ & $1.16 \mathrm{E}+05$ & $9.50 \mathrm{E}+04$ \\
\hline Steel, te & 4,540 & 3,740 \\
\hline Electricity, GW-h & 6,670 & 5,540 \\
\hline Diesel fuel, L & $8.46 \mathrm{E}+05$ & $6.84 \mathrm{E}+05$ \\
\hline Excavated material, $\mathrm{m}^{3}$ & $1.44 \mathrm{E}+06$ & $1.16 \mathrm{E}+06$ \\
\hline
\end{tabular}

TABLE 4.6a Resources Required during Operation of the Mined-Cavity Facility, Original Inventory

\begin{tabular}{|c|c|c|c|c|}
\hline \multirow[b]{2}{*}{ Item } & \multicolumn{2}{|c|}{ 30-Gallon Disposal Containers } & \multicolumn{2}{|c|}{ 55-Gallon Disposal Containers } \\
\hline & Annually & Over 20 Years & Annually & Over 20 Years \\
\hline Water, ML & 3.09 & 61.8 & 2.33 & 46.5 \\
\hline Electricity, MW-h & 8,310 & $1.66 \mathrm{E}+05$ & 6,140 & $1.23 \mathrm{E}+05$ \\
\hline Diesel fuel, L & 9,300 & $1.86 \mathrm{E}+05$ & 6,230 & $1.25 \mathrm{E}+05$ \\
\hline
\end{tabular}


TABLE 4.6b Resources Required during Operation of the Mined-Cavity Facility, New Inventory

\begin{tabular}{lrrrrr}
\hline & \multicolumn{3}{c}{ 30-Gallon Disposal Containers } & & \multicolumn{2}{c}{ 55-Gallon Disposal Containers } \\
\cline { 2 - 3 } \multicolumn{1}{c}{ Item } & Annually & Total & & Annually & Total \\
\hline & & & & & \\
Water, ML & 3.10 & 77.5 & & 2.33 & 58.3 \\
Electricity, GW-h & 8,340 & $2.09 \mathrm{E}+05$ & & 6,160 & $1,54 \mathrm{E}+05$ \\
Diesel fuel, L & 9,350 & $2.34 \mathrm{E}+05$ & & 6,260 & $1.57 \mathrm{E}+05$ \\
\hline
\end{tabular}

TABLE 4.7a Materials and Resources Required during Construction of the Wasteform Facility, Original Inventory

\begin{tabular}{lcc}
\hline \multicolumn{1}{c}{ Item } & $\begin{array}{c}\text { 30-Gallon } \\
\text { Disposal Containers }\end{array}$ & $\begin{array}{c}\text { 55-Gallon } \\
\text { Disposal Containers }\end{array}$ \\
\hline Water, ML & & \\
Concrete, redi-mix, $\mathrm{m}^{3}$ & 3.3 & 2.7 \\
Steel, te & 5,591 & 4,286 \\
Excavated material, $\mathrm{m}^{3}$ & 349 & 271 \\
Electricity, MW-h & 9,550 & 7,550 \\
Masonry brick, m ${ }^{2}$ & 480 & 410 \\
Diesel fuel, L & 573 & 573 \\
\hline
\end{tabular}

TABLE 4.7b Materials and Resources Required during Construction of the Wasteform Facility, New Inventory

\begin{tabular}{lcc}
\hline \multicolumn{1}{c}{ Item } & $\begin{array}{c}\text { 30-Gallon } \\
\text { Disposal Containers }\end{array}$ & $\begin{array}{c}\text { 55-Gallon } \\
\text { Disposal Containers }\end{array}$ \\
\hline Water, ML & & \\
Concrete, redi-mix, $\mathrm{m}^{3}$ & 3.4 & 2.7 \\
Steel, te & 5,724 & 4,286 \\
Excavated material, $\mathrm{m}^{3}$ & 357 & 271 \\
Electricity, MW-h & 9,750 & 7,550 \\
Masonry brick, m & 487 & 410 \\
Diesel fuel, L & 573 & 573 \\
\hline
\end{tabular}


TABLE 4.8a Estimated Volume of Concrete Required for the Wasteform Facility, Original Inventory

\begin{tabular}{lcccc}
\hline & \multicolumn{4}{c}{ Concrete Required $\left(\mathrm{m}^{3}\right)$} \\
\cline { 2 - 5 } \multicolumn{1}{c}{ Structure } & Floor & Walls & Roof & Total \\
\hline $\begin{array}{l}\text { Product receiving and } \\
\text { shipping warehouse, }\end{array}$ & 2,482 & 759 & 2,068 & 5,308 \\
$\begin{array}{l}\text { 30-gal disposal containers } \\
\text { Product receiving and }\end{array}$ & 1,871 & 572 & 1,559 & 4,003 \\
$\begin{array}{l}\text { shipping warehouse, } \\
\text { 55-gal disposal containers }\end{array}$ & & & & \\
Administration building & 88 & 94 & & \\
\hline
\end{tabular}

TABLE 4.8b Estimated Volume of Concrete Required for the Wasteform Facility, New Inventory

\begin{tabular}{lcccc}
\hline & \multicolumn{4}{c}{ Concrete Required $\left(\mathrm{m}^{3}\right)$} \\
\cline { 2 - 5 } \multicolumn{1}{c}{ Structure } & Floor & Walls & Roof & Total \\
\hline $\begin{array}{l}\text { Product receiving and } \\
\text { shipping warehouse, }\end{array}$ & 2,544 & 778 & 2,120 & 5,441 \\
$\begin{array}{l}\text { 30-gal disposal containers } \\
\text { Product receiving and }\end{array}$ & 1,871 & 572 & 1,559 & 4,003 \\
$\begin{array}{l}\text { shipping warehouse, } \\
\text { 55-gal disposal containers }\end{array}$ & & & & \\
Administration building & 88 & 94 & & \\
\hline
\end{tabular}


TABLE 4.9a Resources Required during Operation of the Wasteform Facility, Original Inventory

\begin{tabular}{lccccc}
\hline & \multicolumn{2}{c}{$\begin{array}{c}\text { 30-Gallon Disposal } \\
\text { Containers }\end{array}$} & & \multicolumn{2}{c}{$\begin{array}{c}55-\text { Gallon Disposal } \\
\text { Containers }\end{array}$} \\
\cline { 2 - 3 } \cline { 5 - 6 } \multicolumn{1}{c}{ Item } & Annually & Over 20 Years & & Annually & Over 20 Years \\
\cline { 2 - 3 } & 0.62 & 12 & & 0.52 & 10 \\
Water, ML & 141 & 2,830 & & 112 & 2,240 \\
$\begin{array}{l}\text { Natural gas, therms } \\
\text { (1E+05 Btu) }\end{array}$ & & & & 579 & 11,600 \\
$\begin{array}{l}\text { Electricity, MW-h } \\
\text { Diesel fuel, L }\end{array}$ & 671 & 13,400 & & 502 & 10,000 \\
\hline
\end{tabular}

TABLE 4.9b Resources Required during Operation of the Wasteform Facility, New Inventory

\begin{tabular}{lccccc}
\hline & \multicolumn{2}{c}{$\begin{array}{c}\text { 30-Gallon Disposal } \\
\text { Containers }\end{array}$} & & & \multicolumn{2}{c}{$\begin{array}{c}\text { 55-Gallon Disposal } \\
\text { Containers }\end{array}$} \\
\cline { 2 - 3 } \cline { 5 - 6 } \cline { 5 - 6 } & Annually & Over 25 Years & & Annually & Over 25 Years \\
\hline Water, ML & 0.63 & 16 & & 0.52 & 13 \\
Natural gas, therms & 144 & 3,610 & & 112 & 2,800 \\
$\begin{array}{l}\text { (1E+05 Btu) } \\
\text { Electricity, MW-h }\end{array}$ & 680 & 17,000 & & 579 & 14,500 \\
Diesel fuel, L & 561 & 14,000 & & 502 & 12,600 \\
\hline
\end{tabular}




\section{PERSONNEL STAFFING ESTIMATES}

The preconceptual staffing estimates presented here are based on the same methodology as used in the Engineering Analysis Report. The staffing estimates are divided into construction and operational personnel requirements.

\subsection{CONSTRUCTION LABOR FORCE}

The construction labor force would be organized into at least five groups, as described below.

Management, Engineering, Design, Permitting (Home Office): This group includes management, planning, engineering through Title III, and permitting personnel. Permitting includes licensing activities and National Environmental Policy Act (NEPA) documentation. This group is typically located at the contractors' home or regional office, rather than in the field.

Management and Supervision at the Construction Site (Field Office): This group represents overall field management and supervision during actual construction and excavation. Personnel would be stationed in trailers initially. They would relocate to finished buildings (e.g., administration building) upon their completion. This group would remain at one relatively constant level for construction of the wasteform facility and another relatively constant level during construction of the disposal facility.

Site Preparation: This group includes the surveyors, operating engineers, truck drivers, and laborer who would provide the initial construction entrance, temporary (gravel) roads, storm water management, initial grubbing, installation of utility service, and associated activities. The level of effort for this group would be greatest during construction of the wasteform facility, but would continue for the first couple of years of construction of the disposal facility.

Construction: This group includes those who would be involved in building the wasteform facility and constructing the disposal facilities.

Checkout and Startup: This group includes those involved in readiness assessments, final licensing and permitting activities, and training and certification of the operating staff. 
Construction labor estimates (full-time equivalent-years [FTE-yr]) are summarized for the three disposal options in Tables $5.1 \mathrm{a}^{1}$ and $5.1 \mathrm{~b}$ for the original inventory and the new inventory, respectively. Tables $5.2 \mathrm{a}$ and $5.2 \mathrm{~b}$ provide estimates of the employment buildup by year during construction of the wasteform facility for the original inventory and the new inventory, respectively. Tables $5.3 \mathrm{a}$ and $5.3 \mathrm{~b}$ provide estimates of the employment buildup by year during construction of the mined-cavity disposal facility for the original inventory and the new inventory, respectively. For the other two disposal options, a constant number of construction employees over the 20 -year construction period can be assumed.

\subsection{OPERATIONS LABOR FORCE}

Operation labor estimates (in FTEs) are summarized in Tables 5.4a and 5.4b for the original inventory and the new inventory, respectively. These estimates are based on the operations that occur in the disposal facility and the wasteform facility that are presented in detail in Appendix B.

Product Receiving and Shipping Warehouse: The operations in the warehouse facility would include unloading and inspecting arriving pallets, transferring them to storage, transferring the pallets from storage to the shipping bay, and loading the pallets for transport to the disposal units.

Disposal Facility: Some operations would be common to all three types of disposal facilities, while other operations would be specific to one type. Common operations include transporting the drums to the disposal units and emplacing them in the disposal units. For the engineered trench and vault facilities, the area around the drums in the disposal unit must be filled with material and the trench or vault must undergo a closure operation. Although the fill and trench/vault closure operations would not apply to a mined cavity, there would be extra loading and unloading operations for the latter. To preserve the quality of the underground air in the mined cavity, an electric vehicle would be used to transport pallets underground. Therefore, pallets must be unloaded from diesel-fuel vehicles used aboveground and reloaded onto the electric vehicles used underground.

\footnotetext{
${ }^{1}$ For reader convenience, tables referred to in Section 5 are placed at the end of the section.
} 
TABLE 5.1a Summary of Construction Labor Estimates (FTE-yr), Original Inventory

\begin{tabular}{|c|c|c|c|c|c|c|}
\hline \multirow[b]{2}{*}{$\begin{array}{c}\text { Disposal } \\
\text { Approach }\end{array}$} & \multicolumn{3}{|c|}{ 30-Gallon Disposal Containers } & \multicolumn{3}{|c|}{ 55-Gallon Disposal Containers } \\
\hline & $\begin{array}{c}\text { Wasteform } \\
\text { Facility }\end{array}$ & $\begin{array}{c}\text { Disposal } \\
\text { Facility }\end{array}$ & Total & $\begin{array}{c}\text { Wasteform } \\
\text { Facility }\end{array}$ & $\begin{array}{c}\text { Disposal } \\
\text { Facility }\end{array}$ & Total \\
\hline Trenches & 283 & 430 & 713 & 204 & 420 & 624 \\
\hline Vaults & 283 & 900 & 1,183 & 204 & 960 & 1,164 \\
\hline Mined cavity & 283 & 3,800 & 4,083 & 204 & 3,400 & 3,604 \\
\hline
\end{tabular}

TABLE 5.1b Summary of Construction Labor Estimates (FTE-yr), New Inventory

\begin{tabular}{|c|c|c|c|c|c|c|}
\hline \multirow[b]{2}{*}{$\begin{array}{l}\text { Disposal } \\
\text { Approach }\end{array}$} & \multicolumn{3}{|c|}{ 30-Gallon Disposal Containers } & \multicolumn{3}{|c|}{ 55-Gallon Disposal Containers } \\
\hline & $\begin{array}{c}\text { Wasteform } \\
\text { Facility }\end{array}$ & $\begin{array}{c}\text { Disposal } \\
\text { Facility }\end{array}$ & Total & $\begin{array}{c}\text { Wasteform } \\
\text { Facility }\end{array}$ & $\begin{array}{c}\text { Disposal } \\
\text { Facility }\end{array}$ & Total \\
\hline Trenches & 292 & 450 & 742 & 204 & 430 & 34 \\
\hline Vaults & 292 & 1,030 & 1,322 & 204 & 1,090 & 1,294 \\
\hline Mined cavity & 292 & 4,300 & 4,592 & 204 & 3,700 & 3,904 \\
\hline
\end{tabular}

TABLE 5.2a Number of Construction Workers Needed by Year for the Wasteform Facility, Original Inventory

\begin{tabular}{|c|c|c|c|c|c|c|c|c|}
\hline \multirow[b]{2}{*}{ Employees } & \multicolumn{4}{|c|}{ 30-Gallon Disposal Containers } & \multicolumn{4}{|c|}{ 55-Gallon Disposal Containers } \\
\hline & Year 1 & Year 2 & Year 3 & Subtotal & Year 1 & Year 2 & Year 3 & Subtotal \\
\hline $\begin{array}{l}\text { Total craft } \\
\text { workers }\end{array}$ & 65 & 86 & 86 & 237 & 46 & 62 & 62 & 169 \\
\hline $\begin{array}{l}\text { Construction } \\
\text { management and } \\
\text { support staff }\end{array}$ & 7 & 14 & 22 & 43 & 5 & 10 & 15 & 31 \\
\hline Total & 72 & 101 & 108 & 280 & 51 & 72 & 77 & 200 \\
\hline
\end{tabular}


TABLE 5.2b Number of Construction Workers Needed by Year for the Wasteform Facility, New Inventory

\begin{tabular}{|c|c|c|c|c|c|c|c|c|}
\hline \multirow[b]{2}{*}{ Employees } & \multicolumn{4}{|c|}{ 30-Gallon Disposal Containers } & \multicolumn{4}{|c|}{ 55-Gallon Disposal Containers } \\
\hline & Year 1 & Year 2 & Year 3 & Subtotal & Year 1 & Year 2 & Year 3 & Subtotal \\
\hline $\begin{array}{l}\text { Total craft } \\
\text { workers }\end{array}$ & 67 & 89 & 89 & 245 & 46 & 62 & 62 & 169 \\
\hline $\begin{array}{l}\text { Construction } \\
\text { management and } \\
\text { support staff }\end{array}$ & 7 & 15 & 22 & 45 & 5 & 10 & 15 & 31 \\
\hline Total & 74 & 104 & 112 & 290 & 51 & 72 & 77 & 200 \\
\hline
\end{tabular}

TABLE 5.3a Number of Construction Workers Needed by Year for Mined-Cavity Disposal Facility, Original Inventory

\begin{tabular}{|c|c|c|c|c|c|c|c|c|c|}
\hline Employees & Year 1 & Year 2 & Year 3 & Year 4 & Year 5 & Year 6 & Year 7 & Year 8 & Total \\
\hline \multicolumn{10}{|l|}{ 30-Gallon Drums } \\
\hline Total craft workers & 111 & 287 & 456 & 583 & 697 & 697 & 473 & 171 & 3,474 \\
\hline $\begin{array}{l}\text { Construction } \\
\text { management and } \\
\text { Support staff }\end{array}$ & 16 & 33 & 51 & 51 & 63 & 63 & 33 & 16 & 326 \\
\hline Total & 127 & 320 & 507 & 633 & 760 & 760 & 507 & 187 & 3,800 \\
\hline \multicolumn{10}{|l|}{ 55-Gallon Drums } \\
\hline Total craft workers & 99 & 256 & 408 & 521 & 623 & 623 & 424 & 153 & 3,109 \\
\hline $\begin{array}{l}\text { Construction } \\
\text { management and } \\
\text { support staff }\end{array}$ & 14 & 30 & 45 & 45 & 57 & 57 & 30 & 14 & 291 \\
\hline Total & 113 & 286 & 453 & 567 & 680 & 680 & 453 & 167 & 3,400 \\
\hline
\end{tabular}


TABLE 5.3b Number of Construction Workers Needed by Year for Mined-Cavity Disposal Facility, New Inventory

\begin{tabular}{|c|c|c|c|c|c|c|c|c|c|}
\hline Employees & Year 1 & Year 2 & Year 3 & Year 4 & Year 5 & Year 6 & Year 7 & Year 8 & Total \\
\hline \multicolumn{10}{|l|}{ 30-Gallon Drums } \\
\hline Total craft workers & 126 & 324 & 516 & 659 & 788 & 788 & 536 & 194 & 3,931 \\
\hline $\begin{array}{l}\text { Construction } \\
\text { management and } \\
\text { support staff }\end{array}$ & 18 & 38 & 58 & 58 & 72 & 72 & 38 & 18 & 369 \\
\hline Total & 143 & 362 & 573 & 717 & 860 & 860 & 573 & 212 & 4,300 \\
\hline \multicolumn{10}{|l|}{ 55-Gallon Drums } \\
\hline Total craft workers & 108 & 279 & 444 & 567 & 678 & 678 & 461 & 167 & 3,383 \\
\hline $\begin{array}{l}\text { Construction } \\
\text { management and } \\
\text { support staff }\end{array}$ & 15 & 32 & 49 & 49 & 62 & 62 & 32 & 15 & 317 \\
\hline Total & 123 & 311 & 493 & 617 & 740 & 740 & 493 & 182 & 3,700 \\
\hline
\end{tabular}

TABLE 5.4a Summary of Operational Labor Estimates (FTEs), Original Inventory

\begin{tabular}{lcccccccc}
\hline & \multicolumn{3}{c}{ 30-Gallon Disposal Containers } & & \multicolumn{3}{c}{ 55-Gallon Disposal Containers } \\
\cline { 2 - 3 } $\begin{array}{c}\text { Disposal } \\
\text { Approach }\end{array}$ & $\begin{array}{c}\text { Wasteform } \\
\text { Facility }\end{array}$ & $\begin{array}{c}\text { Disposal } \\
\text { Facility }\end{array}$ & Total & & $\begin{array}{c}\text { Wasteform } \\
\text { Facility }\end{array}$ & $\begin{array}{c}\text { Disposal } \\
\text { Facility }\end{array}$ & Total \\
\hline \multirow{2}{*}{ Trenches } & 40 & 22 & 62 & & 34 & 17 & 52 \\
Vaults & 40 & 47 & 86 & & 34 & 36 & 71 \\
Mined cavity & 41 & 30 & 71 & & 35 & 25 & 61 \\
\hline
\end{tabular}


TABLE 5.4b Summary of Operational Labor Estimates (FTEs), New Inventory

\begin{tabular}{lcccccccc}
\hline & \multicolumn{3}{c}{ 30-Gallon Disposal Containers } & & \multicolumn{3}{c}{ 55-Gallon Disposal Containers } \\
\cline { 2 - 3 } $\begin{array}{c}\text { Disposal } \\
\text { Approach }\end{array}$ & $\begin{array}{c}\text { Wasteform } \\
\text { Facility }\end{array}$ & $\begin{array}{c}\text { Disposal } \\
\text { Facility }\end{array}$ & Total & & $\begin{array}{c}\text { Wasteform } \\
\text { Facility }\end{array}$ & $\begin{array}{c}\text { Disposal } \\
\text { Facility }\end{array}$ & Total \\
\hline \multirow{2}{*}{ Trenches } & 40 & 22 & 62 & & 35 & 17 & 2 \\
Vaults & 40 & 47 & 86 & & 35 & 36 & 71 \\
Mined cavity & 41 & 30 & 71 & & 36 & 25 & 61 \\
\hline
\end{tabular}




\section{FACILITY EMISSIONS AND WASTES}

\subsection{ESTIMATES OF EMISSIONS AND WASTES GENERATED DURING CONSTRUCTION}

Wastes generated during construction of the disposal facility would be typical of large construction projects. Wastes would be primarily construction debris, including concrete fragments, and sanitary wastes of the labor force. Emissions would result primarily from the use of fuels in construction, removing construction debris, and disturbing the land (dust). To be consistent with the Engineering Analysis Report, the amount of concrete waste was estimated on the basis of the assumption that $2 \%$ of the concrete usage would be spoilage. The other solid wastes, which would include construction debris and rock cuttings, were taken to be eight times the volume of the concrete spoilage. Steel waste was taken to be $0.5 \%$ of the steel requirements. These solid nonhazardous wastes would be to be disposed of in a municipal solid waste landfill. The amount of sanitary waste was estimated on the basis of total construction workforce. Liquid (sanitary) nonhazardous wastes would either be treated in a portable system or hauled to off-site facilities for treatment and disposal.

Estimates of criteria pollutant emissions generated during construction were based on the estimated amounts of fuel used by the trucks and cranes during construction. Standard U.S. Environmental Protection Agency (EPA) emission factors were used in these calculations (EPA 1993). Emissions were calculated from the total quantity of liquid fuel consumed (gasoline and diesel). Dust was estimated from the amount of disturbed land area and the duration that the disturbed area would be under construction.

National Ambient Air Quality Standards (NAAQS) for criteria air pollutants are given in Table 6.1. ${ }^{1}$ Estimates of construction wastes and emissions are given in Table 6.2 for the engineered trench disposal facility, in Table 6.3 for the vault disposal facility, in Table 6.4 for the mined-cavity disposal facility, and in Table 6.5 for the wasteform facility. The construction period was taken as 20 years for the engineered trench and vault disposal facilities for the original inventory and 25 years for the new inventory, 7.5 years for the mined-cavity disposal facility for both inventories, and 3 years for the wasteform facility for both inventories. Emissions of the following criteria air pollutants were estimated: sulfur dioxide $\left(\mathrm{SO}_{2}\right)$, nitrogen oxides $\left(\mathrm{NO}_{\mathrm{x}}\right)$, nonmethane hydrocarbons (NMHCs), carbon monoxide $(\mathrm{CO})$, methane $\left(\mathrm{CH}_{4}\right)$, and particulate matter with a diameter of less than or equal to 10 micrometers $\left(\mathrm{PM}_{10}\right)$.

\footnotetext{
${ }^{1}$ For reader convenience, tables referred to in Section 6 are placed at the end of the section.
} 


\subsection{ESTIMATES OF EMISSIONS AND WASTES GENERATED DURING OPERATIONS}

Operation of the disposal facility would involve the receipt, inspection, and repackaging (if damaged) of drums containing depleted $\mathrm{UF}_{4}$ at the wasteform facility, transfer of these drums to the disposal units, and emplacement in the disposal units. The major wastes and emissions generated during operation would be sanitary wastes of the on-site labor force and criteria pollutant emissions from transportation of the drums and from facility space heating. Emissions of criteria pollutants were calculated on the basis of the amount of diesel fuel, gasoline, and natural gas used each year. Under normal conditions (nonaccident) of operation, radioactive waste would be generated in the wasteform facility from spent high-efficiency particulate air (HEPA) filters, damaged drums, contaminated protective clothing, and similar sources. A very small amount of liquid low-level mixed waste (LLMW) would be generated in the wasteform facility from wiping of drums (with a dilute acid and detergent wash) that do not pass visual inspection. Small amounts of nonhazardous waste (e.g., domestic and office trash) and recyclable waste (e.g., paper, aluminum) would also be generated in the wasteform facility.

Annual emissions from operations of the disposal facilities are presented in Tables 6.6a and $6.6 \mathrm{~b}$ for the original inventory and new inventory, respectively. Annual emissions and wastes from operations of the wasteform facility are found in Tables $6.7 \mathrm{a}$ and $6.7 \mathrm{~b}$ for the original inventory and the new inventory, respectively, in a form consistent with the Engineering Analysis Report. 
TABLE 6.1 National Ambient Air Quality Standards (NAAQS) for Criteria Air Pollutants

\begin{tabular}{ccc}
\hline $\begin{array}{c}\text { Criteria Air } \\
\text { Pollutant }\end{array}$ & Averaging Time & Primary Standard \\
\hline $\mathrm{CO}$ & 1 hour & $40 \mathrm{mg} / \mathrm{m}^{3}$ \\
& 8 hours & $10 \mathrm{mg} / \mathrm{m}^{3}$ \\
& 3 hours & $160 \mu \mathrm{g} / \mathrm{m}^{3}$ \\
Hydrocarbons & Annual & $100 \mu \mathrm{g} / \mathrm{m}^{3}$ \\
$\mathrm{NO}_{\mathrm{x}}\left(\right.$ as $\left.\mathrm{NO}_{2}\right)$ & & $365 \mu \mathrm{g} / \mathrm{m}^{3}$ \\
$\mathrm{SO}_{\mathrm{x}}\left(\right.$ as $\left.\mathrm{SO}_{2}\right)$ & 24-hours & \\
& Annual & $80 \mu \mathrm{g} / \mathrm{m}^{3}$ \\
& & $150 \mu \mathrm{g} / \mathrm{m}^{3}$ \\
$\mathrm{PM}_{10}$ & 24-hours & \\
& Annual & $50 \mu \mathrm{g} / \mathrm{m}^{3}$ \\
\hline
\end{tabular}

a Not to be exceeded more than once a year.

Source: 40 CFR 50.0 et seq.

TABLE 6.2 Estimated Emissions and Wastes from Construction of Trench Disposal Facility

\begin{tabular}{|c|c|c|c|c|c|}
\hline \multirow[b]{2}{*}{ Material } & \multirow[b]{2}{*}{ Units } & \multicolumn{2}{|c|}{ Original Inventory } & \multicolumn{2}{|c|}{ New Inventory } \\
\hline & & $\begin{array}{l}\text { 30-Gallon } \\
\text { Drums }\end{array}$ & $\begin{array}{l}\text { 55-Gallon } \\
\text { Drums }\end{array}$ & $\begin{array}{l}\text { 30-Gallon } \\
\text { Drums }\end{array}$ & $\begin{array}{l}\text { 55-Gallon } \\
\text { Drums }\end{array}$ \\
\hline \multicolumn{6}{|l|}{ Emissions (per year) } \\
\hline $\mathrm{CO}$ & te & 2.35 & 1.30 & 2.36 & 1.31 \\
\hline NMHC & te & 0.82 & 0.46 & 0.83 & 0.46 \\
\hline $\mathrm{NO}_{\mathrm{x}}$ & te & 10.9 & 6.02 & 11.0 & 6.06 \\
\hline $\mathrm{SO}_{2}$ & te & 0.72 & 0.40 & 0.72 & 0.40 \\
\hline $\mathrm{PM}_{10}$ & te & 51 & 43 & 63 & 53 \\
\hline Methane & te & $6.74 \mathrm{E}-02$ & $3.73 \mathrm{E}-02$ & $6.79 \mathrm{E}-02$ & $3.75 \mathrm{E}-02$ \\
\hline \multicolumn{6}{|l|}{ Wastes (total) } \\
\hline Hazardous solids & $\mathrm{m}^{3}$ & 23 & 22 & 24 & 23 \\
\hline Hazardous liquids & $\mathrm{m}^{3}$ & 46 & 45 & 48 & 46 \\
\hline Sanitary liquids & $\mathrm{m}^{3}$ & $6.60 \mathrm{E}+03$ & $6.40 \mathrm{E}+03$ & $6.90 \mathrm{E}+03$ & $6.60 \mathrm{E}+03$ \\
\hline Other liquids & $\mathrm{m}^{3}$ & $2.90 \mathrm{E}+03$ & $2.90 \mathrm{E}+03$ & $3.10 \mathrm{E}+03$ & $2.90 \mathrm{E}+03$ \\
\hline
\end{tabular}


TABLE 6.3 Estimated Emissions and Wastes from Construction of Vault Disposal Facility

\begin{tabular}{|c|c|c|c|c|c|}
\hline \multirow[b]{2}{*}{ Material } & \multirow[b]{2}{*}{ Units } & \multicolumn{2}{|c|}{ Original Inventory } & \multicolumn{2}{|c|}{ New Inventory } \\
\hline & & $\begin{array}{c}\text { 30-Gallon } \\
\text { Drums }\end{array}$ & $\begin{array}{c}\text { 55-Gallon } \\
\text { Drums }\end{array}$ & $\begin{array}{c}\text { 30-Gallon } \\
\text { Drums }\end{array}$ & $\begin{array}{c}\text { 55-Gallon } \\
\text { Drums }\end{array}$ \\
\hline \multicolumn{6}{|l|}{ Emissions (per year) } \\
\hline $\mathrm{CO}$ & te & 1.07 & 1.18 & 1.07 & 1.18 \\
\hline NMHC & te & 0.38 & 0.42 & 0.38 & 0.42 \\
\hline $\mathrm{NO}_{\mathrm{x}}$ & te & 4.96 & 5.49 & 4.96 & 5.49 \\
\hline $\mathrm{SO}_{2}$ & te & 0.33 & 0.36 & 0.33 & 0.36 \\
\hline $\mathrm{PM}_{10}$ & te & 69 & 85 & 85 & 102 \\
\hline Methane & te & $3.07 \mathrm{E}-02$ & 3.40E-02 & $3.07 \mathrm{E}-02$ & $3.40 \mathrm{E}-02$ \\
\hline \multicolumn{6}{|l|}{ Wastes (total) } \\
\hline Hazardous solids & $\mathrm{m}^{3}$ & 47 & 51 & 54 & 58 \\
\hline Hazardous liquids & $\mathrm{m}^{3}$ & 96 & 102 & 110 & 116 \\
\hline Concrete & $\mathrm{m}^{3}$ & $2.66 \mathrm{E}+03$ & $2.94 \mathrm{E}+03$ & $3.33 \mathrm{E}+03$ & $3.68 \mathrm{E}+03$ \\
\hline Steel & te & 22.0 & 24.5 & 28.0 & 30.5 \\
\hline Other solid waste & $\mathrm{m}^{3}$ & $2.10 \mathrm{E}+04$ & $2.40 \mathrm{E}+04$ & $2.70 \mathrm{E}+04$ & $2.90 \mathrm{E}+04$ \\
\hline Sanitary liquids & $\mathrm{m}^{3}$ & $1.40 \mathrm{E}+04$ & $1.50 \mathrm{E}+04$ & $1.60 \mathrm{E}+04$ & $1.70 \mathrm{E}+04$ \\
\hline Other liquids & $\mathrm{m}^{3}$ & $6.10 \mathrm{E}+03$ & $6.50 \mathrm{E}+03$ & $7.03 \mathrm{E}+03$ & $7.4 \mathrm{E}+03$ \\
\hline
\end{tabular}

TABLE 6.4 Estimated Emissions and Wastes from Construction of Mined-Cavity Disposal Facility

\begin{tabular}{|c|c|c|c|c|c|}
\hline \multirow[b]{2}{*}{ Material } & \multirow[b]{2}{*}{ Units } & \multicolumn{2}{|c|}{ Original Inventory } & \multicolumn{2}{|c|}{ New Inventory } \\
\hline & & $\begin{array}{c}\text { 30-Gallon } \\
\text { Drums }\end{array}$ & $\begin{array}{c}\text { 55-Gallon } \\
\text { Drums }\end{array}$ & $\begin{array}{c}\text { 30-Gallon } \\
\text { Drums }\end{array}$ & $\begin{array}{c}\text { 55-Gallon } \\
\text { Drums }\end{array}$ \\
\hline \multicolumn{6}{|l|}{ Emissions (per year) } \\
\hline $\mathrm{CO}$ & te & 1.51 & 1.23 & 1.78 & 1.44 \\
\hline NMHC & te & 0.53 & 0.43 & 0.63 & 0.51 \\
\hline $\mathrm{NO}_{\mathrm{x}}$ & te & 7.00 & 5.70 & 8.28 & 6.69 \\
\hline $\mathrm{SO}_{2}$ & te & 0.46 & 0.38 & 0.55 & 0.44 \\
\hline $\mathrm{PM}_{10}$ & te & 636 & 452 & 837 & 593 \\
\hline Methane & te & 4.34E-02 & $3.53 \mathrm{E}-02$ & 3.07E-02. & 4.15E-02 \\
\hline \multicolumn{6}{|l|}{ Wastes (total) } \\
\hline Hazardous solids & $\mathrm{m}^{3}$ & 200 & 179 & 227 & 195 \\
\hline Hazardous liquids & $\mathrm{m}^{3}$ & 406 & 363 & 459 & 395 \\
\hline Concrete & $\mathrm{m}^{3}$ & $1.98 \mathrm{E}+03$ & $1.64 \mathrm{E}+03$ & $2.3 \mathrm{E}+03$ & $1.90 \mathrm{E}+03$ \\
\hline Steel & $\mathrm{m}^{3}$ & 19.5 & 16.2 & 22.7 & 18.7 \\
\hline Other solid waste & $\mathrm{m}^{3}$ & $1.60 \mathrm{E}+04$ & $1.30 \mathrm{E}+04$ & $1.90 \mathrm{E}+04$ & $1.50 \mathrm{E}+04$ \\
\hline Sanitary liquids & $\mathrm{m}^{3}$ & $5.80 \mathrm{E}+04$ & $5.20 \mathrm{E}+04$ & $6.60 \mathrm{E}+04$ & $5.70 \mathrm{E}+04$ \\
\hline Other liquids & $\mathrm{m}^{3}$ & $2.60 \mathrm{E}+04$ & $2.30 \mathrm{E}+04$ & $2.90 \mathrm{E}+04$ & $2.50 \mathrm{E}+04$ \\
\hline
\end{tabular}


TABLE 6.5 Estimated Emissions and Wastes from Construction of Wasteform Facility

\begin{tabular}{|c|c|c|c|c|c|}
\hline \multirow[b]{2}{*}{ Material } & \multirow[b]{2}{*}{ Units } & \multicolumn{2}{|c|}{ Original Inventory } & \multicolumn{2}{|c|}{ New Inventory } \\
\hline & & $\begin{array}{c}\text { 30-Gallon } \\
\text { Drums }\end{array}$ & $\begin{array}{l}\text { 55-Gallon } \\
\text { Drums }\end{array}$ & $\begin{array}{c}\text { 30-Gallon } \\
\text { Drums }\end{array}$ & $\begin{array}{l}\text { 55-Gallon } \\
\text { Drums }\end{array}$ \\
\hline \multicolumn{6}{|l|}{ Emissions (per year) } \\
\hline $\mathrm{CO}$ & te & 0.712 & 0.554 & 0.728 & 0.554 \\
\hline NMHC & te & 0.250 & 0.194 & 0.256 & 0.194 \\
\hline $\mathrm{NO}_{\mathrm{x}}$ & te & 3.30 & 2.57 & 3.37 & 2.57 \\
\hline $\mathrm{SO}_{2}$ & te & 0.218 & 0.169 & 0.222 & 0.169 \\
\hline $\mathrm{PM}_{10}$ & te & 17.9 & 14.6 & 18.2 & 14.6 \\
\hline Methane & te & $2.05 \mathrm{E}-02$ & 1.59E-02 & 2.09E-02 & $1.59 \mathrm{E}-02$ \\
\hline \multicolumn{6}{|l|}{ Wastes (total) } \\
\hline Hazardous solids & $\mathrm{m}^{3}$ & 14.8 & 10.6 & 15.3 & 10.6 \\
\hline Hazardous liquids & $\mathrm{m}^{3}$ & 29.9 & 21.3 & 30.9 & 21.3 \\
\hline Concrete & $\mathrm{m}^{3}$ & 110 & 90 & 110 & 90 \\
\hline Steel & te & 1.7 & 1.4 & 1.8 & 1.4 \\
\hline Other solid waste & $\mathrm{m}^{3}$ & 890 & 690 & 920 & 690 \\
\hline Sanitary liquids & $\mathrm{m}^{3}$ & $4.30 \mathrm{E}+03$ & $3.10 \mathrm{E}+03$ & $4.40 \mathrm{E}+03$ & $3.10 \mathrm{E}+03$ \\
\hline Other liquids & $\mathrm{m}^{3}$ & $1.90 \mathrm{E}+03$ & $1.40 \mathrm{E}+03$ & $2.00 \mathrm{E}+03$ & $1.40 \mathrm{E}+03$ \\
\hline
\end{tabular}

TABLE 6.6a Estimated Average Annual Emissions (in te/yr) from Operation of Disposal Facilities, Original Inventory

\begin{tabular}{|c|c|c|c|c|c|c|}
\hline \multirow[b]{2}{*}{ Emission } & \multicolumn{3}{|c|}{ 30-Gallon Drums } & \multicolumn{3}{|c|}{ 55-Gallon Drums } \\
\hline & Trench & Vault & Mine & Trench & Vault & Mine \\
\hline $\mathrm{SO}_{2}$ & 0.71 & 0.93 & $4.5 \mathrm{E}-02$ & 0.39 & 1.0 & $3.0 \mathrm{E}-02$ \\
\hline $\mathrm{NO}_{\mathrm{x}}$ & 11 & 14 & 0.68 & 6.0 & 16 & 0.46 \\
\hline Hydrocarbons & 0.89 & 1.2 & $5.6 \mathrm{E}-02$ & 0.49 & 1.3 & 3.7E-02 \\
\hline $\mathrm{CO}$ & 2.3 & 3.0 & 0.15 & 1.3 & 3.4 & $9.7 \mathrm{E}-02$ \\
\hline $\mathrm{PM}_{10}$ & 0.77 & 1.0 & $4.8 \mathrm{E}-02$ & 0.42 & 1.1 & $3.2 \mathrm{E}-02$ \\
\hline
\end{tabular}


TABLE 6.6b Estimated Average Annual Emissions (in te/yr) from Operation of Disposal Facilities, New Inventory

\begin{tabular}{|c|c|c|c|c|c|c|}
\hline \multirow[b]{2}{*}{ Emission } & \multicolumn{3}{|c|}{ 30-Gallon Drums } & \multicolumn{3}{|c|}{ 55-Gallon Drums } \\
\hline & Trench & Vault & Mine & Trench & Vault & Mine \\
\hline $\mathrm{SO}_{2}$ & 0.72 & 0.93 & $4.5 \mathrm{E}-02$ & 0.40 & 1.0 & $3.0 \mathrm{E}-02$ \\
\hline $\mathrm{NO}_{\mathrm{x}}$ & 11 & 14 & 0.68 & 6.1 & 16 & 0.46 \\
\hline Hydrocarbons & 0.90 & 1.2 & $5.6 \mathrm{E}-02$ & 0.50 & 1.3 & $3.8 \mathrm{E}-02$ \\
\hline $\mathrm{CO}$ & 2.3 & 3.0 & 0.15 & 1.3 & 3.4 & $9.8 \mathrm{E}-02$ \\
\hline $\mathrm{PM}_{10}$ & 0.77 & 1.0 & $4.8 \mathrm{E}-02$ & 0.43 & 1.1 & $3.2 \mathrm{E}-02$ \\
\hline
\end{tabular}

TABLE 6.7a Estimated Annual Emissions and Wastes from Operation of the Wasteform Facility, Original Inventory

\begin{tabular}{|c|c|c|c|c|}
\hline Material & Units & Treatability Category & 30-Gallon Drums & 55-Gallon Drums \\
\hline \multicolumn{5}{|l|}{ Emissions (per year) } \\
\hline $\mathrm{SO}_{2}$ & te & $\mathrm{NA}^{\mathrm{a}}$ & 2.7E-03 & $2.4 \mathrm{E}-03$ \\
\hline $\mathrm{NO}_{\mathrm{x}}$ & te & NA & 4.1E-02 & 3.7E-02 \\
\hline Hydrocarbons & te & NA & $3.3 \mathrm{E}-03$ & $3.0 \mathrm{E}-03$ \\
\hline Carbon monoxide & te & NA & 8.9E-03 & $8.0 \mathrm{E}-03$ \\
\hline $\mathrm{PM}_{10}$ & te & NA & $2.9 \mathrm{E}-03$ & $2.6 \mathrm{E}-03$ \\
\hline \multicolumn{5}{|l|}{ Wastes } \\
\hline Spent HEPA filters & $\mathrm{m}^{3}($ total $)$ & $\begin{array}{l}\text { Noncombustible } \\
\text { compactable LLW }\end{array}$ & 23.8 & 23.8 \\
\hline Damaged drums & $\mathrm{m}^{3}($ total $)$ & $\begin{array}{c}\text { Surface-contaminated } \\
\text { metal LLW }\end{array}$ & 7.8 & 7.8 \\
\hline Other LLW & $\mathrm{m}^{3} / \mathrm{yr}$ & Combustible solid LLW & 47.6 & 26.2 \\
\hline Inorganic solutions & $\mathrm{m}^{3} / \mathrm{yr}$ & Liquid LLMW & 0.26 & 0.18 \\
\hline $\begin{array}{l}\text { Nonhazardous } \\
\text { (sanitary) wastes }\end{array}$ & $\mathrm{m}^{3} / \mathrm{yr}$ & NA & 986 & 859 \\
\hline $\begin{array}{l}\text { Nonhazardous } \\
\text { (other) wastes }\end{array}$ & $\mathrm{m}^{3} / \mathrm{yr}$ & NA & 78 & 68 \\
\hline Recyclable wastes & $\mathrm{m}^{3} / \mathrm{yr}$ & NA & 31 & 27 \\
\hline
\end{tabular}

a $\mathrm{NA}=$ not applicable. 
TABLE 6.7b Estimated Annual Emissions and Wastes from Operation of the Wasteform Facility, New Inventory

\begin{tabular}{|c|c|c|c|c|}
\hline Material & Units & Treatability Category & 30-Gallon Drums & 55-Gallon Drums \\
\hline \multicolumn{5}{|l|}{ Emissions (per year) } \\
\hline $\mathrm{SO}_{2}$ & te & $\mathrm{NA}^{\mathrm{a}}$ & 2.7E-03 & $2.4 \mathrm{E}-03$ \\
\hline $\mathrm{NO}_{\mathrm{x}}$ & te & NA & 4.2E-02 & 3.7E-02 \\
\hline Hydrocarbons & te & NA & $3.4 \mathrm{E}-03$ & $3.0 \mathrm{E}-03$ \\
\hline Carbon monoxide & te & NA & $9.0 \mathrm{E}-03$ & $8.0 \mathrm{E}-03$ \\
\hline $\mathrm{PM}_{10}$ & te & NA & 2.9E-03 & 2.6E-03 \\
\hline \multicolumn{5}{|l|}{ Wastes } \\
\hline Spent HEPA filters & $\mathrm{m}^{3}($ total $)$ & $\begin{array}{l}\text { Noncombustible } \\
\text { compactable LLW }\end{array}$ & 23.8 & 23.8 \\
\hline Damaged drums & $\mathrm{m}^{3}($ total $)$ & $\begin{array}{c}\text { Surface-contaminated } \\
\text { metal LLW }\end{array}$ & 7.9 & 7.9 \\
\hline Other LLW & $\mathrm{m}^{3} / \mathrm{yr}$ & $\begin{array}{c}\text { Combustible solid } \\
\text { LLW }\end{array}$ & 47.9 & 26.5 \\
\hline Inorganic solutions & $\mathrm{m}^{3} / \mathrm{yr}$ & Liquid LLMW & 0.26 & 0.18 \\
\hline $\begin{array}{l}\text { Nonhazardous } \\
\text { (sanitary) wastes }\end{array}$ & $\mathrm{m}^{3} / \mathrm{yr}$ & NA & 988 & 860 \\
\hline $\begin{array}{l}\text { Nonhazardous } \\
\text { (other) wastes }\end{array}$ & $\mathrm{m}^{3} / \mathrm{yr}$ & NA & 78 & 68 \\
\hline Recyclable wastes & $\mathrm{m}^{3 /} / \mathrm{yr}$ & NA & 31 & 27 \\
\hline
\end{tabular}

a $\mathrm{NA}=$ not applicable. 


\section{DESCRIPTION OF POTENTIAL ACCIDENTS}

Accidents that could occur at the disposal and wasteform facilities are analyzed in this section. Accidents could be initiated during facility operations or could be caused by external events, including natural phenomena (earthquake and wind). Reasonably foreseeable accidents have been screened to identify the accidents that would have the greatest consequences to workers and the public. These are the "bounding" accidents that provide an envelope for the consequences of the other potential accidents that would have less impact on workers and the public. Because uranium is both radioactive and chemically toxic, the bounding accidents all involve the release of uranium. The uranium would be released in the form of $\mathrm{UF}_{4}$, except for a potential fire or explosion accident, in which uranium might be released in the form of $\mathrm{UO}_{2}$.

Four types of events were considered credible: a handling accident, a fire or explosion, an earthquake, and a tornado. Table $7.1^{1}$ summarizes the results of the accident analysis, giving the accident scenario, a description of the accident, the frequency range, and information about the source term.

A flood was not considered to be credible because it is assumed that the facility would be sited to preclude severe flooding. It is assumed that the location and design of the disposal facilities would bring the frequency below $1 \times 10^{-6} / \mathrm{yr}$. For example, NRC's regulations in 10 CFR 61.50 and 61.51 require, inter alia, that waste disposal shall not take place in a 100-year floodplain and that covers must be designed to minimize water infiltration and to direct surface water drainage away from the disposed waste.

In analyzing the potential consequences of postulated accidents, the source term, which is the amount of radioactive material released, is evaluated. The source term is the product of four factors: the material at risk (MAR); the damage fraction (DF); the respirable airborne release fraction (RARF); and the fraction of respirable airborne material released to the environment, or leak path factor (LPF).

\subsection{HANDLING ACCIDENT}

Mechanical upsets are events such as spills, forklift punctures, loss of filtration, and piping failures. In general, mechanical upset-initiated accidents would result in small releases to the atmosphere. For this analysis, the assumption is made that a forklift damages a drum and causes the drum's entire contents to be spilled. Two cases are considered. In one case, the spill occurs within the product receiving and shipping warehouse; in the other case, the spill occurs outside the warehouse. The MAR is the total radioactive material, $\mathrm{UF}_{4}$, in one drum $(364 \mathrm{~kg}$ [802 lb] for a 30 -gallon drum, $667 \mathrm{~kg}[1,407 \mathrm{lb}]$ for a 55 -gallon drum). It is assumed that the

\footnotetext{
${ }^{1}$ For reader convenience, Table 7.1 is placed at the end of the section.
} 
damage fraction is one-half, that is, half of the $\mathrm{UF}_{4}$ becomes airborne, and that the fraction of the released material in the respirable range (RARF) is $2 \times 10^{-4}$. As in the Engineering Analysis Report, it is assumed that for the indoors accident, the $\mathrm{UF}_{4}$ release would be filtered as it passed through HEPA filters with an efficiency of $99.9 \%$ (LPF $=0.001$ ) as a puff. (The accident scenario would not result in failure of off-gas filters because of the absence of energetic processes.) The source term for the accident when it occurs inside the product receiving and shipping warehouse is then $3.64 \times 10^{-5} \mathrm{~kg}\left(8.02 \times 10^{-5} \mathrm{lb}\right)$ for damage of a 30 -gallon drum and $6.7 \times 10^{-5} \mathrm{~kg}\left(1.5 \times 10^{-4} \mathrm{lb}\right)$ for a 55 -gallon drum. If the accident occurred outside the warehouse, the leak path factor would be unity, and consequently the release amount would 1,000 times greater.

The frequency of this accident per year is the product of the number of drums received per year, the number of operations per pallet, and the probability that a mishandling accident would cause damage to a drum resulting in release of radioactive material per operation. It is assumed that the mishandling accident probability $\left(1.1 \times 10^{-5}\right)$ and two handling operations per drum are the same as for mishandling of drums in the Engineering Analysis Report. For disposal in 30-gallon drums $(68,650$ drums would be handled per year), the frequency of this accident would be 1.5/yr. For disposal in 55-gallon drums (37,450 drums would be handled per year), the frequency of this accident would be $0.8 / \mathrm{yr}$. This accident is considered to be anticipated because it has a frequency greater than $0.01 / \mathrm{yr}$.

\subsection{FIRE OR EXPLOSION}

For this analysis, it is assumed that there is a fire or explosion within the product receiving and shipping warehouse that affects the contents of four drums on a pallet. The absence of combustible materials or a fire source within the warehouse building would limit the material at risk to a single pallet. This accident scenario assumes that the fire is initiated by a fuel leak from the forklift, which could be ignited by a number of sources.

The fire or explosion would cause $\mathrm{UF}_{4}$ to react with water in the atmosphere to form $\mathrm{UO}_{2}$ and HF. The entire contents of four drums would be affected (DF =1). All of the HF is assumed to be airborne and respirable $(\mathrm{RARF}=1)$. Only $0.1 \%$ of the $\mathrm{UO}_{2}$ is assumed to be airborne and respirable $(\mathrm{RARF}=0.001)$. The $\mathrm{LPF}$ for $\mathrm{UO}_{2}$ as for $\mathrm{UF}_{4}$ is taken as 0.001 . It is assumed that the warehouse has a calcium carbonate trap with a 95\% efficiency ( $\mathrm{LPF}=0.05$ ) for HF. The release is assumed to have a 30-minute duration. For 30-gallon drums with a material at risk of $1,455 \mathrm{~kg}$ $(3,208 \mathrm{lb})$, the source term would be $1.3 \mathrm{~g}(0.05 \mathrm{oz})$ of $\mathrm{UO}_{2}$ and $19 \mathrm{~kg}(42 \mathrm{lb})$ of $\mathrm{HF}$. For 55 -gallon drums with a material at risk of $2,668 \mathrm{~kg}$, the source term would be $2.3 \mathrm{~g}(0.08 \mathrm{oz})$ of $\mathrm{UO}_{2}$ and $34 \mathrm{~kg}(75 \mathrm{lb})$ of HF. The frequency of this accident $\left(9.6 \times 10^{-6} / \mathrm{yr}\right)$ is the same as was used for the fire or explosion accident in the wasteform facility in the Engineering Analysis Report. This accident is considered to extremely unlikely because its frequency is greater than $1 \times 10^{-6} / \mathrm{yr}$ and less than $1 \times 10^{-4} / \mathrm{yr}$. 


\subsection{EARTHQUAKE}

For this analysis, the product receiving and shipping warehouse is assumed to be damaged during a design basis earthquake. Review of the on-site structures indicated that this building had the greatest potential for a significant airborne release because of the potential for the overhead crane to fall during the earthquake and crush drums located beneath it, with subsequent atmospheric release of the $\mathrm{UF}_{4}$.

The material at risk would be the entire amount of depleted $\mathrm{UF}_{4}$ in storage at the product receiving and shipping warehouse, that is, the material received during a three-month period. Because the amount of $\mathrm{UF}_{4}$ received at the facility would be independent of drum size, the release would not depend on drum size. Therefore, the material at risk would be $6.24 \times 10^{6} \mathrm{~kg}$ $\left(1.38 \times 10^{7} \mathrm{lb}\right)$. The damage fraction is taken as $10 \%$. The RARF would be the same as for the handling accident (Section 7.1). The seismic event is assumed to cause failure of the building structure and its confinement system so that $100 \%$ of the $\mathrm{UF}_{4}$ released from the drums would be released from the building (LPF $=1)$, resulting in ground-level unfiltered release of $125 \mathrm{~kg}$ $(276 \mathrm{lb})$ of $\mathrm{UF}_{4}$. The release is assumed to continue for a 30-minute period. The frequency of this event $\left(5 \times 10^{-4} / \mathrm{yr}\right)$, as well as the LPF (1), DF, and release duration, are assumed to be the same as for the earthquake event analyzed in the Engineering Analysis Report. DOE hazard category 2 buildings are constructed such that earthquakes (tornadoes as well) could cause failure of the building structure and confinement at this annual frequency.

Although it might appear intuitively that the potential consequences of an earthquake on an underground facility would be more severe than on a surface facility, that does not appear to be the case. Available data on the effects of earthquakes in underground mines and tunnels indicate that they are significantly less susceptible to damage from earthquakes than are surface facilities (DOE 1980). Investigations measuring earthquake acceleration underground and the surface indicated that underground motion was four to six times less than at the surface. A study of the Alaskan earthquake of 1964 by the U.S. Geological Survey reported no significant damage to underground facilities, such as mines and tunnels, although some rocks were shaken loose in places. Therefore, it is expected that damage to mined cavities would be much less than for aboveground facilities, such as the product receiving and shipping warehouse.

\subsection{TORNADO}

For this accident analysis, it is assumed that the product receiving and shipping warehouse would be damaged when a major tornado, with associated tornado debris missiles, sweeps across the building in 30 seconds. It is assumed that a tornado wind-driven missile would hit a pallet of four drums and that all four drums would rupture and release their entire contents. In view of the close packing of drums within this building, the assumption of an entire pallet being affected is reasonable. It is assumed that all of the powder released from the drums becomes airborne with $5 \%$ in the respirable size range (this assumption is similar to that made in 
the Engineering Analysis Report for accidents involving $\mathrm{U}_{3} \mathrm{O}_{8}$, such as during defluorination of $\mathrm{UF}_{6}$ ). There would be failure of the building structure and its confinement system so that $100 \%$ of the $\mathrm{UF}_{4}$ released from the drums would be released from the building. This situation would result in ground-level unfiltered release of $73 \mathrm{~kg}(160 \mathrm{lb})$ for 30-gallon drums or $133 \mathrm{~kg}(293 \mathrm{lb})$ for 55-gallon drums. The released material would be highly dispersed by the tornadic winds. The release is assumed to continue for a 30 -second period. The frequency of this event $\left(5 \times 10^{-4} / \mathrm{yr}\right)$ is assumed to be the same as for the earthquake event in the Engineering Analysis Report. It should be noted that the tornado accident analyzed in the Engineering Analysis Report assumed that the entire product receiving and shipping warehouse would be destroyed so the material at risk was the entire contents of the warehouse. 


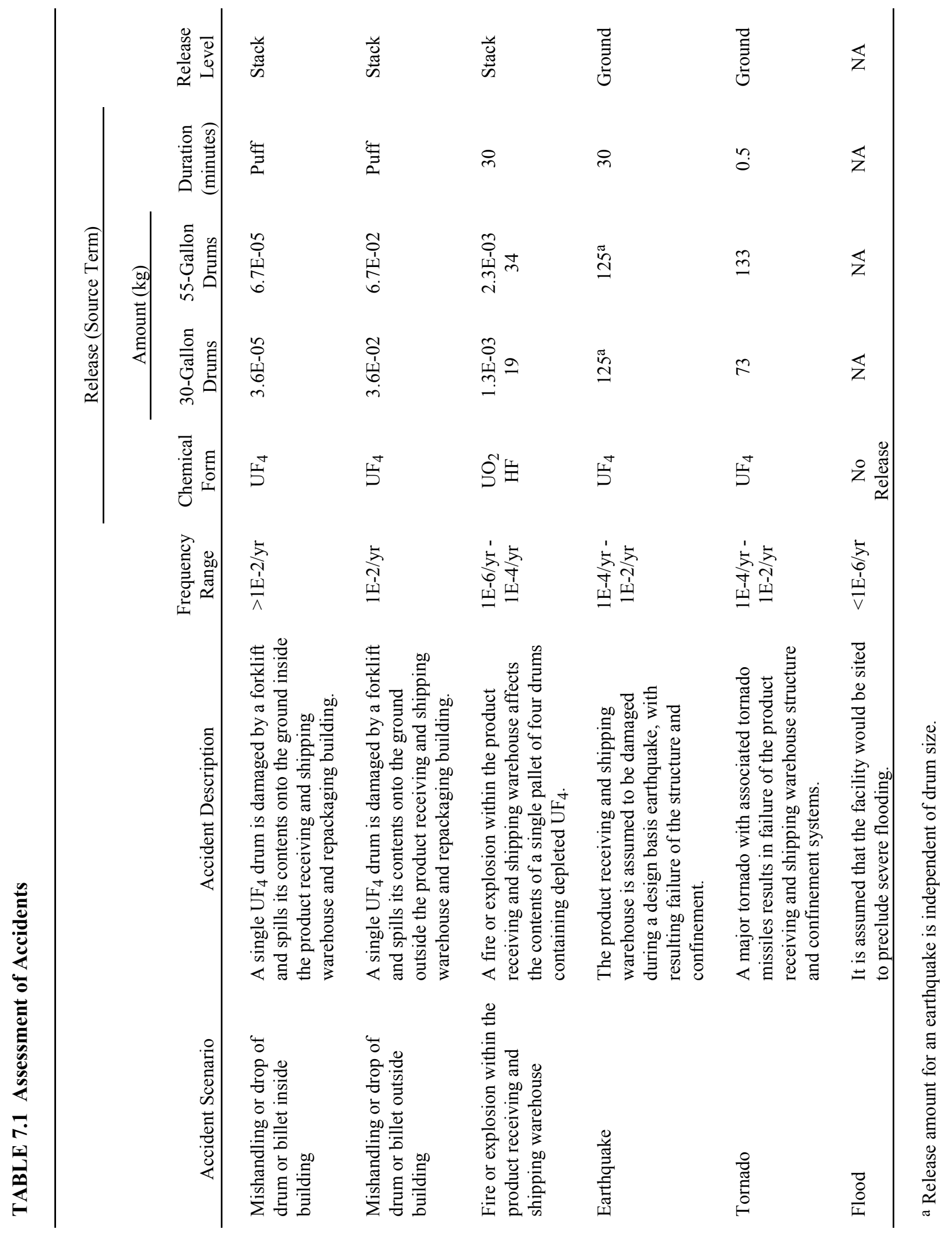




\section{TRANSPORTATION}

Intrasite transportation of radioactive materials would be limited to transport of drums from the product receiving area to the shipping area of the product receiving and shipping warehouse; transport of damaged drums from the product receiving area to the repackaging area in the product receiving and shipping warehouse; and transport of compliant drums by forklift from the shipping area to the disposal site.

Low-level radioactive waste (LLW) would not be a routine by-product of the wasteform facility. Any LLW that would be generated from spent HEPA filters or as a result of drums being damaged would be packaged in accordance with DOE or NRC/Agreement State requirements and transported by forklift to the shipping area for storage until appropriate disposal was arranged. Hazardous waste materials and LLMW (e.g., waste cleaning solutions, spent lubricants) requiring special treatment before disposal would be packaged and transported by forklift to the shipping area of the product receiving and shipping warehouse for treatment and disposal off-site.

Off-site transportation of radioactive material would be limited to receipt of drums of $\mathrm{UF}_{4}$ that were shipped by truck or rail, except for out-shipment of hazardous and/or LLMW for disposal. Tables $8.1 \mathrm{a}$ and $8.1 \mathrm{~b}$ summarize the materials and supplies received at the wasteform facility for the original inventory and the new inventory, respectively. For transport by truck, it is assumed that the truck would have a net payload of $19,545 \mathrm{~kg}(43,000 \mathrm{lb})$ and could convey either 28 55-gallon drums or 48 30-gallon drums. For transportation by rail, it is assumed that a single railcar would have a payload of $54,545 \mathrm{~kg}(120,000 \mathrm{lb})$ and could convey either 76 55-gallon drums or 132 30-gallon drums. A single rail shipment is assumed to have four railcars. 
TABLE 8.1a Off-Site Transport of Supplies and Input Materials for the Wasteform Facility, Original Inventory

\begin{tabular}{|c|c|c|c|c|}
\hline \multirow[b]{2}{*}{ Item } & \multicolumn{2}{|c|}{ 30-Gallon Drums } & \multicolumn{2}{|c|}{ 55-Gallon Drums } \\
\hline & Truck & Rail & Truck & Rail \\
\hline \multicolumn{5}{|l|}{ Transported Material } \\
\hline Type/chemical & $\mathrm{UF}_{4}$ & $\mathrm{UF}_{4}$ & $\mathrm{UF}_{4}$ & $\mathrm{UF}_{4}$ \\
\hline Physical form & $\begin{array}{l}\text { Solid, } \\
\text { granular }\end{array}$ & $\begin{array}{l}\text { Solid, } \\
\text { granular }\end{array}$ & $\begin{array}{l}\text { Solid, } \\
\text { granular }\end{array}$ & $\begin{array}{l}\text { Solid, } \\
\text { granular }\end{array}$ \\
\hline $\begin{array}{l}\text { Chemical composition/ } \\
\text { temperature, pressure }\end{array}$ & $\mathrm{UF}_{4} / \mathrm{ambient}$ & $\mathrm{UF}_{4} / \mathrm{ambient}$ & $\mathrm{UF}_{4} / \mathrm{ambient}$ & $\mathrm{UF}_{4} / \mathrm{ambient}$ \\
\hline \multicolumn{5}{|l|}{ Packaging } \\
\hline Type & 30-gal drum & 30-gal drum & 55-gal drum & 55-gal drum \\
\hline Container volume $\left(\mathrm{m}^{3}\right)$ & 0.11 & 0.11 & 0.21 & 0.21 \\
\hline Certified by & DOT & DOT & DOT & DOT \\
\hline Identifier & Varies & Varies & Varies & Varies \\
\hline Container weight $(\mathrm{kg})$ & 45 & 45 & 34 & 34 \\
\hline Material weight (kg) & 364 & 364 & 667 & 667 \\
\hline Chemical content (wt\%) & $100 \% \mathrm{UF}_{4}$ & $100 \% \mathrm{UF}_{4}$ & $100 \% \mathrm{UF}_{4}$ & $100 \% \mathrm{UF}_{4}$ \\
\hline \multicolumn{5}{|l|}{ Shipments } \\
\hline Average volume $\left(\mathrm{m}^{3}\right) / \mathrm{yr}$ & 7,796 & 7,796 & 7,797 & 7,797 \\
\hline Packages/year & 68,680 & 68,680 & 37,450 & 37,450 \\
\hline Packages/life of project & $1,373,000$ & $1,373,000$ & 749,000 & 749,000 \\
\hline Packages/shipment & 48 & 528 & 28 & 304 \\
\hline Shipments/year & 1,431 & 131 & 1,338 & 124 \\
\hline Shipments/life of project & 28,620 & 2,620 & 26,760 & 2,480 \\
\hline \multicolumn{5}{|l|}{ Form of Transport/Routing } \\
\hline Form of transportation & Truck & Rail & Truck & Rail \\
\hline Destination - facility type & $\begin{array}{l}\text { Wasteform } \\
\text { facility }\end{array}$ & $\begin{array}{l}\text { Wasteform } \\
\text { facility }\end{array}$ & $\begin{array}{l}\text { Wasteform } \\
\text { facility }\end{array}$ & $\begin{array}{l}\text { Wasteform } \\
\text { facility }\end{array}$ \\
\hline
\end{tabular}


TABLE 8.1b Off-Site Transport of Supplies and Input Materials for the Wasteform Facility, New Inventory

\begin{tabular}{|c|c|c|c|c|}
\hline \multirow[b]{2}{*}{ Item } & \multicolumn{2}{|c|}{ 30-Gallon Drums } & \multicolumn{2}{|c|}{ 55-Gallon Drums } \\
\hline & Truck & Rail & Truck & Rail \\
\hline \multicolumn{5}{|l|}{ Transported Material } \\
\hline Type/chemical & $\mathrm{UF}_{4}$ & $\mathrm{UF}_{4}$ & $\mathrm{UF}_{4}$ & $\mathrm{UF}_{4}$ \\
\hline Physical form & $\begin{array}{l}\text { Solid, } \\
\text { granular }\end{array}$ & $\begin{array}{l}\text { Solid, } \\
\text { granular }\end{array}$ & $\begin{array}{l}\text { Solid, } \\
\text { granular }\end{array}$ & $\begin{array}{l}\text { Solid, } \\
\text { granular }\end{array}$ \\
\hline $\begin{array}{l}\text { Chemical composition/ } \\
\text { temperature, pressure }\end{array}$ & $\mathrm{UF}_{4} / \mathrm{ambient}$ & $\mathrm{UF}_{4} / \mathrm{ambient}$ & $\mathrm{UF}_{4} / \mathrm{ambient}$ & $\mathrm{UF}_{4} /$ ambient \\
\hline \multicolumn{5}{|l|}{ Packaging } \\
\hline Type & 30-gal drum & 30-gal drum & 55-gal drum & 55-gal drum \\
\hline Container volume $\left(\mathrm{m}^{3}\right)$ & 0.11 & 0.11 & 0.21 & 0.21 \\
\hline Certified by & DOT & DOT & DOT & DOT \\
\hline Identifier & Varies & Varies & Varies & Varies \\
\hline Container weight (kg) & 45 & 45 & 34 & 34 \\
\hline Material weight (kg) & 364 & 364 & 667 & 667 \\
\hline Chemical content (wt\%) & $100 \% \mathrm{UF}_{4}$ & $100 \% \mathrm{UF}_{4}$ & $100 \% \mathrm{UF}_{4}$ & $100 \% \mathrm{UF}_{4}$ \\
\hline \multicolumn{5}{|l|}{ Shipments } \\
\hline Average volume $\left(\mathrm{m}^{3}\right) / \mathrm{yr}$ & 7,854 & 7,854 & 7,853 & 7,853 \\
\hline Packages/year & 69,160 & 69,160 & 37,720 & 37,720 \\
\hline Packages/life of project & $1,729,000$ & $1,729,000$ & 943,000 & 943,000 \\
\hline Packages/shipment & 48 & 528 & 28 & 304 \\
\hline Shipments/year & 1,441 & 131 & 1,348 & 125 \\
\hline Shipments/life of project & 36,025 & 3,275 & 33,700 & 3,125 \\
\hline \multicolumn{5}{|l|}{ Form of Transport/Routing } \\
\hline Form of transportation & Truck & Rail & Truck & Rail \\
\hline Destination - facility type & $\begin{array}{l}\text { Wasteform } \\
\text { facility }\end{array}$ & $\begin{array}{l}\text { Wasteform } \\
\text { facility }\end{array}$ & $\begin{array}{l}\text { Wasteform } \\
\text { facility }\end{array}$ & $\begin{array}{l}\text { Wasteform } \\
\text { facility }\end{array}$ \\
\hline
\end{tabular}




\section{PERMITTING AND REGULATORY COMPLIANCE}

This section addresses requirements for disposal of depleted $\mathrm{UF}_{4}$ at a DOE facility subject to DOE orders and at a commercial disposal facility subject to NRC or Agreement State regulations. Because depleted $\mathrm{UF}_{4}$ would be disposed of at an arid or semiarid site, the waste acceptance criteria (WAC) of the NTS and the radioactive license conditions for the private Envirocare facility in Utah are discussed as representative disposal requirements under the two regulatory regimes (DOE and NRC). Disposal at NTS would be in accordance with DOE orders. Disposal at Envirocare would in accordance with a radioactive material license issued by the State of Utah because Utah is a state with which the NRC has executed an agreement to delegate regulatory authority over land disposal facilities for LLW. As in the Engineering Analysis Report, the scope of this section is limited to nuclear and radiation safety requirements promulgated by DOE or NRC and Agreement States pursuant to the Atomic Energy Act of 1954 and other laws specifying radioactive waste management procedures.

Low-level radioactive waste is defined by the Low-Level Radioactive Waste Policy Amendments Act of 1985 (LLWPAA) (Pub. L. 99-240) as radioactive material that (A) is not high-level radioactive waste, spent nuclear fuel, or by-product material [as defined in Section 11(e)(2) of the Atomic Energy Act]; and (B) the NRC, consistent with existing law and in accordance with paragraph (A), classifies as low-level radioactive waste. The depleted uranium of interest would not be spend nuclear fuel because it was not irradiated in a nuclear reactor; it would not be high-level radioactive waste because it did not result from the reprocessing of spent nuclear fuel; and it would not be Section 11(e)(2) by-product material because it is not tailing or waste produced by the extraction or concentration of uranium from ore. Also, being uranium, it is not transuranic waste. Thus, by elimination, depleted uranium would appear to be LLW. Hightower and Trabalka (2000) have concluded that depleted uranium metal and oxides are LLW. The results of their analysis would apply to depleted $\mathrm{UF}_{4}$.

\subsection{COMMERCIAL DISPOSAL FACILITIES}

\subsubsection{Overview}

DOE policy as stated in DOE M 435.1-1, Radioactive Waste Manual, Section 1.2.F(4), is that radioactive waste shall be treated, stored, and, in the case of LLW, disposed of at the site where the waste was generated, if practical; or at another DOE facility. However, if DOE capabilities are not practical or not cost effective, an exemption may be approved by the Field Element Manager after consultation with the Office of the Assistant Secretary for Environment, Safety and Health and notice to DOE Headquarters to allow the use of non-DOE facilities if several requirements are met. Among these requirements are documentation that the use of non-DOE facilities would be cost effective and in the best interest of DOE, and that the waste is sufficiently characterized and certified to meet the receiving facility's waste acceptance criteria. 
Regulations governing disposal of LLW promulgated by Agreement States must be in accordance with the regulations promulgated by the NRC in 10 CFR Part 61, Licensing Requirements for Land Disposal of Radioactive Waste. Part 61 establishes performance objectives, technical requirements, and licensing procedures and criteria for "near-surface" disposal of LLW. Regulation 10 CFR 61.7 explains near-surface disposal involving disposal in the uppermost portion of the earth, (approximately $30 \mathrm{~m}[98 \mathrm{ft}]$ ), although burial deeper than $30 \mathrm{~m}$ may also be satisfactory. Near-surface disposal includes engineered facilities built totally or partially above grade, provided they have protective earthen covers. In accordance with the Engineering Analysis Report, a mined-cavity disposal facility is assumed to be $180 \mathrm{~m} \mathrm{(590} \mathrm{ft)}$ below the surface. This depth would be too far below the surface to be considered near-surface disposal. Therefore, the technical requirements of 10 CFR Part 61 would not apply to a mined cavity, although the performance objectives would. Technical requirements would probably be developed by the licensing agency on a case-specific basis.

A cornerstone of NRC's regulatory system is to ensure stability of the waste and the disposal site once the waste has been emplaced and covered. To reduce migration of radionuclides, access of water to the waste should be minimized. The degree of stability of the waste required depends on how radioactive the waste is, as well as on other factors such as mobility. A lesser degree of stability is required for low activity, low-mobility waste than for high-activity or high-mobility waste. Stability may be inherent in the waste form itself or may be achieved by processing the waste to a stable form or by placing the waste in a disposal container or container that provides stability after disposal [10 CFR 61.56(b)(1)].

The NRC has established four performance objectives:

1. Protection of the general population from releases of radioactivity (10 CFR 61.41) - Concentrations of radioactive material which may be released to the general environment in groundwater, surface water, air, soil, plants, or animals must not result in an annual dose exceeding an equivalent of $25 \mathrm{mrem}$ $(0.25 \mathrm{mSv})$ to the whole body, $75 \mathrm{mrem}(0.75 \mathrm{mSv})$ to the thyroid, and $25 \mathrm{mrem}(0.25 \mathrm{mSv})$ to any other organ of any member of the public. Also reasonable effort should be made to maintain releases in effluents to the general environment as low as is reasonably achievable (ALARA)

2. Protection of individuals from inadvertent intrusion (10 CFR 61.42) Design, operation, and closure of a land disposal facility must ensure protection of any individual inadvertently intruding into the disposal site and occupying the site or contacting the waste and any time after active institutional controls over the disposal site are removed.

3. Protection of individuals during operations (10 CFR 61.43) - Operations of the facility must be conducted in compliance with the standards for radiation protection set out in 10 CFR Part 20, except for releases of radioactivity in 
effluents, which shall be governed by 10 CFR 61.41. Every reasonable effort shall be made to maintain radiation exposures ALARA.

4. Stability of the site after closure (10 CFR 61.44) - A disposal facility must be sited, designed, used, operated, and closed to achieve long-term stability of the disposal site and to eliminate to the extent practicable the need for ongoing active maintenance of the disposal site following closure so that only surveillance, monitoring, or minor custodial care are required.

\subsubsection{Technical Requirements}

To achieve these performance objectives, the NRC imposes several technical requirements, as discussed below.

\subsubsection{Waste Classification}

The NRC classifies waste suitable for near-surface disposal as Class A, Class B, or Class $\mathrm{C}$ on the basis of the concentration of certain long-lived radionuclides and their shorter-lived precursors and on the basis of the concentration of certain shorter-lived radionuclides for which requirements on institutional controls are effective (10 CFR 61.55). Waste with greater concentrations of these radionuclides than Class $\mathrm{C}$ waste (greater-thanClass-C waste) is not suitable for near-surface disposal. Waste with the smallest concentration of these radionuclides is Class A waste. The radionuclides of uranium are not used in the NRC classification scheme; therefore, depleted $\mathrm{UF}_{4}$ would be Class A waste [10 CFR 61.55(a)(6)]. Class A waste need not be segregated if it has structural stability [10 CFR 61.55(a)(2)].

\subsubsection{Disposal Site Suitability}

Regulation 10 CFR 61.50 requires that disposal sites have certain minimum characteristics. These include the following: (1) the site must be capable of characterization; (2) projected population growth and future development should not impair achievement of the performance objectives; (3) the site must avoid natural resources that might be exploited; (4) the site must be well-drained, free of flooding, and not be in a 100 -year floodplain, coastal highhazard area, or wetland; (5) groundwater should not be discharged to the surface within the disposal site; and (6) areas where tectonic processes such as faulting, folding, seismic activity, or vulcanism may occur must be avoided. 


\subsubsection{Disposal Site Design}

Regulation 10 CFR 61.51 requires that site design features must be directed toward long-term isolation and avoidance of the need for continuing active maintenance after site closure. These features include covers designed to minimize water infiltration, to direct percolating or surface water away from the disposed waste, and to resist degradation by surface geological processes.

\subsubsection{Disposal Facility Operation and Closure}

Regulation 10 CFR 61.52 addresses land disposal facility operation and site closure. Its requirements include the following: (1) Class A waste must be segregated from other classes of waste if it has not been stabilized; (2) wastes must be emplaced in a manner that maintains disposal container integrity during emplacement, minimizes void spaces between packages, and permits the void spaces to be filled with earth or other materials to reduce future subsidence; and (3) buffer zone must be maintained between any buried waste and the boundary of the disposal site.

\subsubsection{Waste Characteristics}

Any class of LLW must meet certain minimum requirements given in 10 CFR 61.56(a). These are: (1) waste must not be packaged for disposal in cardboard or fiberboard boxes; (2) liquid waste must be solidified or packaged in sufficient absorbent material to absorb twice the volume of the liquid; (3) solid waste containing liquid shall contain as little free-standing and noncorrosive liquid as is reasonably achievable, but in no case shall the liquid content exceed $1 \%$ of the volume; (4) waste must not be readily capable of detonation or of explosive decomposition or reaction at normal pressures and temperatures, or of explosive reaction with water; (5) waste must not contain, or be capable of generating, quantities of toxic gases, vapors, or fumes harmful to persons transporting, handling, or disposing of the waste, this does not apply to radioactive gaseous waste packaged in accordance with paragraph 10 CFR 61.56(a)(7); (6) waste must not be pyrophoric - pyrophoric materials contained in waste shall be treated, prepared, and packaged to be nonflammable; (7) waste in a gaseous form must be packaged at a pressure that does not exceed 1.5 atmospheres at $20^{\circ} \mathrm{C}\left(68^{\circ} \mathrm{F}\right)$, total activity must not exceed 100 curies per package; and (8) waste containing hazardous, biological, pathogenic, or infectious material must be treated to reduce to the maximum extent practical the potential hazard from the nonradiological material. Regulation 10 CFR 61.56(b) contains stability requirements to ensure that the waste does not structurally degrade and affect overall stability of the site through slumping, collapse, or other failure of the disposal unit and thereby lead to water infiltration. 


\subsubsection{Analysis}

Uranium tetrafluoride is granular, nonvolatile, nonhygroscopic, and only slightly soluble in water. However, it reacts very slowly with moisture at ambient temperatures to form $\mathrm{UO}_{2}$ and HF, which would enhance the corrosion rate of disposal containers. Uranium tetrafluoride, being granular, does not have inherent stability; therefore, it must be disposed of in a rigid container. To maintain stability, which is compromised by corrosive gas formation, the disposal container used should strongly resist infiltration of moisture. It has been assumed in this analysis that the potential evolution of fluoride ions from chemisorbed HF would be eliminated during the process of converting from $\mathrm{UF}_{6}$ to $\mathrm{UF}_{4}$ by heating the depleted $\mathrm{UF}_{4}$ product. It is also assumed that drum filing would be performed under inert conditions to prevent airborne moisture from being retained in the interior of the disposal containers. The reactivity rate with moisture has been considered to be slow enough for $\mathrm{UF}_{4}$ to be considered not "reactive" as the term is generally interpreted in the context of waste management (Croff et al. 2000).

\subsubsection{Envirocare Radioactive Material License}

The Envirocare facility has been issued Radioactive Material License \#UT 2300249 by the Utah Department of Environmental Quality, Division of Radiation Control. The current version of the license (Amendment 09) expires October 22, 2003 (Utah Department of Environmental Quality 2000). Envirocare has developed waste acceptance guidelines (Envirocare 1999) that provide waste generators information about the capabilities and requirements of Envirocare's disposal facility. The current license does not appear to have any provisions in Condition 16 ("Prohibition") that would prohibit the disposal of depleted UF 4 . The only class of LLW allowed to be disposed of by Condition 9C is Class A waste, but depleted $\mathrm{UF}_{4}$ is Class A waste in the NRC classification system. Condition 8 limits the concentration of depleted uranium to not more than $3.7 \times 10^{5} \mathrm{pCi} / \mathrm{g}\left(1.4 \times 10^{4} \mathrm{~Bq} / \mathrm{g}\right)$. It has been assumed that the average isotopic composition of depleted uranium is $0.001 \% \mathrm{U}-234,0.25 \% \mathrm{U}-235$, and $99.75 \%$ U-238. This composition yields a specific activity of $4 \times 10^{5} \mathrm{pCi} / \mathrm{g}\left(1.5 \times 10^{4} \mathrm{~Bq} / \mathrm{g}\right)$ for depleted uranium. Uranium tetrafluoride is $76 \%$ uranium by weight; therefore, its average specific activity is $3 \times 10^{5} \mathrm{pCi} / \mathrm{g}\left(1.1 \times 10^{4} \mathrm{~Bq} / \mathrm{g}\right)$, which is below the limit. However, if there were significant variations about the average isotopic composition, it is conceivable that the limit could be exceeded for some containers. Therefore, it would be necessary to carefully characterize the waste before to shipment to the disposal facility.

Condition 9A, which does not apply to DOE waste disposed of at the Envirocare facility, provides that prior to receiving an initial shipment from a generator, the Executive Secretary to the Utah Radiation Control Board shall receive documentation of approval of the waste for export, where this approval would be given by a compact or state, to the extent a state can exercise such approval. The LLWPAA, assigns to the federal government responsibility for providing disposal of LLW generated by DOE. Authority of individual states or interstate compacts under the LLWPAA does not apply to DOE waste. 


\subsection{DOE DISPOSAL FACILITIES}

\subsubsection{Overview}

DOE is responsible for the LLW it generates under the LLWPAA, and its contractors are subject to DOE orders. The primary applicable order is DOE O 435.1, Radioactive Waste Management, which states four general requirements that radioactive waste be managed (1) to protect the public from exposure to radiation from radioactive materials in accordance with DOE 5400.5, Radiation Protection of the Public and the Environment; (2) to protect the environment in accordance with DOE 5400.1, General Environmental Protection Program, DOE 5400.5; (3) to protect workers in accordance with 10 CFR Part 835, Occupational Radiation Protection, and DOE O 440.1A, Worker Protection Management for DOE Federal and Contractor Employees; and (4) to comply with applicable federal, state, and local laws and regulations, and with applicable Executive Orders.

DOE O 435.1 also requires that all radioactive waste be managed in accordance with the requirements in DOE M 435.1-1, Radioactive Waste Management Manual (the Manual). The Manual requires that certain waste acceptance requirements be imposed by LLW disposal facilities. These requirements are substantially the same as the minimum waste requirements in 10 CFR 61.56(a). DOE does not have a waste classification system applicable to all disposal facilities; rather, it allows for site-specific waste classification systems.

\subsubsection{Performance Objectives}

The Manual establishes performance objectives limiting radiological dose to representative members of the public and release of radon at the boundary of the facility. Radiological dose to representative members of the public shall not exceed 25 mrem $(0.25 \mathrm{mSv})$ in a year total effective dose equivalent (TEDE) from all exposure pathways, excluding the dose from radon and its progeny in air. Dose to representative members of the public via the air pathway shall not exceed $10 \mathrm{mrem}(0.10 \mathrm{mSv})$ in a year TEDE, excluding the dose from radon and its progeny in air. Release of radon shall be less than an average flux of $20 \mathrm{pCi} / \mathrm{m}^{2} / \mathrm{s}$ $\left(0.74 \mathrm{~Bq} / \mathrm{m}^{2} / \mathrm{s}\right)$ at the surface of the disposal facility. Alternatively, a limit of $0.5 \mathrm{pCi} / \mathrm{L}$ $(0.0185 \mathrm{~Bq} / \mathrm{L})$ of air may be applied at the boundary of the facility.

\subsubsection{Performance Assessment}

The Manual requires that a site prepare a performance assessment (PA) for all wastes disposed of after September 1988. The PA is required to include calculations (for a 1,000-year period after closure) of potential doses to representative future members of the public and potential releases from the facility. These calculations are intended to provide a reasonable 
expectation that the performance objectives will not be exceeded. A PA is used to establish limits on concentrations of radionuclides for disposal. In establishing these limits, a PA should also include inadvertent intruder scenarios. The intruder analyses are required to use performance measures for chronic and acute scenarios, respectively, of 100 mrem $(1 \mathrm{mSv})$ in a year and $500 \mathrm{mrem}(5 \mathrm{mSv})$ TEDE excluding radon in air.

\subsubsection{Composite Analysis}

For the purpose of planning radiation protection activities and future use commitments and to minimize the likelihood that current LLW disposal activities will result in the need for future corrective or remedial actions, a site-specific radiological composite analysis is required. Such an analysis accounts for all sources of radioactive material that may be left at a DOE site and may interact with the LLW disposal facility, contributing to the dose projected to a hypothetical member of the public from existing and future disposal facilities.

\subsubsection{Site Evaluation and Facility Design}

Proposed sites for LLW facilities must be evaluated within the context of environmental and geotechnical characteristics and human activities. As a minimum, it is necessary to demonstrate whether the site is (1) located to accommodate the projected volume of waste to be received; (2) located in a floodplain, tectonically active area, or in the zone of water table fluctuation; and (3) located to achieve long-term stability and to minimize, to the extent practical, the need for active maintenance following final closure. The minimum requirements for the design of a LLW disposal facility include the following: (1) LLW systems and components must be designed to maintain waste confinement; (2) ventilation, if applicable, must be provided through an appropriate filtration system to maintain the release of radioactive material in airborne effluents within applicable requirements; and (3) the contact of waste with water during and after disposal must be minimized to the extent practical.

\subsubsection{NTS Waste Acceptance Criteria}

Waste disposed of at NTS must meet the requirements, terms, and conditions of the Nevada Test Site Waste Acceptance Criteria (NTSWAC) (DOE 1999). Most of the concerns that must be addressed would not be expected to be issues for disposal of depleted $\mathrm{UF}_{4}$. For example, the waste is uniform, well characterized, and nontransuranic. However, some conditions may be of concern, as discussed below in Sections 9.2.2.1 through 9.2.2.4. 


\subsubsection{Action Levels for Characterization and Reporting}

Section 3.1.2 of the NTSWAC provides for radionuclide concentration limits for disposal. If a limit is exceeded, waste may be acceptable for disposal upon review by DOE's Nevada Operations Office. The limit for U-238 as given in Appendix E of the NTSWAC is $5.9 \times 10^{10} \mathrm{~Bq} / \mathrm{m}^{3}$. The average specific activity of depleted $\mathrm{UF}_{4}$ is $3.0 \times 10^{7} \mathrm{Ci} / \mathrm{g}$ or $1.1 \times 10^{4} \mathrm{~Bq} / \mathrm{g}$ or $1.1 \times 10^{10} \mathrm{~Bq} /$ te. To be within the limit, the density of depleted $\mathrm{UF}_{4}$ within the disposal containers must be less than $5.4 \mathrm{te} / \mathrm{m}^{3}$. However, if there is significant variation in the isotopic composition of depleted uranium, a smaller density would be needed to stay below the limit for some disposal containers. Because $\mathrm{UF}_{4}$ is taken to have a bulk density of $3.2 \mathrm{te} / \mathrm{m}^{3}$, the action level for reporting is not exceeded.

\subsubsection{Particulates}

Section 3.1.6 of the NTSWAC provides that fine particulate wastes shall be immobilized so that the waste package contains no more than 1 weight percent of less than $10-\mu$-diameter particles, or 15 weight percent of less than $200-\mu \mathrm{m}$-diameter particles. Waste that is known to be in a fine particulate form, or in a form that can be mechanically or chemically transformed to a particulate during handling and interim storage, must be immobilized. Secure packaging may be used in place of immobilization. Examples of acceptable packaging are overpacking (e.g., a 55-gallon drum inside an 85-gallon drum) and steel boxes. Drums and wooden boxes with sealed 6-mil (minimum) liners will also satisfy this requirement.

\subsubsection{Stabilization}

Section 3.1.8.2 of the NTSWAC requires that chemical stability and compatibility must be demonstrated to ensure that no reactions occur and that significant quantities of harmful gases, vapors, or liquids are not generated. In Section 9.1, it was stated that it has been assumed in this analysis that the potential evolution of fluoride ions from chemisorbed HF would be removed during the process of converting from $\mathrm{UF}_{6}$ to $\mathrm{UF}_{4}$ by heating the depleted $\mathrm{UF}_{4}$ product. It has also been assumed that drum filing would be performed under inert conditions to exclude retention of airborne moisture in the interior of the disposal containers. However, there should be a demonstration of the nonreactive nature of $\mathrm{UF}_{4}$ as actually produced and packaged in steel drums before shipment to NTS to ensure compliance with this condition and the waste characterization requirements of Section 4.0 of the NTSWAC. It should be noted that, as discussed in Section 1.1, 1,870 te of depleted $\mathrm{UF}_{4}$ in the form of salts, residues, and dust has been shipped from the DOE FEMP in Ohio to the NTS for disposal. Prior to the shipments, it was demonstrated that this waste met DOT shipping requirements and the NTSWAC. 


\subsubsection{Weight of Disposal Container}

Section 3.2.6 requires that the weight of a box not exceed 4,082 $\mathrm{kg}(9,000 \mathrm{lb})$ and that the weight of a drum not exceed $544 \mathrm{~kg}(1,200 \mathrm{lb})$. With a density of $3.2 \mathrm{~g} / \mathrm{cm}^{3}$, the contents of a 55 -drum would weigh $665.5 \mathrm{~kg}(1,467 \mathrm{lb})$ if fully loaded, and the contents of a 30-gallon drum would weigh $363 \mathrm{~kg}(800 \mathrm{lb})$ if fully loaded. A fully loaded 55-gallon drum would not comply with this weight limitation; a fully loaded 30-gallon drum would comply. This requirement is based on an Occupational Safety Health Administration limit on the loading of hoists (forklifts) currently used at NTS. 


\section{PRELIMINARY SCHEDULE ESTIMATES}

An estimated schedule for the entire life cycle of the depleted $\mathrm{UF}_{4}$ disposal facility is shown in Figure 10.1. ${ }^{1}$ The schedule and rationale presented used here mirror the schedule and rationale in the Engineering Analysis Report.

After a DOE Record of Decision (ROD) has been issued, there would be a period of approximately 1 year for developing management plans, obtaining approvals, and initial budgeting. Next there would be a period of approximately 3 years for developing and testing the form for the depleted $\mathrm{UF}_{4}$ and for generating baseline design parameters, such as particle size distribution and density. Also included in this period would be computer modeling of the proposed disposal sites. Parallel to these technology verification tasks would be a design task, a safety approval, and NEPA process task. It is estimated that after 5 years, these tasks should be far enough along that a construction application could be submitted. After 2 more years, the final design and final safety analysis would be completed so that construction approval would be granted (at the end of the seventh year).

Licensing and permitting of a disposal facility could potentially add 5 to 10 years to the schedule. In general, the license application is based on site-specific disposal facility design and safety assessments that must demonstrate compliance of the proposed facility with regulatory requirements. Licensing typically involves complex legal and political procedures, intensive technical reviews by the regulatory body, and interaction with the public. A licensing and permitting strategy would be employed to anticipate and avoid needless delay. However, it should be noted that no new commercial repository for low-level wastes has been constructed in the United States since the passage of the Low-Level Radioactive Waste Policy Act of 1980. In eight U.S. states, the site-selection process is in some stage of progress. A total of four sites already have been selected in Nebraska (Central Interstate Compact), North Carolina (Southeast Compact), California (Southwest Compact), and Texas (pending the Texas Compact) and are now in the licensing process.

DOE procurement is another element that would have to be factored into the schedule so that excessive delays would be avoided. Construction would then follow, with an overall schedule of 31 years. However, licensing and permitting remain as the most uncertain stages that could significantly increase schedule. Because a key factor during licensing and permitting currently is public acceptance, disposal facilities in some cases are being colocated at sites where nuclear facilities already exist. The use of an existing wasteform facility or approved disposal facility might shorten the time periods shown in Figure 10.1.

Once the disposal facility is full, or disposal operations are stopped for other reasons, the processes known as "closure" and "post-closure" begins. The closure process includes steps to secure the facility, such as covering or sealing the disposal areas; compiling documents, and

\footnotetext{
${ }^{1}$ For reader convenience, figures referred to in Section 10 are placed at the end of the section.
} 
performing safety assessments. The licensee and the regulating body would continue to monitor for radioactivity in groundwater, air, soil, and vegetation. Staff from the regulating body would continue to inspect the site and monitor site operator post-closure operations. Several hundreds of years are foreseen for post-closure institutional control, which may include access control, maintenance, site monitoring, record keeping, and corrective actions, if required.

The time periods associated with the post closure (1-10 years), active institutional care (1-100 years), and passive institutional care (101-300 years) are not shown in Figure 10.1, consistent with the Engineering Analysis Report.

The schedule shown in Figure 10.1 is based on experience with actual construction and operations of nonreactor nuclear-type facilities. A "fast track" approach is clearly possible, which would decrease the time to operations. However, for comparison of discounted life-cycle costs and environmental impacts between the various disposal options and chemical forms, the decision was made in this analysis to apply the generic schedule shown in the Engineering Analysis Report for disposal of $\mathrm{UO}_{2}$ and $\mathrm{U}_{3} \mathrm{O}_{8}$, as appropriate, for disposal of depleted $\mathrm{UF}_{4}$. A shorter time to operations would result in higher discounted life-cycle costs and greater annual environmental impacts compared with the other chemical forms considered for disposal.

\subsection{WASTEFORM FACILITY}

The construction of the wasteform facility would begin in year 8. As roads and rail lines are constructed, the large, but uncomplicated, metal framed buildings of the wasteform facility would be erected, followed by installation and testing of equipment for decontamination and monitoring. It is expected that construction of the adjacent disposal facilities would not interfere with construction and/or operation of the wasteform facility.

\subsection{VAULT DISPOSAL FACILITY}

As shown in Figure 10.1, construction of the vault disposal facility would begin in year 10 and continue through year 35 (for the new inventory). Sufficient numbers of vaults would be constructed each year to accommodate the next year's anticipated deliveries of depleted $\mathrm{UF}_{4}$.

Disposal vault construction would include foundation construction and installation of the primary and secondary monitoring systems and data acquisition features, including sensors for monitoring. Initial construction would consist of development and improvement of the site and excavation and preparation of the disposal vaults. Construction of the vault facilities is intended to be a continuous process concurrent with the placement of the depleted $\mathrm{UF}_{4}$ drums. 
Closure activities would take place during the first three years after the facility ceased to accept waste. Closure includes decontamination of the wasteform facility, initial demolition of buildings, site development, closure of the vaults, site remediation, and monitoring of the vault performance and groundwater.

\subsection{ENGINEERED TRENCH DISPOSAL FACILITY}

As shown in Figure 10.1, construction of the engineered trench disposal facility would begin in year 10 and continue through year 35 (for the new inventory). Waste disposal could potentially occur after 1 month of preliminary excavation without waiting for the entire trench facility to be completed. (It should be noted that this analysis assumes the development of a single engineered trench per year.) This preliminary excavation would begin the continual process of simultaneously excavating and disposing, completing disposal in the first trench within a 12-month period.

Closure activities would be similar to those for the vault disposal facility.

\subsection{MINED-CAVITY DISPOSAL FACILITY}

Because mined-cavity construction is projected to require 7.5 years, construction activities would begin in year 3 so that the facility would be available to accept waste beginning in year 11 (see Figure 10.2). Facility construction would begin with site preparation, followed by construction of surface facilities (such as the product receiving and shipping warehouse, the ventilation house, and support facilities, including an emergency power generator for subsurface lighting and utilities). Construction of subsurface features (such as the access ramps and disposal drifts) would follow.

Closure activities would include demolition of surface facilities. The access ramps into the mined cavity would be backfilled (the drifts would already have been backfilled) and the area capped and fenced off after demolition. 


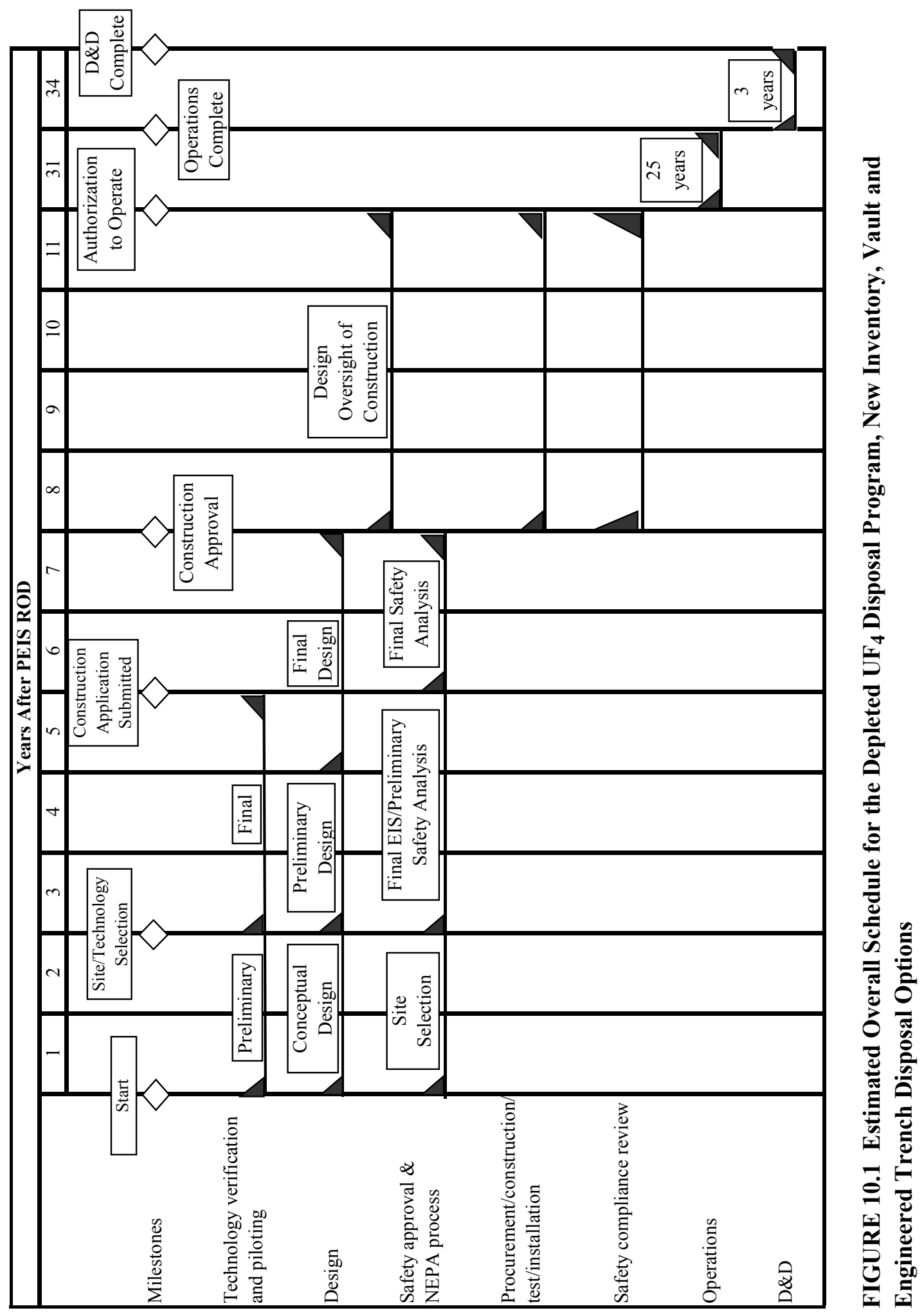




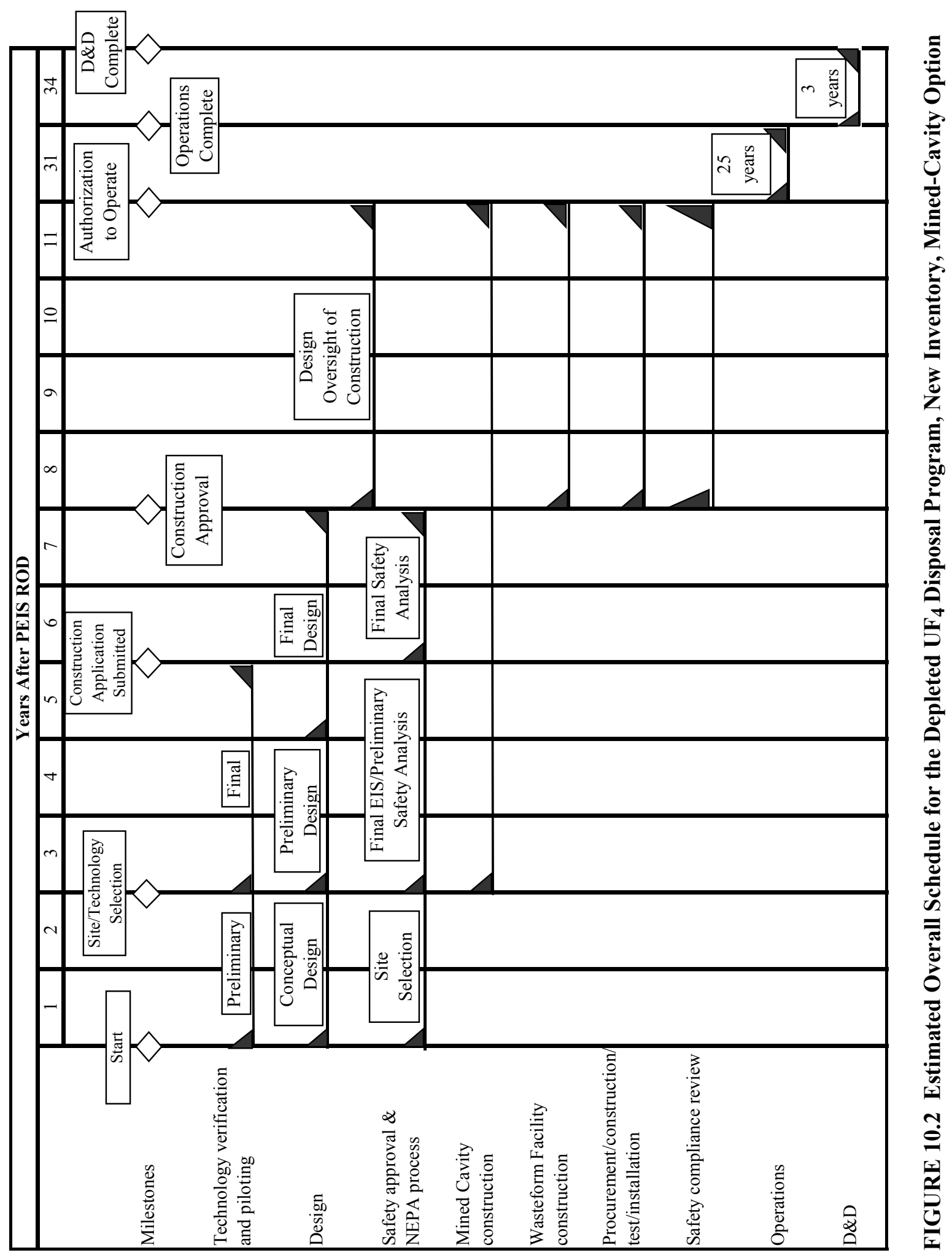




\section{PARAMETRIC DATA FOR DISPOSAL IN A MINED CAVITY}

Three disposal options - (1) engineered trench, (2) belowground vault, and (3) mined cavity - were considered in Sections 1 through 10 of this report. For comparative purposes, and to be consistent with the Engineering Analysis Report, the mined-cavity disposal option has been analyzed for both 30-gallon and 55-gallon drum sizes to develop engineering data in support of the parametric analysis. Details are presented in this section.

Tables $11.1^{1}$ through 11.13 incorporate pertinent factors and parameters into sets of parametric data. Three cases are considered for the amount of depleted uranium disposed of at the disposal facility: the entire original inventory $(100 \%$ case $)$; half of the original inventory ( $50 \%$ case); and one-quarter of the original inventory ( $25 \%$ case).

Tables 11.1a and 11.1b summarize annual input and output of product for 30-gallon drums and 55-gallon drums, respectively. Tables $11.2 \mathrm{a}$ and $11.2 \mathrm{~b}$ contain land use requirements for the wasteform facility for 30 -gallon drums and 55-gallon drums, respectively. Tables $11.3 \mathrm{a}$ and $11.3 \mathrm{~b}$ contain land use requirements for the mined-cavity disposal area for 30 -gallon drums and 55-gallon drums, respectively.

Tables $11.4 \mathrm{a}$ and $11.4 \mathrm{~b}$ contain construction resource requirements for the wasteform facility and the mined-cavity disposal area for 30-gallon drums and 55-gallon drums, respectively. Tables $11.5 \mathrm{a}$ and $11.5 \mathrm{~b}$ contain operations resource requirements for the wasteform facility and the mined-cavity disposal area for 30-gallon drums and 55-gallon drums, respectively.

Tables $11.6 \mathrm{a}$ and $11.6 \mathrm{~b}$ contain employment summaries for the wasteform facility and the mined-cavity disposal area for 30-gallon drums and 55-gallon drums, respectively.

Tables $11.7 \mathrm{a}$ and $11.7 \mathrm{~b}$ list construction emissions and wastes for the mined-cavity disposal area for 30-gallon drums and 55-gallon drums, respectively. Tables 11.8a and 11.8b list construction emissions and wastes for the wasteform facility for 30-gallon drums and 55-gallon drums, respectively.

Table 11.9 contains annual emissions and wastes from operation of the mined-cavity disposal facility. Tables 11.10a and $11.10 \mathrm{~b}$ contain annual emissions and wastes from operation of the wasteform facility for 30 -gallon drums and 55-gallon drums, respectively.

Tables $11.11 \mathrm{a}$ and $11.11 \mathrm{~b}$ contain transportation summaries for 30 -gallon drums and 55 -gallon drums, respectively.

\footnotetext{
${ }^{1}$ For reader convenience, tables and figures referred to in Section 11 are placed at the end of the section.
} 
Tables 11.12a, 11.12b, and $11.12 \mathrm{c}$ contain estimates of the number of construction workers (FTEs) needed by year for construction of the mined-cavity disposal area for the $100 \%$ case, the $50 \%$ case, and the $25 \%$ case, respectively. Tables $11.13 \mathrm{a}, 11.13 \mathrm{~b}$, and $11.13 \mathrm{c}$ contain estimates of the number of construction workers (FTEs) needed by year for construction of the wasteform facility for the $100 \%$ case, the $50 \%$ case, and the $25 \%$ case, respectively. FTEs are rounded to the nearest integer in these tables.

Figures 11.1 and 11.2 display the relative wasteform facility and mined-cavity underground footprint for each parametric case, respectively, for both 30-gallon and 55-gallon drums. Figures $11.3,11.4$, and 11.5 display the underground disposal facility footprint for $100 \%$, $50 \%$, and $25 \%$ of the original inventory, respectively. 
TABLE 11.1a Annual Input/Output Summary, 30-Gallon Drums

\begin{tabular}{lrrr}
\hline & \multicolumn{3}{c}{ Percentage of Original Inventory } \\
\cline { 2 - 4 } \multicolumn{1}{c}{ Parameter } & $100 \%$ & \multicolumn{1}{c}{$50 \%$} & $25 \%$ \\
\hline & & & \\
Received drums of UF 4 per year & 68,650 & 34,350 & 17,200 \\
Type of drum & 30 -gallon & 30 -gallon & 30 -gallon \\
Number of drums per pallet & 4 & 4 & 4 \\
Width of pallet, m & 1.0 & 1.0 & 1.0 \\
Required 3-month storage footprint - & 4,100 & 2,200 & 1,200 \\
$\quad$ double tiered pallets, m ${ }^{3}$ & & & \\
UF $_{4}$ content per drum, te & 0.353 & 0.353 & 0.353 \\
Uranium content per drum, te $_{\text {Weight of empty drum, } \mathrm{kg}}$ & 0.276 & 0.276 & 0.276 \\
& 45.4 & 45.4 & 45.4 \\
\hline
\end{tabular}

TABLE 11.1b Annual Input/Output Summary, 55-Gallon Drums

\begin{tabular}{lrrr}
\hline & \multicolumn{3}{c}{ Percentage of Original Inventory } \\
\cline { 2 - 4 } \multicolumn{1}{c}{ Parameter } & $100 \%$ & $50 \%$ & $25 \%$ \\
\hline & & & \\
Received drums of UF 4 per year & 37,450 & 18,750 & 9,400 \\
Type of drum & 55 -gallon & 55 -gallon & 55 -gallon \\
Number of drums per pallet & 4 & 4 & 4 \\
Width of pallet, m & 1.22 & 1.22 & 1.22 \\
Required 3-month storage footprint - & 3,100 & 1,600 & 1,000 \\
$\quad$ double tiered pallets, m ${ }^{3}$ & & & \\
UF & 0.644 & 0.644 & 0.644 \\
Uranium content per drum, te $_{\text {Weight of empty drum, } \mathrm{kg}}$ & 0.504 & 0.504 & 0.504 \\
& 34.0 & 34.0 & 34.0 \\
\hline
\end{tabular}


TABLE 11.2a Land Use Requirements for Wasteform Facility, 30-Gallon Drums

\begin{tabular}{lcrr}
\hline & \multicolumn{3}{c}{ Percentage of Original Inventory } \\
\cline { 2 - 4 } & & & \\
\multicolumn{1}{c}{ Parameter } & $100 \%$ & $50 \%$ & $25 \%$ \\
\hline & 1.7 & 1.1 & 0.8 \\
Construction area, ha & 168 & 136 & 115 \\
Length, m & 99 & 80 & 68 \\
Width, m & 1.7 & 1.1 & 0.8 \\
Plant site area, ha & 168 & 136 & 115 \\
Length, m & 99 & 80 & 68 \\
Width, m & 0.33 & 0.24 & 0.19 \\
Total paved area, ha & 1.6 & 1.0 & 0.7 \\
Total fenced area, ha & 675 & 675 & 675 \\
Administrative building footprint area, $\mathrm{m}^{2}$ & 4,100 & 2,200 & 1,200 \\
Product receiving and shipping warehouse & & & \\
footprint area, ${ }^{2}$ & 9,550 & 5,750 & 3,750 \\
Total excavated material, $\mathrm{m}^{3}$ & &
\end{tabular}

TABLE 11.2b Land Use Requirements for Wasteform Facility, 55-Gallon Drums

\begin{tabular}{lccc}
\hline & \multicolumn{3}{c}{ Percentage of Original Inventory } \\
\cline { 2 - 4 } \multicolumn{1}{c}{ Parameter } & $100 \%$ & $50 \%$ & $25 \%$ \\
\hline & & & \\
Construction area, ha & 1.4 & 0.9 & 0.7 \\
Length, m & 152 & 124 & 111 \\
Width, m & 89 & 73 & 65 \\
Plant site area, ha & 1.4 & 0.9 & 0.7 \\
Length, m & 152 & 124 & 111 \\
Width, m & 89 & 73 & 65 \\
Total paved area, ha & 0.28 & 0.21 & 0.18 \\
Total fenced area, ha & 1.3 & 0.8 & 0.6 \\
Administrative building footprint area, $\mathrm{m}^{2}$ & 675 & 675 & 675 \\
Product receiving and shipping warehouse & 3,100 & 1,600 & 1,000 \\
footprint area, $\mathrm{m}^{2}$ & & & \\
Total excavated material, $\mathrm{m}^{3}$ & 7,550 & 4,550 & 3,350 \\
\hline
\end{tabular}


TABLE 11.3a Land Use Requirements for Mined-Cavity Disposal Area, 30-Gallon Drums

\begin{tabular}{|c|c|c|c|}
\hline \multirow[b]{2}{*}{ Parameter } & \multicolumn{3}{|c|}{ Percentage of Original Inventory } \\
\hline & $100 \%$ & $50 \%$ & $25 \%$ \\
\hline $\begin{array}{l}\text { Construction area aboveground } \\
\text { (including wasteform facility), ha }\end{array}$ & 236 & 105 & 47 \\
\hline $\begin{array}{l}\text { Aboveground plant site area } \\
\text { (including wasteform facility), ha }\end{array}$ & 236 & 105 & 47 \\
\hline Paved area aboveground, ha & 12 & 10 & 9 \\
\hline Waste ramp area, ha & 1.24 & 1.24 & 1.24 \\
\hline Length, $\mathrm{m}$ & 2,065 & 2,065 & 2,065 \\
\hline Diameter, m & 7 & 7 & 7 \\
\hline Height, m & 5 & 5 & 5 \\
\hline Rock ramp area, ha & 1.24 & 1.24 & 1.24 \\
\hline Length, $\mathrm{m}$ & 2,065 & 2,065 & 2,065 \\
\hline Diameter, m & 7 & 7 & 7 \\
\hline Height, $\mathrm{m}$ & 5 & 5 & 5 \\
\hline Perimeter tunnel, ha & 3.78 & 2.70 & 1.94 \\
\hline Length, m & 7,044 & 7,044 & 7,044 \\
\hline Diameter, $\mathrm{m}$ & 7 & 7 & 7 \\
\hline Height, $\mathrm{m}$ & 5 & 5 & 5 \\
\hline Depth of shafts, $m$ & 180 & 180 & 180 \\
\hline Man and material shaft diameter, $\mathrm{m}$ & 6 & 6 & 6 \\
\hline Exhaust shaft \#1 diameter, m & 6 & 6 & 6 \\
\hline Exhaust shaft \#2 diameter, $\mathrm{m}$ & 3 & 3 & 3 \\
\hline Exhaust shaft \#3 diameter, m & 2 & 2 & 2 \\
\hline Mined-cavity underground area, ha & 247 & 127 & 65 \\
\hline Length, $\mathrm{m}$ & 1,586 & 1,124 & 816 \\
\hline Width, m & 1,560 & 1,126 & 800 \\
\hline Central service tunnel area, ha & 1.98 & 1.41 & 1.02 \\
\hline Length, $\mathrm{m}$ & 1,586 & 1,124 & 816 \\
\hline Width, m & 20 & 20 & 20 \\
\hline Height, m & 5 & 5 & 5 \\
\hline Number of mine drifts & 40 & 28 & 20 \\
\hline Total emplacement drift length, $m$ & 30,515 & 15,269 & 7,646 \\
\hline Single drift area, ha & 0.44 & 0.31 & 0.22 \\
\hline Length, $\mathrm{m}$ & 763 & 546 & 383 \\
\hline Width, m & 6.5 & 6.5 & 6.5 \\
\hline Height, $\mathrm{m}$ & 5 & 5 & 5 \\
\hline Spacing between drift tunnels, $\mathrm{m}$ & 32 & 32 & 32 \\
\hline Total paved area underground, ha & 25.8 & 15.4 & 9.8 \\
\hline Total excavated material, $\mathrm{m}^{3}$ & $1.22 \mathrm{E}+06$ & $7.62 \mathrm{E}+05$ & $5.13 \mathrm{E}+05$ \\
\hline
\end{tabular}


TABLE 11.3b Land Use Requirements for Mined-Cavity Disposal Area, 55-Gallon Drums

\begin{tabular}{|c|c|c|c|}
\hline \multirow[b]{2}{*}{ Parameter } & \multicolumn{3}{|c|}{ Percentage of Original Inventory } \\
\hline & $100 \%$ & $50 \%$ & $25 \%$ \\
\hline $\begin{array}{l}\text { Construction area aboveground } \\
\text { (including wasteform facility), ha }\end{array}$ & 168 & 75 & 34 \\
\hline $\begin{array}{l}\text { Aboveground plant site area } \\
\text { (including wasteform facility), ha }\end{array}$ & 168 & 75 & 34 \\
\hline Paved area aboveground, ha & 11 & 10 & 9 \\
\hline Waste ramp area, ha & 1.24 & 1.24 & 1.24 \\
\hline Length, $\mathrm{m}$ & 2,065 & 2,065 & 2,065 \\
\hline Width, m & 7 & 7 & 7 \\
\hline Height, m & 5 & 5 & 5 \\
\hline Rock ramp area, ha & 1.24 & 1.24 & 1.24 \\
\hline Length, $\mathrm{m}$ & 2,065 & 2,065 & 2,065 \\
\hline Width, m & 7 & 7 & 7 \\
\hline Height, m & 5 & 5 & 5 \\
\hline Perimeter tunnel, ha & 3.28 & 2.35 & 1.69 \\
\hline Length, m & 5,466 & 3,916 & 2,821 \\
\hline Width, m & 7 & 7 & 7 \\
\hline Height, $\mathrm{m}$ & 5 & 5 & 5 \\
\hline Depth of shafts, $m$ & 180 & 180 & 180 \\
\hline Man and material shaft diameter, $\mathrm{m}$ & 6 & 6 & 6 \\
\hline Exhaust shaft \#1 diameter, $\mathrm{m}$ & 6 & 6 & 6 \\
\hline Exhaust shaft \#2 diameter, $\mathrm{m}$ & 3 & 3 & 3 \\
\hline Exhaust shaft \#3 diameter, m & 2 & 2 & 2 \\
\hline Mined-cavity underground area, ha & 187 & 96 & 50 \\
\hline Length, $\mathrm{m}$ & 1,355 & 970 & 701 \\
\hline Width, m & 1,378 & 988 & 710 \\
\hline Central service tunnel area, ha & 1.69 & 1.21 & 0.88 \\
\hline Length, $\mathrm{m}$ & 1,355 & 970 & 701 \\
\hline Width, m & 20 & 20 & 20 \\
\hline Height, m & 5 & 5 & 5 \\
\hline Number of mine drifts & 34 & 24 & 17 \\
\hline Total emplacement drift length, $m$ & 22,830 & 11,415 & 5,731 \\
\hline Single drift area, ha & 0.39 & 0.27 & 0.19 \\
\hline Length, $m$ & 672 & 477 & 338 \\
\hline Width, m & 6.5 & 6.5 & 6.5 \\
\hline Height, $\mathrm{m}$ & 5 & 5 & 5 \\
\hline Spacing between drift tunnels, m & 32 & 32 & 32 \\
\hline Total paved area underground, ha & 20.6 & 12.6 & 8.4 \\
\hline Total excavated material, $\mathrm{m}^{3}$ & $9.91 \mathrm{E}+05$ & $6.39 \mathrm{E}+05$ & $4.44 \mathrm{E}+05$ \\
\hline
\end{tabular}


TABLE 11.4a Construction Resources, 30-Gallon Drums

\begin{tabular}{|c|c|c|c|}
\hline \multirow[b]{2}{*}{ Resource } & \multicolumn{3}{|c|}{ Percentage of Original Inventory } \\
\hline & $100 \%$ & $50 \%$ & $25 \%$ \\
\hline \multicolumn{4}{|l|}{ Wasteform Facility } \\
\hline Water, ML & 3.3 & 2.2 & 1.6 \\
\hline Concrete, redi-mix, $\mathrm{m}^{3}$ & 5,591 & 3,149 & 1,941 \\
\hline Steel, te & 349 & 200 & 122 \\
\hline Excavated material, $\mathrm{m}^{3}$ & 9,550 & 5,750 & 3,750 \\
\hline Electricity, MW-h & 480 & 346 & 276 \\
\hline Masonry brick, $\mathrm{m}^{2}$ & 573 & 573 & 573 \\
\hline Diesel fuel, L & 99,000 & 52,000 & 32,000 \\
\hline \multicolumn{4}{|c|}{ Mined-Cavity Disposal Area } \\
\hline Water, ML & 16.7 & 11.1 & 7.9 \\
\hline Concrete, redi-mix, $\mathrm{m}^{3}$ & $9.90 \mathrm{E}+04$ & $6.50 \mathrm{E}+04$ & $4.50 \mathrm{E}+04$ \\
\hline Steel, te & 3,890 & 2,540 & 1,770 \\
\hline Electricity, GW-h & 5,760 & 3,820 & 2,710 \\
\hline Diesel fuel, L & $7.16 \mathrm{E}+05$ & $4.48 \mathrm{E}+05$ & $3.02 \mathrm{E}+05$ \\
\hline Excavated material, $\mathrm{m}^{3}$ & $1.22 \mathrm{E}+06$ & $7.62 \mathrm{E}+05$ & $5.13 \mathrm{E}+05$ \\
\hline
\end{tabular}

TABLE 11.4b Construction Resources, 55-Gallon Drums

\begin{tabular}{|c|c|c|c|}
\hline \multirow[b]{2}{*}{ Resource } & \multicolumn{3}{|c|}{ Percentage of Original Inventory } \\
\hline & $100 \%$ & $50 \%$ & $25 \%$ \\
\hline \multicolumn{4}{|l|}{ Wasteform Facility } \\
\hline Water, ML & 2.7 & 1.8 & 1.5 \\
\hline Concrete, redi-mix, $\mathrm{m}^{3}$ & 4,286 & 2,416 & 1,708 \\
\hline Steel, te & 271 & 153 & 106 \\
\hline Excavated material, $\mathrm{m}^{3}$ & 7,550 & 4,550 & 3,350 \\
\hline Electricity, MW-h & 410 & 304 & 262 \\
\hline Masonry brick, $\mathrm{m}^{2}$ & 573 & 573 & 573 \\
\hline Diesel Fuel, L & 70,000 & 40,000 & 28,000 \\
\hline \multicolumn{4}{|c|}{ Mined-Cavity Disposal Area } \\
\hline Water, ML & 14.0 & 9.5 & 6.9 \\
\hline Concrete, redi-mix, $\mathrm{m}^{3}$ & $8.20 \mathrm{E}+04$ & $5.50 \mathrm{E}+04$ & $3.90 \mathrm{E}+04$ \\
\hline Steel, te & 3,230 & 2,160 & 1,550 \\
\hline Electricity, GW-h & 4,810 & 3,280 & 2,380 \\
\hline Diesel fuel, L & $5.83 \mathrm{E}+05$ & $3.76 \mathrm{E}+05$ & $2.61 \mathrm{E}+05$ \\
\hline Excavated material, $\mathrm{m}^{3}$ & $9.90 \mathrm{E}+05$ & $6.39 \mathrm{E}+05$ & $4.44 \mathrm{E}+05$ \\
\hline
\end{tabular}


TABLE 11.5a Operations Resources, 30-Gallon Drums

\begin{tabular}{lrrr}
\hline & \multicolumn{3}{c}{ Percentage of Original Inventory } \\
\cline { 2 - 4 } \multicolumn{1}{c}{ Resource } & $100 \%$ & $50 \%$ & \multicolumn{1}{c}{$25 \%$} \\
\hline & & & \\
Wasteform Facility & 12 & 8.5 & 6.2 \\
Water, ML & 2,830 & 1,710 & 1,120 \\
Natural gas, therms (1E+05 Btu) & 13,400 & 9,800 & 7,500 \\
Electricity, MW-h & 11,100 & 8,900 & 7,400 \\
Diesel fuel, L & & & \\
& & & \\
Mined-Cavity Disposal Area & $1.66 \mathrm{E}+05$ & $1.18 \mathrm{E}+05$ & $8.32 \mathrm{E}+04$ \\
Water, ML & $1.86 \mathrm{E}+05$ & $1.18 \mathrm{E}+05$ & $7.46 \mathrm{E}+04$ \\
\hline Electricity, GW-h & & & \\
Diesel fuel, L & & & \\
&
\end{tabular}

TABLE 11.5b Operations Resources, 55-Gallon Drums

\begin{tabular}{lrrr}
\hline & \multicolumn{3}{c}{ Percentage of Original Inventory } \\
\cline { 2 - 4 } \multicolumn{1}{c}{ Resource } & $100 \%$ & $50 \%$ & \multicolumn{1}{c}{$25 \%$} \\
\hline & & & \\
Wasteform Facility & 10 & 7.2 & 5.7 \\
Water, ML & 2,240 & 1,350 & 1,000 \\
Natural gas, therms (1E+05 Btu) & 11,600 & 8,400 & 6,900 \\
Electricity, MW-h & 10,000 & 8,100 & 7,100 \\
Diesel fuel, L & \multicolumn{3}{c}{} \\
& 46.5 & 33.6 & 24.3 \\
Mined-Cavity Disposal Area & $1.23 \mathrm{E}+05$ & $8.68 \mathrm{E}+04$ & $6.16 \mathrm{E}+04$ \\
Water, ML & $1.25 \mathrm{E}+05$ & $7.88 \mathrm{E}+04$ & $5.00 \mathrm{E}+04$ \\
\hline Electricity, GW-h & & & \\
Diesel fuel, L & & & \\
&
\end{tabular}

TABLE 11.6a Employment, 30-Gallon Drums

\begin{tabular}{lccr}
\hline & \multicolumn{3}{c}{ Percentage of Original Inventory } \\
\cline { 2 - 4 } \multicolumn{1}{c}{ Stage } & $100 \%$ & $50 \%$ & $25 \%$ \\
\hline & & & \\
Wasteform Facility & 280 & 140 & 82 \\
Construction (total person-years) & 41 & 29 & 21 \\
Operating (annual) & & & \\
& & & \\
Mined-Cavity Disposal Area & 3,800 & 2,900 & 2,200 \\
Construction (total person-years) & 30 & 20 & 14 \\
Operating (annual) & \multicolumn{3}{c}{} \\
\hline
\end{tabular}


TABLE 11.6b Employment, 55-Gallon Drums

\begin{tabular}{lccc}
\hline & & & \\
& \multicolumn{1}{c}{ Percentage of Original Inventory } \\
\cline { 2 - 4 } & $100 \%$ & $50 \%$ & $25 \%$ \\
\hline & & & \\
Wasteform Facility & 200 & 100 & 72 \\
Construction (total person-years) & 35 & 26 & 20 \\
Operating (annual) & \multicolumn{3}{c}{} \\
Mined-Cavity Disposal Area & 3,400 & 2,600 & 2,000 \\
Construction (total person-years) & 25 & 17 & 12 \\
Operating (annual) & \multicolumn{3}{c}{} \\
\hline
\end{tabular}

TABLE 11.7a Construction Emissions and Wastes, Mined-Cavity Disposal Facility, 30-Gallon Drums

\begin{tabular}{|c|c|c|c|}
\hline \multirow[b]{2}{*}{ Material } & \multicolumn{3}{|c|}{ Percentage of Original Inventory } \\
\hline & $100 \%$ & $50 \%$ & $25 \%$ \\
\hline \multicolumn{4}{|l|}{ Emissions } \\
\hline $\mathrm{CO}$, te $/ \mathrm{yr}$ & 1.51 & 0.945 & 0.637 \\
\hline $\mathrm{NMHC}$, te/yr & 0.530 & 0.332 & 0.224 \\
\hline $\mathrm{NO}_{\mathrm{x}}$, te $/ \mathrm{yr}$ & 7.00 & 4.38 & 2.95 \\
\hline $\mathrm{SO}_{2}$, te $/ \mathrm{yr}$ & 0.462 & 0.289 & 0.195 \\
\hline $\mathrm{PM}_{10}$, te $/ \mathrm{yr}$ & 636 & 282 & 126 \\
\hline Methane, te/yr & 4.34E-02 & $2.72 \mathrm{E}-02$ & $1.83 \mathrm{E}-02$ \\
\hline \multicolumn{4}{|l|}{ Wastes } \\
\hline Hazardous solids, m³ & 200 & 153 & 116 \\
\hline Hazardous liquids, $\mathrm{m}^{3}$ & 406 & 309 & 234 \\
\hline Concrete, $\mathrm{m}^{3}$ & $1.98 \mathrm{E}+03$ & 1,300 & 900 \\
\hline Steel, te & 19.5 & 12.7 & 8.9 \\
\hline Other solid waste, $\mathrm{m}^{3}$ & $1.60 \mathrm{E}+04$ & $1.04 \mathrm{E}+04$ & $7.26 \mathrm{E}+03$ \\
\hline Sanitary liquids, $\mathrm{m}^{3}$ & $5.80 \mathrm{E}+04$ & $4.40 \mathrm{E}+04$ & $3.40 \mathrm{E}+04$ \\
\hline Other liquids, $\mathrm{m}^{3}$ & $2.60 \mathrm{E}+04$ & $2.00 \mathrm{E}+04$ & $1.50 \mathrm{E}+04$ \\
\hline
\end{tabular}


TABLE 11.7b Construction Emissions and Wastes, Mined-Cavity Disposal Facility, 55-Gallon Drums

\begin{tabular}{|c|c|c|c|}
\hline \multirow[b]{2}{*}{ Material } & \multicolumn{3}{|c|}{ Percentage of Original Inventory } \\
\hline & $100 \%$ & $50 \%$ & $25 \%$ \\
\hline \multicolumn{4}{|l|}{ Emissions } \\
\hline $\mathrm{CO}, \mathrm{te} / \mathrm{yr}$ & 1.23 & 0.793 & 0.550 \\
\hline $\mathrm{NMHC}$, te/yr & 0.432 & 0.278 & 0.193 \\
\hline $\mathrm{NO}_{\mathrm{x}}$, te $/ \mathrm{yr}$ & 5.70 & 3.60 & 2.55 \\
\hline $\mathrm{SO}_{2}$, te/yr & 0.38 & 0.242 & 0.168 \\
\hline $\mathrm{PM}_{10}$, te/yr & 452 & 201 & 90.7 \\
\hline Methane, te/yr & $3.53 \mathrm{E}-02$ & $2.28 \mathrm{E}-02$ & $1.58 \mathrm{E}-02$ \\
\hline \multicolumn{4}{|l|}{ Wastes } \\
\hline Hazardous solids, $\mathrm{m}^{3}$ & 179 & 137 & 106 \\
\hline Hazardous liquids, $\mathrm{m}^{3}$ & 363 & 278 & 213 \\
\hline Concrete, $\mathrm{m}^{3}$ & $1.64 \mathrm{E}+03$ & $1.11 \mathrm{E}+03$ & 780 \\
\hline Steel, te & 16.2 & 10.8 & 7.8 \\
\hline Other solid waste, $\mathrm{m}^{3}$ & $1.31 \mathrm{E}+04$ & $8.80 \mathrm{E}+03$ & $6.24 \mathrm{E}+03$ \\
\hline Sanitary liquids, $\mathrm{m}^{3}$ & $5.20 \mathrm{E}+04$ & $4.00 \mathrm{E}+04$ & $3.10 \mathrm{E}+04$ \\
\hline Other liquids, $\mathrm{m}^{3}$ & $2.30 \mathrm{E}+04$ & $1.80 \mathrm{E}+04$ & $1.40 \mathrm{E}+04$ \\
\hline \multicolumn{4}{|c|}{$\begin{array}{l}\text { TABLE 11.8a Construction Emissions and Wastes, Wasteform } \\
\text { Facility, 30-Gallon Drums }\end{array}$} \\
\hline & \multicolumn{3}{|c|}{ Percentage of Original Inventory } \\
\hline Material & $100 \%$ & $50 \%$ & $25 \%$ \\
\hline \multicolumn{4}{|l|}{ Emissions } \\
\hline $\mathrm{CO}$, te/yr & 0.712 & 0.411 & 0.253 \\
\hline NMHC, te/yr & 0.250 & 0.144 & 0.089 \\
\hline $\mathrm{NO}_{\mathrm{x}}$, te $/ \mathrm{yr}$ & 3.30 & 1.91 & 1.17 \\
\hline $\mathrm{SO}_{2}$, te $/ \mathrm{yr}$ & 0.218 & 0.126 & 0.077 \\
\hline $\mathrm{PM}_{10}$, te $/ \mathrm{yr}$ & 17.9 & 11.7 & 8.45 \\
\hline Methane, te/yr & $2.05 \mathrm{E}-02$ & $1.18 \mathrm{E}-02$ & 7.27E-03 \\
\hline \multicolumn{4}{|l|}{ Wastes } \\
\hline Hazardous solids, $\mathrm{m}^{3}$ & 14.8 & 7.40 & 4.30 \\
\hline Hazardous liquids, $\mathrm{m}^{3}$ & 29.9 & 14.9 & 8.8 \\
\hline Concrete, $\mathrm{m}^{3}$ & 110 & 60 & 40 \\
\hline Steel, te & 1.7 & 1.0 & 0.6 \\
\hline Other solid waste, $\mathrm{m}^{3}$ & 890 & 500 & 310 \\
\hline Sanitary liquids, $\mathrm{m}^{3}$ & $4.30 \mathrm{E}+03$ & $2.10 \mathrm{E}+03$ & $1.30 \mathrm{E}+03$ \\
\hline Other liquids, $\mathrm{m}^{3}$ & $1.90 \mathrm{E}+03$ & $9.50 \mathrm{E}+02$ & $5.60 \mathrm{E}+02$ \\
\hline
\end{tabular}


TABLE 11.8b Construction Emissions and Wastes, Wasteform Facility, 55-Gallon Drums

\begin{tabular}{|c|c|c|c|}
\hline \multirow[b]{2}{*}{ Material } & \multicolumn{3}{|c|}{ Percentage of Original Inventory } \\
\hline & $100 \%$ & $50 \%$ & $25 \%$ \\
\hline \multicolumn{4}{|l|}{ Emissions } \\
\hline $\mathrm{CO}$, te $/ \mathrm{yr}$ & 0.554 & 0.316 & 0.221 \\
\hline $\mathrm{NMHC}$, te/yr & 0.194 & 0.111 & 0.078 \\
\hline $\mathrm{NO}_{\mathrm{x}}$, te $/ \mathrm{yr}$ & 2.57 & 1.47 & 1.03 \\
\hline $\mathrm{SO}_{2}$, te $/ \mathrm{yr}$ & 0.169 & 0.097 & 0.068 \\
\hline $\mathrm{PM}_{10}$, te/yr & 14.6 & 9.75 & 7.80 \\
\hline Methane, te/yr & 1.59E-02 & 9.09E-03. & $6.36 \mathrm{E}-03$ \\
\hline \multicolumn{4}{|l|}{ Wastes } \\
\hline Hazardous solids, $\mathrm{m}^{3}$ & 10.6 & 5.30 & 3.80 \\
\hline Hazardous liquids, $\mathrm{m}^{3}$ & 21.3 & 10.7 & 7.70 \\
\hline Concrete, $\mathrm{m}^{3}$ & 90 & 50 & 30 \\
\hline Steel, te & 1.4 & 0.8 & 0.5 \\
\hline Other solid waste, $\mathrm{m}^{3}$ & 690 & 390 & 270 \\
\hline Sanitary liquids, $\mathrm{m}^{3}$ & $3.10 \mathrm{E}+03$ & $1.50 \mathrm{E}+03$ & $1.10 \mathrm{E}+03$ \\
\hline Other liquids, $\mathrm{m}^{3}$ & $1.40 \mathrm{E}+03$ & 68 & 49 \\
\hline
\end{tabular}

TABLE 11.9 Operations Emissions and Wastes, MinedCavity Disposal Facility

\begin{tabular}{|c|c|c|c|}
\hline \multirow[b]{2}{*}{ Material } & \multicolumn{3}{|c|}{ Percentage of Original Inventory } \\
\hline & $100 \%$ & $50 \%$ & $25 \%$ \\
\hline \multicolumn{4}{|l|}{ For 30-Gallon Drums } \\
\hline $\mathrm{SO}_{2}$, te $/ \mathrm{yr}$ & $4.5 \mathrm{E}-02$ & $2.8 \mathrm{E}-02$ & $1.8 \mathrm{E}-02$ \\
\hline $\mathrm{NO}_{\mathrm{x}}$, te $/ \mathrm{yr}$ & 0.68 & 0.43 & 0.27 \\
\hline Hydrocarbons, te/yr & $5.6 \mathrm{E}-02$ & $3.5 \mathrm{E}-02$ & $2.2 \mathrm{E}-02$ \\
\hline $\mathrm{CO}$, te/yr & 0.15 & $9.2 \mathrm{E}-02$ & $5.8 \mathrm{E}-02$ \\
\hline $\mathrm{PM}_{10}$, te/yr & $4.8 \mathrm{E}-02$ & $3.0 \mathrm{E}-02$ & $1.9 \mathrm{E}-02$ \\
\hline \multicolumn{4}{|l|}{ For 55-Gallon Drums } \\
\hline $\mathrm{SO}_{2}$, te $/ \mathrm{yr}$ & $3.0 \mathrm{E}-02$ & $1.9 \mathrm{E}-02$ & $1.2 \mathrm{E}-02$ \\
\hline $\mathrm{NO}_{\mathrm{x}}$, te $/ \mathrm{yr}$ & 0.46 & 0.29 & 0.18 \\
\hline Hydrocarbons, te/yr & $3.7 \mathrm{E}-02$ & $2.4 \mathrm{E}-02$ & $1.5 \mathrm{E}-02$ \\
\hline $\mathrm{CO}, \mathrm{te} / \mathrm{yr}$ & $9.7 \mathrm{E}-02$ & $6.2 \mathrm{E}-02$ & $3.9 \mathrm{E}-02$ \\
\hline $\mathrm{PM}_{10}$, te $/ \mathrm{yr}$ & $3.2 \mathrm{E}-02$ & $2.0 \mathrm{E}-02$ & $1.3 \mathrm{E}-02$ \\
\hline
\end{tabular}


TABLE 11.10a Annual Emissions and Wastes, Wasteform Facility, 30-Gallon Drums

\begin{tabular}{|c|c|c|c|}
\hline \multirow[b]{2}{*}{ Material } & \multicolumn{3}{|c|}{ Percentage of Original Inventory } \\
\hline & $100 \%$ & $50 \%$ & $25 \%$ \\
\hline \multicolumn{4}{|l|}{ Emissions } \\
\hline $\mathrm{SO}_{2}$, te/yr & 2.7E-03 & $2.1 \mathrm{E}-03$ & $1.8 \mathrm{E}-03$ \\
\hline $\mathrm{NO}_{\mathrm{x}}$, te $/ \mathrm{yr}$ & 4.1E-02 & $3.3 \mathrm{E}-02$ & 2.7E-02 \\
\hline Hydrocarbons, te/yr & 3.3E-03 & 2.7E-03 & $2.2 \mathrm{E}-03$ \\
\hline $\mathrm{CO}, \mathrm{te} / \mathrm{yr}$ & 8.9E-03 & 7.1E-03 & $5.9 \mathrm{E}-03$ \\
\hline $\mathrm{PM}_{10}$, te/yr & 2.9E-03 & $2.3 \mathrm{E}-03$ & $1.9 \mathrm{E}-03$ \\
\hline \multicolumn{4}{|l|}{ Wastes } \\
\hline Spent HEPA filters, noncombustible, compactable, LLW, $\mathrm{m}^{3}$ & 23.8 & 23.8 & 23.8 \\
\hline Damaged drums, surface contaminated metal LLW, $\mathrm{m}^{3}$ & 7.8 & 3.9 & 2.0 \\
\hline Other LLW, combustible solid LLW, $\mathrm{m}^{3} / \mathrm{yr}$ & 47.6 & 23.8 & 7.9 \\
\hline Inorganic solutions, liquid LLMW, m³/yr & 0.26 & 0.17 & 0.11 \\
\hline Nonhazardous (sanitary) wastes, $\mathrm{m}^{3} / \mathrm{yr}$ & 986 & 701 & 510 \\
\hline Nonhazardous (other) wastes, $\mathrm{m}^{3} / \mathrm{yr}$ & 78 & 55 & 40 \\
\hline Recyclable wastes, $\mathrm{m}^{3} / \mathrm{yr}$ & 31 & 22 & 16 \\
\hline
\end{tabular}

TABLE 11.10b Annual Emissions and Wastes, Wasteform Facility, 55-Gallon Drums

\begin{tabular}{|c|c|c|c|}
\hline \multirow[b]{2}{*}{ Material } & \multicolumn{3}{|c|}{ Percentage of Original Inventory } \\
\hline & $100 \%$ & $50 \%$ & $25 \%$ \\
\hline \multicolumn{4}{|l|}{ Emissions } \\
\hline $\mathrm{SO}_{2}$, te $/ \mathrm{yr}$ & $2.4 \mathrm{E}-03$ & $1.9 \mathrm{E}-03$ & $1.7 \mathrm{E}-03$ \\
\hline $\mathrm{NO}_{\mathrm{x}}$, te $/ \mathrm{yr}$ & 3.7E-02 & $3.0 \mathrm{E}-02$ & 2.6E-02 \\
\hline Hydrocarbons, te/yr & $3.0 \mathrm{E}-03$ & $2.4 \mathrm{E}-03$ & 2.1E-03 \\
\hline $\mathrm{CO}, \mathrm{te} / \mathrm{yr}$ & $8.0 \mathrm{E}-03$ & $6.4 \mathrm{E}-03$ & $5.6 \mathrm{E}-03$ \\
\hline $\mathrm{PM}_{10}$, te/yr & $2.6 \mathrm{E}-03$ & $2.1 \mathrm{E}-03$ & $1.8 \mathrm{E}-03$ \\
\hline \multicolumn{4}{|l|}{ Wastes } \\
\hline Spent HEPA filters, noncombustible, compactable, LLW, $\mathrm{m}^{3}$ & 23.8 & 23.8 & 23.8 \\
\hline Damaged drums, surface contaminated metal LLW, $\mathrm{m}^{3}$ & 7.8 & 3.9 & 2.0 \\
\hline Other LLW, combustible solid LLW, $\mathrm{m}^{3} / \mathrm{yr}$ & 26.2 & 9.6 & 1.6 \\
\hline Inorganic solutions, liquid LLMW, $\mathrm{m}^{3} / \mathrm{yr}$ & 0.18 & 0.12 & 0.08 \\
\hline Nonhazardous (sanitary) wastes, $\mathrm{m}^{3} / \mathrm{yr}$ & 859 & 637 & 478 \\
\hline Nonhazardous (other) wastes, $\mathrm{m}^{3} / \mathrm{yr}$ & 68 & 50 & 38 \\
\hline Recyclable wastes, $\mathrm{m}^{3} / \mathrm{yr}$ & 27 & 20 & 15 \\
\hline
\end{tabular}


TABLE 11.11a Transportation Summary, 30-Gallon Drums

\begin{tabular}{lrrr}
\hline & \multicolumn{3}{c}{ Percentage of Original Inventory } \\
\cline { 2 - 4 } \multicolumn{1}{c}{ Item } & $100 \%$ & $50 \%$ & $25 \%$ \\
\hline & & & \\
Received at Disposal Facility & 17,170 & 8,587 & 4,294 \\
Pallets/yr & 132 & 132 & 132 \\
Pallets/shipment (rail) & 12 & 12 & 12 \\
Pallets/shipment (truck) & 131 & 66 & 33 \\
Shipments/yr (rail) & 1,431 & 716 & 359 \\
Shipments/yr (truck) & & & \\
& 17,170 & 8,587 & 4,294 \\
Internal Site Shipment to Disposal Area & 12 & 12 & 12 \\
Pallets/yr & 1,431 & 716 & 359 \\
Pallets/shipment (truck) & & & \\
Shipments/yr (truck) & &
\end{tabular}

\section{TABLE 11.11b Transportation Summary, 55-Gallon Drums}

\begin{tabular}{lccr}
\hline & \multicolumn{3}{c}{ Percentage of Original Inventory } \\
\cline { 2 - 4 } \multicolumn{1}{c}{ Item } & $100 \%$ & $50 \%$ & $25 \%$ \\
\hline & & & \\
Received at Disposal Facility & 9,362 & 4,687 & 2,344 \\
$\quad$ Pallets/yr & 76 & 76 & 76 \\
Pallets/shipment (rail) & 7 & 7 & 7 \\
Pallets/shipment (truck) & 124 & 62 & 31 \\
Shipments/yr (rail) & 1,338 & 670 & 336 \\
Shipments/yr (truck) & & & \\
& & & \\
Internal Site Shipment to Disposal Area & 9,362 & 4,687 & 2,344 \\
Pallets/yr & 7 & 7 & 7 \\
Pallets/shipment (truck) & 1,338 & 670 & 336 \\
Shipments/yr (truck) & &
\end{tabular}


TABLE 11.12a Number of Construction Workers (FTEs) Needed by Year for Mined-Cavity Disposal Facility, 100\% Case

\begin{tabular}{|c|c|c|c|c|c|c|c|c|c|}
\hline Employees & Year 1 & Year 2 & Year 3 & Year 4 & Year 5 & Year 6 & Year 7 & Year 8 & Total \\
\hline \multicolumn{10}{|c|}{ For 30-Gallon Drums } \\
\hline Total craft workers & 111 & 287 & 456 & 583 & 697 & 697 & 473 & 171 & 3,474 \\
\hline $\begin{array}{l}\text { Construction } \\
\text { management and } \\
\text { support staff }\end{array}$ & 16 & 33 & 51 & 51 & 63 & 63 & 33 & 16 & 326 \\
\hline Subtotal & 127 & 320 & 507 & 633 & 760 & 760 & 507 & 187 & 3,800 \\
\hline \multicolumn{10}{|c|}{ For 55-Gallon Drums } \\
\hline Total craft workers & 99 & 256 & 408 & 521 & 623 & 623 & 424 & 153 & 3,109 \\
\hline $\begin{array}{l}\text { Construction } \\
\text { management and } \\
\text { support staff }\end{array}$ & 14 & 30 & 45 & 45 & 57 & 57 & 30 & 14 & 291 \\
\hline Subtotal & 113 & 286 & 453 & 567 & 680 & 680 & 453 & 167 & 3,400 \\
\hline
\end{tabular}

TABLE 11.12b Number of Construction Workers (FTEs) Needed by Year for Mined-Cavity Disposal Facility, 50\% Case

\begin{tabular}{|c|c|c|c|c|c|c|c|c|c|}
\hline Employees & Year 1 & Year 2 & Year 3 & Year 4 & Year 5 & Year 6 & Year 7 & Year 8 & Total \\
\hline \multicolumn{10}{|c|}{ For 30-Gallon Drums } \\
\hline Total craft workers & 85 & 219 & 348 & 445 & 532 & 532 & 361 & 131 & 2,651 \\
\hline $\begin{array}{l}\text { Construction } \\
\text { management and } \\
\text { support staff }\end{array}$ & 12 & 25 & 39 & 39 & 48 & 48 & 25 & 12 & 249 \\
\hline Subtotal & 97 & 244 & 387 & 483 & 580 & 580 & 387 & 143 & 2,900 \\
\hline \multicolumn{10}{|c|}{ For 55-Gallon Drums } \\
\hline Total craft workers & 76 & 196 & 312 & 399 & 477 & 477 & 324 & 117 & 2,377 \\
\hline $\begin{array}{l}\text { Construction } \\
\text { management and } \\
\text { support staff }\end{array}$ & 11 & 23 & 35 & 35 & 43 & 43 & 23 & 11 & 223 \\
\hline Subtotal & 87 & 219 & 347 & 433 & 520 & 520 & 347 & 128 & 2,600 \\
\hline
\end{tabular}


TABLE 11.12c Number of Construction Workers (FTEs) Needed by Year for Mined-Cavity Disposal Facility, 25\% Case

\begin{tabular}{|c|c|c|c|c|c|c|c|c|c|}
\hline Employees & Year 1 & Year 2 & Year 3 & Year 4 & Year 5 & Year 6 & Year 7 & Year 8 & Total \\
\hline \multicolumn{10}{|c|}{ For 30-Gallon Drums } \\
\hline Total craft workers & 64 & 166 & 264 & 337 & 403 & 403 & 274 & 99 & 2011 \\
\hline $\begin{array}{l}\text { Construction } \\
\text { management and } \\
\text { support staff }\end{array}$ & 9 & 19 & 29 & 29 & 37 & 37 & 19 & 9 & 189 \\
\hline Subtotal & 73 & 185 & 293 & 367 & 440 & 440 & 293 & 108 & 2,200 \\
\hline \multicolumn{10}{|c|}{ For 55-Gallon Drums } \\
\hline Total craft workers & 58 & 151 & 240 & 307 & 367 & 367 & 249 & 90 & 1,829 \\
\hline $\begin{array}{l}\text { Construction } \\
\text { management and } \\
\text { support staff }\end{array}$ & 8 & 17 & 27 & 27 & 33 & 33 & 17 & 8 & 171 \\
\hline Subtotal & 67 & 168 & 267 & 333 & 400 & 400 & 267 & 98 & 2,000 \\
\hline
\end{tabular}

TABLE 11.13a Number of Construction Workers (FTEs) Needed by Year for the Wasteform Facility, 100\% Case

\begin{tabular}{|c|c|c|c|c|c|c|c|c|}
\hline \multirow[b]{2}{*}{ Employees } & \multicolumn{4}{|c|}{ 30-Gallon Disposal Containers } & \multicolumn{4}{|c|}{ 55-Gallon Disposal Containers } \\
\hline & Year 1 & Year 2 & Year 3 & Subtotal & Year 1 & Year 2 & Year 3 & Subtotal \\
\hline Total Craft Workers & 67 & 89 & 89 & 245 & 46 & 62 & 62 & 169 \\
\hline $\begin{array}{l}\text { Construction } \\
\text { management and } \\
\text { support staff }\end{array}$ & 7 & 15 & 22 & 45 & 5 & 10 & 15 & 31 \\
\hline Total & 74 & 104 & 112 & 290 & 51 & 72 & 77 & 200 \\
\hline
\end{tabular}


TABLE 11.13b Number of Construction Workers (FTEs) Needed by Year for the Wasteform Facility, 50\% Case

\begin{tabular}{|c|c|c|c|c|c|c|c|c|}
\hline \multirow[b]{2}{*}{ Employees } & \multicolumn{4}{|c|}{ 30-Gallon Disposal Containers } & \multicolumn{4}{|c|}{ 55-Gallon Disposal Containers } \\
\hline & Year 1 & Year 2 & Year 3 & Subtotal & Year 1 & Year 2 & Year 3 & Subtotal \\
\hline Total craft workers & 32 & 43 & 43 & 118 & 23 & 31 & 31 & 85 \\
\hline $\begin{array}{l}\text { Construction } \\
\text { management and } \\
\text { support staff }\end{array}$ & 4 & 7 & 11 & 22 & 3 & 5 & 8 & 15 \\
\hline Total & 36 & 50 & 54 & 140 & 26 & 36 & 39 & 100 \\
\hline
\end{tabular}

TABLE 11.13c Number of Construction Workers (FTEs) Needed by Year for the Wasteform Facility, 25\% Case

\begin{tabular}{|c|c|c|c|c|c|c|c|c|}
\hline \multirow[b]{2}{*}{ Employees } & \multicolumn{4}{|c|}{ 30-Gallon Disposal Containers } & \multicolumn{4}{|c|}{ 55-Gallon Disposal Containers } \\
\hline & Year 1 & Year 2 & Year 3 & Subtotal & Year 1 & Year 2 & Year 3 & Subtotal \\
\hline Total Craft Workers & 19 & 25 & 25 & 69 & 17 & 22 & 22 & 61 \\
\hline $\begin{array}{l}\text { Construction } \\
\text { management and } \\
\text { support staff }\end{array}$ & 2 & 4 & 6 & 13 & 2 & 4 & 6 & 11 \\
\hline Total & 21 & 29 & 32 & 82 & 18 & 26 & 28 & 72 \\
\hline
\end{tabular}



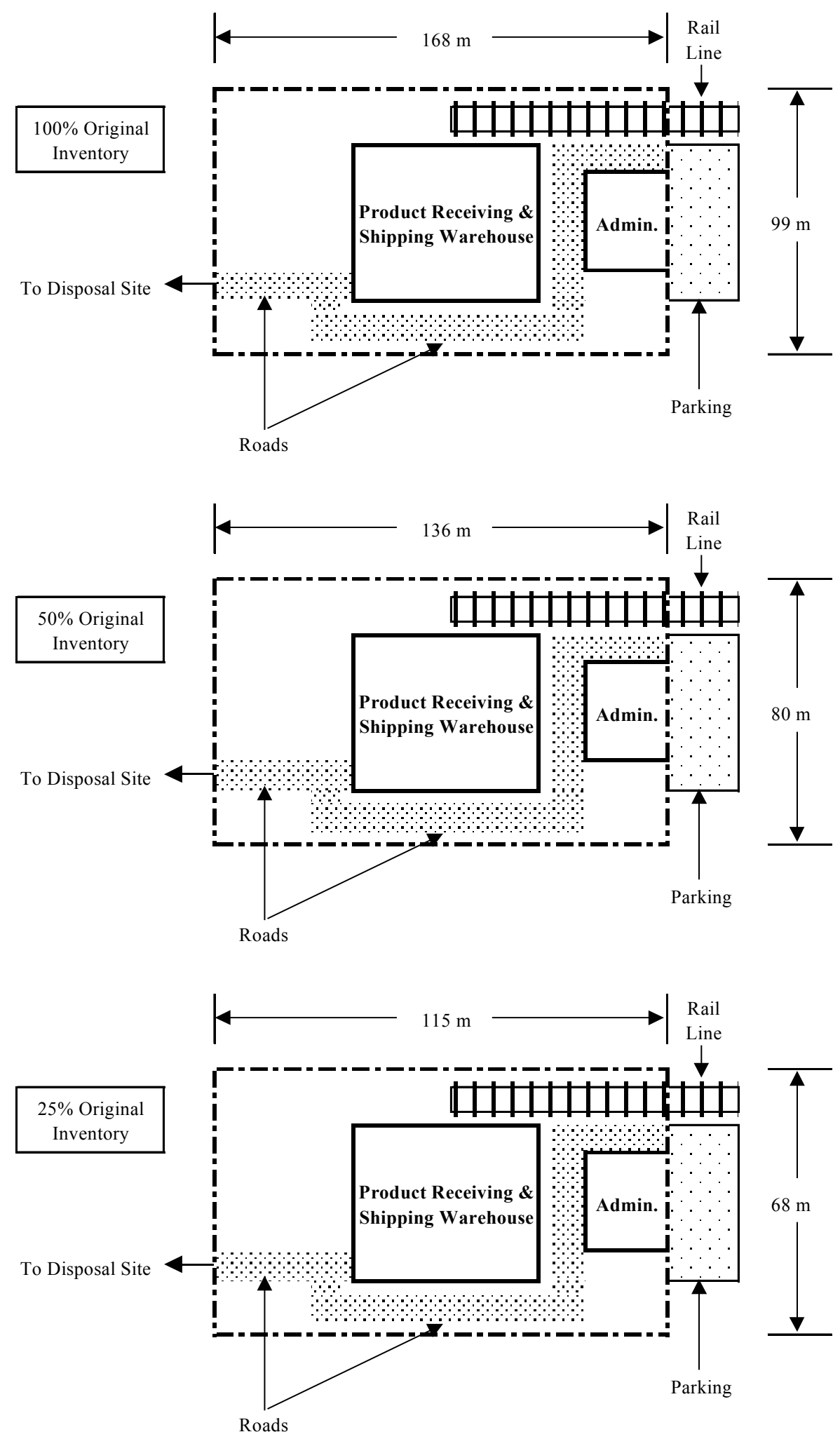

FIGURE 11.1a Wasteform Facility Footprint for 100\%, 50\%, and $25 \%$ of Original Inventory, 30-Gallon Drums (not to scale) 

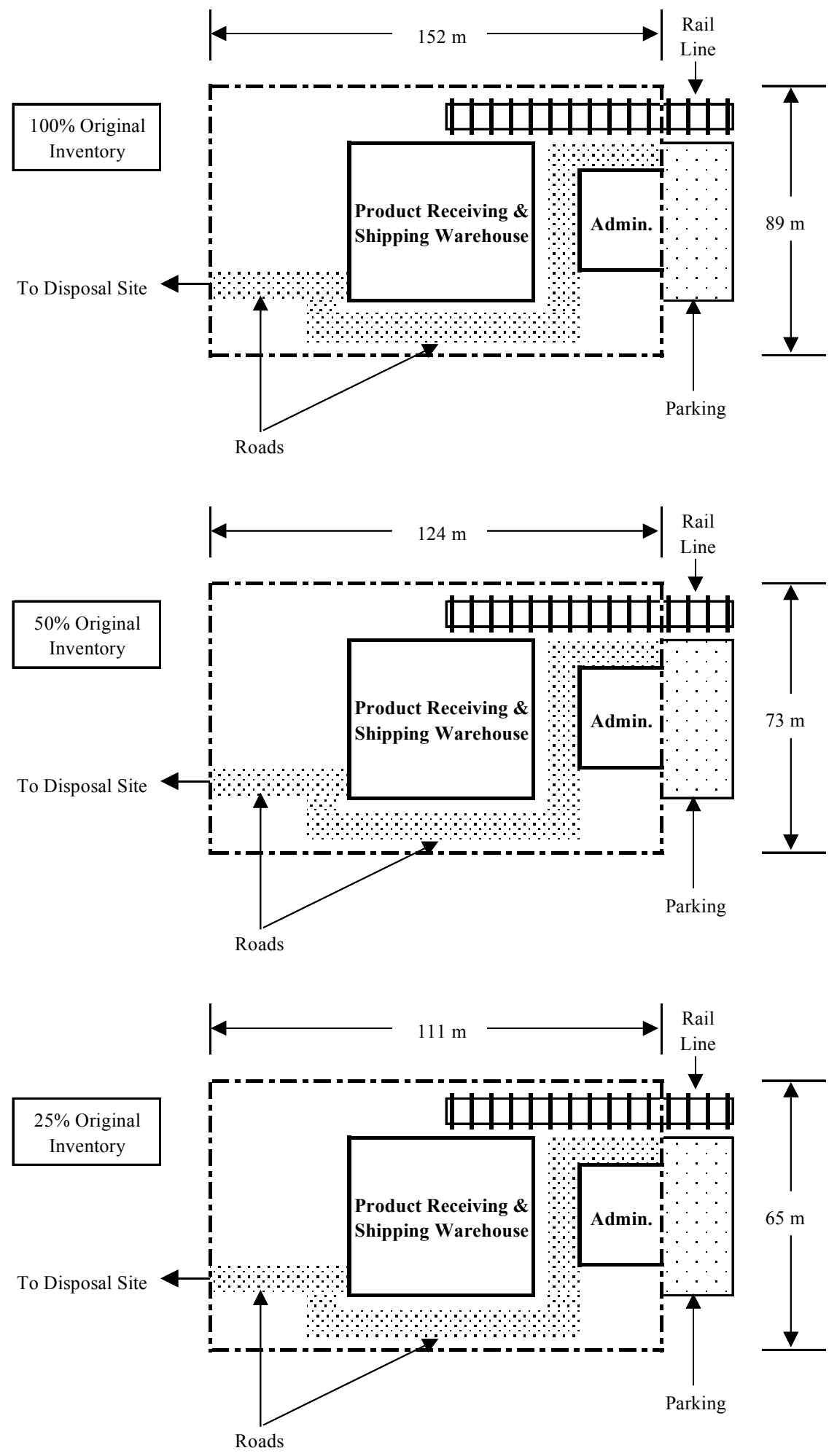

FIGURE 11.1b Wasteform Facility Footprint for $100 \%, 50 \%$, and $25 \%$ of Original Inventory, 55-Gallon Drums (not to scale) 

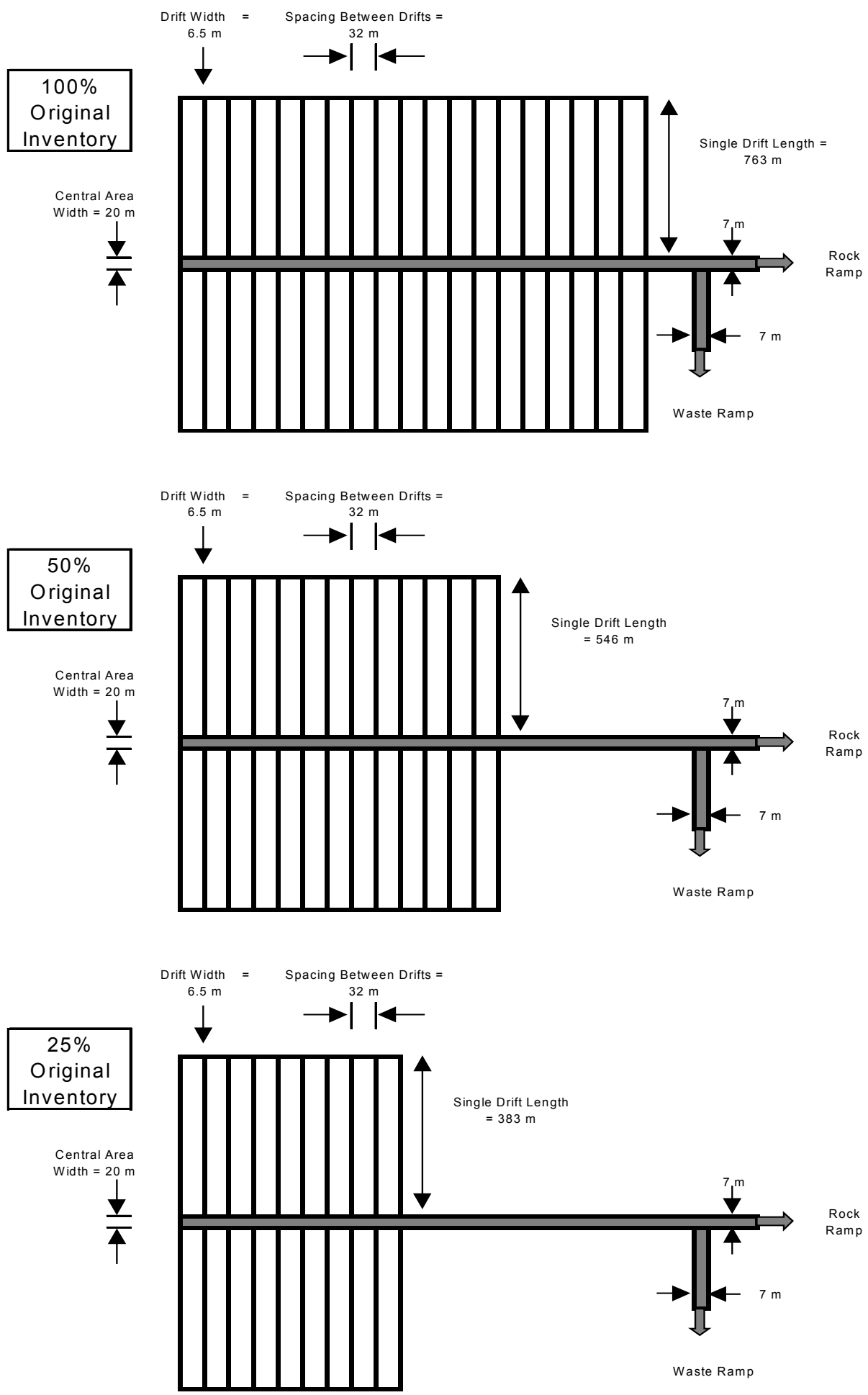

FIGURE 11.2a Mined-Cavity Underground Footprint for $100 \%, 50 \%$, and $25 \%$ of Original Inventory, 30-Gallon Drums (not to scale) 

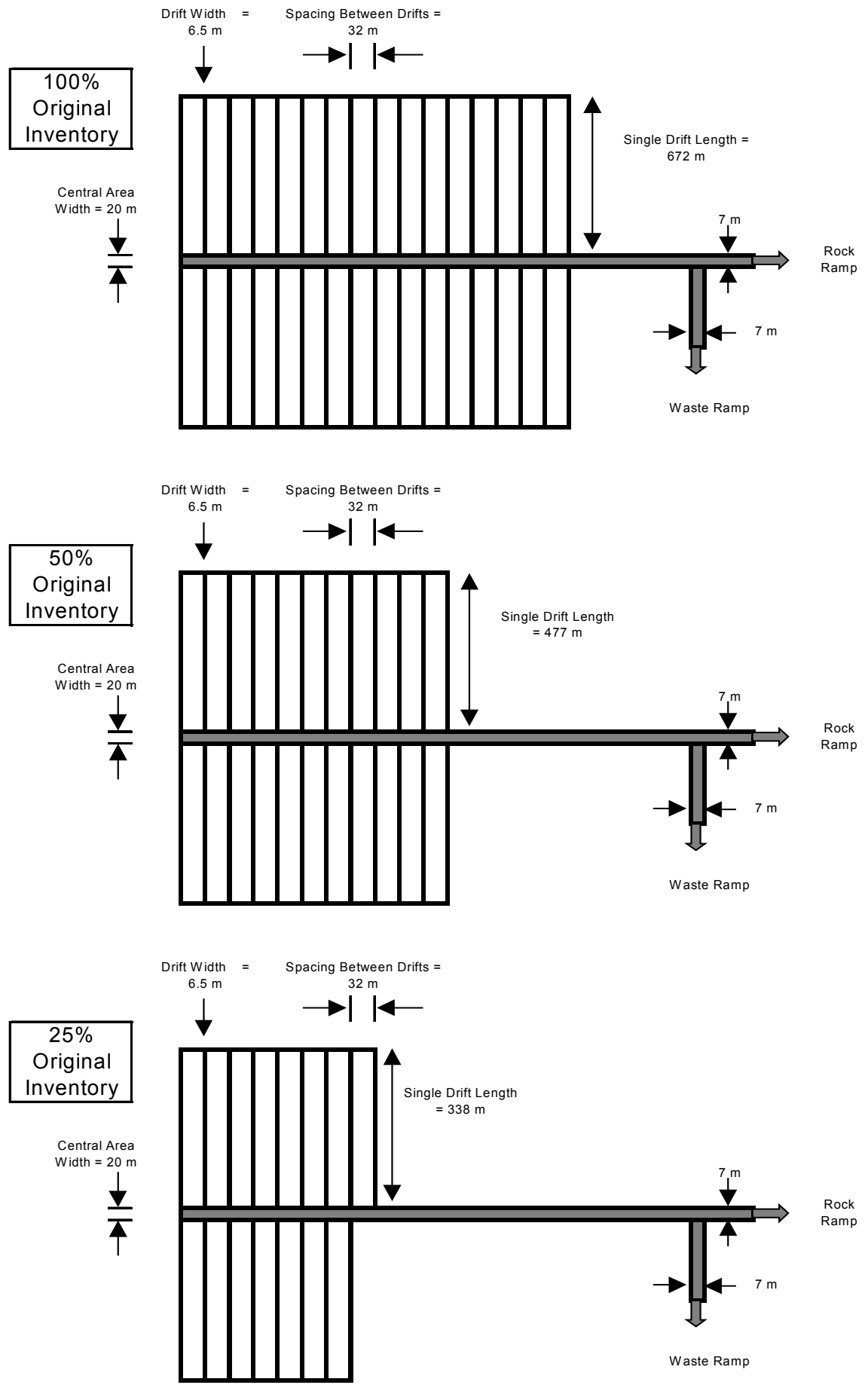

FIGURE 11.2b Mined-Cavity Underground Footprint for $100 \%$, $\mathbf{5 0 \%}$, and $25 \%$ of Original Inventory, 55-Gallon Drums (not to scale) 


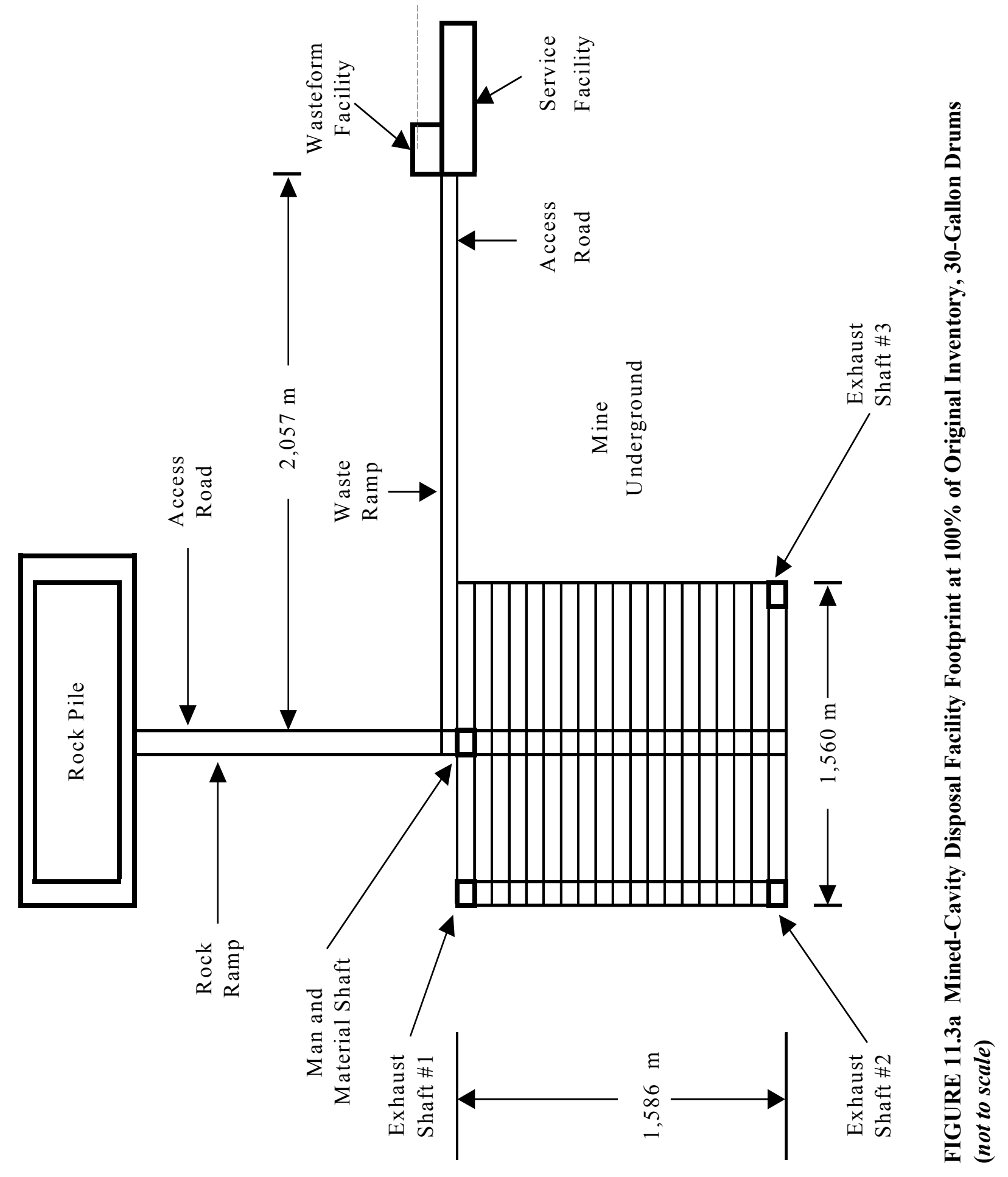




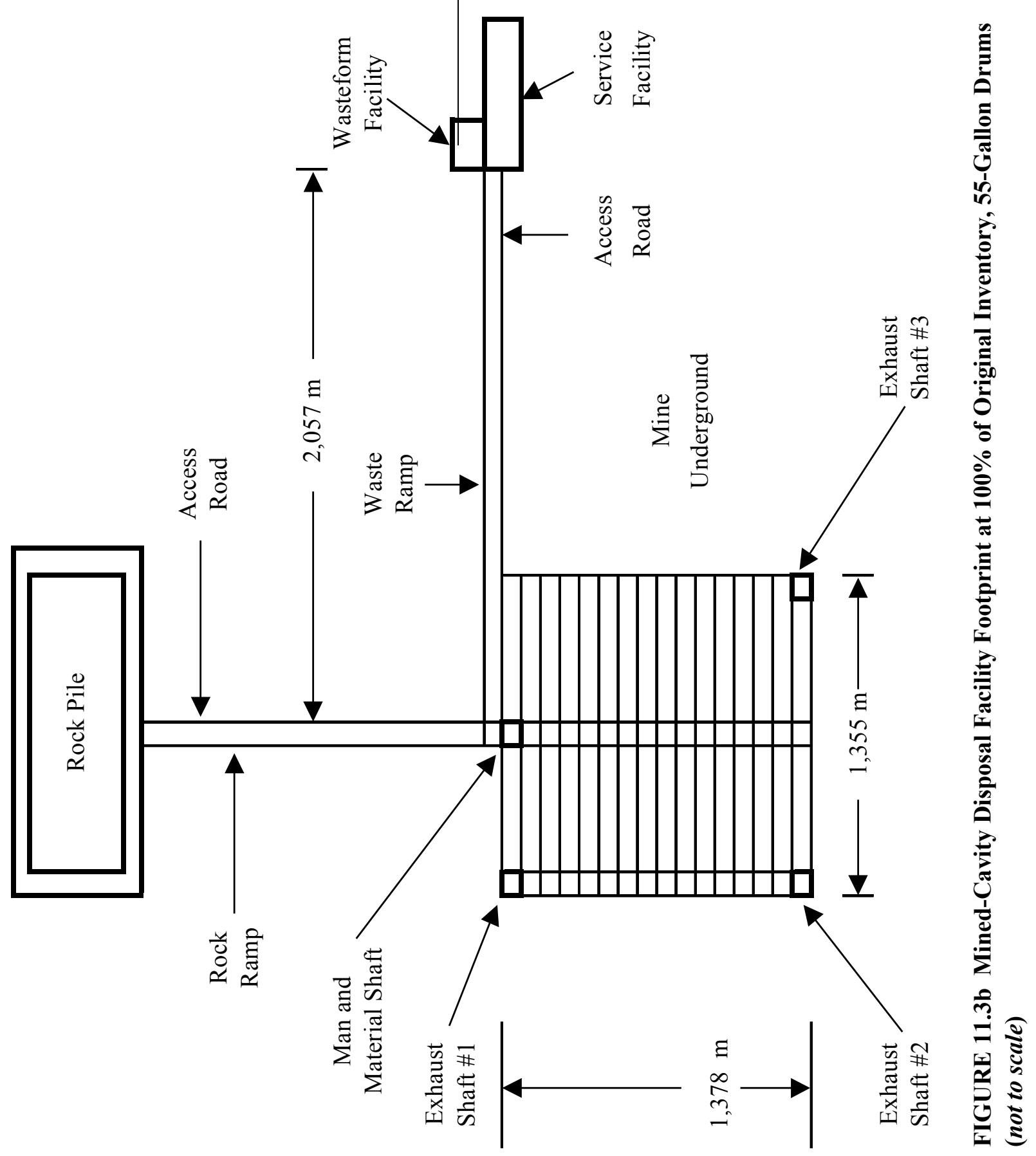




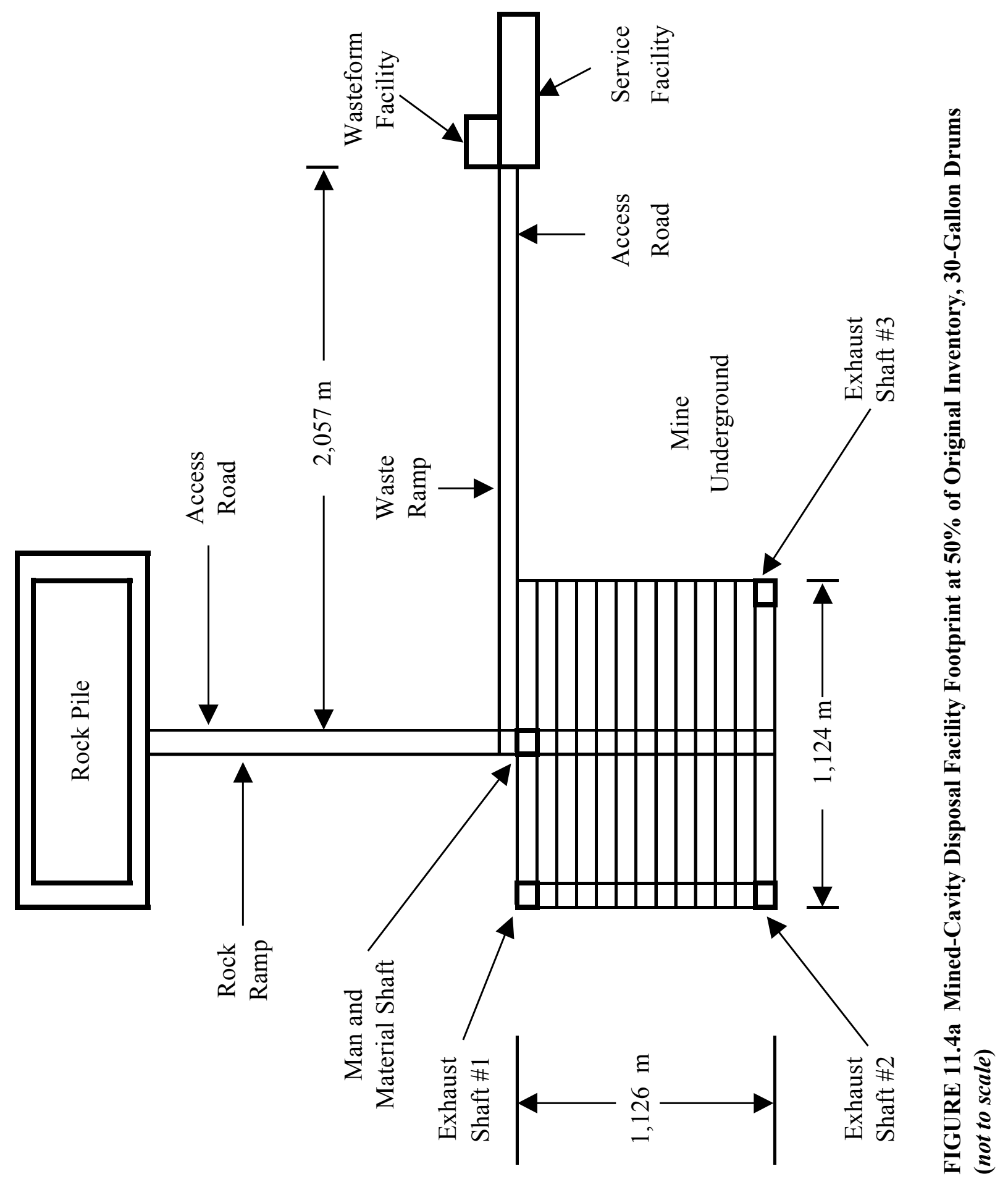




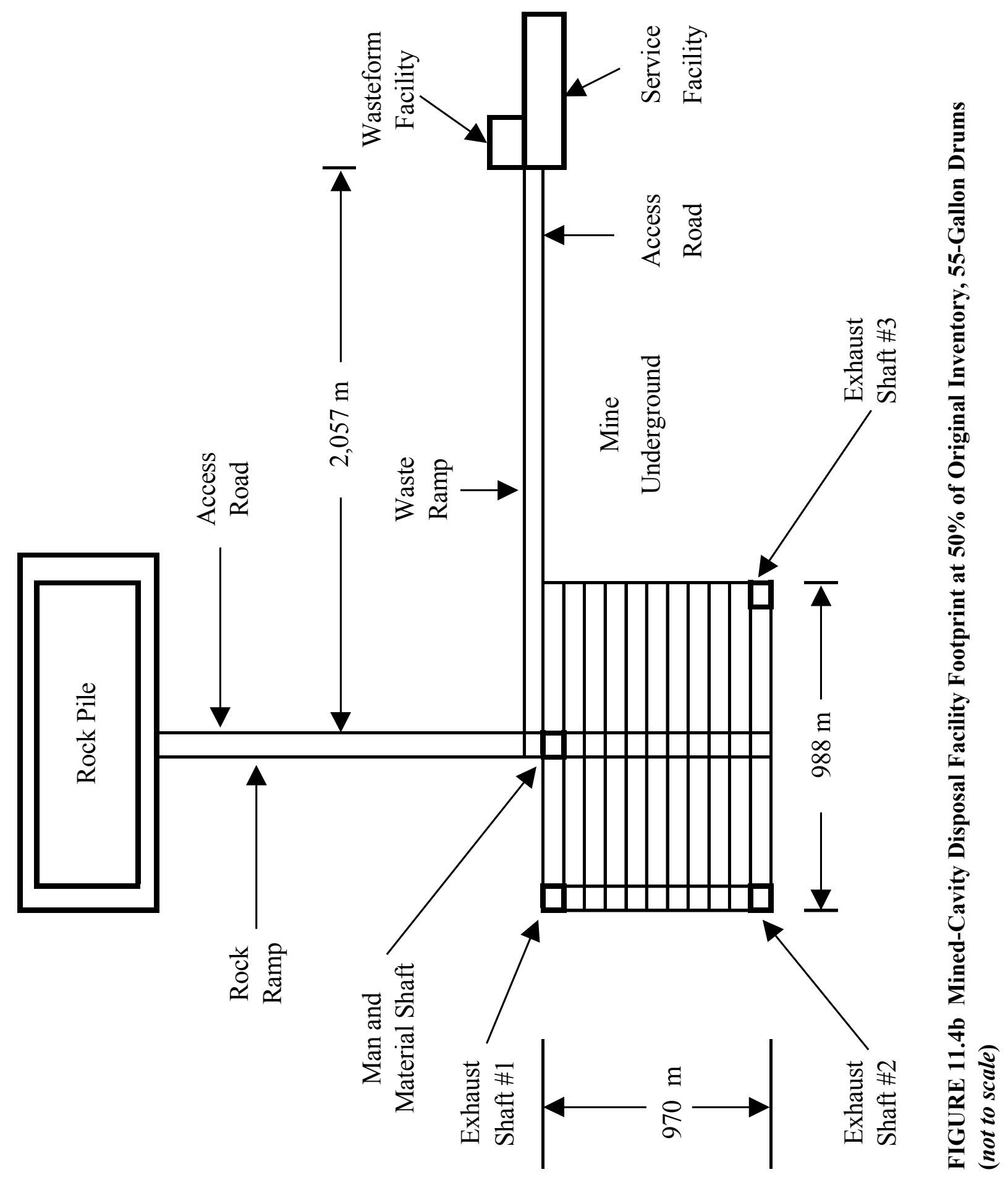




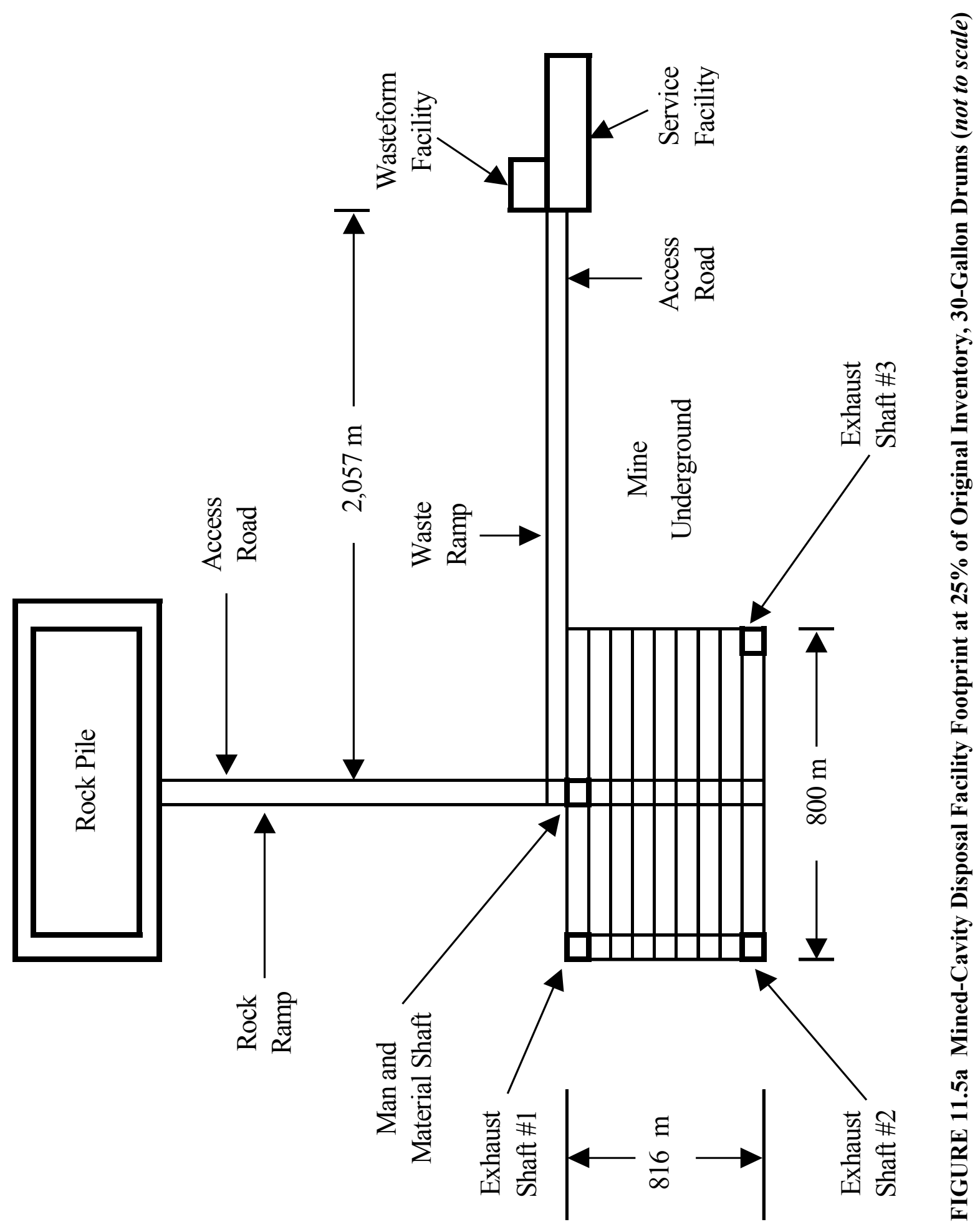




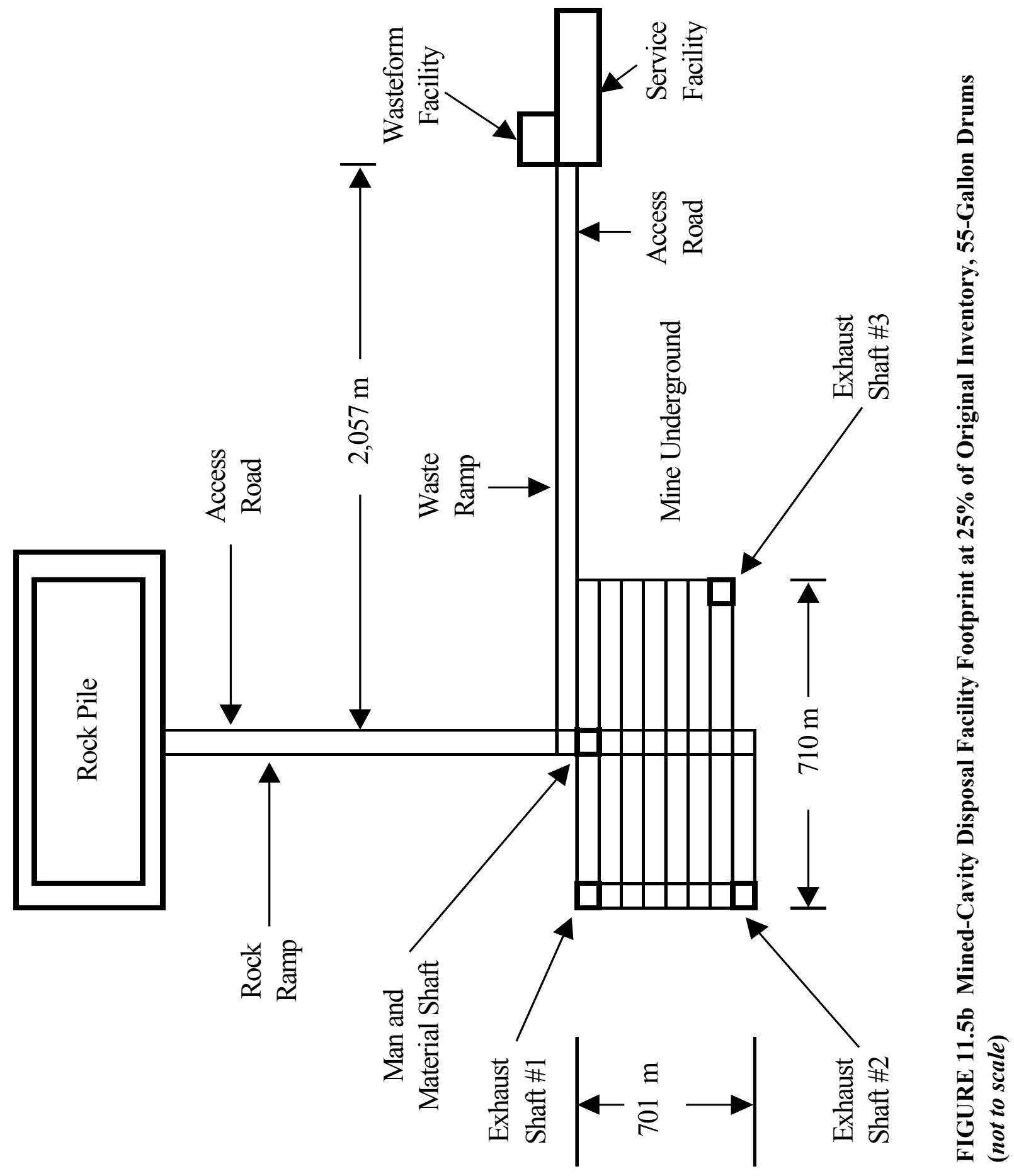




\section{REFERENCES}

Croff, A.G., et al., 2000, Assessment of Preferred Depleted Uranium Disposal Forms, ORNL/TM-2000/161, Oak Ridge National Laboratory, Oak Ridge, Tenn., June.

DOE — See U.S. Department of Energy.

Envirocare of Utah, Inc., 1999, Waste Acceptance Criteria, Clive, Utah, Sept. 30.

EPA — See U.S. Environmental Protection Agency.

Guertaf, R., 2000a, personal communication from Guertaf (Nevada Test Site, HAZMAT Project Manager) to S. Folga (Argonne National Laboratory, Argonne, Ill.), May.

Guertaf, R., 2000b, personal communication from Guetaf (Nevada Test Site, HAZMAT Project Manager) to S. Folga (Argonne National Laboratory, Argonne, Ill.), June 22.

Hightower, J., and J. Trabalka, 2000, Depleted Uranium Storage and Disposal Trade Study: Summary Report, ORNL/TM-2000/10, Oak Ridge National Laboratory, Oak Ridge, Tenn., Feb.

Katz, J.J., et al., 1986, The Chemistry of Actinide Elements, Vol. 2, Second Edition, Chapman and Hall, New York, N.Y.

Lawrence Livermore National Laboratory et al., 1997, Depleted Uranium Management Program; the Engineering Analysis Report for the Long-Term Management of Depleted Uranium Hexafluoride, UCRL-AR-124080, Vols. I and II, prepared by Lawrence Livermore National Laboratory, Science Applications International Corporation, Bechtel, Lockheed Martin Energy Systems, for the U.S. Department of Energy, May.

LLNL — See Lawrence Livermore National Laboratory.

Martin Marietta Energy Systems, 1990, The Ultimate Disposal of Depleted Uranium, K/ETO-44, Oak Ridge, Tenn.

MMES — See Martin Marietta Energy Systems.

NRC - See U.S. Nuclear Regulatory Commission. 
Sattler, J., 2000, personal communication from Sattler (U.S. Department of Energy, Fernald Environmental Management Program, Fernald, Ohio) to S. Folga (Argonne National Laboratory, Argonne, Ill.), April.

U.S. Department of Energy, 1980, Final Environmental Impact Statement, Waste Isolation Pilot Plant, Vol. 1, DOE/EIS-0026, Washington, D.C., Oct.

U.S. Department of Energy, 1994, Natural Phenomena Hazards Design and Evaluation Criteria for Department of Energy Facilities, DOE-STD-1024-94, Washington, D.C., April.

U.S. Department of Energy, 1996, DOE Fire Protection Handbook, DOE-HDBK-1062-96, Washington, D.C.

U.S. Department of Energy, 1997, Fire Protection Design Criteria, DOE Standard DOE-STD1066-97, Washington, D.C.

U.S. Department of Energy, 1999a, Final Programmatic Environmental Impact Statement for Alternative Strategies for the Long-Term Management and Use of Depleted Uranium Hexafluoride, DOE/EIS-0269, Washington, D.C., April.

U.S. Department of Energy, 1999b, Final Plan for the Conversion of Depleted Uranium Hexafluoride, as Required by Public Law 105-204, Office of Nuclear Energy, Science and Technology, Washington, D.C., July.

U.S. Department of Energy, 1999c, Nevada Test Site Waste Acceptance Criteria (NTSWAC), DOE/NV-325, Rev. 2, Nevada Operations Office, Waste Management Division, Las Vegas, Nevada, May.

U.S. Environmental Protection Agency, 1993, Compilation of Air Pollutant Emission Factors, Volume I, Stationary Point and Area Sources, EPA AP-42, Washington, D.C.

U.S. Nuclear Regulatory Commission, 2000, "Licensing Requirements for Land Disposal of Radioactive Waste," Code of Federal Regulations, Title 10, Part 61, Washington, D.C.

Utah Department of Environmental Quality, 2000, Radioactive Material License Number UT 2300249, Amendment 9, Envirocare of Utah, Inc., Licensee, March. 
APPENDIX A:

PRELIMINARY EQUIPMENT LIST 
TABLE A.1 Preliminary Equipment List for the Administration Building

\begin{tabular}{lc}
\hline \multicolumn{1}{c}{ Item/Description } & Number \\
\hline HVAC system & 1 \\
Office PC/LAN system & $30 / 1$ \\
Office furnishing & 30 \\
Conference furnishing & 1 \\
Lunchroom furnishing & 1 \\
Storage shelving system, 1,600 lb-cap per shelf, & 1 \\
$\quad 6$ ft wide $\times 24$ in. deep & \\
Site telephone system & 1 \\
Portal monitor & 1 \\
Transformer & 1 \\
Emergency lighting system & 1 \\
Security door, remote operation & 1 \\
Security gate, remote operation & 1 \\
Area monitoring system, video & 1 \\
\hline
\end{tabular}

TABLE A.2 Preliminary Equipment List for the Product Receiving and Shipping Warehouse

\begin{tabular}{lc}
\hline \multicolumn{1}{c}{ Item/Description } & Number \\
\hline Overhead bridge crane, 15 te & 2 \\
HVAC & 2 \\
HEPA & 2 \\
Dilute acid spray/rinse/drying system & 1 \\
Monitoring station equipment & 1 \\
Decontamination equipment & 2 \\
Office furniture & 1 \\
Personal computers & 2 \\
Deck plate, size to forklift and load & 6 \\
Forklift truck, diesel & 1 \\
Receiving inspection station, complete & 1 \\
Transformer & 1 \\
Emergency lighting system & 1 \\
Prime mover for rail car and semitrailer use & 2 \\
\hline
\end{tabular}


TABLE A.3 Preliminary Equipment List for the Engineered Trench Disposal Facility

\begin{tabular}{lc}
\hline \multicolumn{1}{c}{ Item/Description } & Number \\
\hline & 10 \\
Tractor trailers, drum transport & 4 \\
Emplacement cranes, 10,000-lb capacity & 12 \\
Forklift trucks, 5-te capacity & 4 \\
Vibratory compactor, 4,536-kg capacity & 4 \\
Front-end loaders, 3.5-yd ${ }^{3}$ capacity & 20 \\
Pick up trucks & 40 \\
Sump pumps & 60 \\
Monitoring pipes & 1 \\
0.6-m French drain &
\end{tabular}

TABLE A.4 Preliminary Equipment List for the Vault Disposal Facility

\begin{tabular}{lc}
\hline \multicolumn{1}{c}{ Item/Description } & Number \\
\hline Emplacement cranes, 10,000-lb capacity & 5 \\
Front-end loaders, 3.5-yd ${ }^{3}$ capacity & 5 \\
Pick up trucks & 16 \\
Tractor trailers, drum transport & 5 \\
Forklift trucks, 5-te capacity & 10 \\
Vibratory compactor, 4,536-kg capacity & 5 \\
Sump pump & 76 \\
\hline
\end{tabular}


TABLE A.5 Preliminary Equipment List for the Mined-Cavity Disposal Facility

\begin{tabular}{|c|c|}
\hline Item/Description & Number \\
\hline \multicolumn{2}{|l|}{ Emplacement (Subsurface) Area } \\
\hline Sump pump,2,000 gpm @1,000ft head & 1 \\
\hline Straddle carrier, electric, 10-ton & 6 \\
\hline Radiation monitor station & 4 \\
\hline Emergency power supply & 4 \\
\hline Positive (force) fan, $200,000 \mathrm{cfm}$ & 2 \\
\hline Negative (exhaust) fan, $200,000 \mathrm{cfm}$ & 2 \\
\hline \multicolumn{2}{|l|}{ Surface Support Area } \\
\hline Recovery/service vehicles & 5 \\
\hline Forklift trucks, 5-te & 50 \\
\hline Elevator, 20-ton & 2 \\
\hline Radiation monitor station & 2 \\
\hline Fire sensors/alarm & 1 set \\
\hline Scales & 4 \\
\hline
\end{tabular}


$B-1$

APPENDIX B:

RADIATION EXPOSURE AND MANPOWER DISTRIBUTION ESTIMATING DATA, ORIGINAL AND NEW INVENTORIES 
B-2 


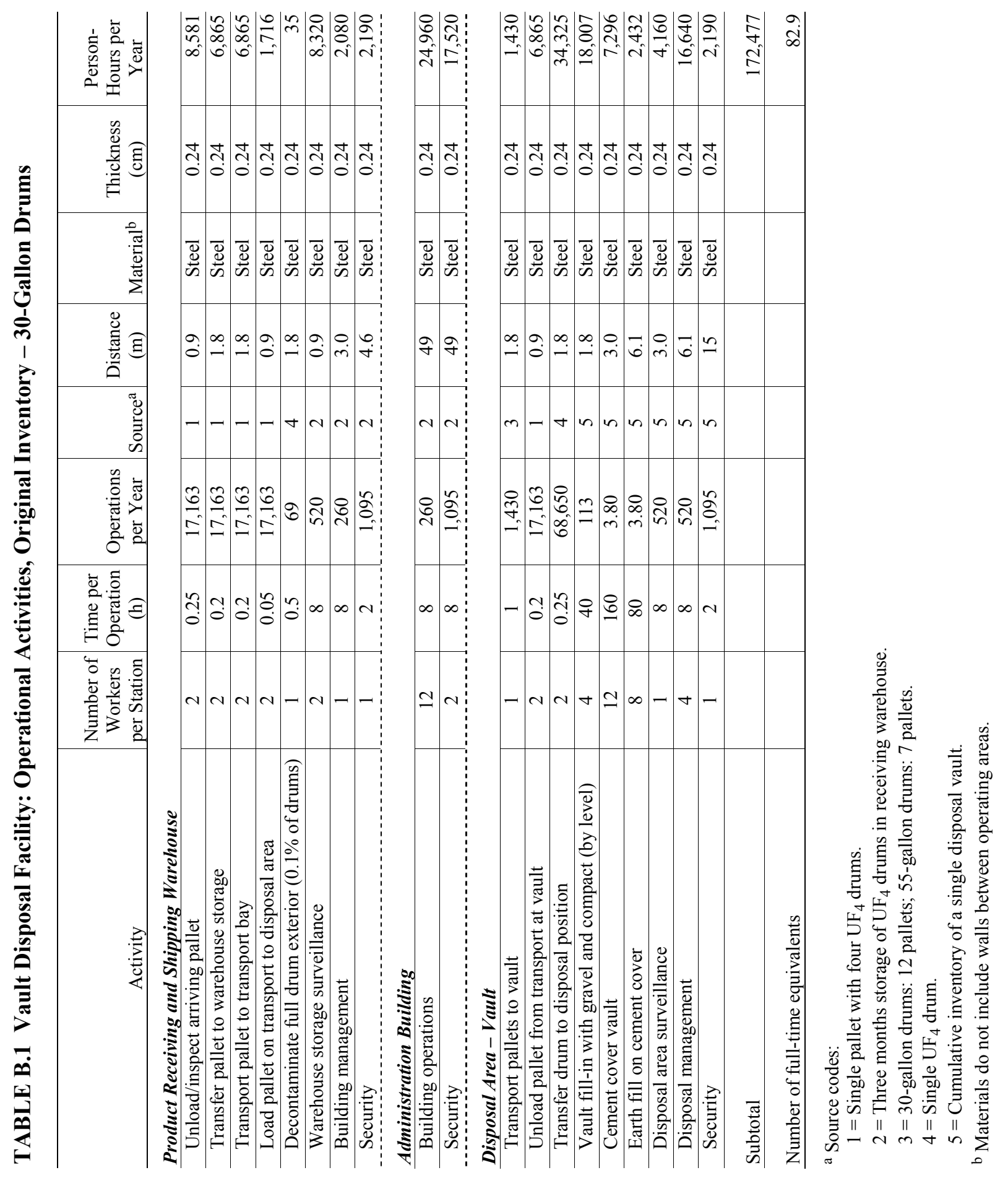




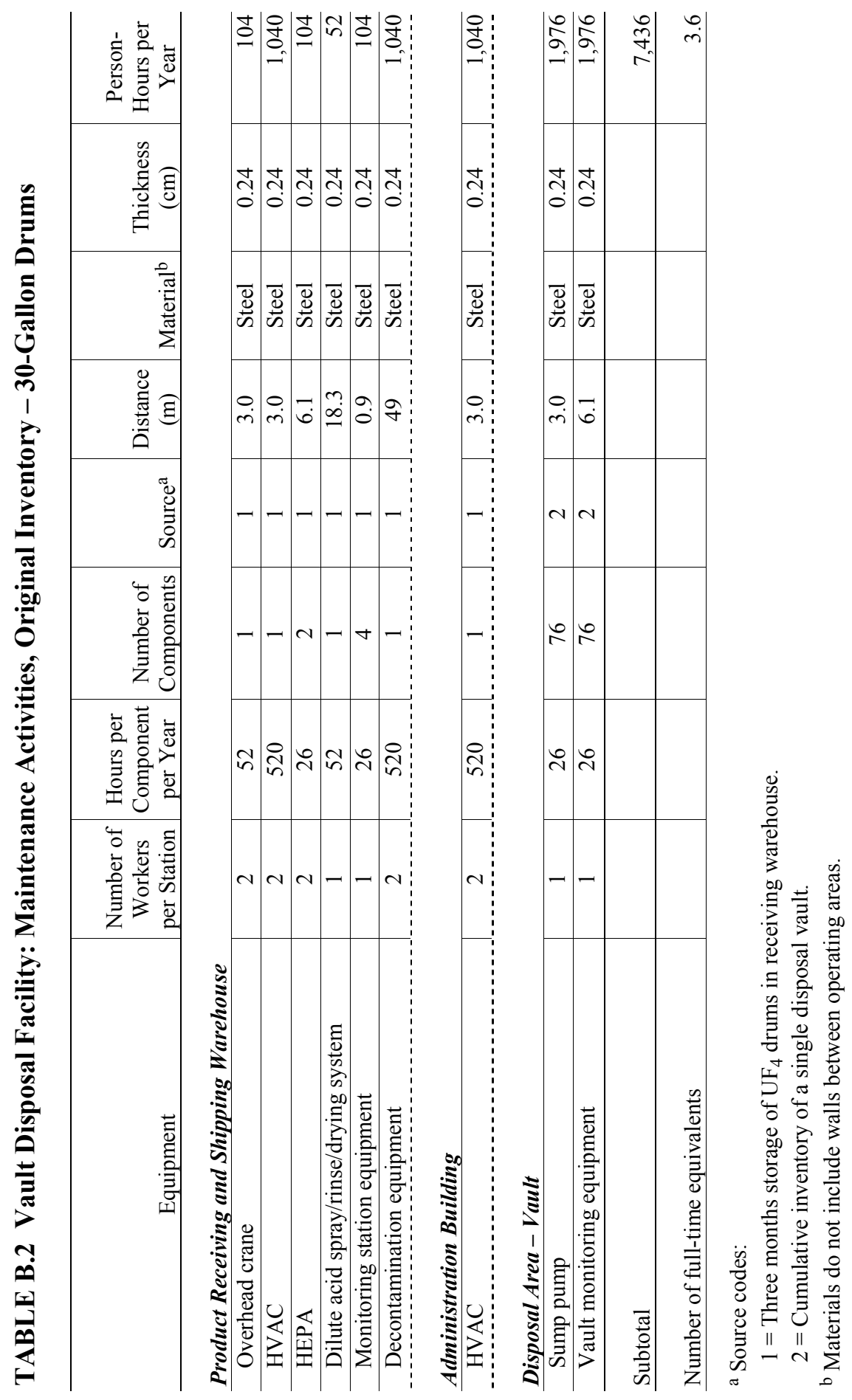




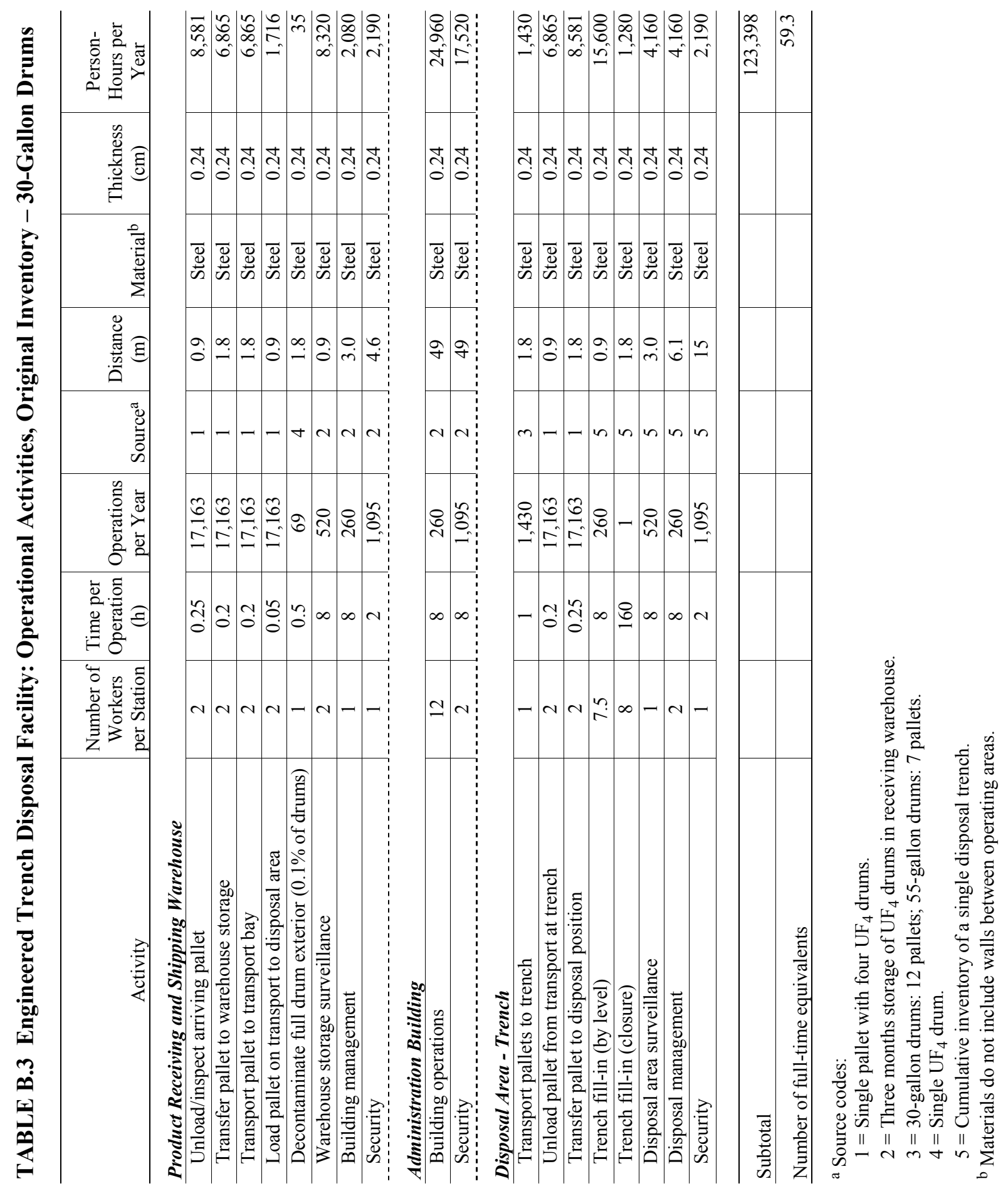




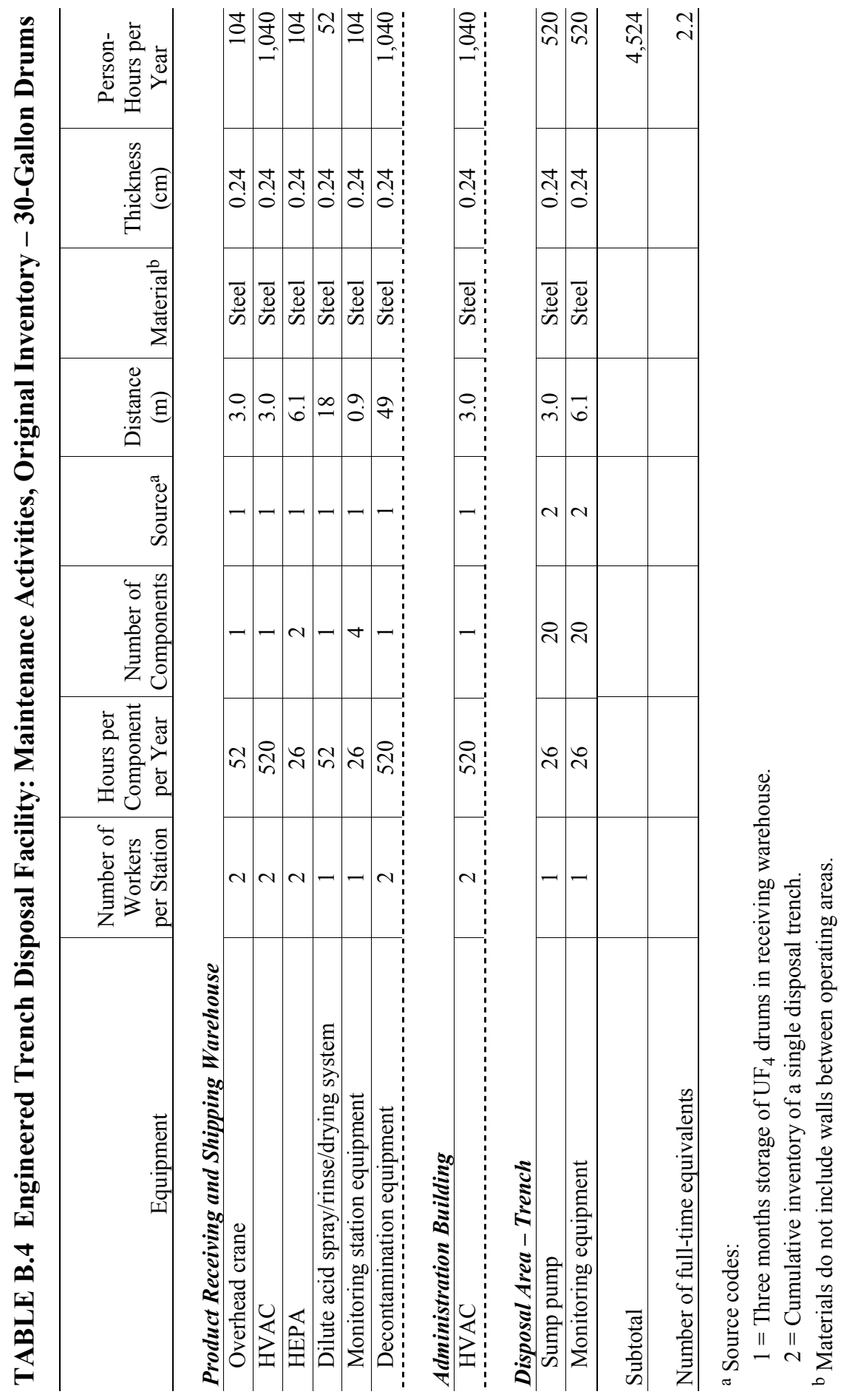




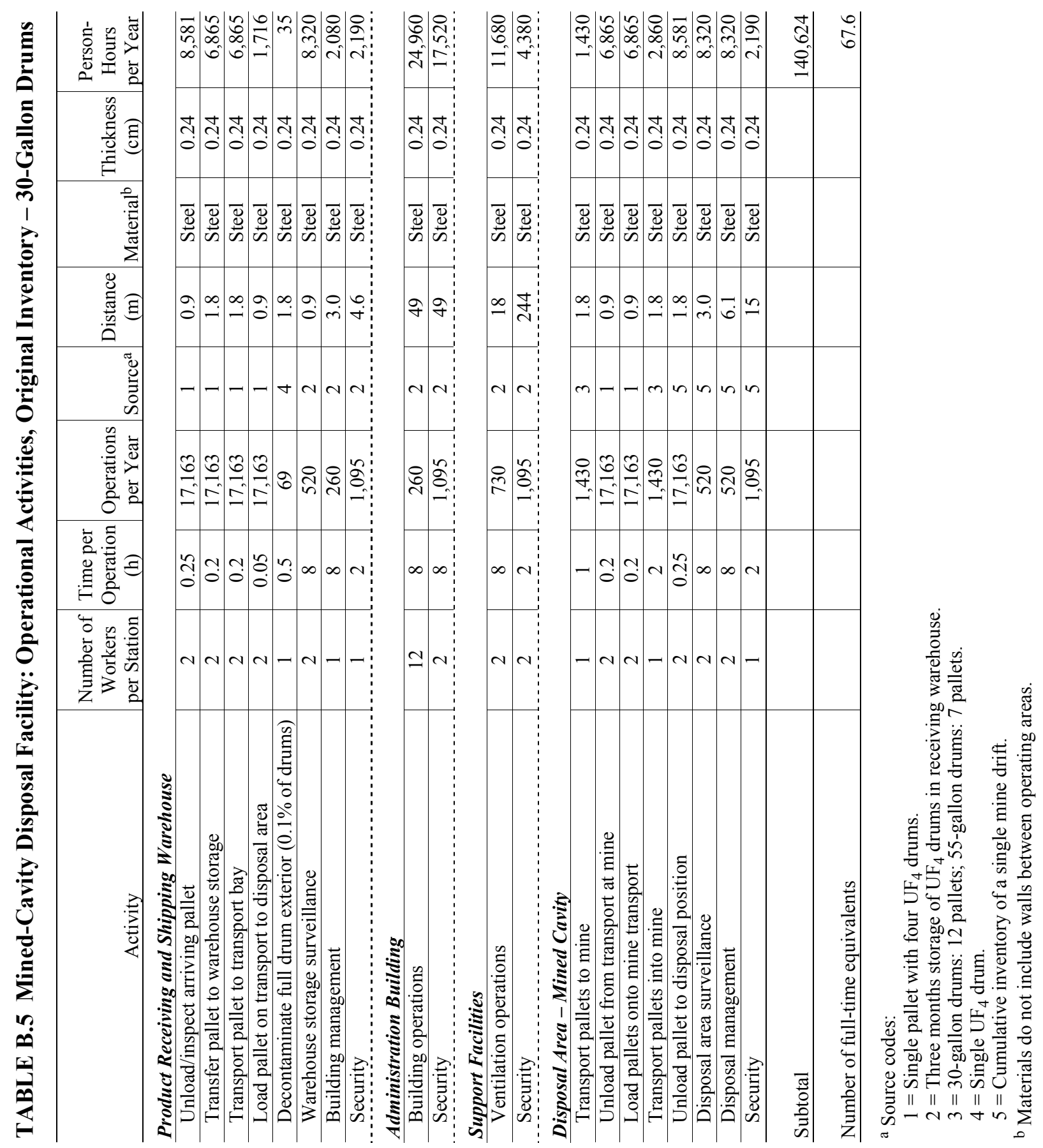




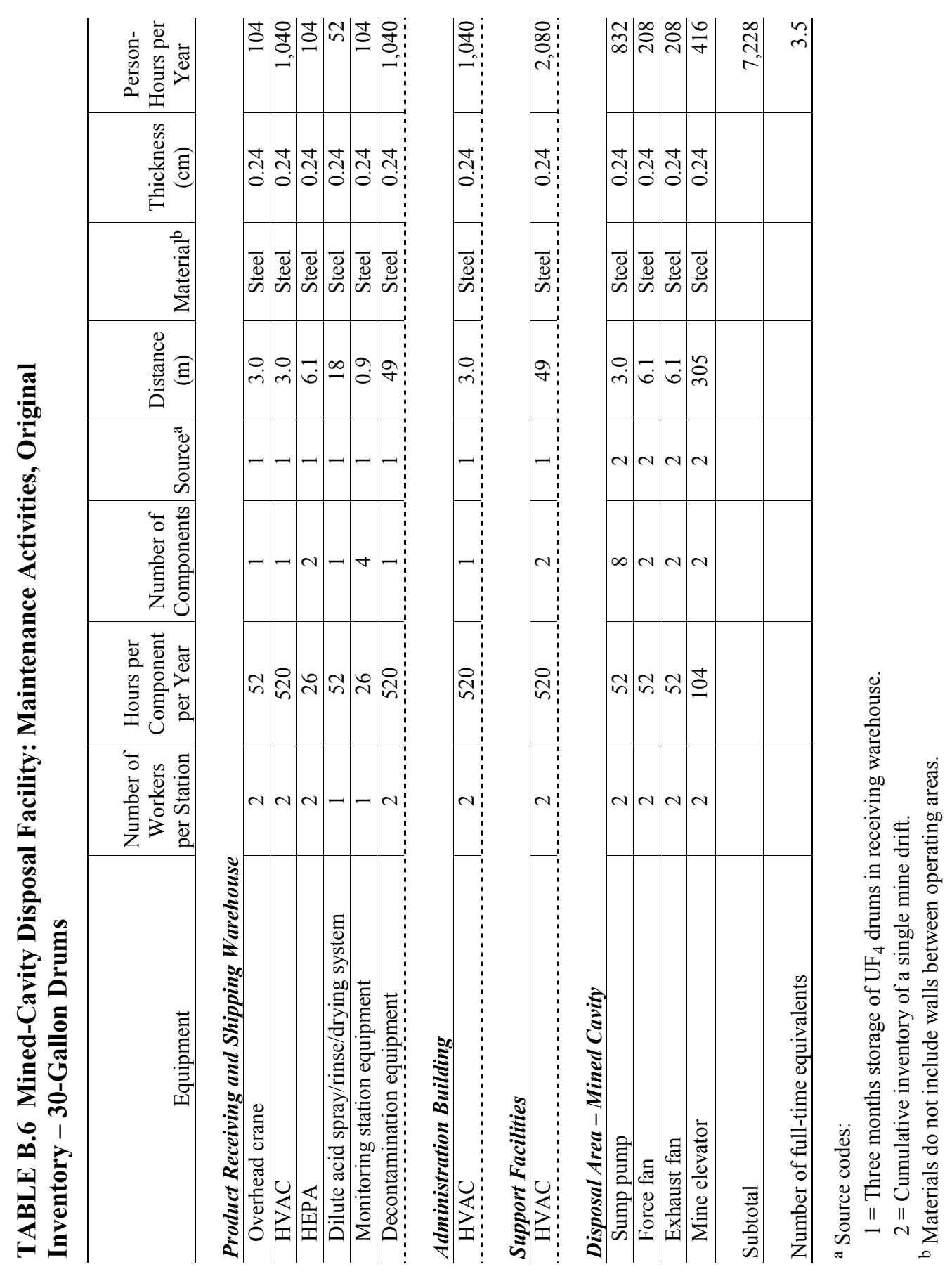




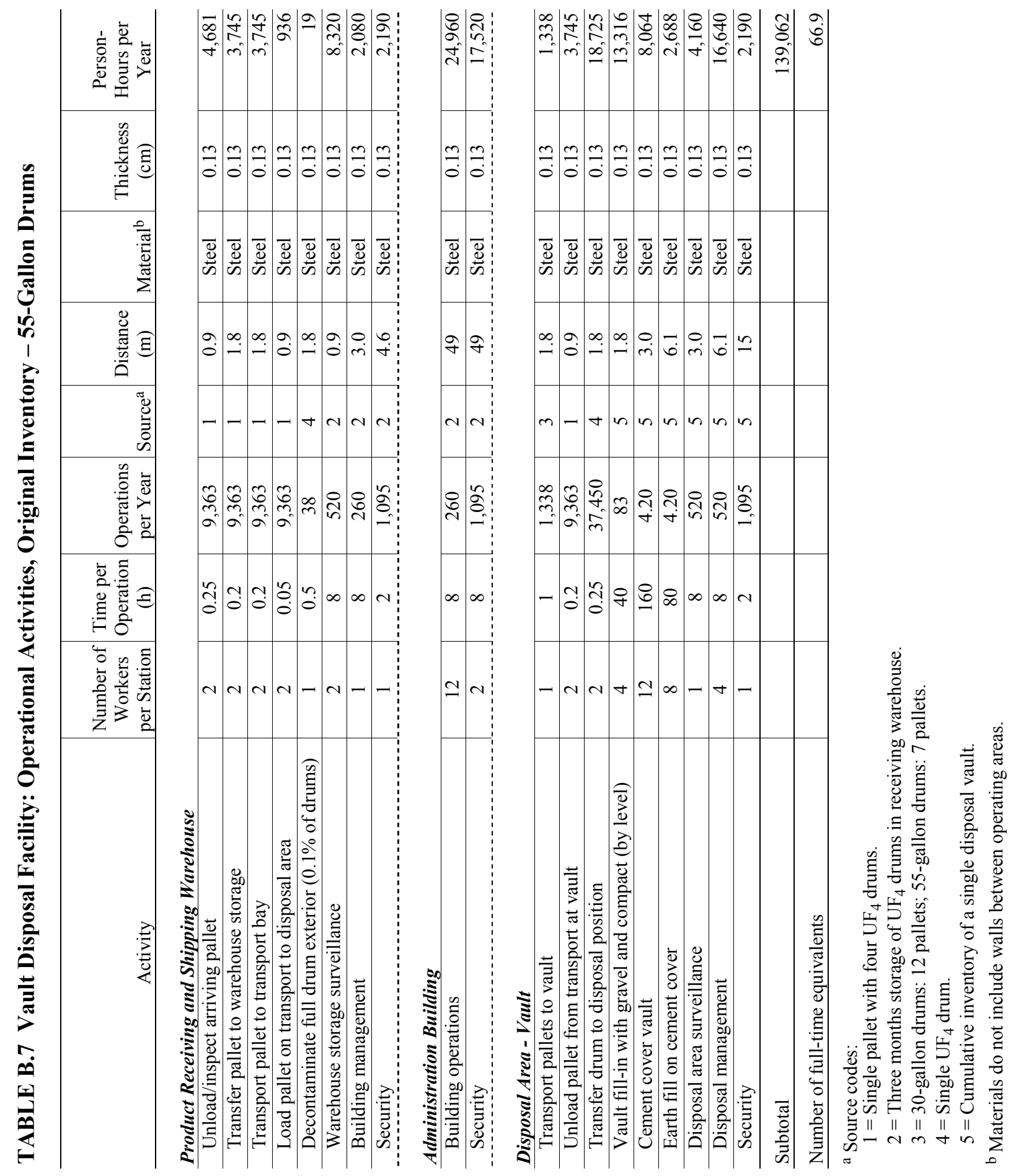




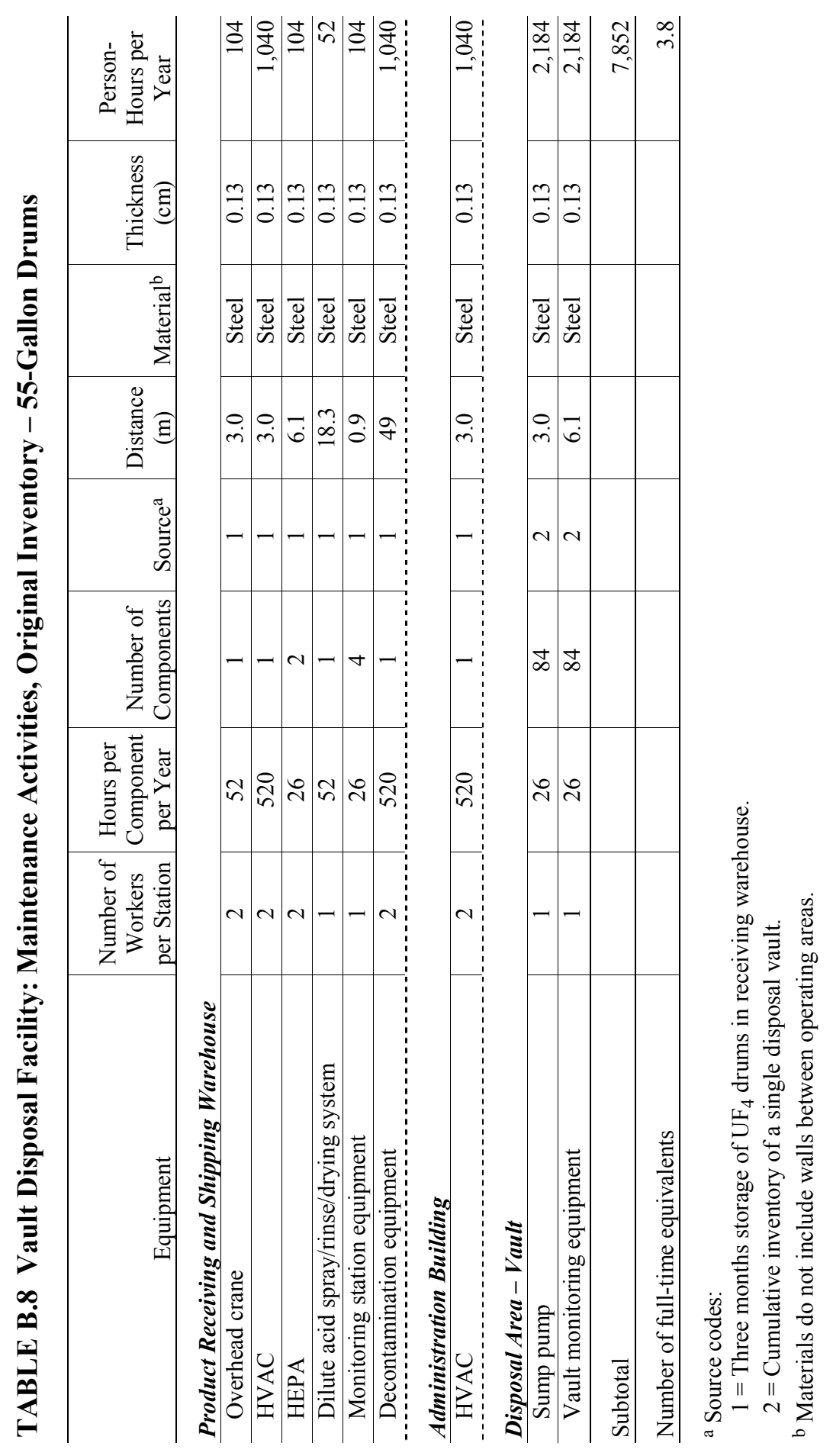




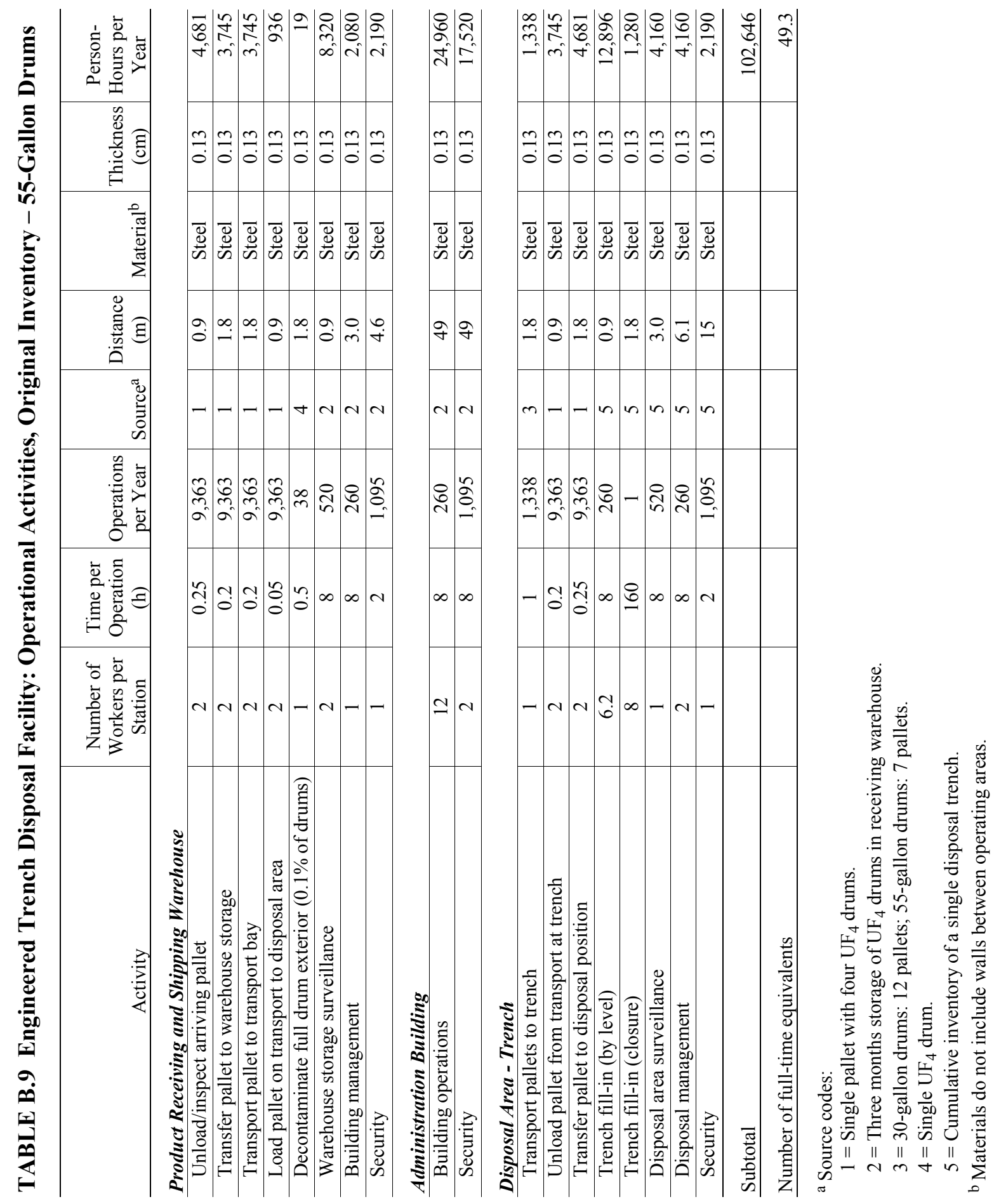




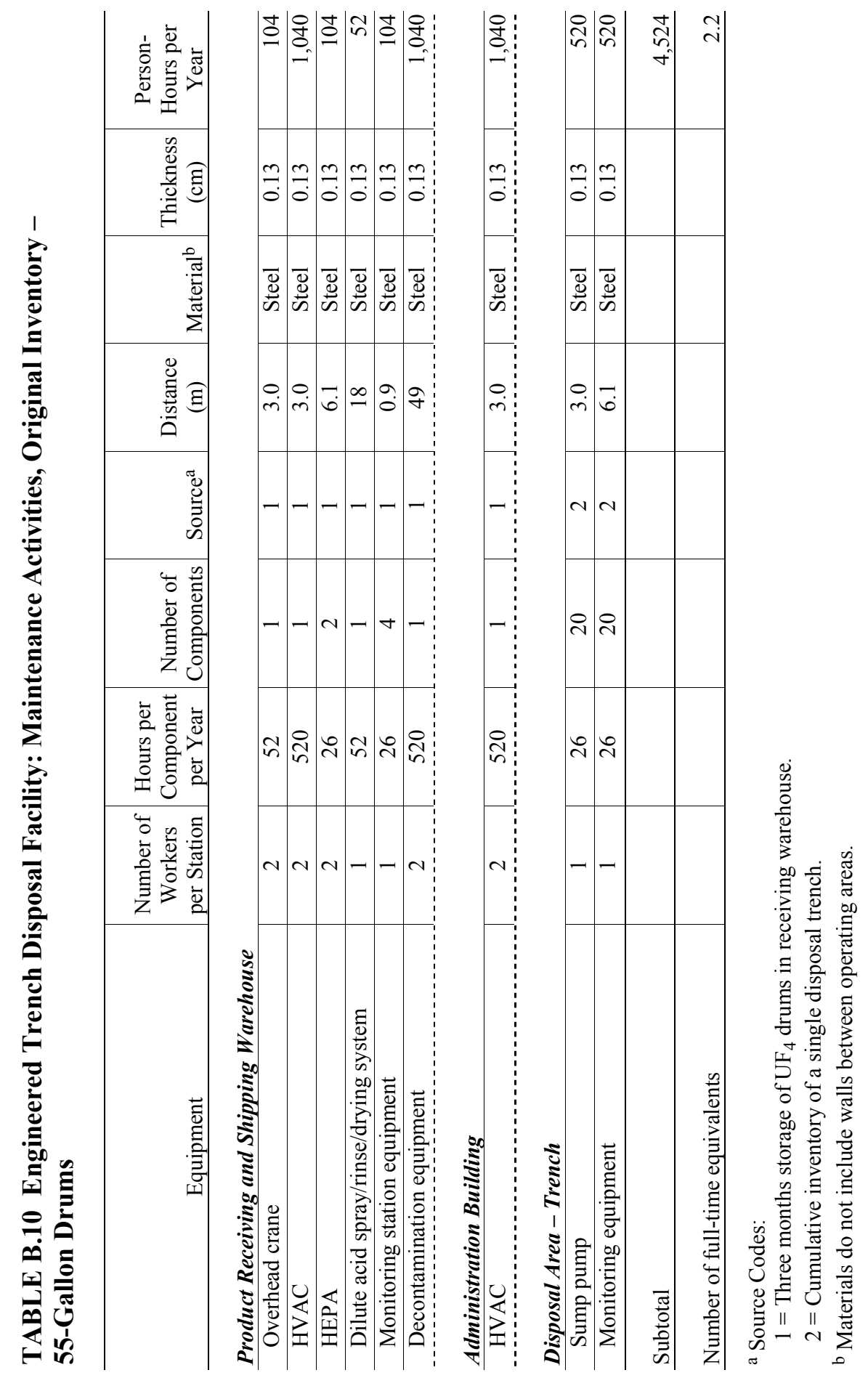




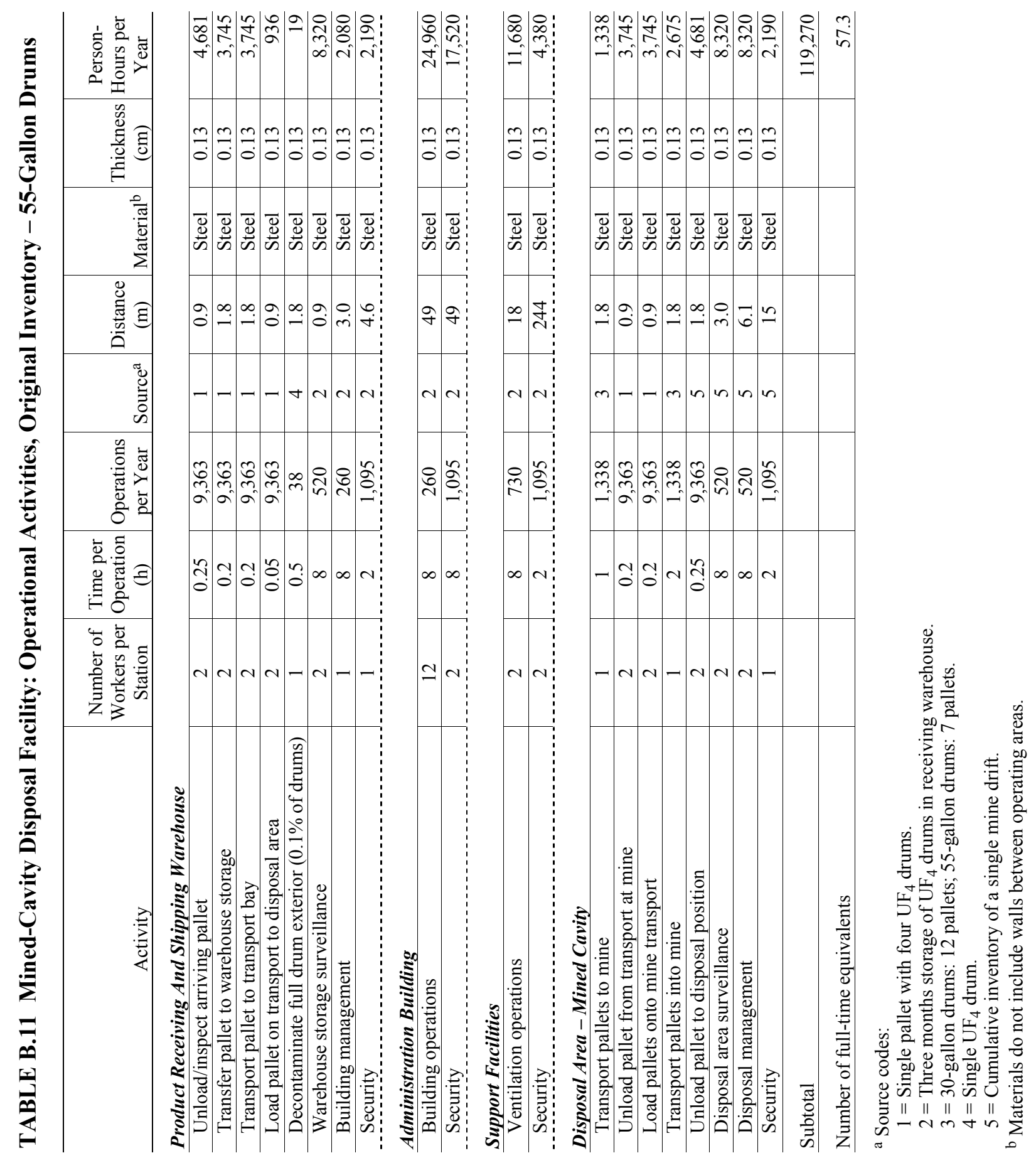




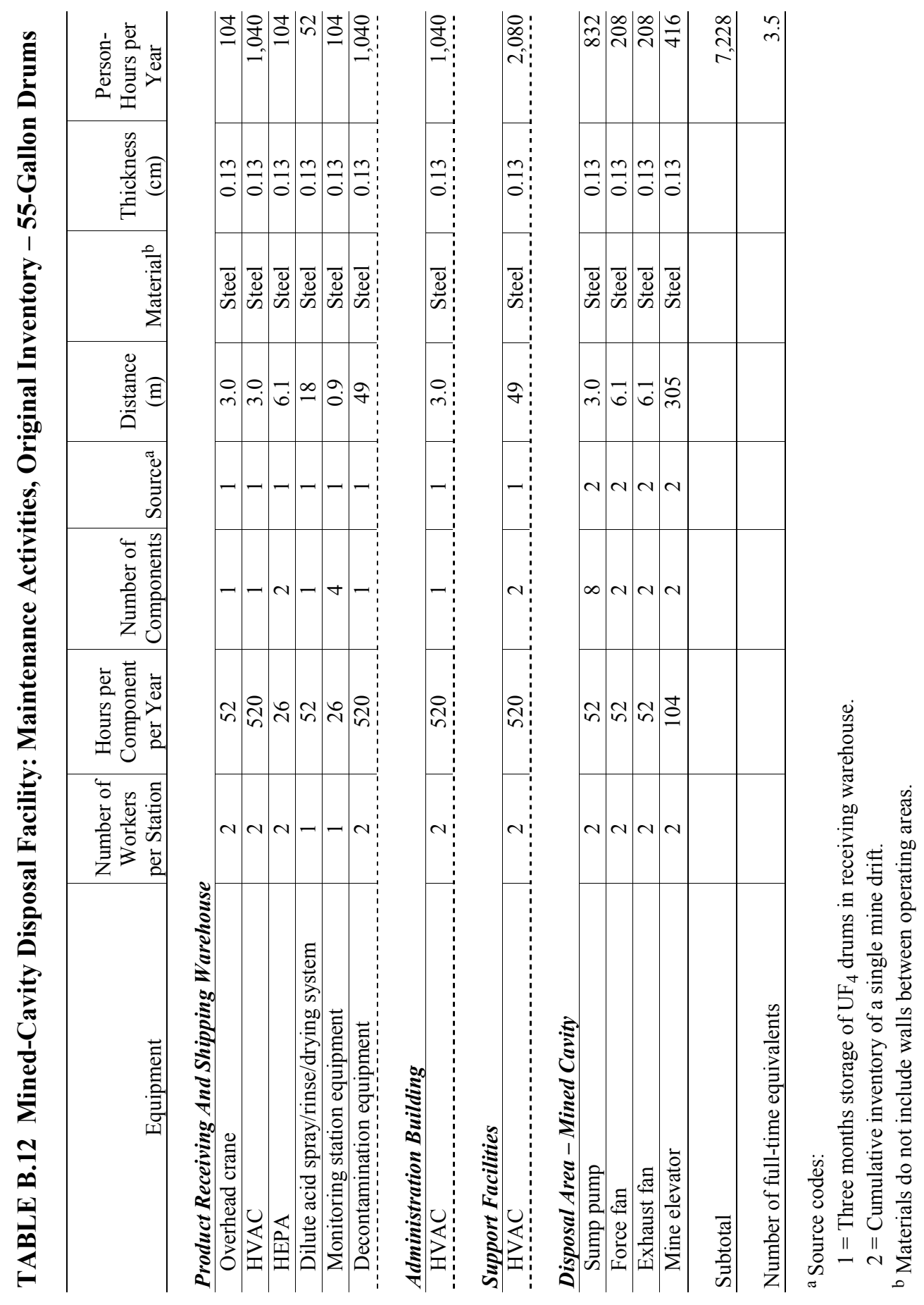




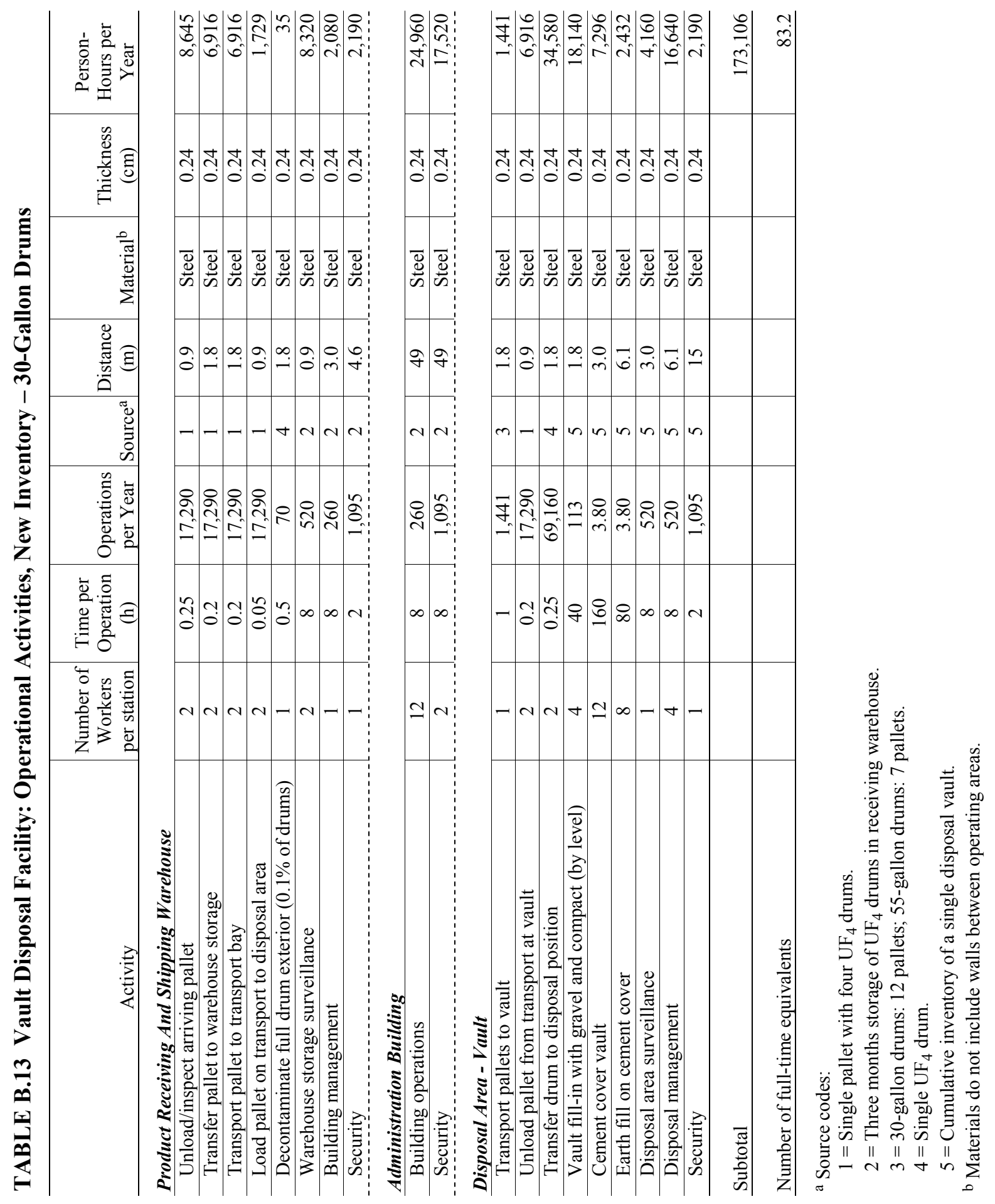




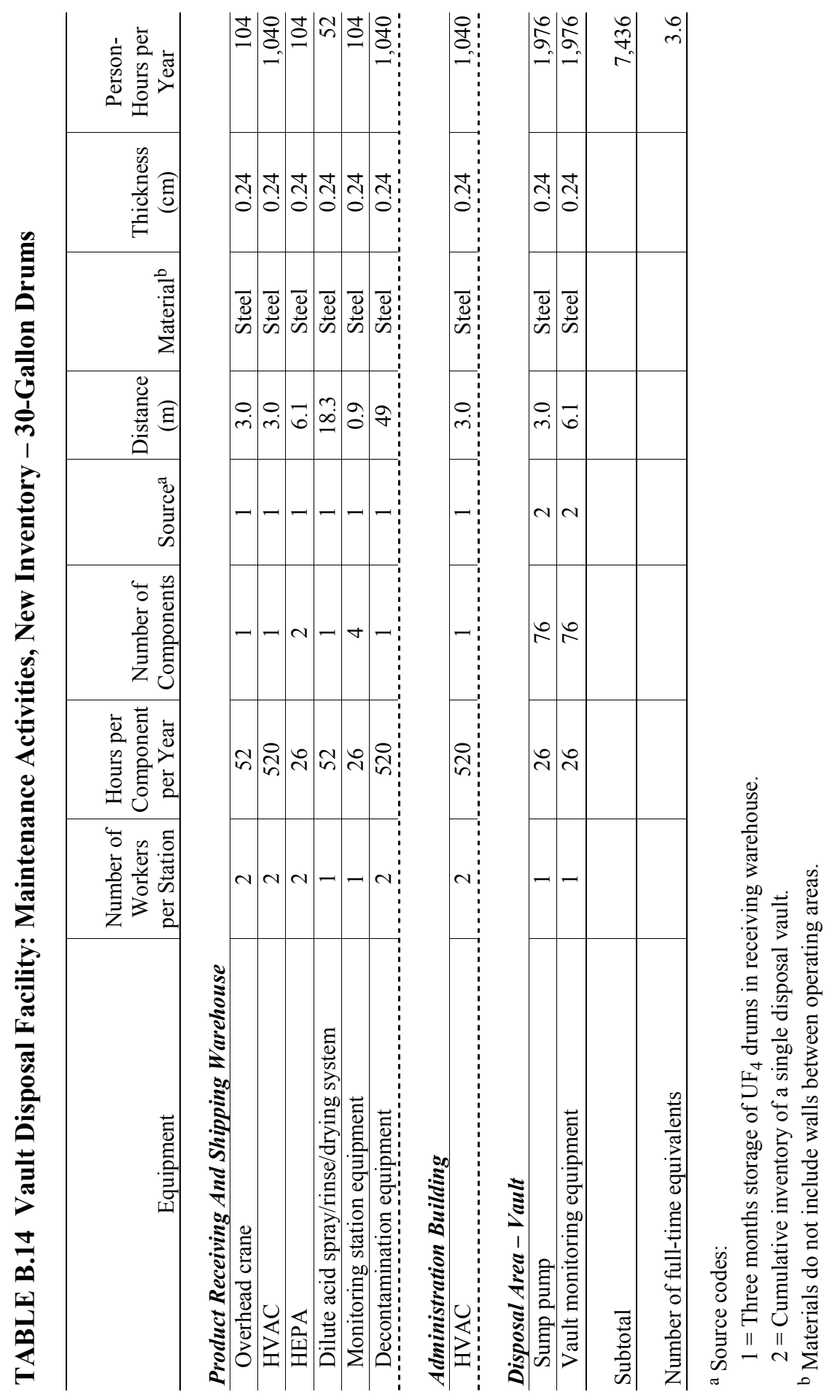




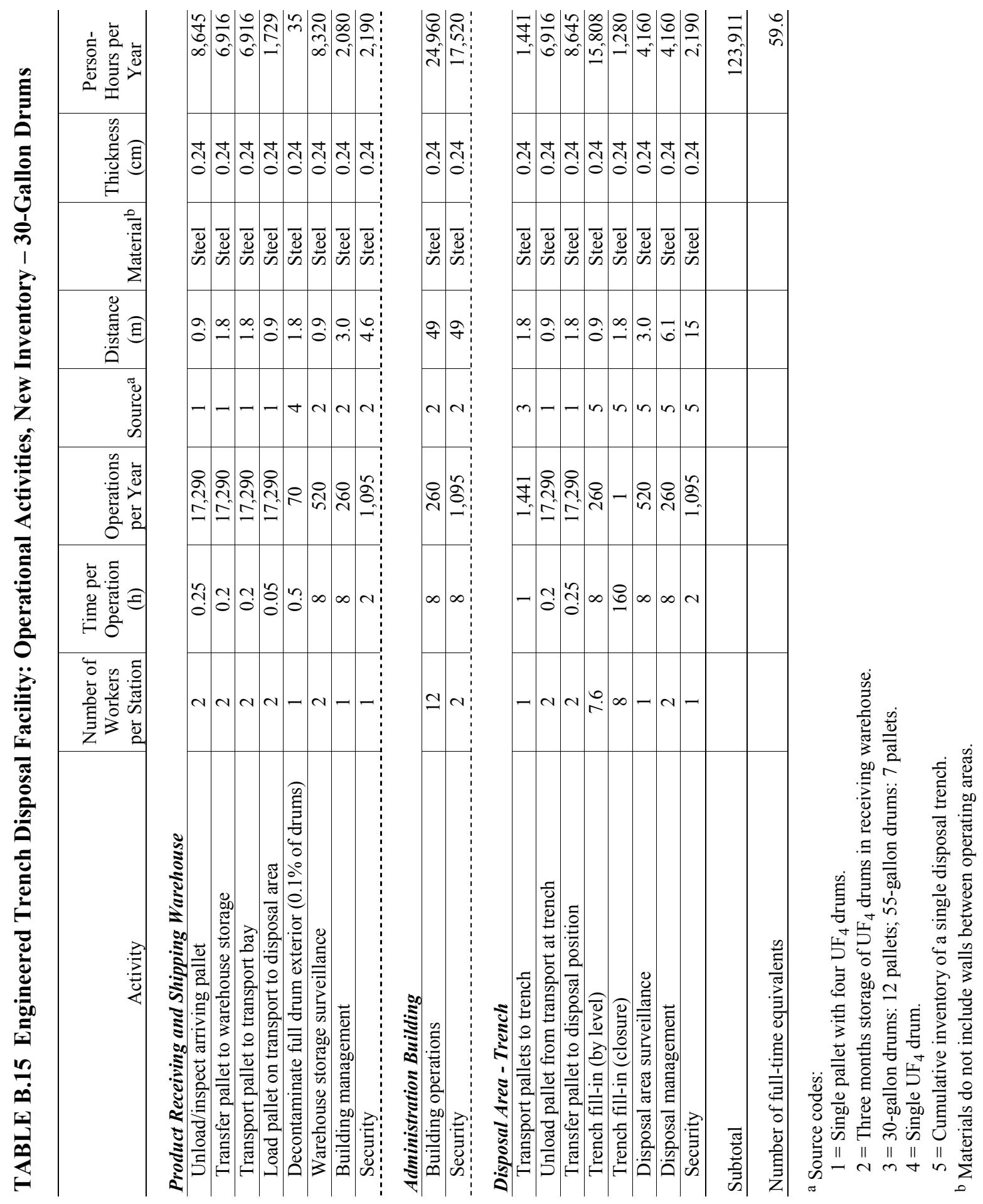




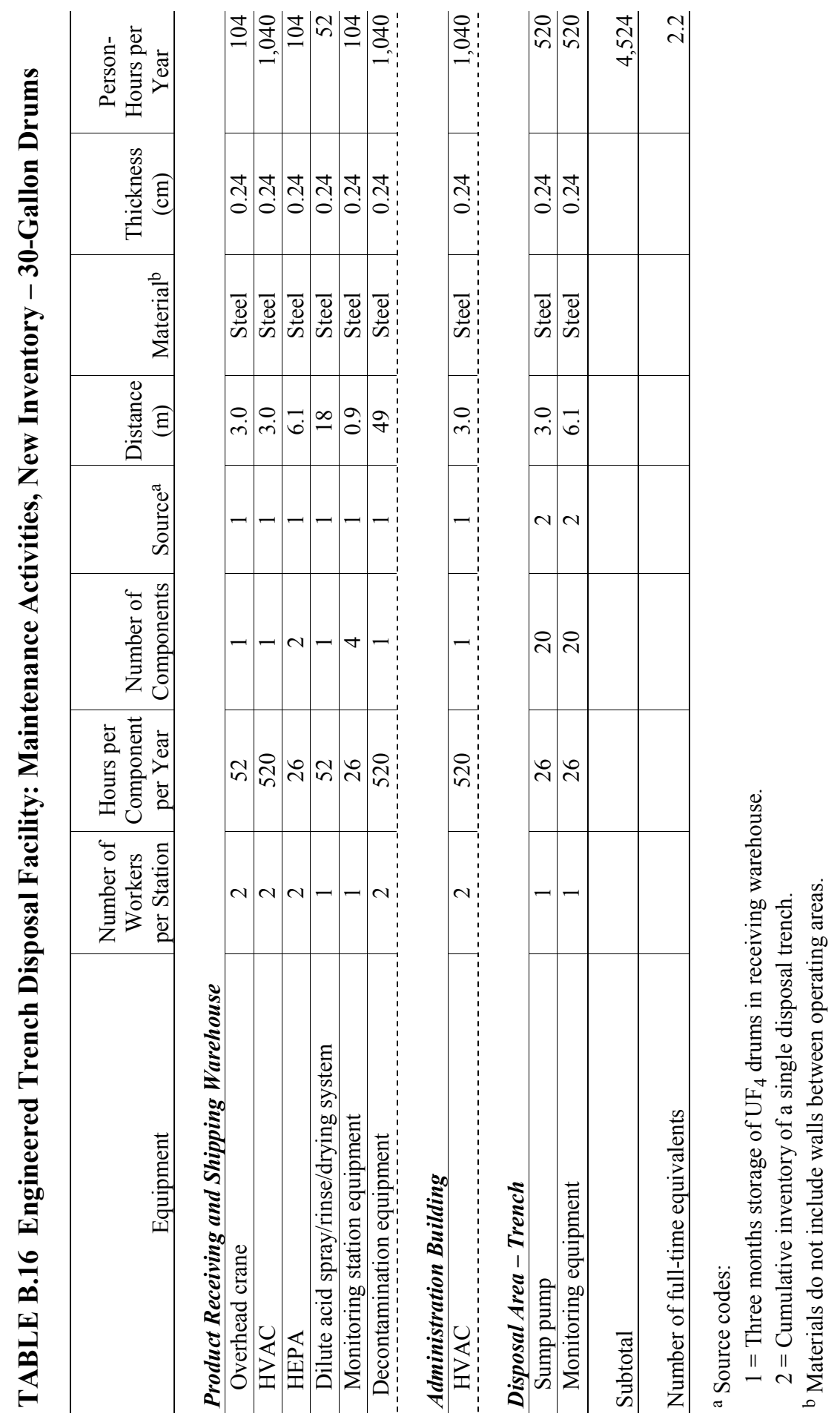




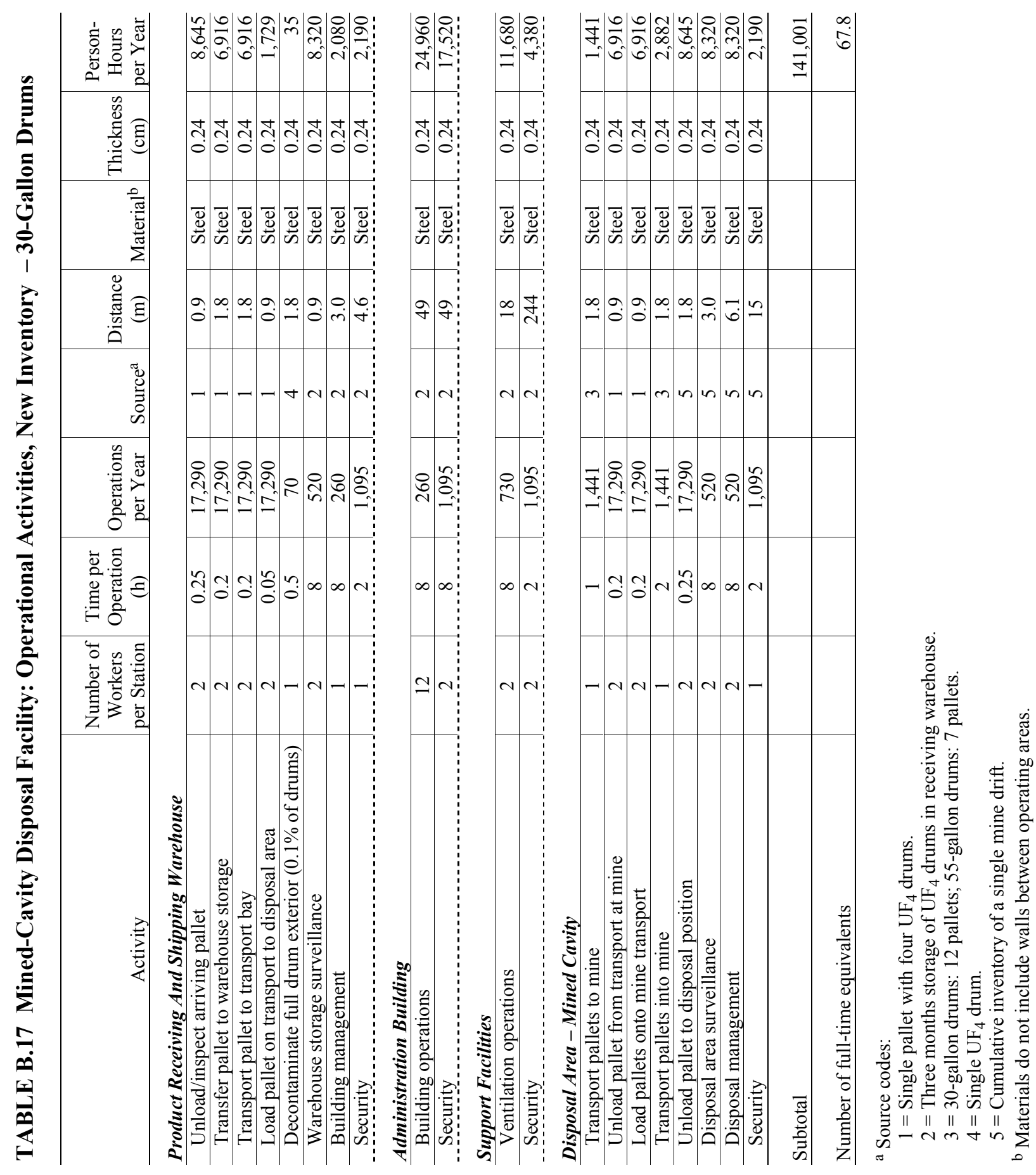




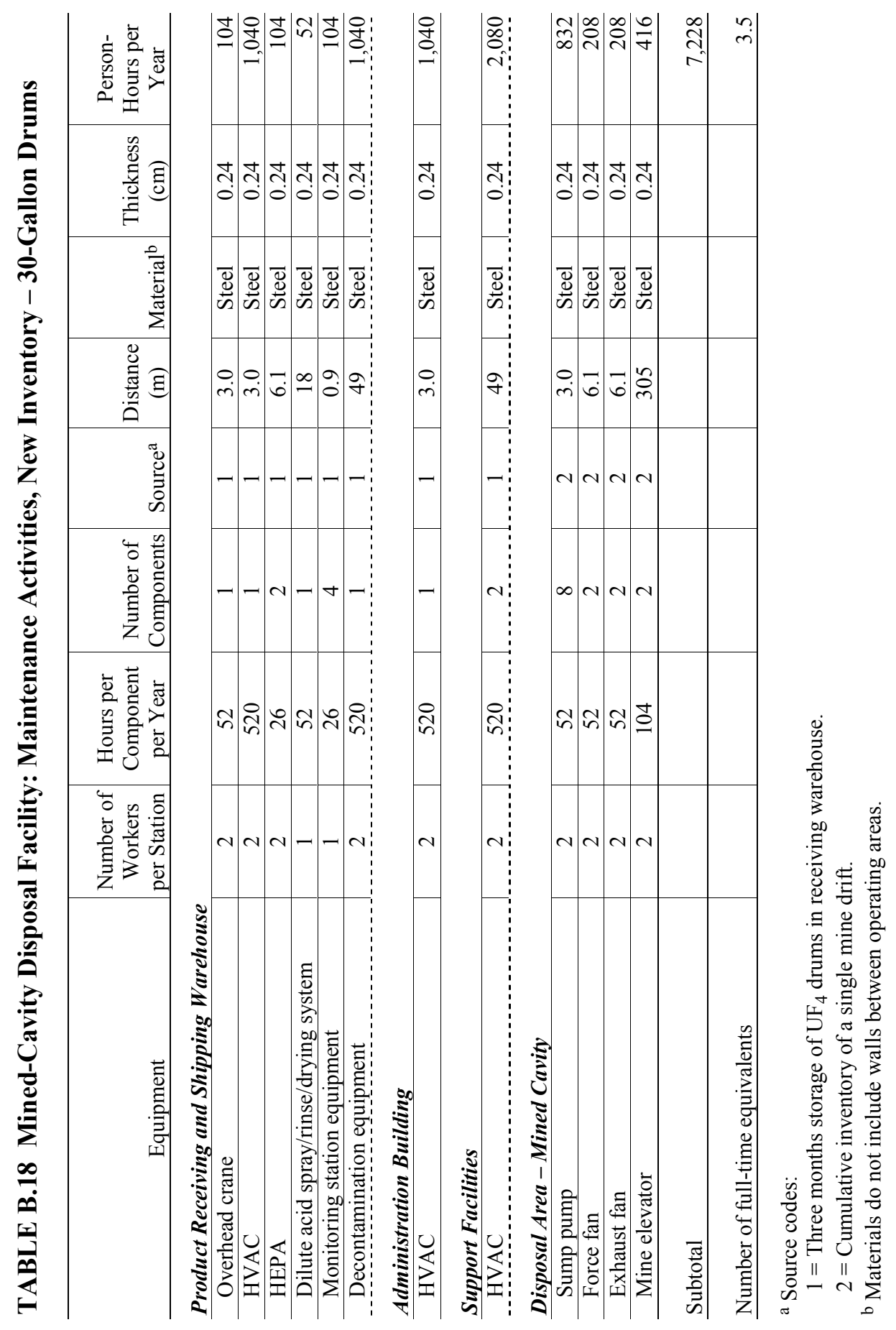




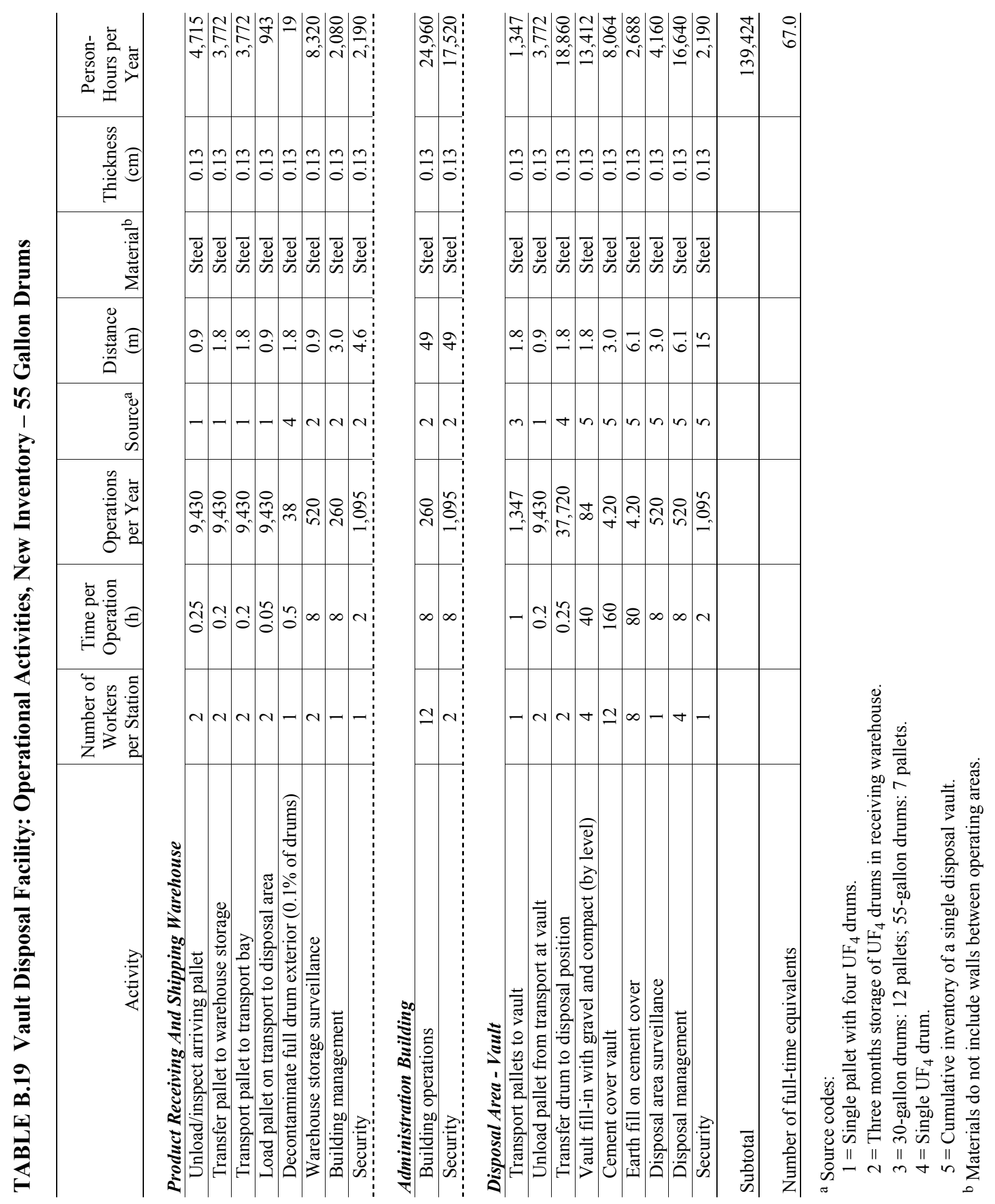




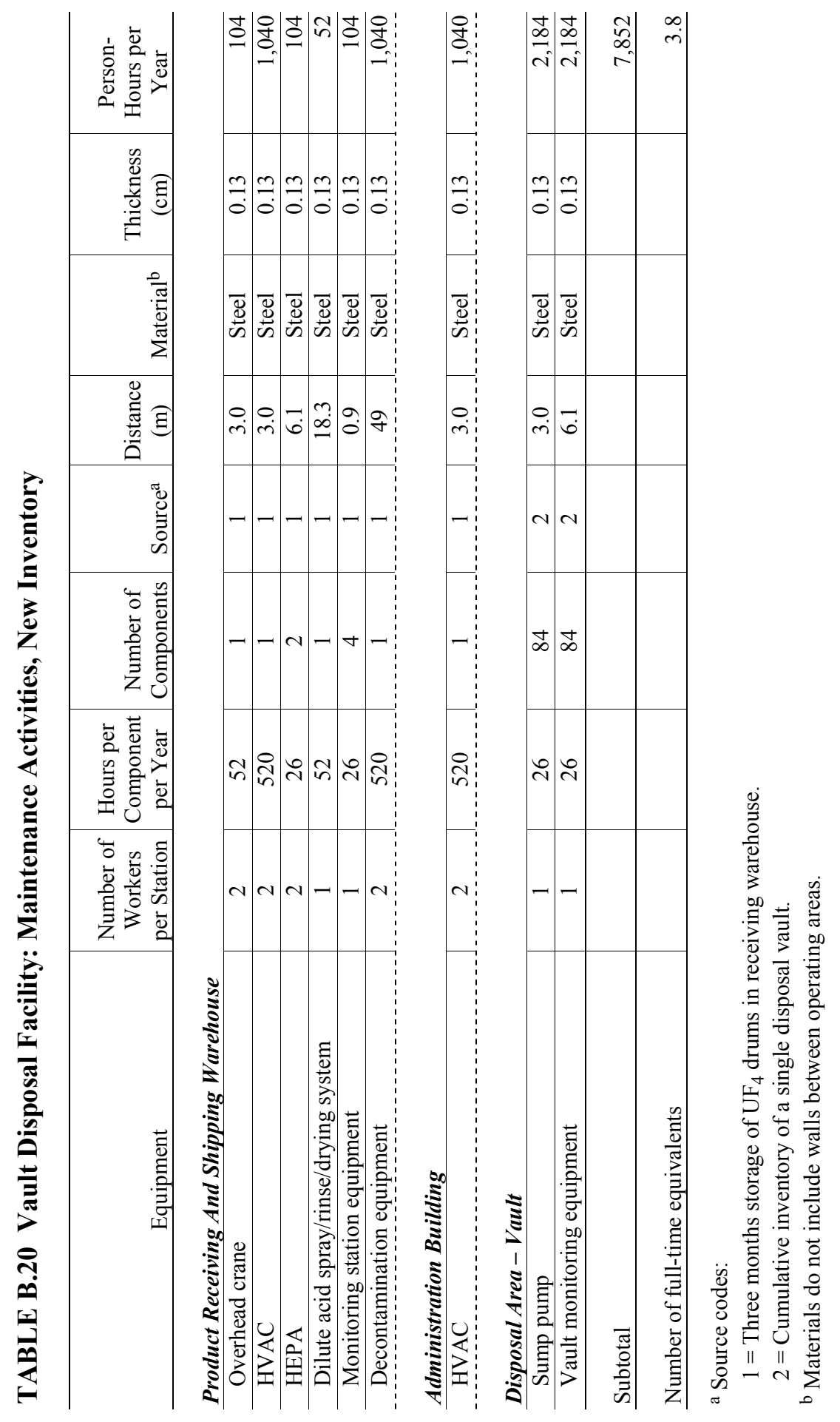




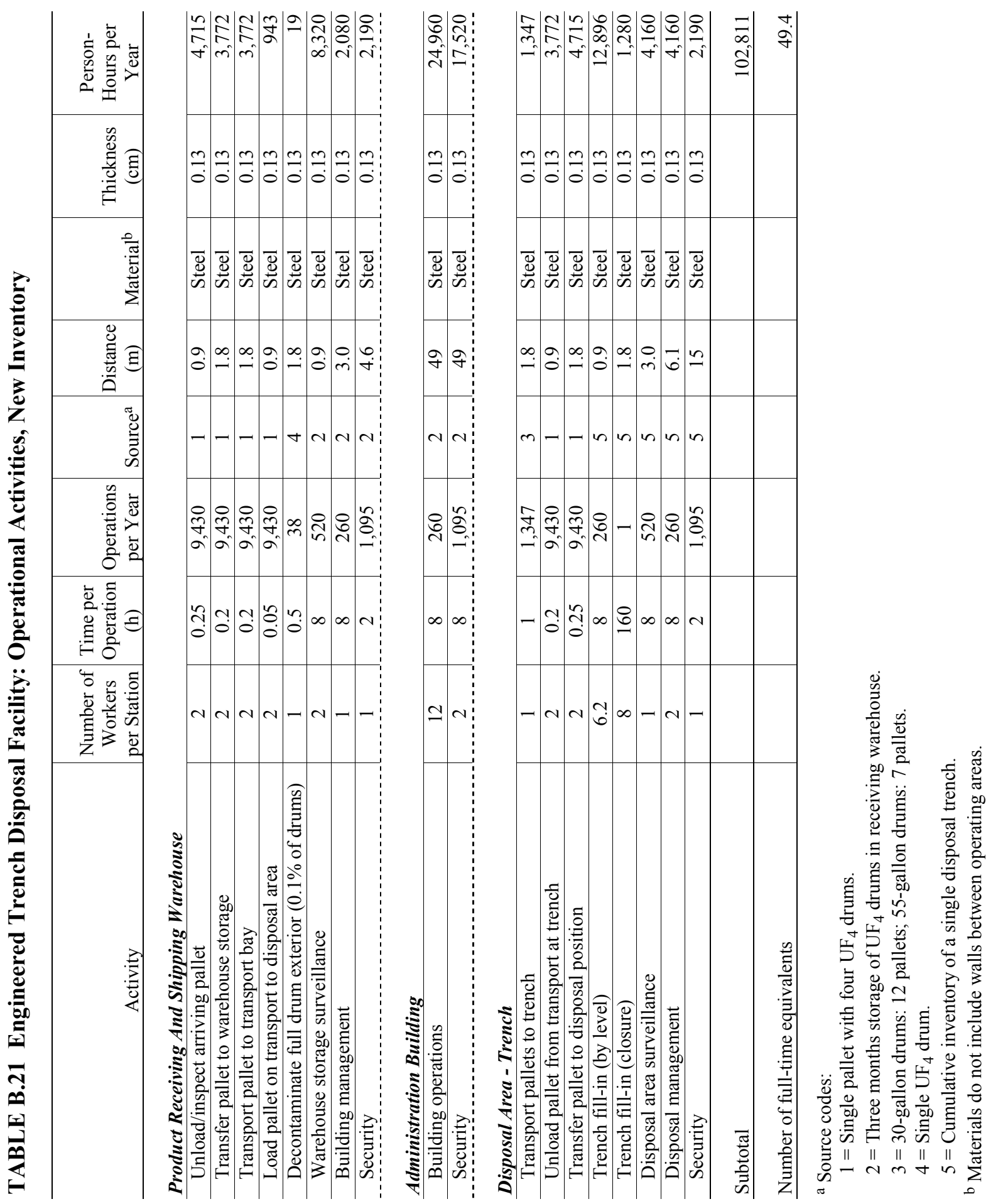




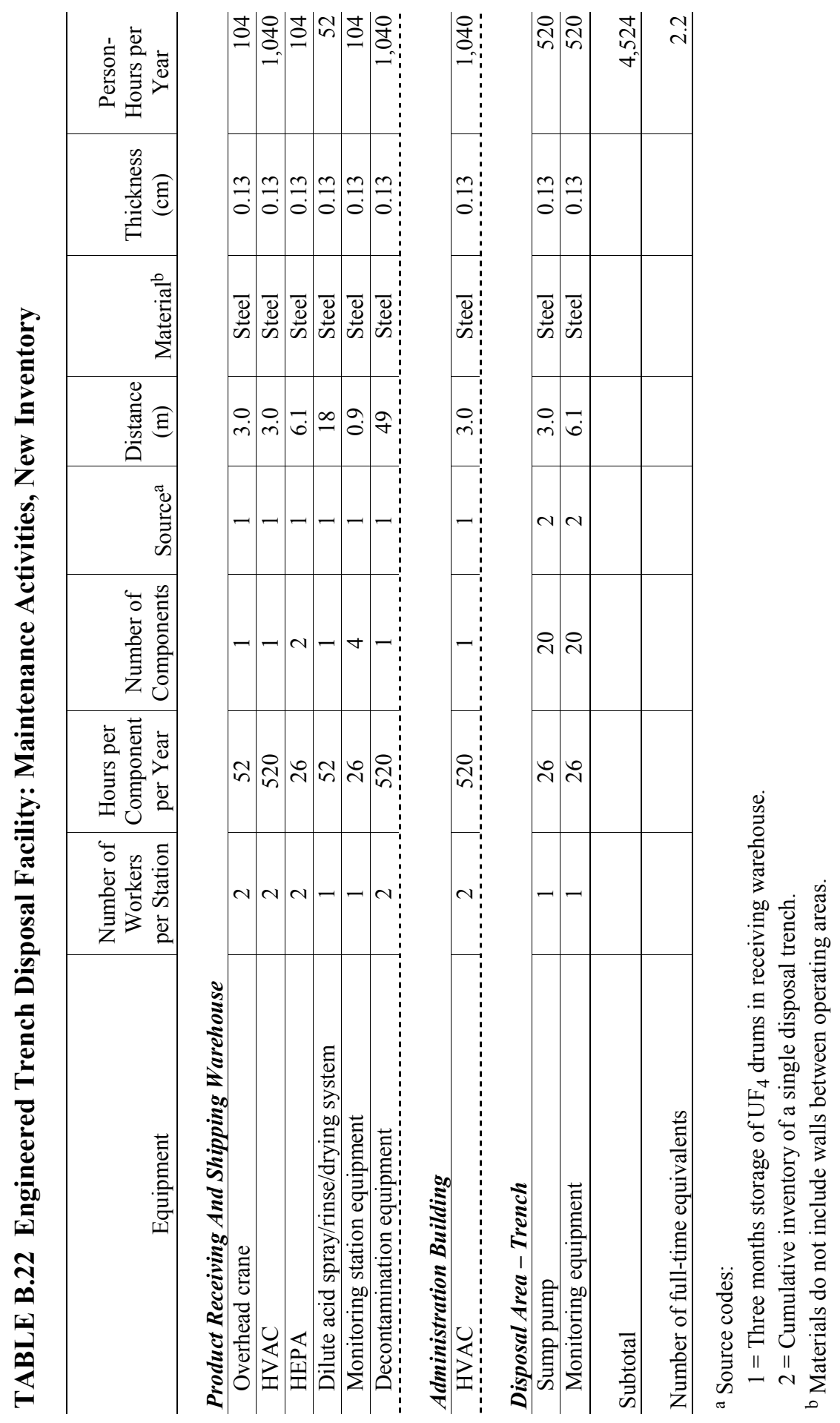




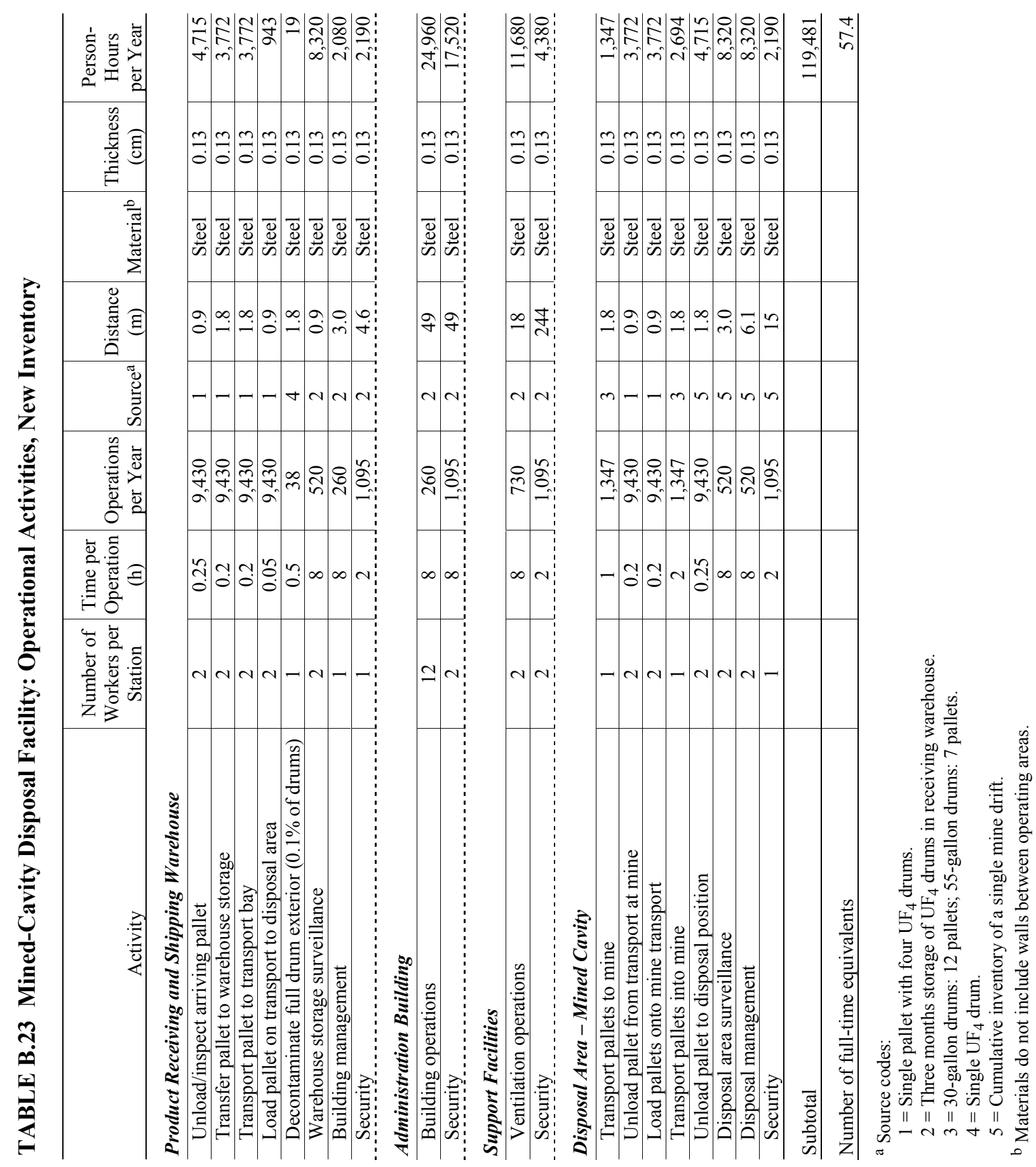




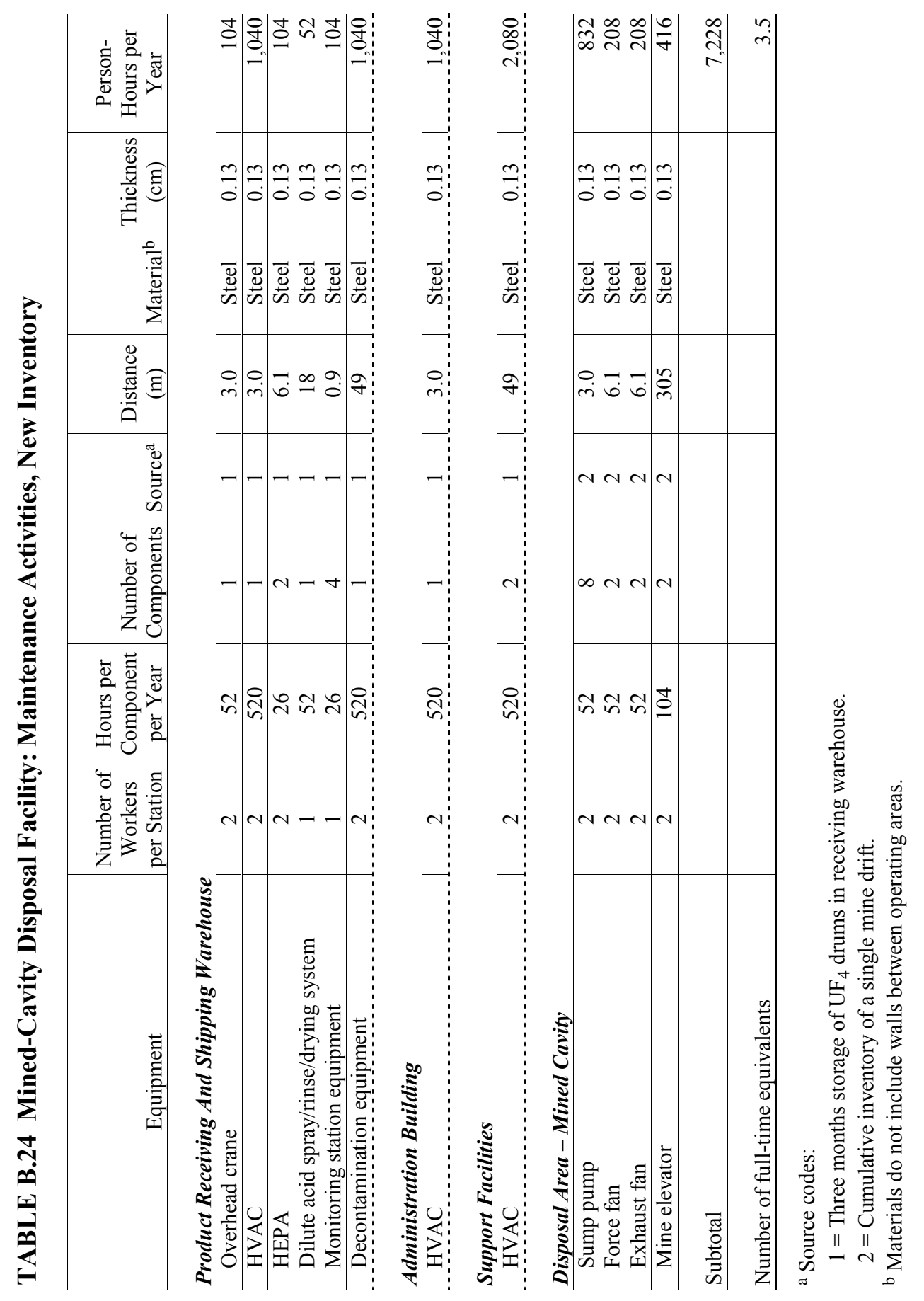




$$
\text { C-2 }
$$


C-3

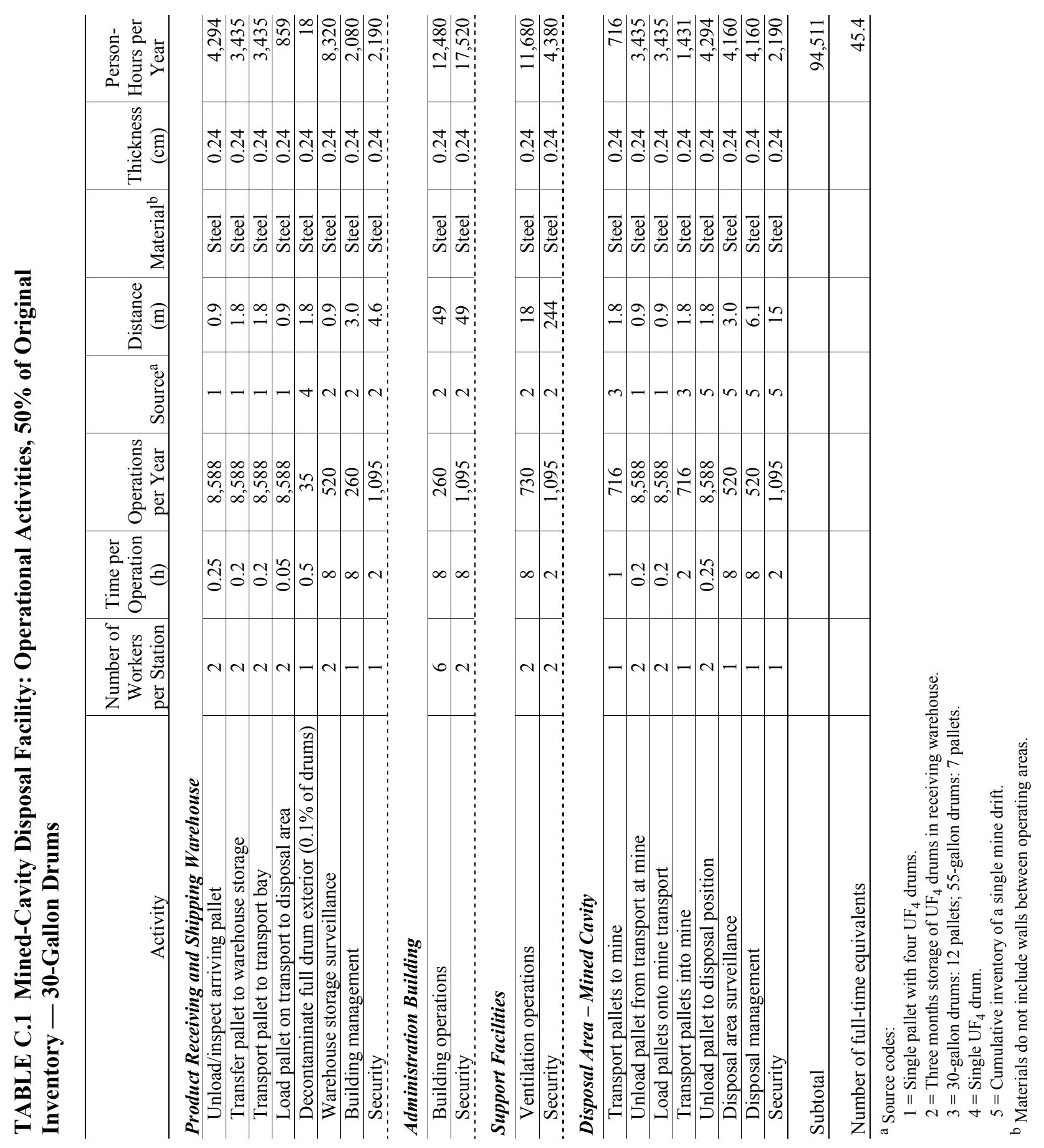


C-4

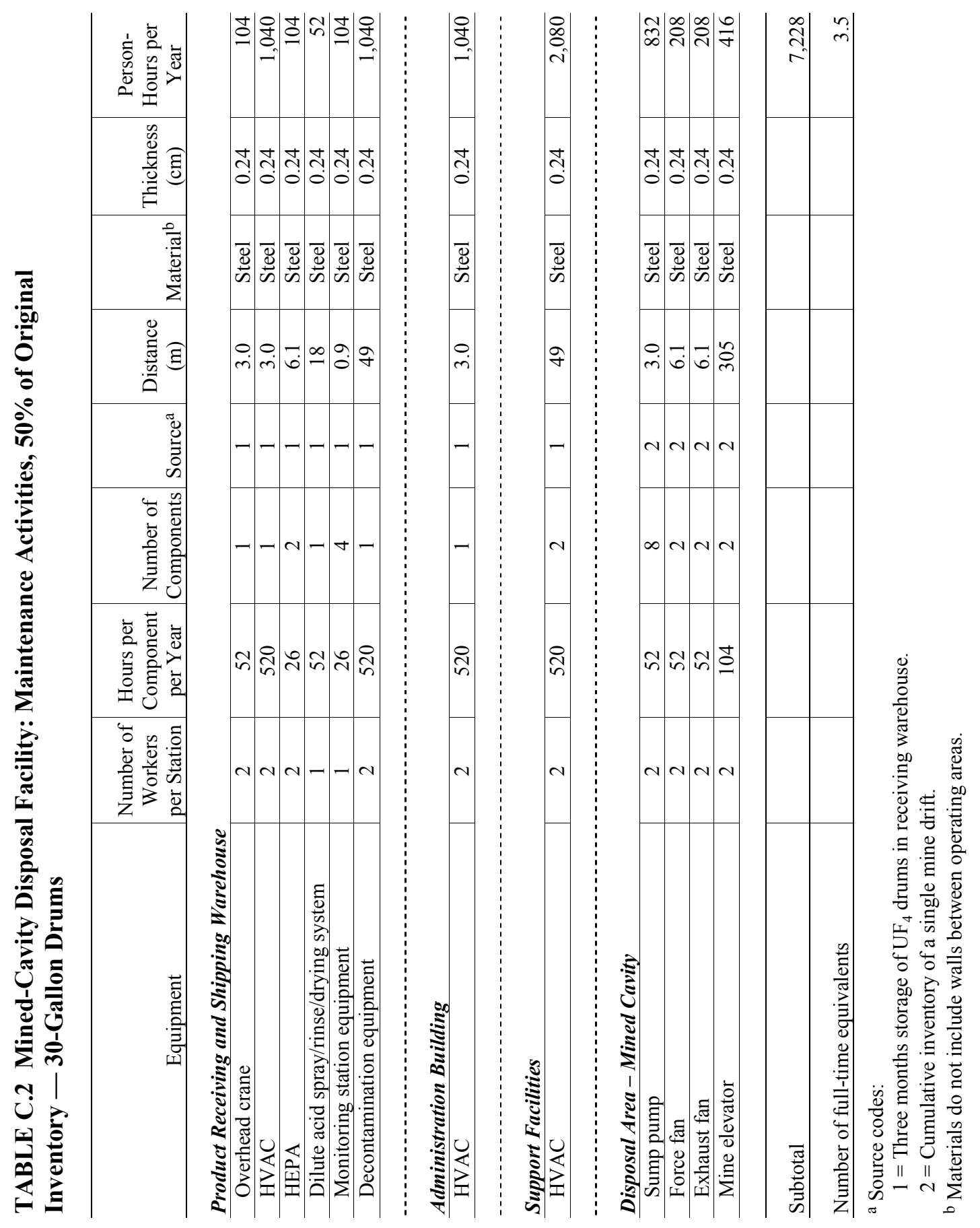




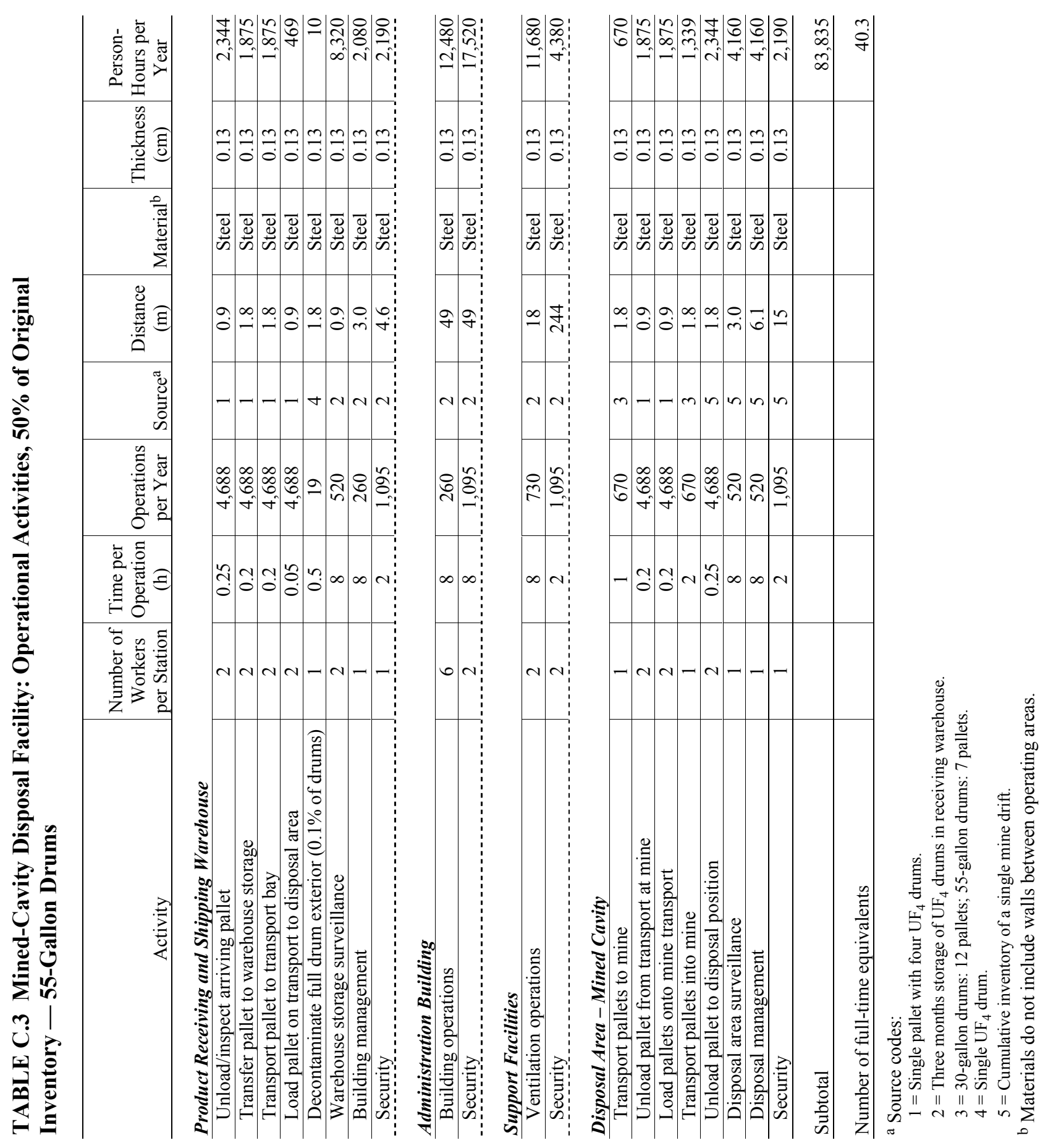


C-6

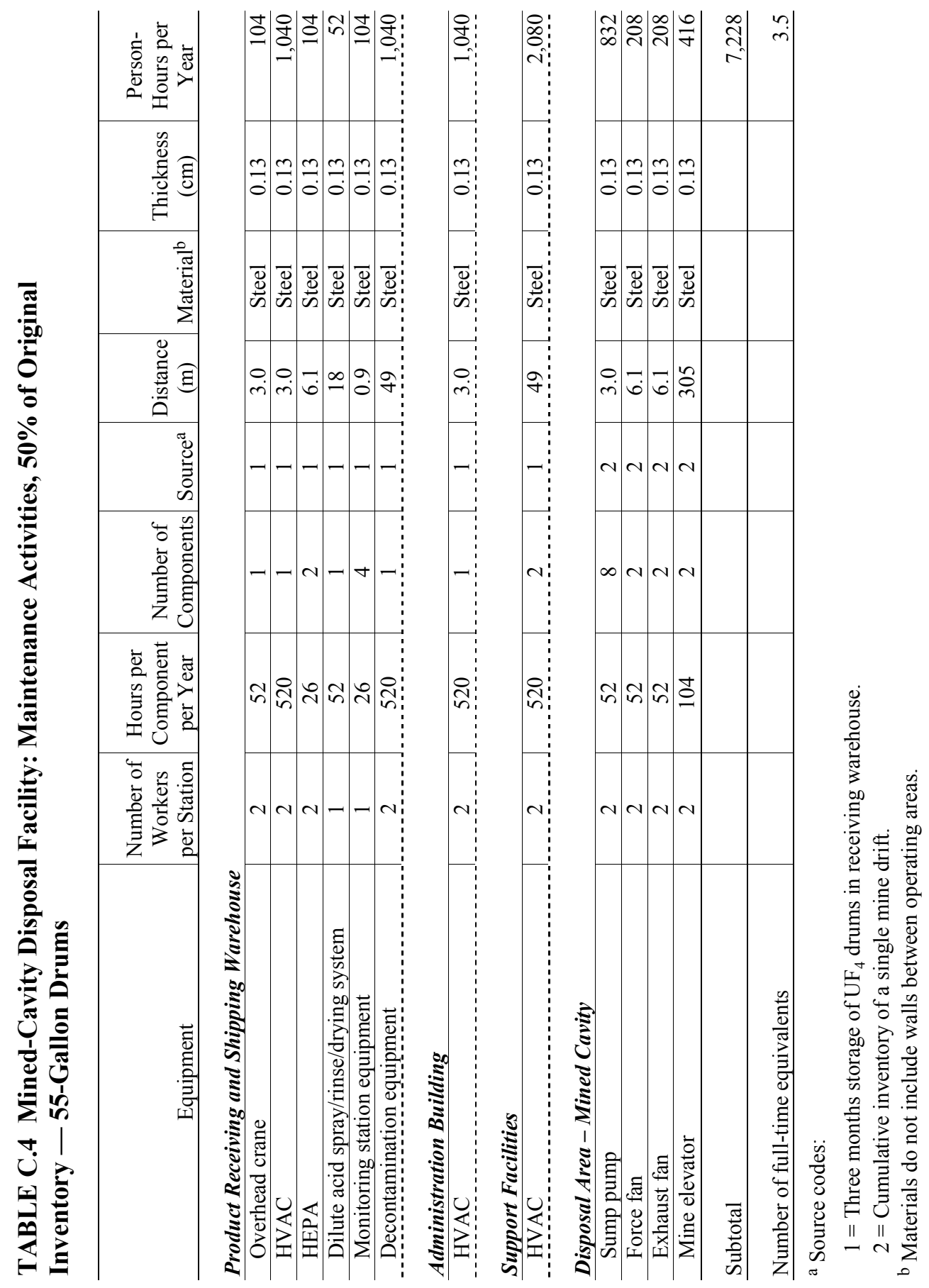


C-7

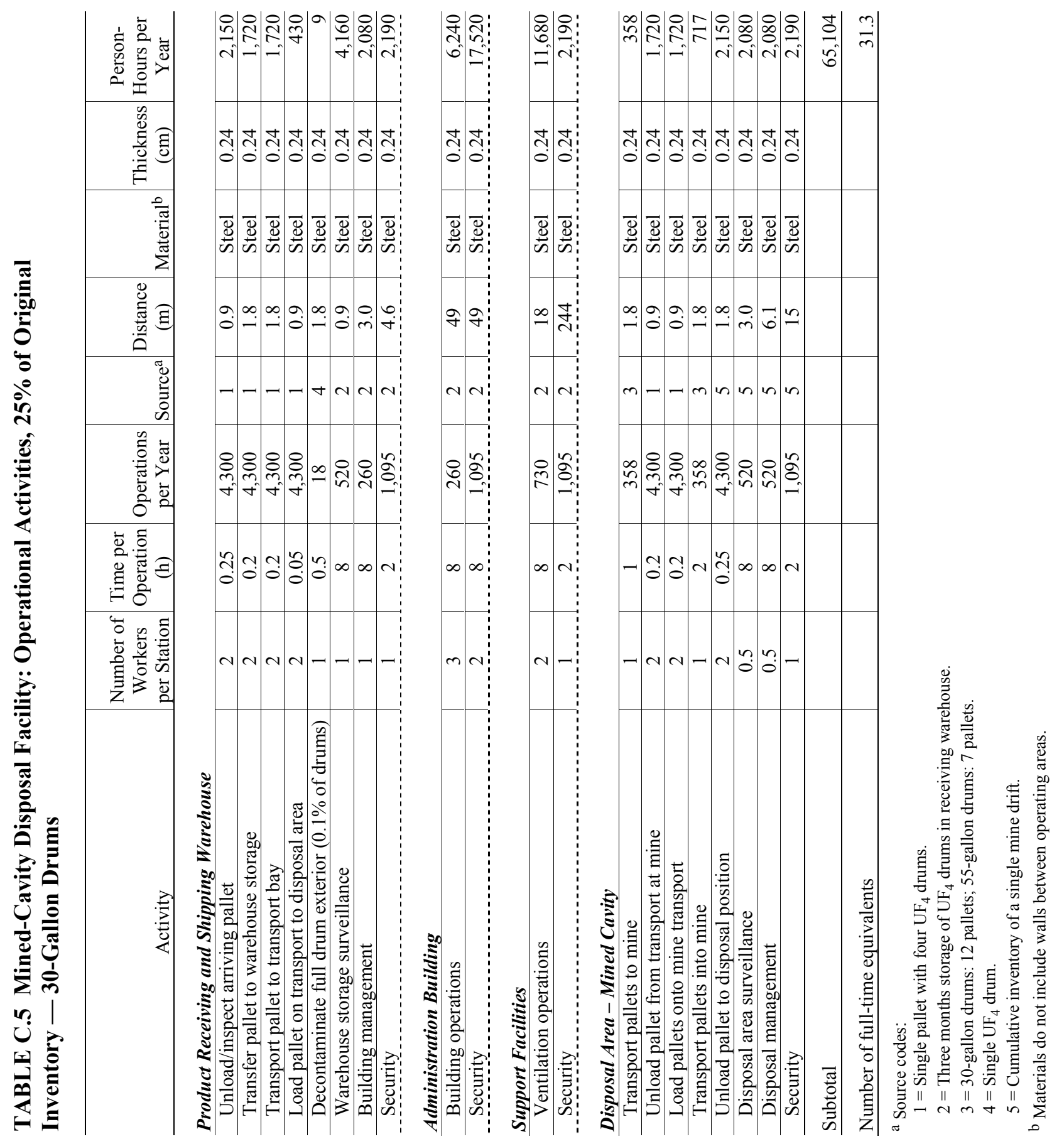


C-8

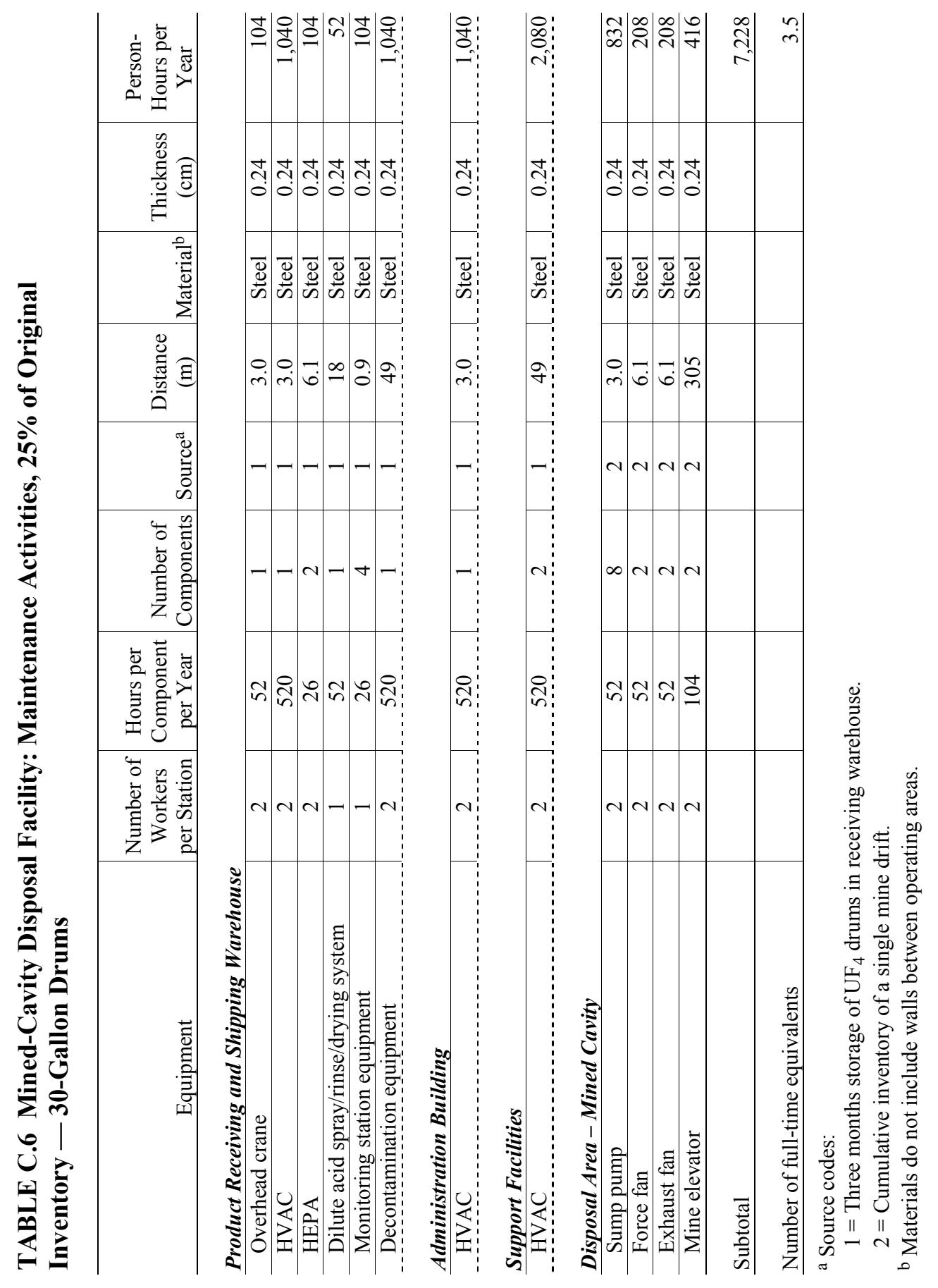




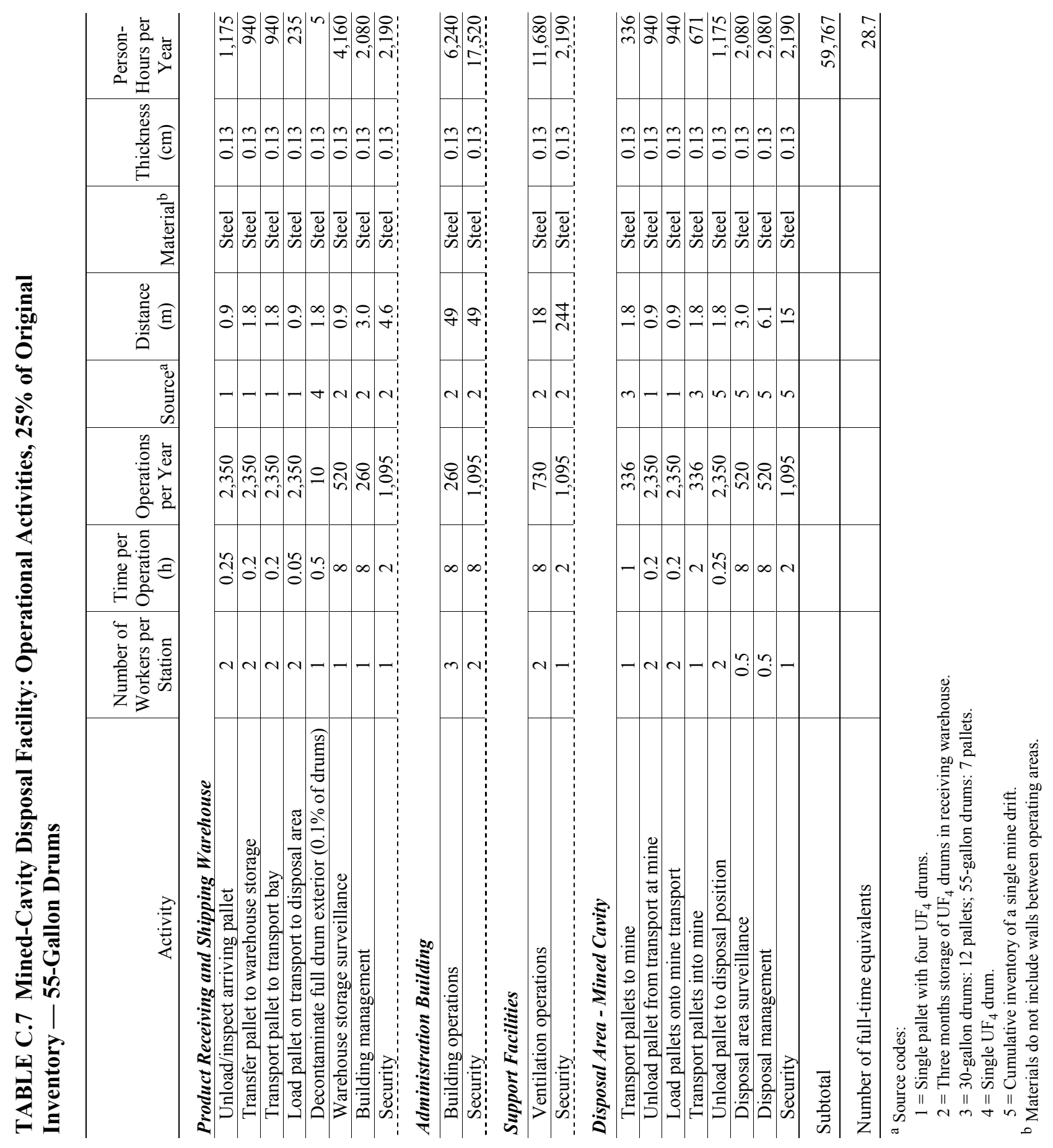




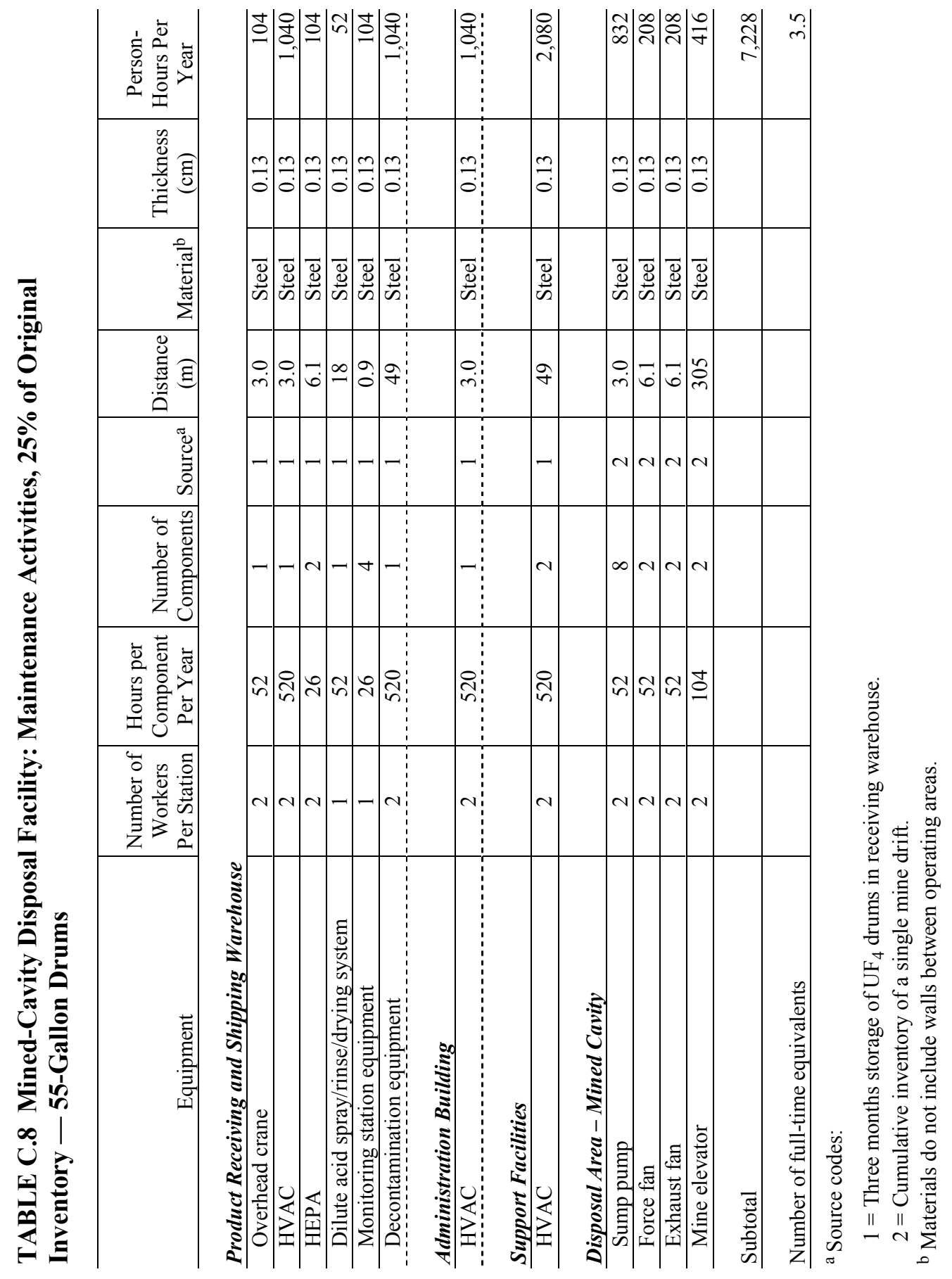

